Prepared in cooperation with the U.S. National Park Service

The Source, Discharge, and Chemical Characteristics of Selected Springs, and the Abundance and Health of Associated Endemic Anuran Species in the Mojave Network Parks

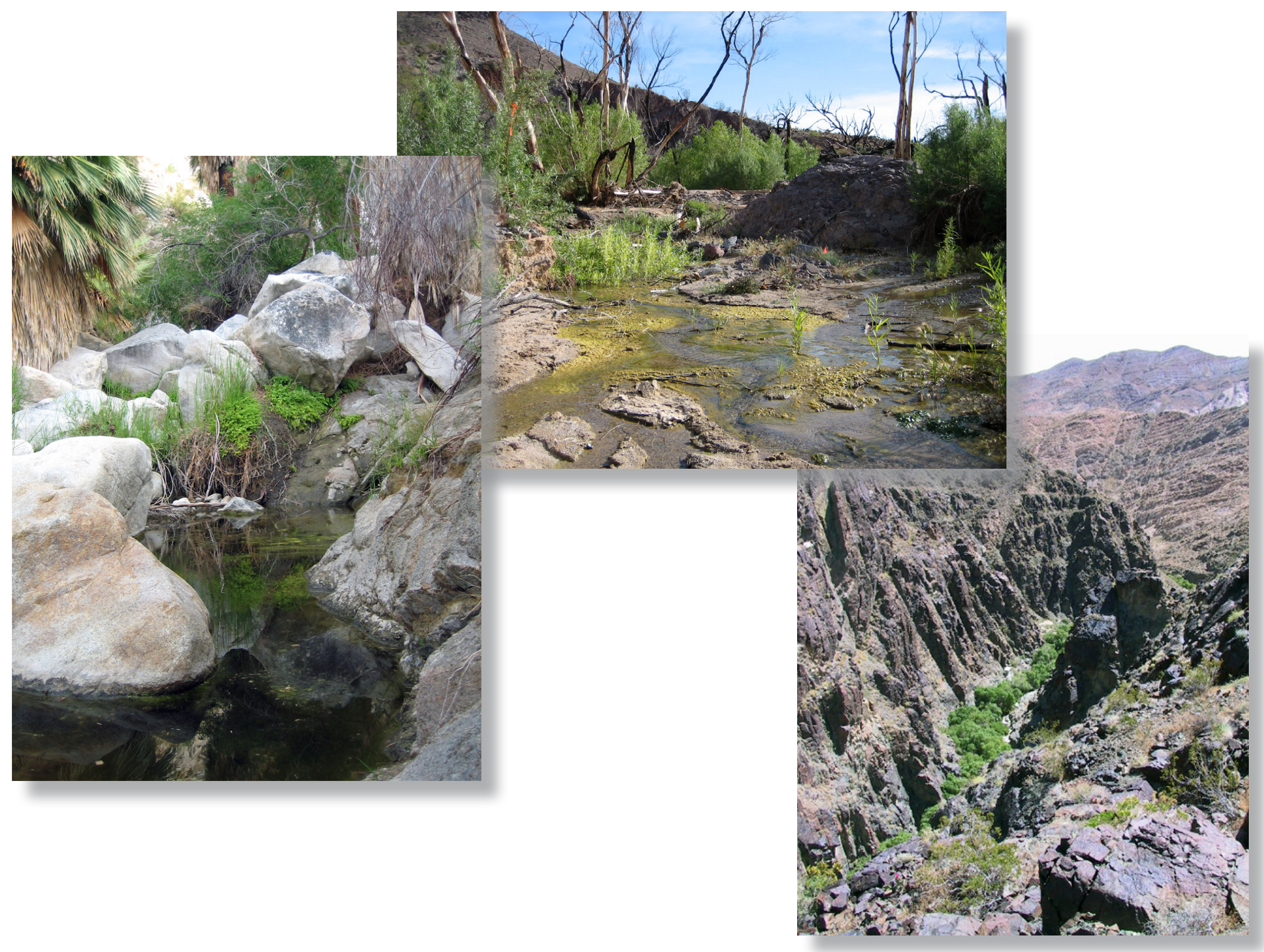

Scientific Investigations Report 2015-5027 


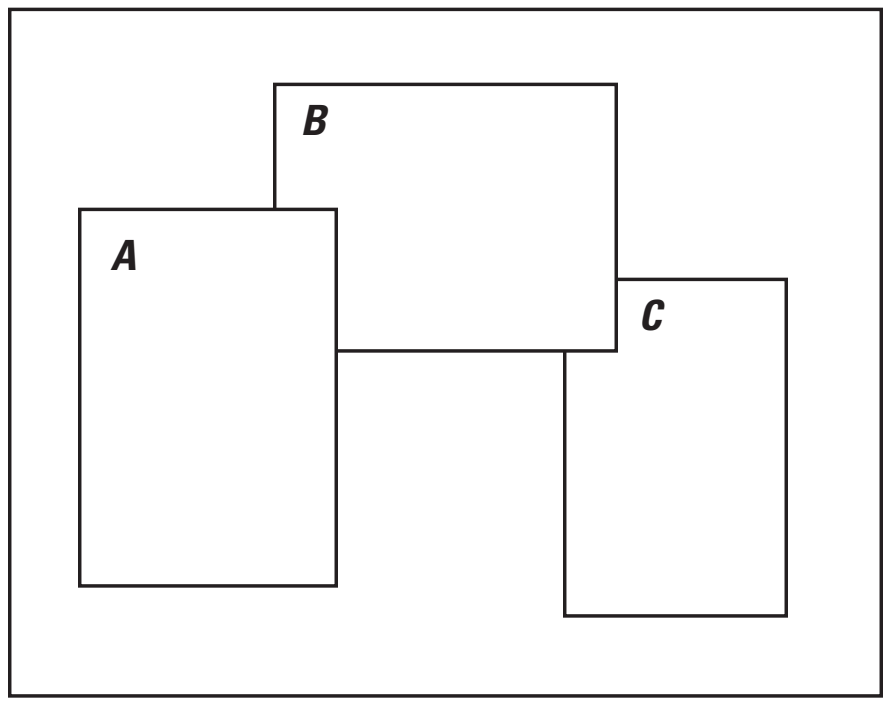

Cover. A. View of a pool in the Fortynine Palms Oasis, Joshua Tree National Monument, Calif. B. View of Piute Creek in the Mojave National Reserve, Calif. C. Looking down Darwin Canyon towards Darwin Falls, Death Valley National Park, Calif. All photographs by Elizabeth Gallegos, U.S. Geological Survey. 


\section{The Source, Discharge, and Chemical Characteristics of Selected Springs, and the Abundance and Health of Associated Endemic Anuran Species in the Mojave Network Parks}

Compiled by Peter Martin and Roy A. Schroeder

With chapters by Roy A. Schroeder, Gregory A. Smith, Peter Martin, Alan L. Flint, Elizabeth Gallegos, and Robert N. Fisher

Prepared in cooperation with the U.S. National Park Service

Scientific Investigations Report 2015-5027 


\section{U.S. Department of the Interior \\ SALLY JEWELL, Secretary}

\section{U.S. Geological Survey \\ Suzette M. Kimball, Acting Director}

\section{U.S. Geological Survey, Reston, Virginia: 2015}

For more information on the USGS - the Federal source for science about the Earth, its natural and living resources, natural hazards, and the environment—visit http://www.usgs.gov or call 1-888-ASK-USGS.

For an overview of USGS information products, including maps, imagery, and publications, visit http://www.usgs.gov/pubprod/.

Any use of trade, firm, or product names is for descriptive purposes only and does not imply endorsement by the U.S. Government.

Although this information product, for the most part, is in the public domain, it also may contain copyrighted materials as noted in the text. Permission to reproduce copyrighted items must be secured from the copyright owner.

Suggested citation:

Martin, Peter, and Schroeder, R.A., 2015, The source, discharge, and chemical characteristics of selected springs, and the abundance and health of associated endemic anuran species in the Mojave network parks: U.S. Geological Survey Scientific Investigations Report 2015-5027, 128 p., http://dx.doi.org/10.3133/SIR20155027. 


\section{Acknowledgments}

This study was developed and funded in cooperation with the U.S. National Park Service. Special thanks to personnel of the U.S. National Park Service include the following: Debra Hughson (Science Advisor from the Mojave National Preserve); Linda Manning, Terry Fisk, and Eileen Hwang (Death Valley National Park); Anne Kearns and Tom Colhane (Mojave National Preserve); Sandee Dingman (Lake Mead National Recreation Area); and Paul DePrey, Michael Vamstead, and Kristen Lalumiere (Joshua Tree National Park).

Assistance was also provided by several employees of the U.S. Geological Survey. David E. Green from the U.S. Geological Survey National Wildlife Health Center, Madison, Wisconsin, provided the pathological analysis of specimens. Field assistance for collection of biological data was provided by Cindy Hitchcock, Sara Schuster, Greta Turschak, Adam Backlin, and Denise Clark. Robert Michel, Justin Kulongoski, Tony Brown, Mike Land, Larry Schneider, Allen Christensen and Andy Morita provided assistance with radiochemical interpretations, geochemical models, graphics, and mapping. 


\section{Contents}

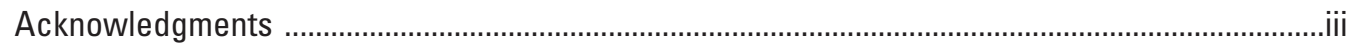

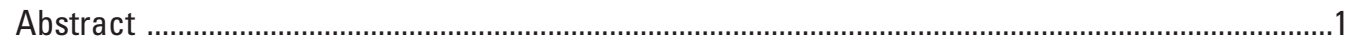

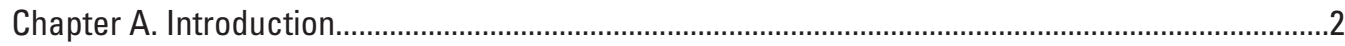

Physiographic and Hydrogeologic Setting of the Study Areas................................................

Darwin Falls, Death Valley National Park ........................................................................

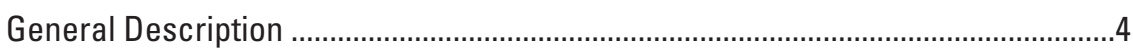

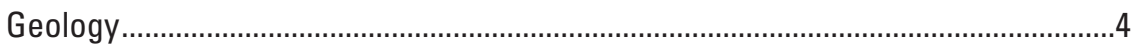

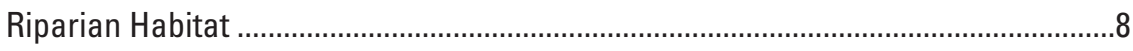

Location of Hydrological and Biological Surveys .................................................

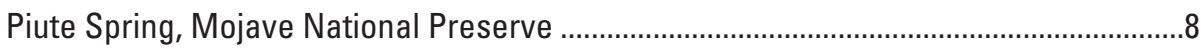

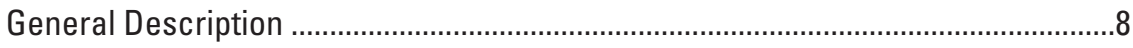

Geology

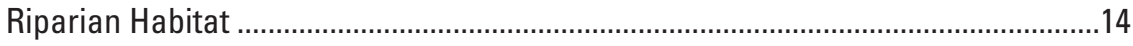

Location of Hydrological and Biological Surveys ................................................14

Fortynine Palms Oasis, Joshua Tree National Park ........................................................14

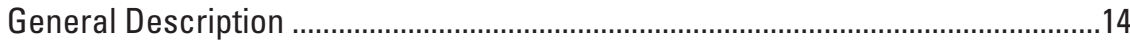

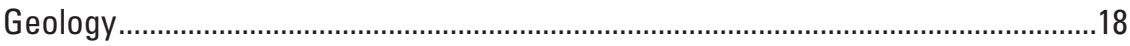

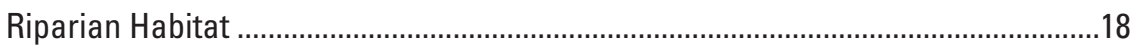

Location of Hydrological and Biological Surveys ...............................................18

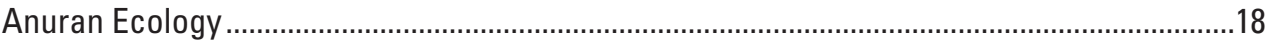

Western Toad (Anaxyrus boreas) ............................................................................18

Red-Spotted Toad (Anaxyrus punctatus) .....................................................................18

California Treefrog (Pseudacris cadaverina) ...................................................................23

Chapter B. Hydrological and Water-Quality Characterization of Selected Springs in the

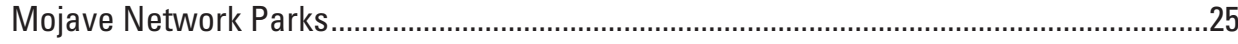

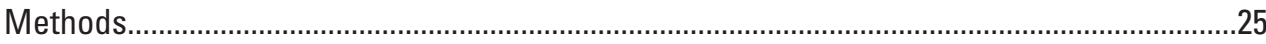

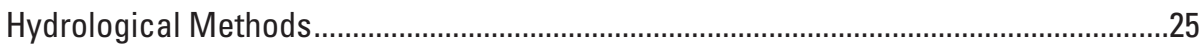

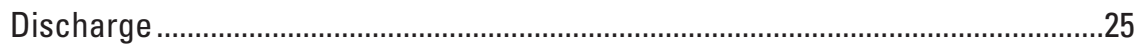

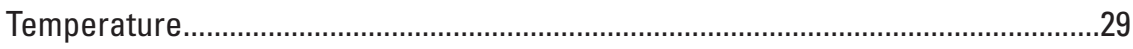

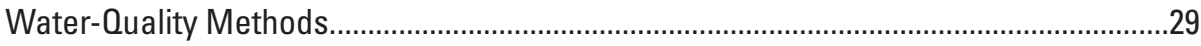

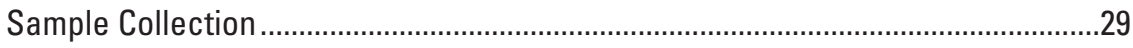

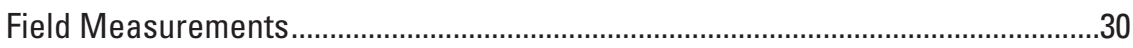

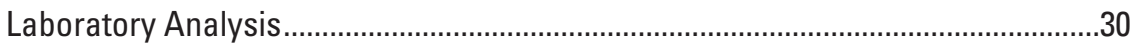

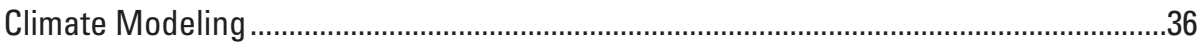

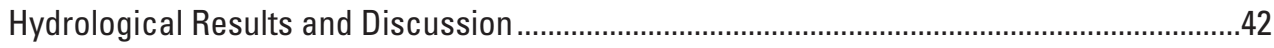

Darwin Falls, Death Valley National Park ...................................................................42

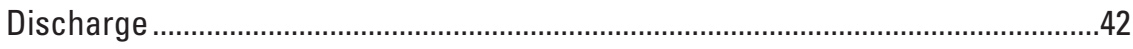

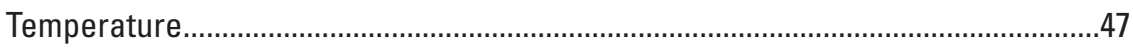

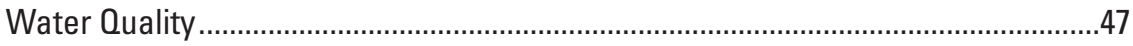

Altitude, Temperature, and Age of Recharge.....................................................4

Piute Spring, Mojave National Preserve ....................................................................49

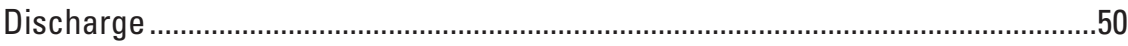




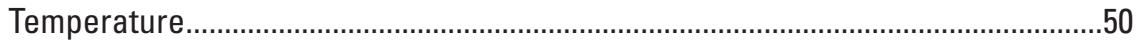

Water Quality.................................................................................................. 55

Altitude, Temperature, and Age of Recharge.......................................................5

Fortynine Palms Oasis, Joshua Tree National Park ………….........................................58

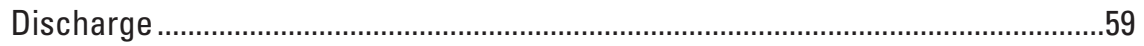

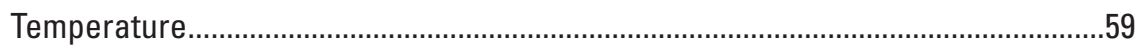

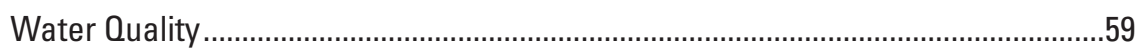

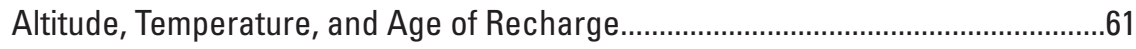

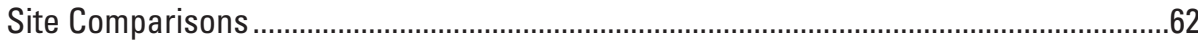

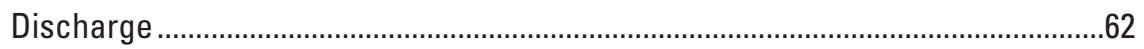

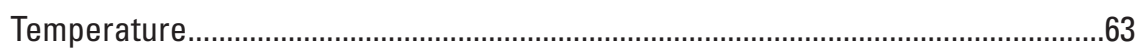

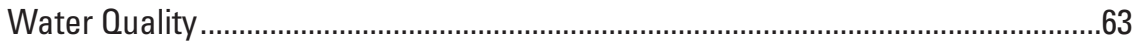

Field Measurements and Salinity.................................................................64

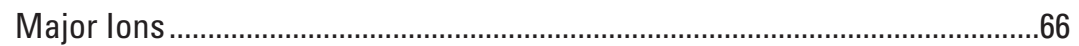

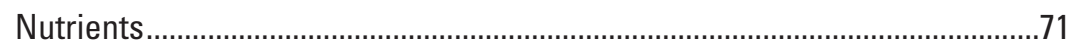

Trace Elements ..............................................................................................

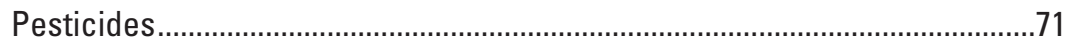

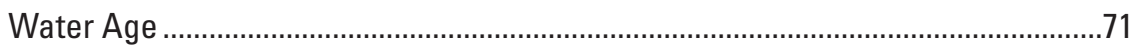

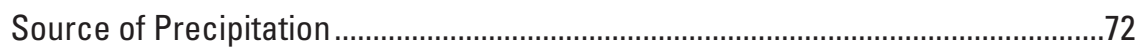

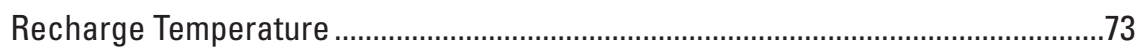

Climate73

Chapter C. Anuran Abundance and Health at Selected Springs in the Mojave

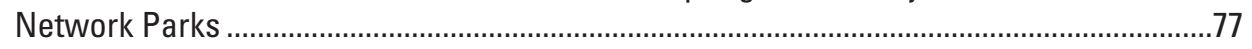

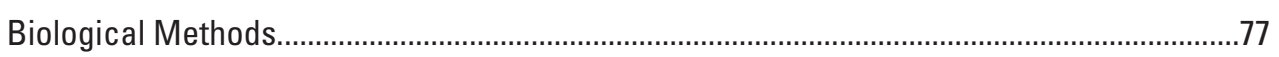

Aquatic Habitat and Endemic Anuran Surveys ………….............................................

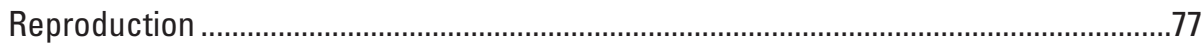

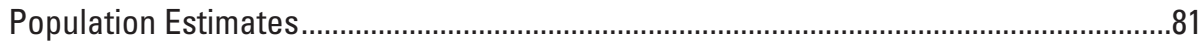

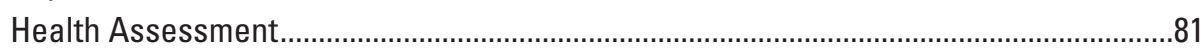

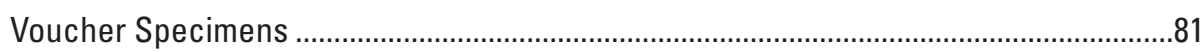

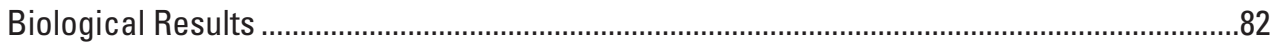

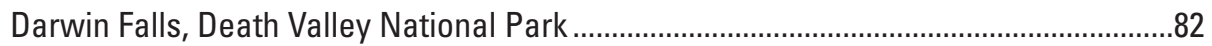

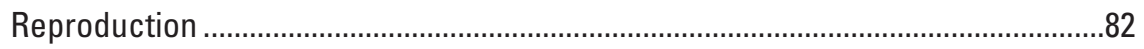

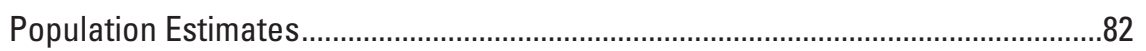

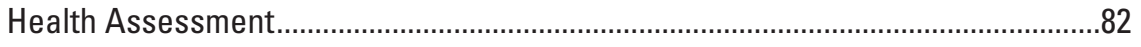

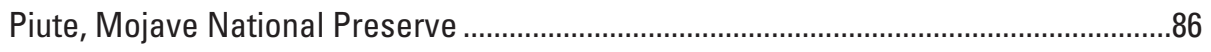

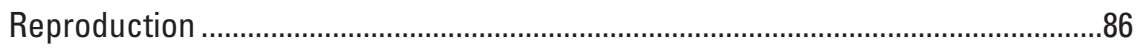

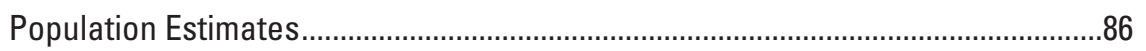

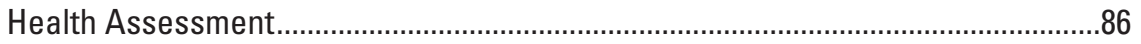

Fortynine Palms Oasis, Joshua Tree National Park …………........................................86

Reproduction ...................................................................................................

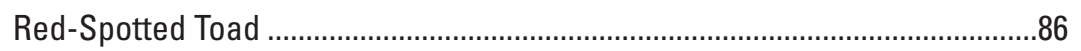

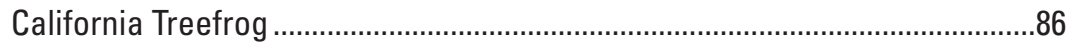

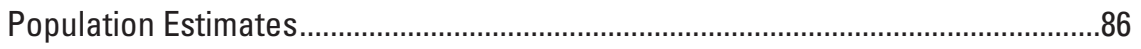

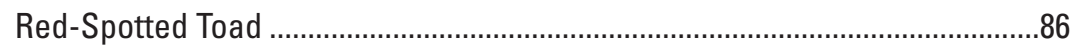

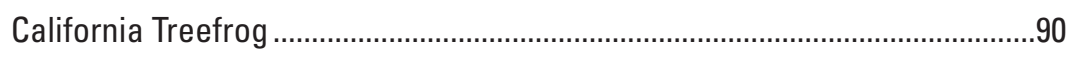

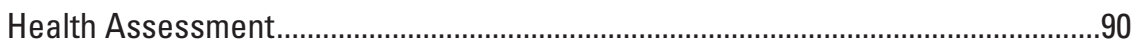


Red-Spotted Toad .........................................................................................90

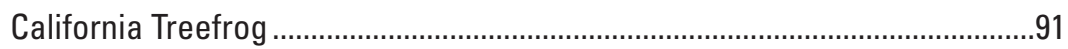

Rattlesnake Canyon, Joshua Tree National Park ............................................................91

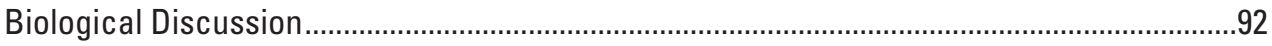

Darwin Falls, Death Valley National Park ....................................................................92

Piute Spring, Mojave National Preserve ………………..............................................94

Fortynine Palms Oasis, Joshua Tree National Park .........................................................95

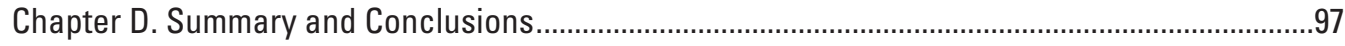

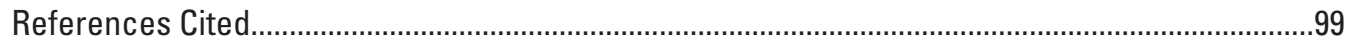

Appendix 1. Background Information on Classes, or Types, of Water-Quality Constituents Analyzed for the Springs Study in the Mojave Network

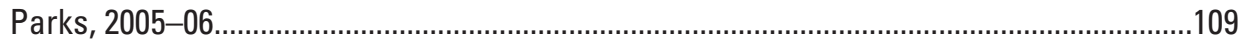

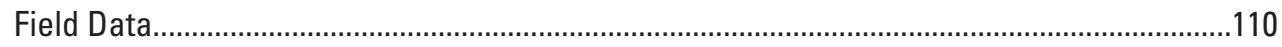

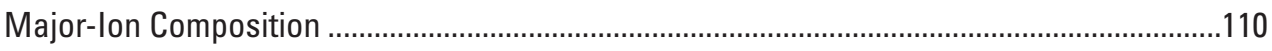

Chloride-to-Bromide Ratios .........................................................................................

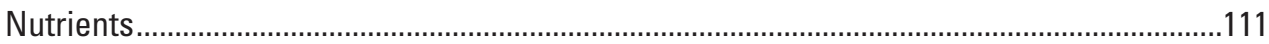

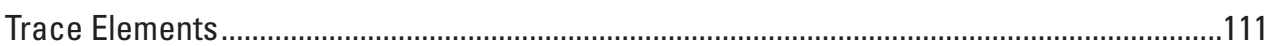

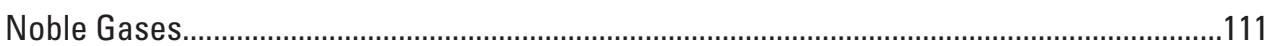

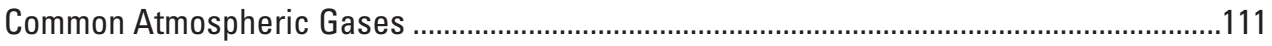

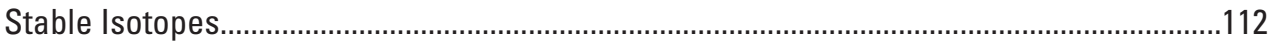

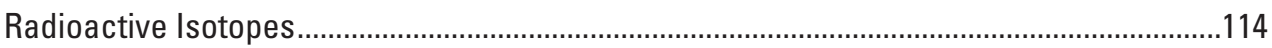

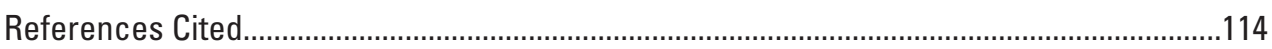

Appendix 2. Historical Water-Quality Data, 1987-2000 ……....................................................117

Appendix 3. Location of Biological-Survey Reaches, 2005-06 ...............................................121

Appendix 4. Location and Capture Information for Western Toads at Darwin Falls, Death Valley National Park, 1997-99...............................................................................123

Appendix 5. Location and Capture Information for Western Toads at Darwin Falls, Death Valley National Park, 2005.....................................................................................127 


\section{Figures}

1. Map showing Death Valley National Park, Mojave National Preserve, and Joshua Tree National Park, Mojave Network Parks, California, 2005-06..

2. Map showing Darwin Falls drainage basin, Mojave Network Parks, California, 2005-06.

3. Map showing geology of the Darwin Falls drainage basin and surrounding area, Mojave Network Parks, California, 2005-06...

4. Map showing geology of the Darwin Falls study area, Mojave Network Parks, California, 2005-06.

5. Photographs showing habitat and species of interest at Darwin Falls in the Mojave Network Parks, California, 2005-06...

6. Map showing survey reaches for hydrological and biological data collection at the Darwin Falls study area, Mojave Network Parks, California, 2005-06.

7. Map showing the Piute Spring drainage basin, Mojave Network Parks, California, 2005-06

8. Map showing geology of the Piute Spring drainage basin and surrounding area, Mojave Network Parks, California, 2005-06..

9. Map showing geology of the Piute Spring study area, Mojave Network Parks, California, 2005-06.

10. Photographs showing habitat and species of interest at Piute Spring in the Mojave Network Parks, California, 2005-06...

11. Map showing survey reaches for hydrological and biological data collection at the Piute Spring study area, Mojave Network Parks, California, 2005-06. .16

12. Map showing Fortynine Palms Oasis drainage basin, Mojave Network Parks, California, 2005-06.

13. Map showing geology of the Fortynine Palms Oasis drainage basin and surrounding area, Mojave Network Parks, California, 2005-06.

14. Map showing geology of the Fortynine Palms Oasis study area, Mojave Network Parks, California, 2005-06

15. Photographs showing the habitat and species of interest at Fortynine Palms Oasis in the Mojave Network Parks, California, 2005-06.

16. Map showing survey reaches for hydrological and biological data collection at the Fortynine Palms Oasis study area, Mojave Network Parks, California, 2005-06

17. Graphs showing modified Parameter Regression on Independent Slopes Model (PRISM) annual precipitation and deviation from the mean for the Darwin Falls drainage basin, Mojave Network Parks, California, 1895-2006.

18. Graphs showing comparison of the modified Parameter Regression on Independent Slopes Model (PRISM) annual precipitation and instantaneous discharge measurements in the Mojave Network Parks, California, 2005-06.

19. Graphs showing comparison of daily mean discharge at the U.S. Geological Survey gaging station on Darwin Wash and modified Parameter Regression on Independent Slopes Model (PRISM) annual precipitation, Mojave Network Parks, California, 1963-89.

20. Graph showing air and water temperatures at the Darwin Falls study area, Mojave Network Parks, California, 2005-06.. 
21. Graphs showing modified Parameter Regression on Independent Slopes Model (PRISM) annual precipitation and deviation from the mean for Piute Spring drainage basin, Mojave Network Parks, 1895-2006.

22. Graph showing discharge for Piute Creek collected by the Viceroy Gold Corporation, 1987-2000, and modified Parameter Regression on Independent Slopes Model (PRISM) annual precipitation, 1980-2000, Mojave Network Parks, California

23. Graph showing air and water temperatures at the Piute Spring study area, Mojave Network Parks, California, 2005-06.

24. Graph showing specific conductance and arsenic concentrations for samples collected in the Piute Creek study area by Viceroy Gold Corporation, 1987-2000, and by the U.S. Geological Survey for this study, 2005-06, Mojave Network Parks, California

25. Graphs showing modified Parameter Regression on Independent Slopes Model (PRISM) annual precipitation and deviation from the mean for Fortynine Palms Oasis drainage basin, Mojave Network Parks, 1895-2006

26. Graph showing air and water temperatures at Fortynine Palms Oasis study area, Mojave Network Parks, California, 2005-06

27. Graph showing specific conductance in samples collected at the Darwin Falls, Piute Spring, and Fortynine Palms Oasis study areas, Mojave Network Parks, California, 2005-06.

28. Graph showing relation between specific conductance and residue on evaporation (ROE) in samples collected at the Darwin Falls, Piute Spring, and Fortynine Palms Oasis study areas, Mojave Network Parks, California, 2005-06.

29. Piper diagram showing major-ion composition in samples collected at the Darwin Falls, Piute Spring, and Fortynine Palms Oasis study areas, Mojave Network Parks, California, 2005-06

30. Graph showing chloride relative to bromide concentrations in samples collected at the Darwin Falls, Piute Spring, and Fortynine Palms Oasis study areas, Mojave Network Parks, California, 2005-06

31. Graph showing chloride relative to sulfate concentrations in samples collected at the Darwin Falls, Piute Spring, and Fortynine Palms Oasis study areas, Mojave Network Parks, California, 2005-06.

32. Graph showing chloride relative to boron concentrations in samples collected at the Darwin Falls, Piute Spring, and Fortynine Palms Oasis study areas, Mojave Network Parks, California, 2005-06.

33. Graph showing relation between delta deuterium and delta oxygen-18 in samples collected at the Darwin Falls, Piute Spring, and Fortynine Palms Oasis study areas, Mojave Network Parks, California, 2005-06..

34. Graphs showing basin characterization model (BCM) simulated maximum and minimum annual temperature and deviation from the mean minimum annual temperature in the California part of the Mojave Desert, 1895-2006.

35. Graphs showing modified Parameter Regression on Independent Slopes Model (PRISM) annual precipitation and deviation from the mean in the California part of the Mojave Desert, 1895-2006...

36. Drawings showing Gosner stages of tadpole development ...........................................80

37. Graph showing Western toad (Anaxyrus boreas) body mass as compared with snout-vent length at Darwin Falls study area, Death Valley National Park, California, 2005-06. 
38. Graph showing red-spotted toad (Anaxyrus punctatus) body mass as compared with snout-vent length at Piute Spring study area, Mojave Network Parks, California, 2005-06

39. Photographs showing abnormalities observed in red-spotted toads (Anaxyrus punctatus) at Piute Spring study area, Mojave Network Parks,

California, 2005-06

40. Graph showing red-spotted toad body mass as compared with snout-vent length at Fortynine Palms Oasis study area, Mojave Network Parks, California, 2005-06

41. Graph showing comparison of the body mass as compared with snout-vent length between red-spotted toads from Fortynine Palms Oasis and Piute Spring study areas, Mojave Network Parks, California, 2005-06.

42. Graph showing California treefrog body mass as compared with snout-vent length at Fortynine Palms Oasis study area, Mojave Network Parks, California, 2005-06

43. Photograph showing California treefrog (Pseudacris cadaverina) with chigger mites (Trombiculidae) at Fortynine Palms Oasis study area, Mojave Network Parks, California, 2005-06. 


\section{Tables}

1. Identification information for sites sampled for the Mojave Network Parks, California, 2005-06.

2. Instantaneous discharge and general water-quality indicators determined in the field on samples collected in the Mojave Network Parks, California, 2005-06.........27

3. Concentrations of dissolved major and selected minor ions in samples collected from the Darwin Falls, Piute Spring, and Fortynine Palms Oasis study areas, Mojave Network Parks, California, 2005-06

4. Concentrations of dissolved nutrients in samples collected from the Darwin Falls, Piute Spring, and Fortynine Palms Oasis study areas, Mojave Network Parks, California, 2005-06

5. Concentrations of dissolved selected trace elements in samples collected from the Darwin Falls, Piute Spring, and Fortynine Palms Oasis study areas, Mojave Network Parks, California, 2005-06

6. Results of analyses for radioactive and stable isotopes in samples collected from the Darwin Falls, Piute Spring, and Fortynine Palms Oasis study areas, Mojave Network Parks, California, 2005-06.

7. Concentrations of dissolved common atmospheric gases and nitrogen- and argon-based excess air concentrations and recharge temperatures of samples collected from the Darwin Falls, Piute Spring, and Fortynine Palms Oasis study areas, Mojave Network Parks, California, 2005-06

8. Concentrations of dissolved noble (inert) gases, tritium-helium-3 age, and noble-gas based recharge temperature of samples collected from the Darwin Falls, Piute Spring, and Fortynine Palms Oasis study areas, Mojave Network Parks, California, 2005-06.

9. Concentrations of dissolved pesticides in samples collected from the Darwin Falls, Piute Spring, and Fortynine Palms Oasis study areas, Mojave Network Parks, California, 2005-06.

10. Annual and seasonal streamflow and base flow at the Darwin Wash gaging station (10250800) calculated using the PART program, Mojave Network Parks, California, 1963-88

11. Selected historical and recent instantaneous discharge collected at Darwin Wash in the Darwin Falls study area, Mojave Network Parks, California, 2005-06

12. Summary of average altitude of recharge estimated using water isotopes for Darwin Spring, Piute Spring, Piute Seep, and the Upper Pool at the Fortynine Palms Oasis, Mojave Network Parks, California, 2005-06.

13. Historical instantaneous discharge collected at the Piute Spring study area, Mojave Network Parks, California, 1909-2003.

14. Statistical summary of water-quality data for 51 samples collected from Piute Creek by Viceroy Gold Corporation between December 1987 and December 2000, and data from one sample collected by the U.S. Geological Survey September 2, 1981, Mojave Network Parks, California

15. Annual, and spring and summer differences in specific conductance and dissolved-solids concentrations (reported as residue on evaporation) collected at the Darwin Falls, Piute Spring, and Fortynine Palms Oasis study areas, Mojave Network Parks, California, 2005-06 
16. Saturation indices calculated by using the computerized geochemical model, PHREEOC, for selected calcium and silica minerals in water samples collected at the Darwin Falls, Piute Spring, and Fortynine Palms Oasis study areas, Mojave Network Parks, California, 2005-06...

17. Recharge temperatures calculated using the average atmospheric lapse rate and gas-concentration data on selected water samples collected at the Darwin Falls, Piute Spring, and Fortynine Palms Oasis study areas, Mojave Network Parks, California, 2005-06.

18. Summary of site locations, species of interest, and survey dates for the Darwin Falls, Piute Spring, and Fortynine Palms Oasis study areas, Mojave Network Parks, California, 2005-06.

19. Location of biological surveys at Darwin Falls, Piute Spring, and Fortynine Palms Oasis study areas, Mojave Network Parks, California, 2005-06.

20. Catalog information for voucher specimens collected at Darwin Falls, Piute Spring, and Fortynine Palms Oasis study areas, Mojave Network Parks, California, 2005-06.

21. Population estimates for the species of interest at Darwin Falls, Piute Spring, and Fortynine Palms Oasis study areas, Mojave Network Parks, California, 2005-06.

22. Pathology results from the U.S. Geological Survey National Wildlife Health Center for targeted endemic anuran samples from Darwin Falls, Piute Spring, and Fortynine Palms Oasis study areas, Mojave Network Parks, California, 2005-06.

23. Classification and definition of abnormalities present in red-spotted toads (Anaxyrus punctatus) at Piute Spring study area, Mojave Network Parks, California, 2005-06

24. Percentage of abnormality types in red-spotted toads (Anaxyrus punctatus) observed at Piute Spring study area, Mojave Network Parks, California, 2005-06

2-1. Historical water-quality data for 51 samples collected by the Viceroy Gold Corporation from Piute Creek between December 1987 and December 2000

3-1. Location of biological-survey reaches for the Darwin Falls, Piute Spring, and Fortynine Palms Oasis study areas, Mojave Network Parks, California, 2005-06.........122

4-1. Location and capture information for western toads at Darwin Falls, Death Valley National Park, 1997-99.....

5-1. Location and capture information for western toads at Darwin Falls, Death Valley National Park, 2005. 


\section{Conversion Factors}

Inch/Pound to International System of Units

\begin{tabular}{lcl}
\hline \multicolumn{1}{c}{ Multiply } & By & \multicolumn{1}{c}{ To obtain } \\
\hline inch (in.) & Length & \\
mile (mi) & 2.54 & centimeter $(\mathrm{cm})$ \\
& 1.609 & kilometer $(\mathrm{km})$ \\
\hline cubic foot per second $\left(\mathrm{ft}^{3} / \mathrm{s}\right)$ & Flow rate & \\
gallon per minute $(\mathrm{gal} / \mathrm{min})$ & 0.02832 & cubic meter per second $\left(\mathrm{m}^{3} / \mathrm{s}\right)$ \\
& 0.06309 & liter per second $(\mathrm{L} / \mathrm{s})$ \\
\hline picocurie per liter $(\mathrm{pCi} / \mathrm{L})$ & Radioactivity & \\
\hline
\end{tabular}

International System of Units to Inch/Pound

\begin{tabular}{|c|c|c|}
\hline Multiply & By & To obtain \\
\hline \multicolumn{3}{|c|}{ Length } \\
\hline centimeter $(\mathrm{cm})$ & 0.3937 & inch (in.) \\
\hline millimeter (mm) & 0.03937 & inch (in.) \\
\hline meter $(\mathrm{m})$ & 3.281 & foot $(\mathrm{ft})$ \\
\hline kilometer $(\mathrm{km})$ & 0.6214 & mile (mi) \\
\hline kilometer (km) & 0.5400 & mile, nautical (nmi) \\
\hline micrometer $(\mu \mathrm{m})$ & 0.000001 & meter $(\mathrm{m})$ \\
\hline \multicolumn{3}{|c|}{ Area } \\
\hline square meter $\left(\mathrm{m}^{2}\right)$ & 10.764 & square feet $\left(\mathrm{ft}^{2}\right)$ \\
\hline square kilometer $\left(\mathrm{km}^{2}\right)$ & 247.1 & acre \\
\hline square kilometer $\left(\mathrm{km}^{2}\right)$ & 0.3861 & square mile $\left(\mathrm{mi}^{2}\right)$ \\
\hline \multicolumn{3}{|c|}{ Volume } \\
\hline milliliter $(\mathrm{mL})$ & 0.03381 & ounce (oz) \\
\hline liter (L) & 0.264 & gallon (gal) \\
\hline cubic meter $\left(\mathrm{m}^{3}\right)$ & 264.172 & gallon (gal) \\
\hline \multicolumn{3}{|c|}{ Flow rate } \\
\hline cubic meter per year $\left(\mathrm{m}^{3} / \mathrm{yr}\right)$ & 0.000811 & acre-foot per year (acre-ft/yr) \\
\hline \multicolumn{3}{|c|}{ Mass } \\
\hline $\operatorname{gram}(\mathrm{g})$ & 0.03527 & ounce, avoirdupois (oz) \\
\hline
\end{tabular}

\section{Supplemental Information}

Temperature in degrees Celsius $\left({ }^{\circ} \mathrm{C}\right)$ may be converted to degrees Fahrenheit $\left({ }^{\circ} \mathrm{F}\right)$ as follows:

$$
{ }^{\circ} \mathrm{F}=\left(1.8 x^{\circ} \mathrm{C}\right)+32
$$

Altitude, as used in this report, refers to distance above the vertical datum.

Specific conductance is given in microsiemens per centimeter at 25 degrees Celsius $\left(\mu \mathrm{S} / \mathrm{cm}\right.$ at $\left.25^{\circ} \mathrm{C}\right)$.

Concentrations of chemical constituents in water are given either in milligrams per liter (mg/L) or micrograms per liter $(\mu \mathrm{g} / \mathrm{L})$. 


\section{Datum}

Vertical coordinate information is referenced to the North American Vertical Datum of 1988 (NAVD 88).

Horizontal coordinate information is referenced to the North American Datum of 1983 (NAD 83).

\section{Abbreviations}

$\delta^{\mathrm{i}} \mathrm{E}$

$1-\sigma$

${ }^{3} \mathrm{He}$

$\mathrm{Ar}$

ARMI

As

ASHAP

B

$\mathrm{Ba}$

BCM

$\mathrm{Bd}$

$\mathrm{Br}$

C

${ }^{12} \mathrm{C}$

${ }^{13} \mathrm{C}$

${ }^{14} \mathrm{C}$

$\mathrm{Ca}$

$\mathrm{cm}^{3}$ STP $/ \mathrm{g} \mathrm{H}_{2} \mathrm{O}$

$\mathrm{CH}_{4}$

$\mathrm{CI}$

$\mathrm{Cl}$

$\mathrm{CO}_{2}$

CRES

D

DIC

DNA

DO delta notation, the ratio of the heavier isotope (i) to the more common lighter isotope of an element (E), relative to a standard reference material, expressed as per mil (parts per thousand)

one-sigma

helium-3

argon

Amphibian Research and Monitoring Initiative

arsenic

Aquatic Species and Habitat Assessment Protocol

boron

barium

Basin Characterization Model

Bactrochochytrium dendrobatidis

bromide

carbon

carbon-12

carbon-13

carbon-14

calcium

cubic centimeters per gram of water at standard temperature and pressure methane

confidence interval

chloride

carbon dioxide

Conservation and Research for Endangered Species

deuterium

dissolved inorganic carbon

deoxyribonucleic acid

dissolved oxygen 


\begin{tabular}{|c|c|}
\hline DSC & dissolved-solids concentration \\
\hline $\mathrm{EC}$ & specific conductance \\
\hline EPA & U.S. Environmental Protection Agency \\
\hline $\mathrm{F}$ & fluoride \\
\hline $\mathrm{Fe}$ & iron \\
\hline GPS & Global Positioning System \\
\hline $\mathrm{H}$ & hydrogen \\
\hline 'H & hydrogen-1 or protium \\
\hline${ }^{2} \mathrm{H}$ or $\mathrm{D}$ & hydrogen-2 or deuterium \\
\hline${ }^{3} \mathrm{H}$ & hydrogen-3 or tritium \\
\hline $\mathrm{H}_{2} \mathrm{~S}$ & hydrogen sulfide \\
\hline $\mathrm{He}$ & helium \\
\hline${ }^{3} \mathrm{He}$ & helium-3 \\
\hline${ }^{4} \mathrm{He}$ & helium-4 \\
\hline ID & identification number \\
\hline In situ & on site \\
\hline Jmz & Jurassic granite \\
\hline K & potassium \\
\hline Kjeldahl-N & ammonia plus organic nitrogen \\
\hline $\mathrm{KJg}$ & Cretaceous-Jurassic granite \\
\hline $\mathrm{Kr}$ & krypton \\
\hline $\mathrm{Li}$ & lithium \\
\hline LLID & latitude and longitude identifier \\
\hline LLNL & Lawrence Livermore National Laboratory \\
\hline LRL & laboratory reporting level \\
\hline MCL & maximum contaminant level \\
\hline $\mathrm{Mg}$ & magnesium \\
\hline $\mathrm{Mn}$ & manganese \\
\hline MOJN & Mojave Desert Network \\
\hline MWL & meteoric water line \\
\hline $\mathrm{N}$ & nitrogen \\
\hline $\mathrm{N}_{2}$ & nitrogen gas \\
\hline $\mathrm{Na}$ & sodium \\
\hline $\mathrm{Ne}$ & neon \\
\hline $\mathrm{NH}_{4}$ & ammonia \\
\hline $\mathrm{NH}_{4}-\mathrm{N}$ & ammonia reported as nitrogen \\
\hline $\mathrm{NO}_{2}$ & nitrite \\
\hline $\mathrm{NO}_{2}-\mathrm{N}$ & nitrite reported as nitrogen \\
\hline $\mathrm{NO}_{3}$ & nitrate \\
\hline
\end{tabular}




\begin{tabular}{|c|c|}
\hline $\mathrm{NO}_{3}-\mathrm{N}$ & nitrate reported as nitrogen \\
\hline NPS & National Park Service \\
\hline NRP & National Research Program \\
\hline NWHC & National Wildlife Health Center \\
\hline NWIS & National Water Information System \\
\hline NWQL & National Water Quality Laboratory \\
\hline 0 & oxygen \\
\hline $\mathrm{O}_{2}$ & oxygen gas \\
\hline${ }^{16} 0$ & oxygen-16 \\
\hline${ }^{18} \mathrm{O}$ & oxygen-18 \\
\hline$P$ & phosphorus \\
\hline PART & streamflow partitioning program \\
\hline PCR & polymerase chain reaction \\
\hline Pzs & Permian sedimentary rocks \\
\hline PHREEQC & a computerized geochemical model pH-Redox-EQuilibrium \\
\hline PIT & passive integrated transponder \\
\hline pmc & percent modern carbon \\
\hline $\mathrm{PO}_{4}-\mathrm{P}$ & orthophosphate reported as phosphorus \\
\hline PRISM & Parameter Regression on Independent Slopes Model \\
\hline Qa & Quaternary alluvium \\
\hline QTV & Quaternary-Tertiary volcanics \\
\hline${ }^{87} \mathrm{Rb}$ & rubidium-87 \\
\hline Redox & oxidation-reduction state of water \\
\hline ROE & residue on evaporation at $180^{\circ} \mathrm{C}$ \\
\hline Se & selenium \\
\hline SI & saturation index \\
\hline $\mathrm{SiO}_{2}$ & silica \\
\hline SLAP & Standard Light Antarctic Precipitation \\
\hline $\mathrm{SO}_{4}$ & sulfate \\
\hline $\mathrm{Sr}$ & strontium \\
\hline${ }^{86} \mathrm{Sr}$ & strontium-86 \\
\hline${ }^{87} \mathrm{Sr}$ & strontium-87 \\
\hline SVL & snout-vent length \\
\hline TU & tritium units \\
\hline Tvs & Tertiary volcanic and sedimentary rocks \\
\hline $\mathrm{U}$ & uranium \\
\hline USGS & U.S. Geological Survey \\
\hline UVB & ultraviolet B shortwave rays \\
\hline V & vanadium \\
\hline
\end{tabular}


VPDB

VSMOW

$\mathrm{Xe}$

$\mathrm{Xm}$
Vienna Pee Dee Belemnite

Vienna Standard Mean Ocean Water

xenon

Proterozoic metamorphic rocks 
xviii 


\title{
The Source, Discharge, and Chemical Characteristics of Selected Springs, and the Abundance and Health of Associated Endemic Anuran Species in the Mojave Network Parks
}

\author{
Compiled by Peter Martin and Roy A. Schroeder
}

With chapters by Roy A. Schroeder, Gregory A. Smith, Peter Martin, Alan L. Flint, Elizabeth Gallegos, and Robert N. Fisher

\section{Abstract}

Hydrological and biological investigations were done during 2005 and 2006 in cooperation with the U.S. National Park Service to investigate the source, discharge, and chemical characteristics of selected springs and the abundance and health of endemic anuran (frog and toad) species at Darwin Falls in Death Valley National Park, Piute Spring in Mojave National Preserve, and Fortynine Palms Oasis in Joshua Tree National Park. Discharge from the springs at these sites sustains isolated riparian habitats in the normally dry Mojave Desert. Data were collected on water quantity (discharge) and quality, air and water temperature, and abundance and health of endemic anuran species. In addition, a single survey of the abundance and health of endemic anuran species was completed at Rattlesnake Canyon in Joshua Tree National Park. Results from this study were compared to limited historical data, where they exist, and can provide a baseline for future hydrological and biological investigations to evaluate the health and sustainability of the resource and its response to changing climate and increasing human use.

Radiocarbon dating of the water yielded estimated ages of about 7,000 years at Piute Spring and about 3,000 years at Darwin Spring, and tritium-helium-3 dating indicated an age of less than 2 years at Fortynine Palms Oasis. Stable hydrogen-isotope ratios were used to interpret an average altitude of recharge of 2,348 meters for Darwin Spring (about 1,415 meters higher than the altitude of Darwin Spring), 1,668 meters for Piute Spring (about 766 meters higher than the altitude of Piute Spring), and 1,400 meters for the Upper Pool at Fortynine Palms Oasis (about 543 meters higher than the altitude of the Upper Pool). Water-quality data collected for this study did not appear to be sensitive to trends in precipitation or seasonality in the Darwin Falls and Piute
Spring study areas; however, it was sensitive to trends in Fortynine Palms Oasis where salinity increased by more than 10 percent during the 2 years of this study. Such a rapid response is consistent with the comparatively short travel time of less than 2 years from recharge to discharge at Fortynine Palms Oasis. Of the 14 trace elements analyzed, only concentrations of uranium at Fortynine Palms Oasis and arsenic at Darwin Spring were above drinking water standards; both constituents are derived from natural sources in the drainage basin and, therefore, are likely to have accumulated as a result of natural processes.

Endemic anuran species were surveyed at Darwin Falls for the western toad (Anaxyrus boreas) and the red-spotted toad (Anaxyrus punctatus), at Piute Spring for the red-spotted toad, and at Fortynine Palms Oasis for the red-spotted toad and California treefrog (Pseudacris cadaverina). Historically, redspotted toads were at the edge of their range at Darwin Falls, but they were not detected during this study and have not been detected since the early 1980s. The 2006 western toad population at Darwin Falls was estimated at 381 adults (95-percent confidence interval [CI] of 314-482). The population of red-spotted toads at Piute Spring was estimated at 1,153 adults (95-percent CI of 935-1,503). However, an elevated rate of abnormalities (approximately 5 percent) was recorded in redspotted toads as well as the presence of the chytrid fungus, Bactrochochytrium dendrobatidis, at Piute Spring. In Joshua Tree National Park, the California treefrog now occupies only three of the seven historically occupied drainages. Populations of California treefrogs at Fortynine Palms Oasis have declined more than 50 percent from 288 in $1969-71$ to 109 in 2006 . A similar decline was observed in the populations of red-spotted toads at Fortynine Palms Oasis from 300 adults in 1969-71 to 155 adults (95-percent CI of 90-139) in 2006. The red-spotted toads at Fortynine Palms Oasis also exhibited the presence of Bactrochochytrium dendrobatidis. 


\section{Chapter A. Introduction}

\author{
By Roy A. Schroeder, Elizabeth Gallegos, Gregory A. \\ Smith, Peter Martin, and Robert N. Fisher
}

The Mojave Desert consists of 152,000 square kilometers $\left(\mathrm{km}^{2}\right)$ of land that extends across eastern California, southern Nevada, northern Arizona, and western Utah (fig. 1), and is considered one of the most climatically extreme environments within the United States (Bailey, 1995). A substantial amount of the Mojave Desert's biodiversity is present in isolated riparian habitats that are supported by perennial springs, and these habitats commonly include a few endemic anuran (frogs and toads) species (Greene and Luke, 1996). Anurans, whose skin is susceptible to desiccation, are at the edge of their physiological limits in this arid region and, therefore, rely on spring-supported habitats for breeding and recruitment (Greene and Luke, 1996). Desert springs generally discharge small volumes of water that are derived from either infrequent, short-lived, high-intensity precipitation events; regional interbasin groundwater flow; or a combination of both. Reliance on these processes makes these riparian habitats sensitive to climatic changes (such as in precipitation and air temperature) and anthropogenic effects (such as water consumption, pollution, introduction of invasive species, and recreational use). It is necessary to understand the hydrological processes supporting spring discharge in order to appropriately manage these riparian habitats. First-order insight into these processes can be gained by examining spring discharge, sources of water to the springs, and rates of recharge to the springs. Detailed habitat and anuran community characterizations over time are needed to document changes in habitat and anuran community dynamics that are taking place in response to human and natural disturbances, declining water supply, and natural cyclical patterns. The U.S. Geological Survey (USGS), in cooperation with the U.S. National Park Service (NPS), undertook this study to help determine the hydrological and biologic health of these riparian habitats, and their susceptibility to drought and possible adverse human effects such as groundwater development. The biological data collected for this study are part of the USGS Amphibian Research and Monitoring Initiative (ARMI), which is a national program of amphibian monitoring, research, and conservation.

The state of knowledge regarding the health of riparian biota and the hydrology of perennial desert springs within the Mojave Network Parks (including the Death Valley National Park, Mojave National Preserve, and Joshua Tree National Park) was inadequate to properly manage these resources when this study was started in 2005 (fig. 1). Biological surveys have identified the presence of six anuran species, but little data are available on the hydrological properties of their associated springs habitat (Stebbins, 2003). Poff and others (1997), and Baron and others (2002) documented the adverse effect of urbanization-altered flow regimes on amphibians, and Corn (2005) reported that temperature and precipitation fluctuations have also affected anurans; the extent to which changes in amphibian populations are in response to natural fluctuations or to human effects remains unclear. Pohlmann and others (1998) used water-quality, and stable- and radiogenicisotope data to infer water source for 36 springs in and near the Lake Mead National Recreation Area (fig. 1), which also lies within the Mojave Network Parks. The Metropolitan Water District of Southern California proposed a water storage project known as the Cadiz Groundwater Storage and Dry-Year Supply Program adjacent to the Mojave National Preserve (fig. 1) in the late 1990s, which planned to recharge and store Colorado River (fig. 1) water in the Fenner, Bristol, and Cadiz drainage basins during wet years, and to withdraw stored Colorado River water and local groundwater during dry years (Metropolitan Water District of Southern California and Bureau of Land Management, 2001). There were concerns that the project might negatively affect the flow of springs in the Mojave National Preserve (fig. 1; Metropolitan Water District and Bureau of Land Management, 2001). Because of these concerns, a groundwater monitoring and management plan was developed in the final environmental impact statement/ environmental impact report for the Cadiz Groundwater Storage and Dry-Year Supply Program to ensure that the project did not cause adverse effects to groundwater-related critical resources (Metropolitan Water District and Bureau of Land Management, 2001). In 2002, the Metropolitan Water District of Southern California decided not to proceed with the Cadiz Groundwater Storage and Dry-Year Supply Program, and as of 2014 the Program has not been constructed.

In 1999, the NPS instituted a program to inventory and monitor natural resources in approximately 270 park units across the Nation, referred to as the Inventory and Monitoring Program (National Park Service, 1999). The program is being implemented by forming 32 networks of parks that share common management concerns and geography. The purpose of the monitoring program is to provide park managers with status and trends data on select indicators that represent the health of natural resources in the different park units. These indicators are termed "vital signs," and they will be monitored under a set of protocols that provide detailed guidance on the methods, schedules, analytical tools, and reporting procedures.

In 2004, the Mojave Network Parks Inventory and Monitoring program began a process to identify and rank vital signs for each of the park units within the Mojave Network Parks. Monitoring the vital signs of aquatic and riparian habitats was ranked high by the Mojave Network Parks for the Death Valley National Park, the Mojave National Preserve, and the Joshua Tree National Park (Chung-MacCoubrey and others, 2008). Groundwater is fundamental to the function of desert hydrological systems, and alteration to the groundwater flow and quality directly affects aquatic and riparian ecosystems. 


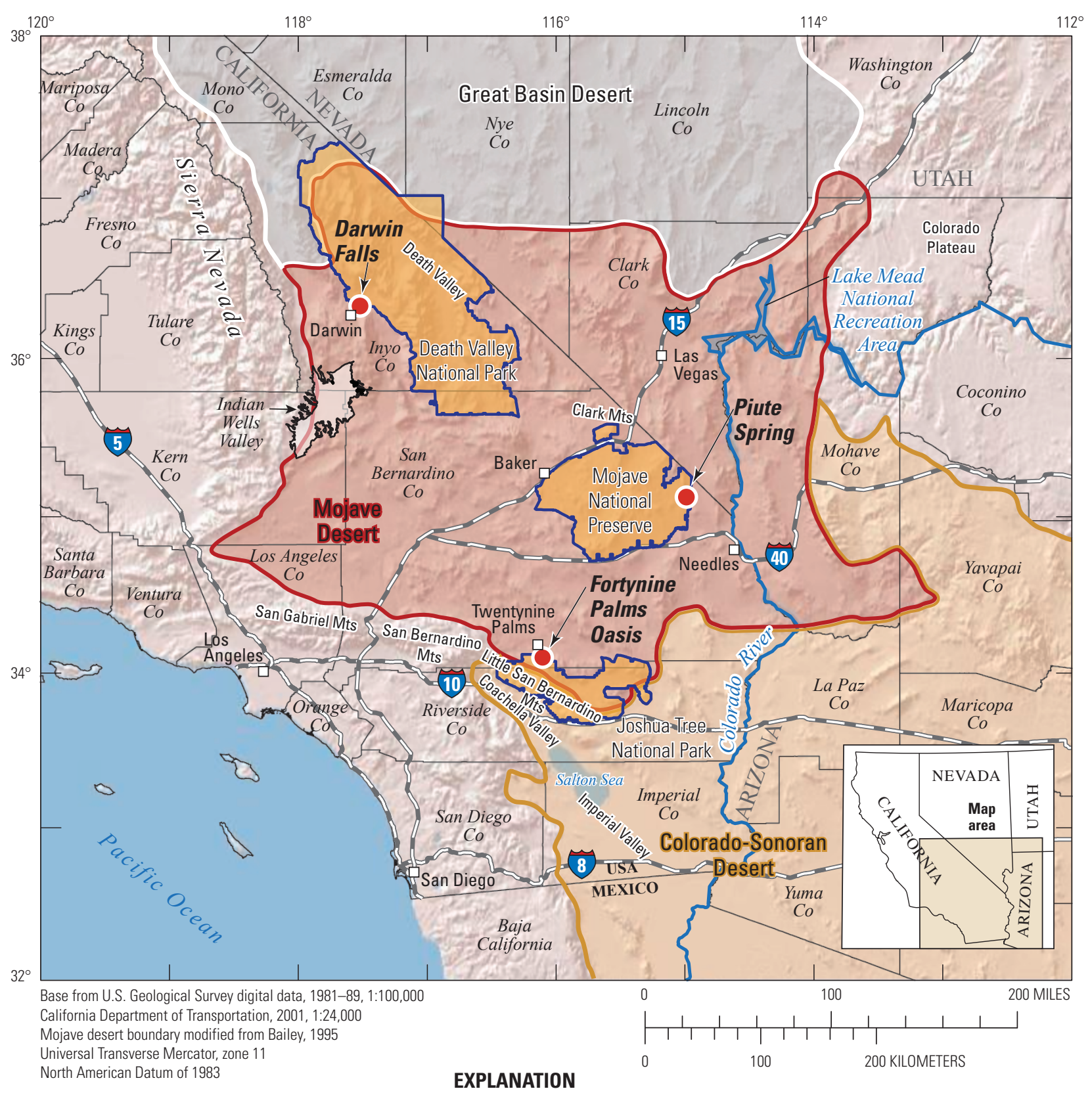

Study area

Figure 1. Death Valley National Park, Mojave National Preserve, and Joshua Tree National Park, Mojave Network Parks, California, 2005-06.

In 2005, the U.S. Geological Survey (USGS) in cooperation with the NPS began a study to investigate the source, discharge, and chemical characteristics of selected springs, and the abundance and health of endemic anuran (frog and toad) species in the Death Valley National Park, Mojave National Preserve, and Joshua Tree National Park. After compiling and assessing existing survey data, Mojave Network Parks' scientists identified a riparian habitat sustained by discharge from springs in these parks, and identified the following areas with the greatest data gaps that would benefit from a focused field-oriented study: Darwin Falls in the Death Valley National Park; Piute Spring in the Mojave National Preserve; and Fortynine Palms Oasis in the Joshua Tree National Park (fig. 1). The objective of these focused field-oriented studies was to collect hydrological and biological data for a 2-year period (2005-06) to help determine the hydrological and biologic health of these riparian habitats, and their susceptibility to drought and possible adverse human effects such as groundwater development. 
Source, Discharge, and Chemical Characteristics of Selected Springs and Endemic Anuran Species, Mojave Network Parks

The purpose of this report is to summarize the hydrological and biological data collected during 2005-06 at Darwin Falls in the Death Valley National Park, Piute Spring in the Mojave National Preserve, and Fortynine Palms Oasis in the Joshua Tree National Park and to present interpretations derived from these data concerning the hydrological and biologic health of these riparian habitats, and their susceptibility to drought and possible adverse human effects. Results from this study were compared to historical data, and can provide a baseline for future hydrological and biological investigations to evaluate health and sustainability of the resource as well as its response to changing climate and increases in human use.

The chemical characteristics and age of the spring waters that sustain the riparian habitats were used to help explain its source and variability in its discharge and water quality. Discharge and temperature data were used to help define each spring's hydrological system and its response to climatic fluctuations. Baseline biological information presented for each riparian habitat studied included (1) aquatic habitat and general biotic species, (2) endemic anuran reproduction, (3) endemic anuran population estimates, and (4) endemic anuran health assessments.

\section{Physiographic and Hydrogeologic Setting of the Study Areas}

The Death Valley National Park, Mojave National Preserve, and Joshua Tree National Park lie mostly within the Mojave Desert (fig. 1). The Mojave Desert is bordered on the west and southwest by the Sierra Nevada, San Gabriel, and San Bernardino Mountain ranges; on the north by the Great Basin Desert; on the east by the Colorado Plateau; and on the southeast by the Colorado-Sonoran Desert (fig. 1). Average annual precipitation in the Mojave Desert (fig. 1) is 137 millimeters (mm; Hereford and others, 2004), but large topographic differences create a variety of climate zones; annual precipitation ranges from as little as $30 \mathrm{~mm}$ on the desert floor, which has a minimum altitude of 86 meters (m) below sea level, to as much as about $300 \mathrm{~mm}$ at the top of bordering mountains that are more than $3,000 \mathrm{~m}$ above sea level. In the north and west, precipitation originates primarily from frontal winter storms off the Pacific Ocean, with some contribution from summer convective storms; whereas, in the south and east, precipitation originates primarily from summer convective storms (Hereford and others, 2004). Winter storms off the Pacific Ocean generally are of longer duration, resulting in greater infiltration, than summer precipitation (much of which evaporates before it can infiltrate).

Temperatures in the Mojave Desert are extreme, with the area that includes the Death Valley National Park, Mojave National Preserve, and Joshua Tree National Park (fig. 1) having annual temperature averages ranging from 16 degrees Celsius $\left({ }^{\circ} \mathrm{C}\right.$ ) to $24^{\circ} \mathrm{C}$ (Chung-MacCoubrey and others, 2008). Death Valley is the hottest, driest place in North America. The record high is $57^{\circ} \mathrm{C}$ and the record low is $-9^{\circ} \mathrm{C}$ for a single station in Death Valley (Death Valley National Park, National Park Service, 2006).

\section{Darwin Falls, Death Valley National Park}

Darwin Falls is near the western boundary of the Death Valley National Park (fig. 1). The following sections provide a general description of the Death Valley National Park and Darwin Falls study area, geology, and riparian habitat of the Darwin Falls study area, and the location of hydrological and biological surveys completed for this study.

\section{General Description}

Most of the Death Valley National Park lies within the northern part of the Mojave Desert, and the extreme northern part of the Death Valley National Park lies within the southwestern part of the Great Basin Desert (fig. 1). The park consists of 13,354 km² in California and Nevada (fig. 1). It is the lowest ( $86 \mathrm{~m}$ below sea level), driest (average annual rainfall of $49 \mathrm{~mm}$ on the desert floor), and hottest place in North America (July mean maximum temperature of $46{ }^{\circ} \mathrm{C}$; Death Valley National Park, National Park Service, 2006). A variety of habitats exist within the Death Valley National Park including salt flats, desert scrubs, desert woodlands, and coniferous forests (Death Valley National Park, National Park Service, 2006).

Darwin Falls is in Inyo County, California, near the western boundary of the Death Valley National Park, approximately 261 kilometers $(\mathrm{km})$ northeast of Los Angeles, and $8 \mathrm{~km}$ northeast of the town of Darwin (figs. 1 and 2). Darwin Falls lies on the northwest flank of the Argus Range west of Panamint Valley, south of the Darwin Plateau, and east of Darwin Hills and the Coso Range (fig. 2). Land-surface altitudes in the Darwin Falls drainage basin range from $804 \mathrm{~m}$ just downstream from Darwin Falls to 2,694 $\mathrm{m}$ at Maturango Peak in the Argus Range (fig. 2). The drainage basin above Darwin Falls comprises about $453 \mathrm{~km}^{2}$ and is drained by the Darwin Wash, which generally flows from south to north, and by several tributaries in the Coso and Argus Ranges (fig. 2).

\section{Geology}

Death Valley National Park lies on the western edge of the Basin and Range physiographic province (Bedinger and Sargent, 1989), which is characterized by extensionrelated northwest-striking mountain ranges and valley basins (Conners and Covington, 2004). Seismicity and structural and volcanic features, indicate that Death Valley has experienced a long and complex tectonic evolution that extends from the late Precambrian to the Holocene (Bedinger and Sargent, 1989).

Darwin Falls is in Darwin Canyon, which is carved into a complex suite of folded, faulted, uplifted, eroded, and metamorphosed late Paleozoic to Quaternary-aged rocks (figs. 3 and 4). The oldest rocks exposed in Darwin Canyon are the Permian sedimentary rocks (Pzs) that consist of sandstone, siltstone, limestone, conglomerate, shale, and calc-hornfels (fig. 3; Stone and others, 1998). The detailed geologic map of the Darwin Canyon area (fig. 4) shows that the Jurassicaged granitic rocks intrude the Darwin Canyon Formation. 


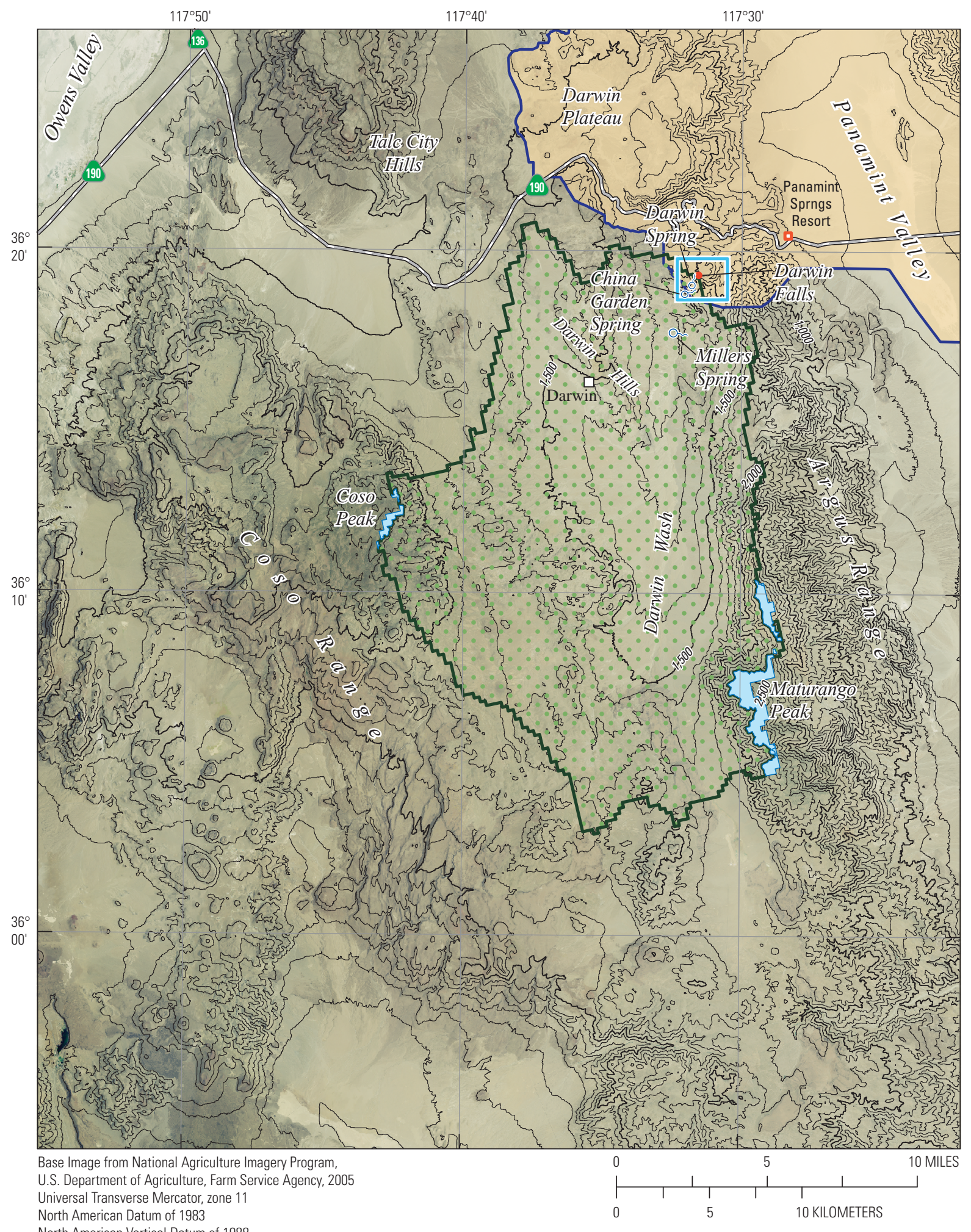

North American Vertical Datum of 1988

\section{EXPLANATION}

Death Valley National Park
Darwin Falls drainage-basin boundary, which was derived from a 270-meter digital elevation model
Darwin Falls study area shown on figure 4
Estimated recharge area based on stableisotope data
Land-surface altitude, in meters

on Spring

Figure 2. Darwin Falls drainage basin, Mojave Network Parks, California, 2005-06. 


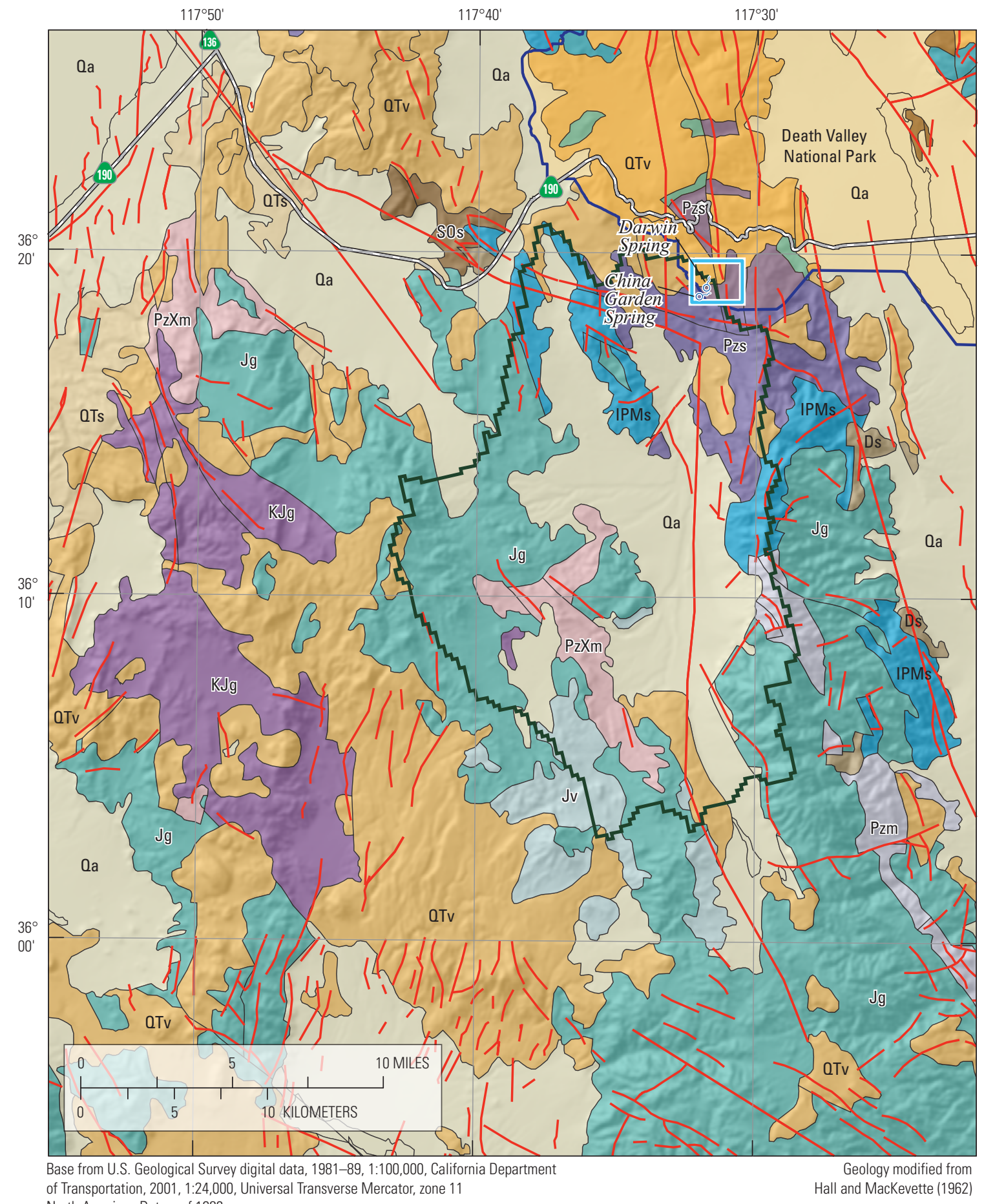

North American Datum of 1983

\section{EXPLANATION}

\section{Generalized geology (age/type)}

\begin{tabular}{|c|c|}
\hline Qa & Quaternary/Alluvium \\
\hline QTs & Quaternary-Tertiary/Sedimentary \\
\hline 01 & Quaternary-Tertiary/Volcanics \\
\hline$\overline{\mathrm{KJg}}$ & Cretaceous-Jurassic/Granitic \\
\hline $\mathrm{Jg}$ & Jurassic/Granitic \\
\hline J & Jurassic/Volcanic \\
\hline
\end{tabular}

Permian/Metamorphic

Paleozoic-Proterozoic/Metamorphic

Pennsylvainan-Mississippian/Sedimentary

Devonian/Sedimentary

Silurian-Ordovician/Sedimentary

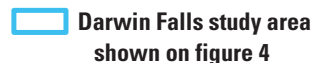

shown on figure 4

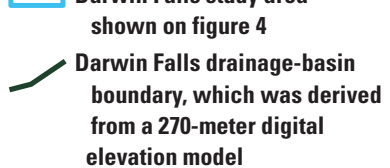

Death Valley National Park

_ Fault

or Spring

Figure 3. Geology of the Darwin Falls drainage basin and surrounding area, Mojave Network Parks, California, 2005-06. 


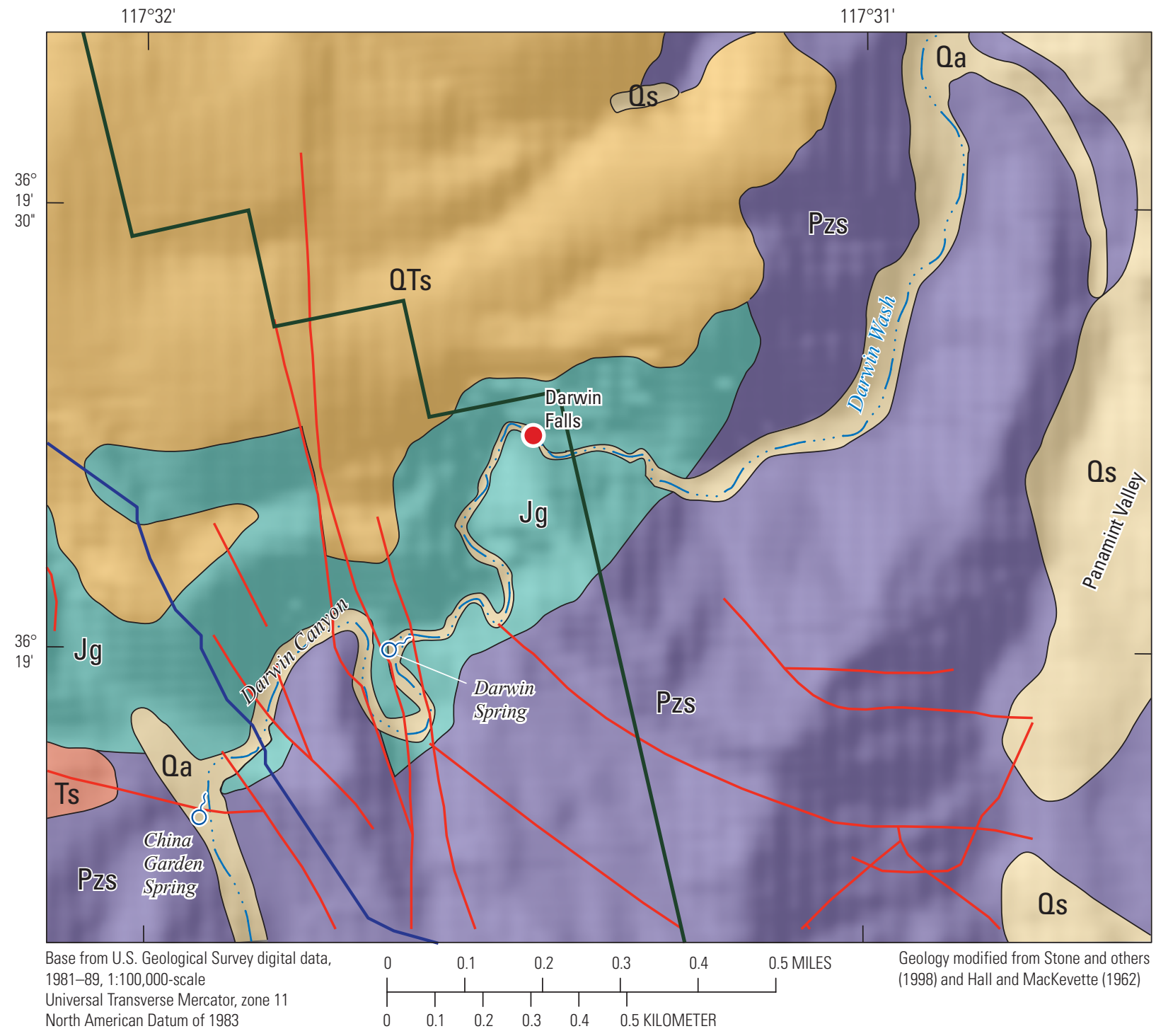

\section{EXPLANATION}

\begin{tabular}{|c|c|}
\hline & Generalized geology (age/type) \\
\hline Qa & Quaternary/Alluvium \\
\hline Os & Quaternary/Sedimentary \\
\hline QTs & Quaternary-Tertiary/Sedimentary \\
\hline Ts & Tertiary/Sedimentary \\
\hline $\mathrm{Jg}$ & Jurassic/Granitic \\
\hline PzS & Permian/Sedimentary \\
\hline
\end{tabular}

— Death Valley National Park boundary

Darwin Falls drainage-basin boundary,
which was derived from a 270-meter digital elevation model

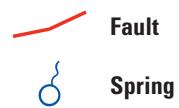

Figure 4. Geology of the Darwin Falls study area, Mojave Network Parks, California, 2005-06. 
Source, Discharge, and Chemical Characteristics of Selected Springs and Endemic Anuran Species, Mojave Network Parks

These intrusive rocks are composed of gabbro, granodiorite, and quartz monzonite (Hall and MacKevett, 1962). These rocks contain little primary permeability, but probably derive secondary permeability from faults and fractures (Hall and MacKevett, 1962). Pleistocene olivine-basalt flows, which are part of the Quaternary-Tertiary volcanics (QTv), overlie the intruded granitic rocks (fig. 3; Hall and MacKevett, 1962). Areas of low relief generally contain moderately permeable Pleistocene to Holocene-aged alluvium, stream gravel, and wash deposits of the Quaternary alluvium (Qa) that transmit recharge to underlying formations (fig. 4; Hall and MacKevett, 1962).

\section{Riparian Habitat}

Darwin Canyon strikes in a north-northwest direction at its highest altitude in the Argus Range (fig. 2) near China Garden Spring (fig. 4). North and downstream of China Garden Spring, the canyon abruptly turns in a northeast direction before descending to form Darwin Canyon that contains a series of falls and ultimately opens into Panamint Valley (fig. 4). Groundwater surfaces in a small pool at China Garden Spring and again in a smaller pool at Darwin Spring, perhaps because of nearby faults, before discharging into the canyon where it flows down a series of falls and forms a pool at the base of Darwin Falls before continuing to flow downstream in Darwin Wash (figs. 4 and 5A). Darwin Wash, one of only four perennial streams in the Death Valley National Park (fig. 1), continues to flow for a distance of about $1.6 \mathrm{~km}$ before infiltrating into sand in an open wash of creosote scrub at the mouth of the canyon. Willows (Salix spp.) and cottonwoods (Populis fremontii) are abundant at the large pool formed at the base of Darwin Falls and for the remainder of the downstream part of the canyon (fig. 5).

\section{Location of Hydrological and Biological Surveys}

Hydrological data were collected at selected sites along Darwin Canyon from China Garden Spring to about $0.4 \mathrm{~km}$ downstream from the base of Darwin Falls (fig. 6). Water continues to flow several hundred meters downstream, with the canyon widening into an open wash of creosote bush scrub before the stream disappears underground. Aquatic and biological surveys were completed from Darwin Falls downstream to where the canyon widens and water no longer flows (fig. 6). Biological surveys were focused on the western toad (Anaxyrus boreas; fig. 5D).

\section{Piute Spring, Mojave National Preserve}

Piute Spring is near the eastern boundary of the Mojave National Preserve (fig. 1). The following sections provide a general description of the Mojave National Preserve and the Piute Spring study area, the geology and riparian habitat of the Piute Spring study area, and the location of hydrological and biological surveys completed for this study.

\section{General Description}

The Mojave National Preserve is in southern California southeast of the Death Valley National Park, north of the Joshua Tree National Park, and west of the Colorado River (fig. 1). Mojave National Preserve consists of about 6,475 $\mathrm{km}^{2}$ representing a combination of the Great Basin, ColoradoSonoran, and Mojave Desert ecosystems (fig. 1; National Park Service, 2000). Land-surface altitude ranges from about $268 \mathrm{~m}$ in Baker to about 2,417 $\mathrm{m}$ in the Clark Mountains (fig. 1). Annual precipitation ranges from 89 to $254 \mathrm{~mm}$ with at least 25 percent of the precipitation arriving in summer monsoon thunderstorms (National Park Service, 2000). The Mojave National Preserve hosts a wide range of vegetation habitats including the following: creosote bush scrub (Larrea tridentada), mixed cactus (Cactaceae)-yucca (Yucca) scrub, and dense Joshua tree (Yucca brevifolia) woodland (National Park Service, 2000; Thomas and others, 2005). The higher altitude ranges in the Mojave National Preserve host the pinyon (Pinus edulis)-juniper (Juniperus) woodlands habitat (Stoffer, 2004; Thomas and others, 2005).

Piute Spring and Piute Creek are in Piute Canyon (fig. 9) near the eastern boundary of the Mojave National Preserve about $319 \mathrm{~km}$ west of Los Angles and $47 \mathrm{~km}$ northwest of Needles, Calif. (fig. 1). Piute Spring is the only spring in the Mojave National Preserve that is the source for a perennial stream. The spring is on the southern end of the Piute Range in Piute Canyon (fig. 7) at an altitude of $914 \mathrm{~m}$. The Piute Spring drainage basin consists of approximately $587 \mathrm{~km}^{2}$. The landsurface altitude of the canyon decreases from about $1,050 \mathrm{~m}$ in the Piute Range to about $800 \mathrm{~m}$ where it widens into Piute Valley (fig. 7).

\section{Geology}

The Mojave National Preserve is within the central area of the Basin and Range physiographic province (Bedinger and Sargent, 1989), and is characterized by extension-related block faulting and right-lateral faulting associated with the San Andreas Fault (Covington, 2003). From the Proterozoic to the Holocene, rocks in the area have undergone repeated episodes of deformation, intrusion, deposition, and erosion (fig. 8).

Piute Canyon is carved into a suite of Proterozoic to Quaternary-aged rock that has been repeatedly faulted since the Mesozoic (figs. 8 and 9; Nielson and others, 1987). The oldest rocks forming the basement complex beneath Piute Canyon are Proterozoic metamorphic rocks $(\mathrm{Xm})$ intruded by Cretaceous-Jurassic granite (KJg), and Miocene plugs and laccoliths (figs. 8 and 9; Nielson and others, 1987). Mioceneaged volcanic deposits with interbedded sedimentary rocks (Tvs; fig. 8) unconformably overlie the basement complex. These units contain little primary permeability, but possess significant secondary permeability that is derived from weathering and north-striking normal faults and north-northeaststriking transverse faults that traverse the Piute Range (fig. 7) and a large part of Piute Canyon (figs. 8 and 9; Freiwald, 

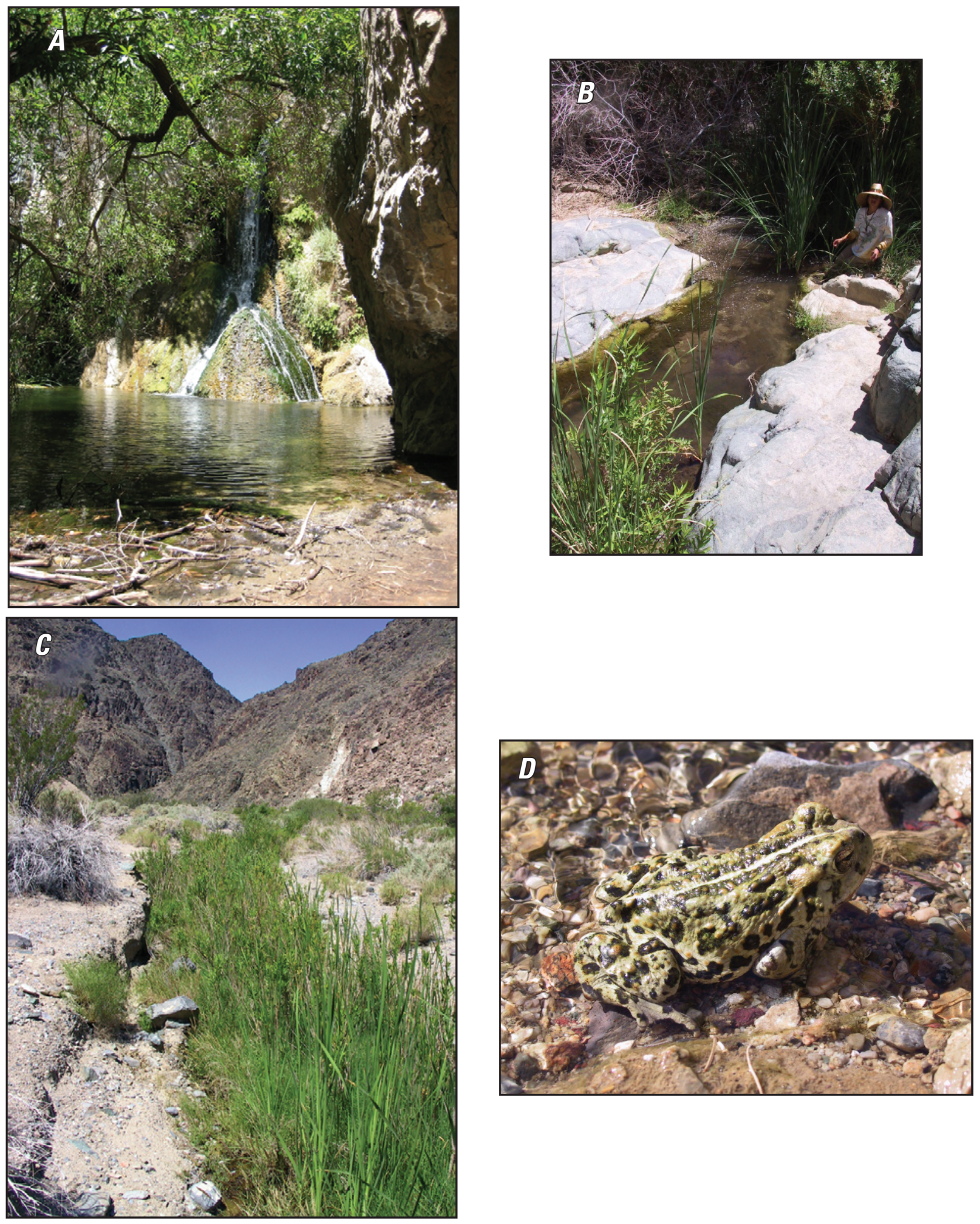

Figure 5. Habitat and species of interest at Darwin Falls in the Mojave Network Parks, California, 2005-06. A, Darwin Falls and pool at base of Darwin Falls, looking northwest, upstream. B, Darwin Wash, about 100 meters downstream of Darwin Falls, looking southeast, downstream. $C$, Darwin Wash, about 1 kilometer downstream of Darwin Falls, looking southwest, upstream. $D$, Adult western toad (Anaxyrus boreas). 


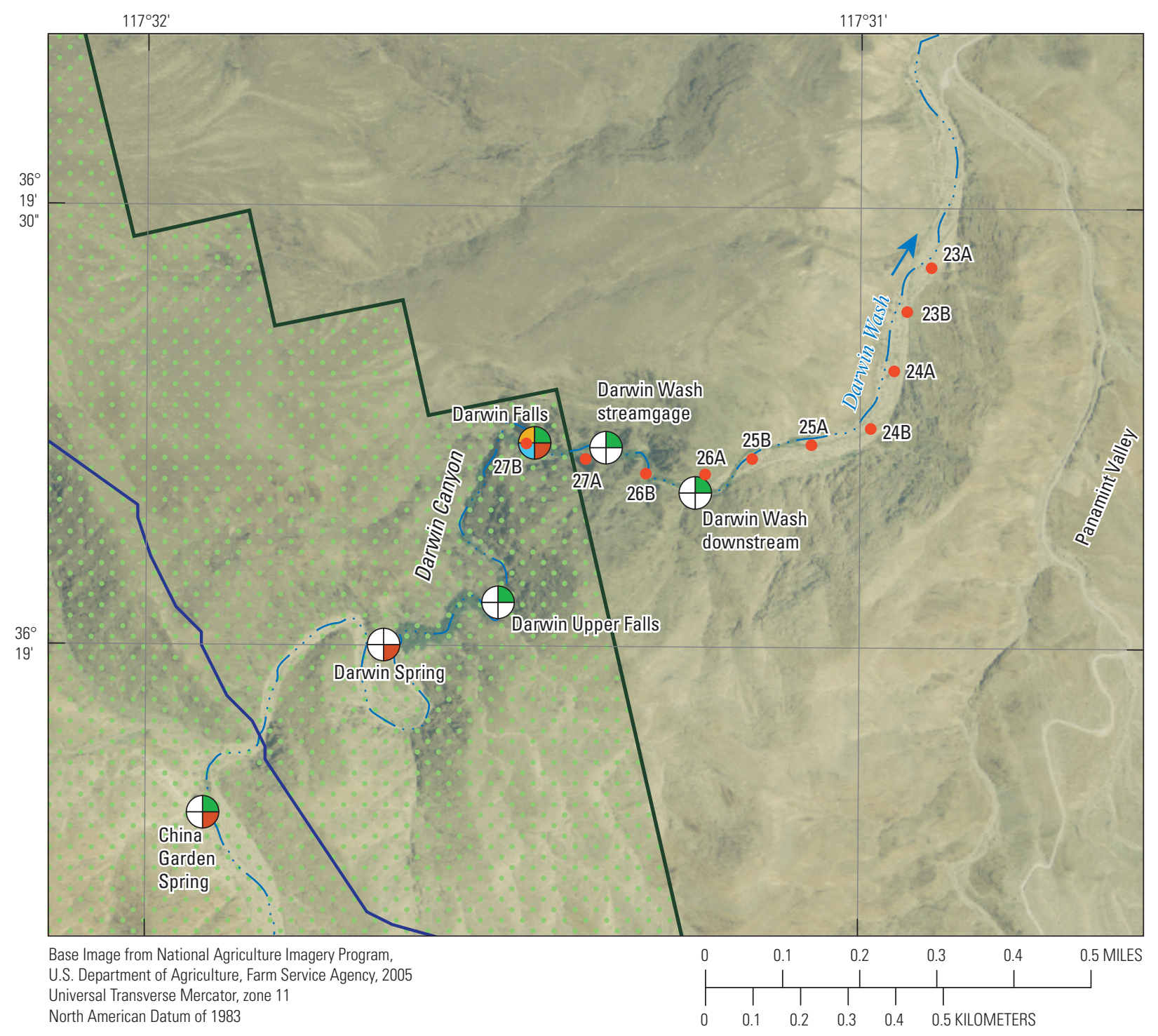

\section{EXPLANATION}

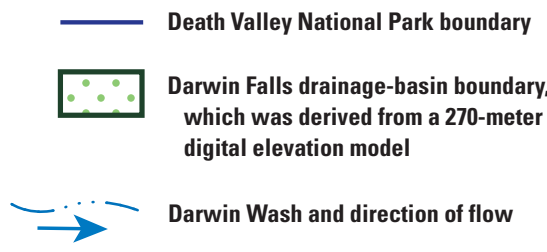

U.S. Geological Survey monitoring site-
Filled part of circle shows type of
sampling at each site
27A Downstream starting point and identifier for the 125-meter reach (see Table 3-1)

Figure 6. Survey reaches for hydrological and biological data collection at the Darwin Falls study area, Mojave Network Parks, California, 2005-06. 


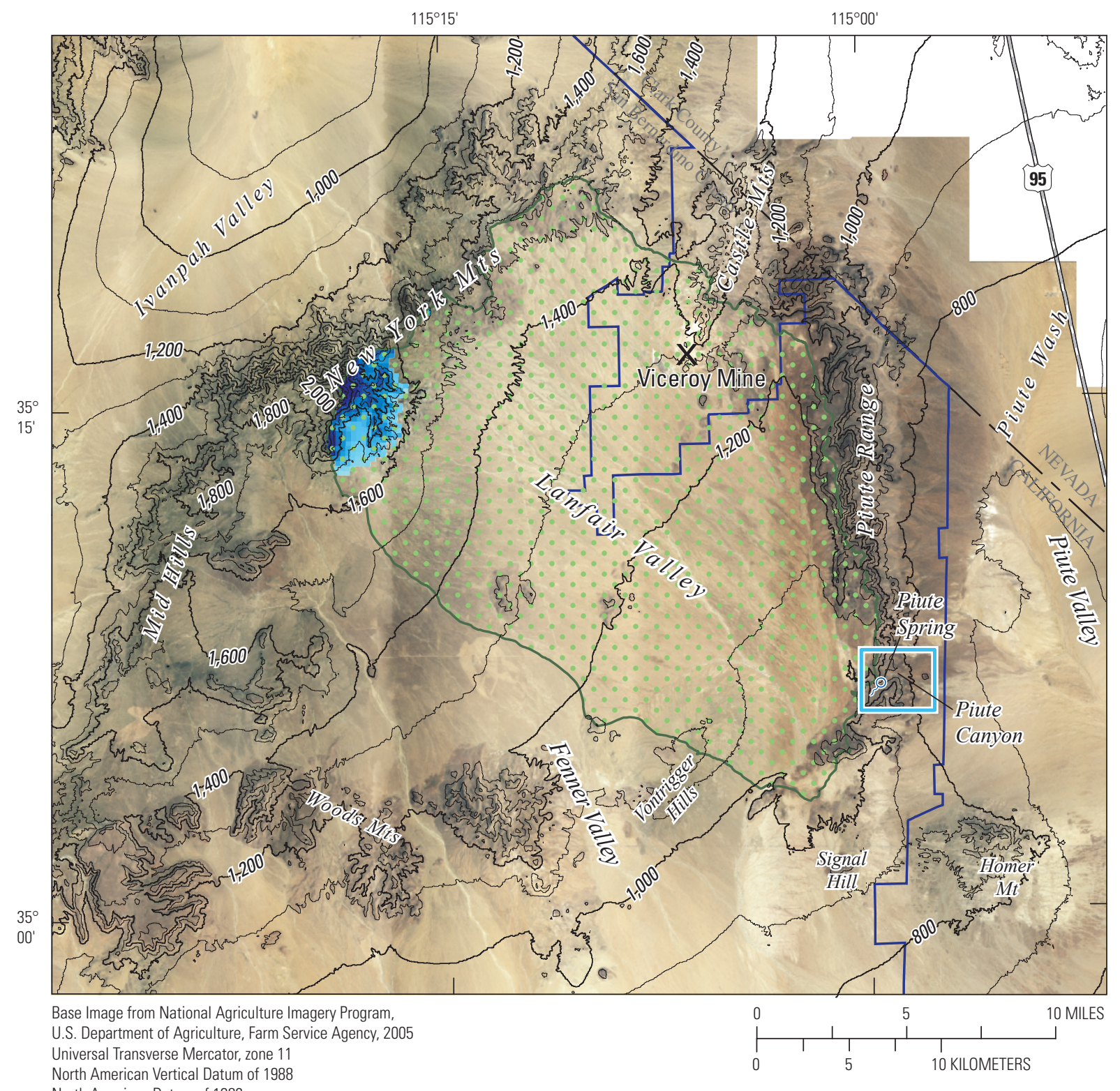

EXPLANATION

Mojave National Preserve boundary

Piute Spring drainage-basin boundary, which was derived from a 270-meter digital elevation model
Piute Spring study area shown on figure 9

Estimated recharge area based on stable-isotope data
Land-surface altitude, in meters

On Spring

Figure 7. Piute Spring drainage basin, Mojave Network Parks, California, 2005-06. 


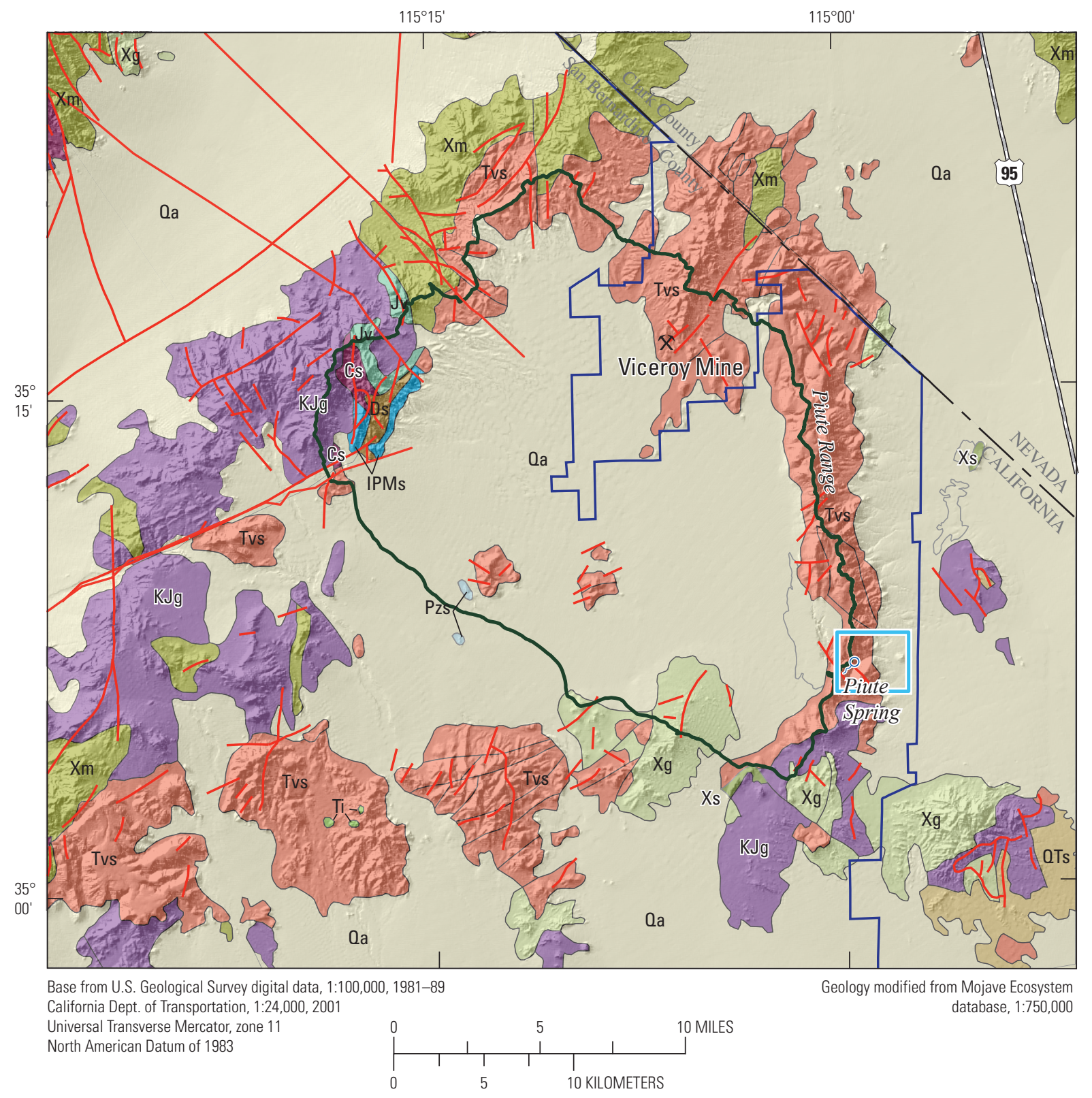

\section{EXPLANATION}

\section{Generalized geology (age/type)}

\begin{tabular}{|c|c|}
\hline Qa & Quaternary/Alluvium \\
\hline QTs & Quaternary-Tertiary/Sedimentary \\
\hline Tvs & Tertiary/Volcanic, volcanic sedimentary \\
\hline $\mathrm{Ti}$ & Tertiary/Intrusive \\
\hline & Cretaceous-Jurassic/Granitic \\
\hline $\mathrm{Jv}$ & Jurassic/Volcanic \\
\hline PMs & Pennsylvanian-Mississippian/Sedimentary \\
\hline Ds & Devonian/Sedimentary \\
\hline
\end{tabular}

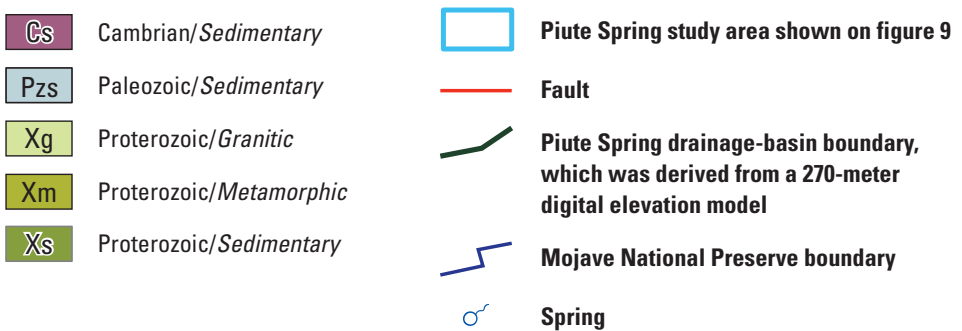

Figure 8. Geology of the Piute Spring drainage basin and surrounding area, Mojave Network Parks, California, 2005-06. 


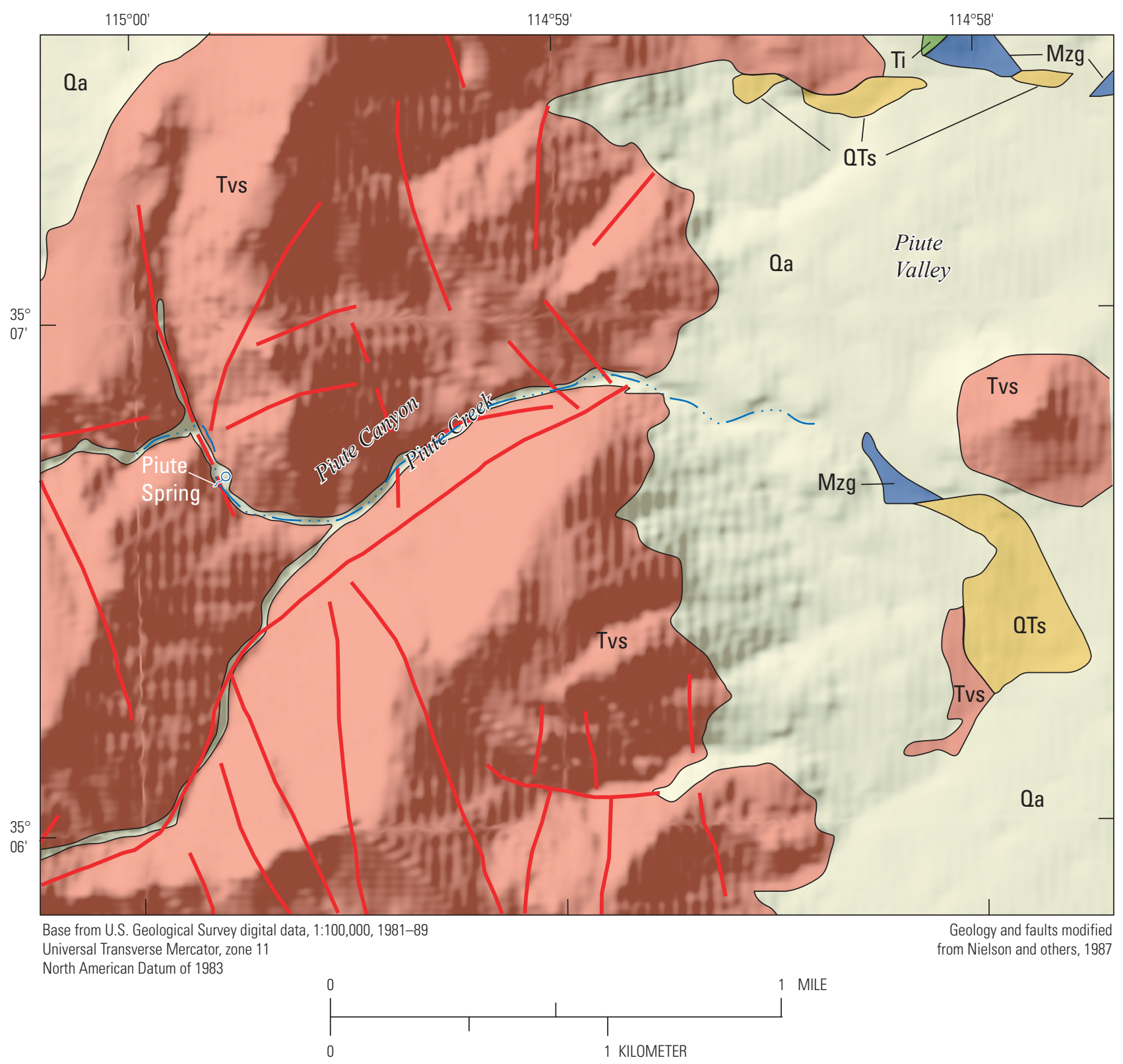

\section{EXPLANATION}

\begin{tabular}{|c|c|}
\hline & Seneralized geology (age/type) \\
\hline Qa & Quaternary/Alluvium \\
\hline QTs & Quaternary-Tertiary/Sedimenta \\
\hline
\end{tabular}

\begin{tabular}{llll}
\hline Tvs & Tertiary/Volcanic sedimentary & & Fault \\
\hline Ti & Tertiary/Intrusive & or & Spring \\
\hline Mzg & Mesozoic/Granitic & & \\
\hline
\end{tabular}

Figure 9. Geology of the Piute Spring study area, Mojave Network Parks, California, 2005-06. 
1984). The areas of low relief through Piute Canyon contain alluvial deposits, stream gravels, wash deposits, and slope wash of Qa (figs. 8 and 9).

The Piute Canyon structure predominately trends along faults (fig. 9; Nielson and others, 1987) indicating that the fault system played a role in the development and topography of the canyon. Faults in the Piute Canyon area are northstriking normal faults (fig. 9). North-northeast-striking transverse faults accompany the normal faults with one traversing through the Piute Range (figs. 7 and 8 ) and a large part of Piute Canyon (fig. 9).

\section{Riparian Habitat}

The Piute Canyon drainage is nearly perpendicular to the regional drainage and is carved from west to east through the Piute Range. Groundwater first emerges in the canyon at Piute Spring and flows into Piute Creek along the narrow canyon that widens to the east (fig. 9). Piute Creek (fig. 9) flows perennially, except for a short intermediate reach where flow disappears into the gravel stream channel before reemerging about $0.16 \mathrm{~km}$ downstream, and continues flowing until it infiltrates into Piute Valley (fig. 9) at the mouth of the canyon about $1.9 \mathrm{~km}$ downstream of Piute Spring (fig. 9). Discharge in Piute Creek increases downstream of Piute Spring (fig. 9), indicating addition from groundwater seepage as the stream flows through the canyon. Freiwald (1984) estimated that groundwater outflow from Lanfair Valley at Piute Spring (fig. 7) ranged from about 123,000 to 777,000 cubic meters per year $\left(\mathrm{m}^{3} / \mathrm{yr}\right)$.

A high intensity fire on September 4, 2004, burned through most of Piute Creek with only the tallest cottonwood (Populus fremontii) trees escaping crown fire (Dingman, 2004; Harris and Harris, 2009). Although the fire burned most of the vegetation along Piute Creek, the vegetation surrounding the Piute Spring orifice escaped fire damage. Prefire vegetation habitat consisted of streamside creosote bush scrub (Larrea tridentate), catclaw acacia (Acacia greggii), willow species (Salix spp.), cottonwood (Populus fremontii), desert willow (Chilopsis linearis), and a narrow leaf willow (Salix exigua) understory (fig. 10A; Hazard and Rotenberry, 1996). When hydrological and biological surveys for this study began in May 2005, vegetation in the study area was already starting to reestablish itself. The vegetation consisted of willow (Salix L.), cottonwood (Populus fremontii), sedge (Cyperaceae), cattail (Carex typhina), and mulefat (Baccharis salicifolia) (fig. $10 B, C$, and $D$ ).

\section{Location of Hydrological and Biological Surveys}

Hydrological and biological data were collected at selected sites along Piute Canyon from Piute Spring to about $1.2 \mathrm{~km}$ downstream (fig. 11). Biological surveys were focused on the red-spotted toad (Anaxyrus punctatus), which was the only amphibian present at this site (fig. 10E). Piute Spring's orifice was difficult to access during the first year of the study because of dense, low-lying vegetation; however, during the second year of this study, a flood removed much of this dense vegetation, allowing access to the spring's orifice.

\section{Fortynine Palms Oasis, Joshua Tree National Park}

Fortynine Palms Oasis is in the northwestern part of the Joshua Tree National Park (fig. 1). The following sections provide a general description of the Joshua Tree National Park and the Fortynine Palms Oasis study area, the geology and riparian habitat of the Fortynine Palms Oasis study area, and the location of hydrological and biological surveys completed for this study.

\section{General Description}

The Joshua Tree National Park is in Riverside County and San Bernardino County, Calif., about $220 \mathrm{~km}$ east of Los Angeles, and covers approximately $3,240 \mathrm{~km}^{2}$ (fig. 1; National Park Service, 2000). The southern and eastern parts of the Joshua Tree National Park at altitudes below about $910 \mathrm{~m}$ are within the Colorado-Sonoran Desert, and the northern part of the Joshua Tree National Park is within the Mojave Desert (fig. 1). Land-surface altitudes range from about $543 \mathrm{~m}$ along the southern boundary of the park to 1,772 $\mathrm{m}$ in the Little San Bernardino Mountains (fig. 1; National Park Service, 2000). Daytime average maximum temperatures range from $40{ }^{\circ} \mathrm{C}$ in July to $0{ }^{\circ} \mathrm{C}$ in December and January; in the latter two months, freezing temperatures at night are common (National Park Service, 2000). The average annual precipitation rates simulated by Nishikawa and others (2004) average about $250 \mathrm{~mm}$ at the higher altitudes to about $100 \mathrm{~mm}$ at the lower altitudes near Twentynine Palms (fig. 1). Vegetation includes California juniper (Juniperus californica) and pinyon pine (Pinus monophylla) in the higher altitudes of the Little San Bernardino Mountains; ocotillo (Fouquieria splendens) and cholla cactus (Cylindropuntia fulgida) in the southeast side of the Colorado-Sonoran Desert; Joshua trees (Yucca brevifolia) in the northern end; and dense stands of Joshua tress (Yucca brevifolia) in the western part of the Joshua Tree National Park (fig. 1; National Park Service, 2000).

Fortynine Palms Oasis is in Fortynine Palms Canyon in the northwestern part of the Joshua Tree National Park, on the western edge of the Pinto Mountains, about $5 \mathrm{~km}$ southwest of Twentynine Palms, California (figs. 1 and 12). Land-surface altitudes in Fortynine Palms Canyon decrease from south to north (fig. 12). The oasis is situated near the lower end of the canyon at an altitude of about $861 \mathrm{~m}$ (fig. 12). The Fortynine Palms Oasis drainage basin (fig. 12) is approximately $12.4 \mathrm{~km}^{2}$. 


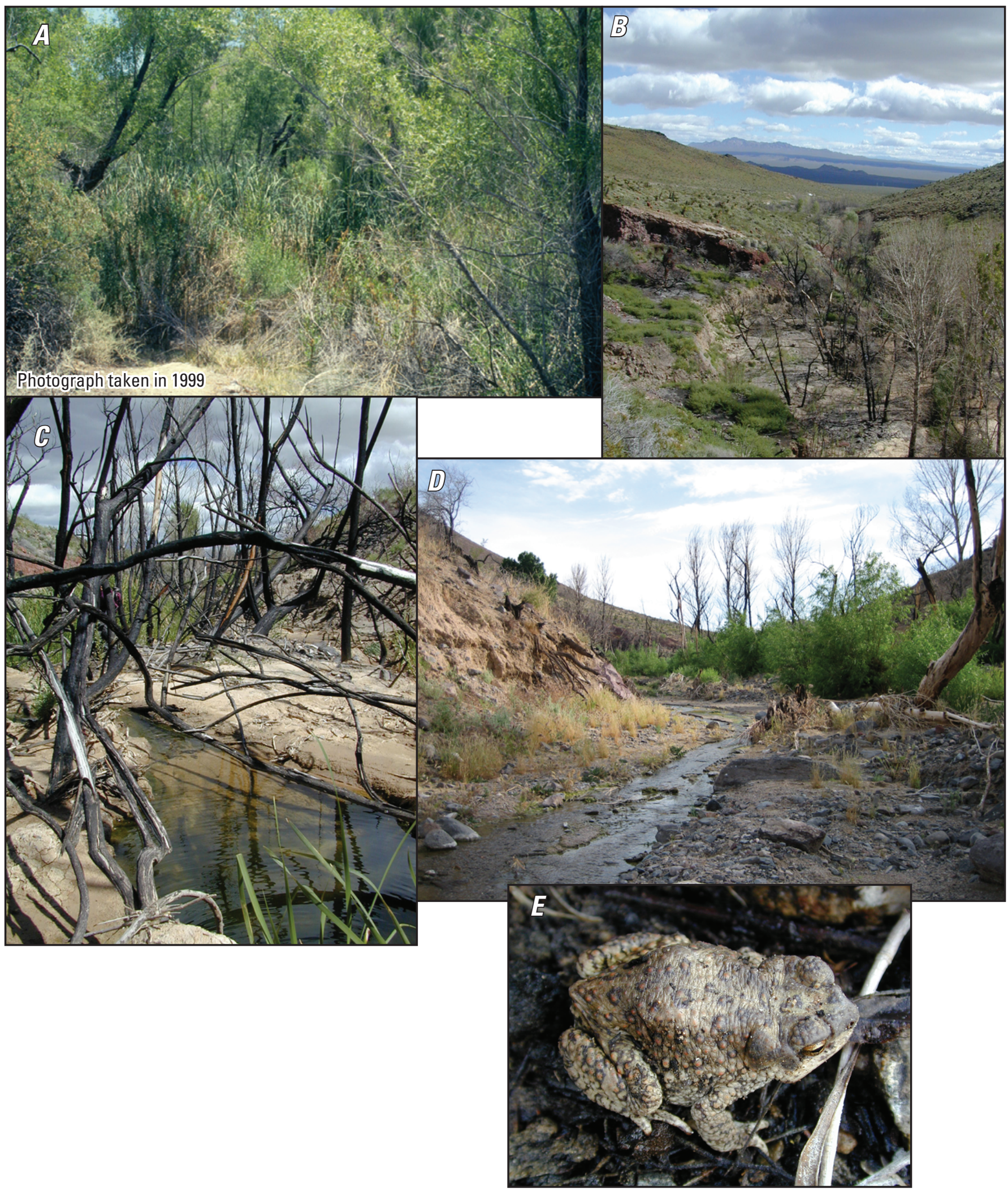

Figure 10. Habitat and species of interest at Piute Spring in the Mojave Network Parks, California, 2005-06. A, Piute Canyon in 1999 documenting the habitat conditions before the 2004 fire. B, Piute Canyon in 2005, looking northeast, downstream. C, Piute Creek in 2005, looking northeast, downstream. D, Piute Creek in 2005, looking southwest, upstream. E, Adult red-spotted toad (Anaxyrus punctatus). 


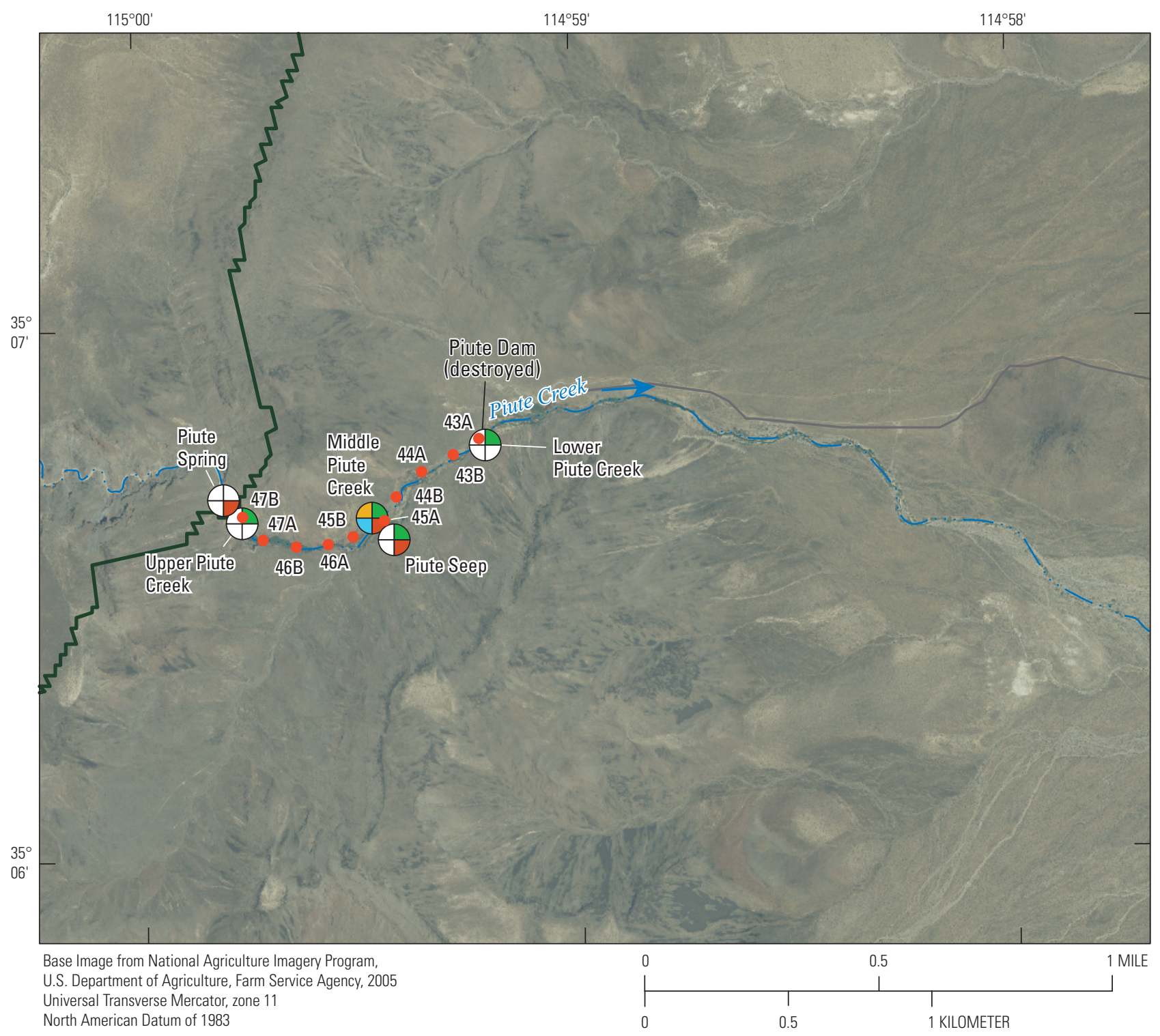

\section{EXPLANATION}

Piute Spring drainage-basin boundary,
which was derived from a 270-meter digital elevation model

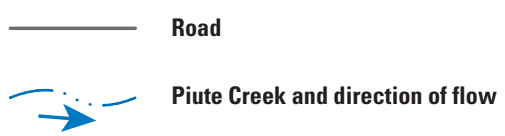

U.S. Geological Survey monitoring siteFilled part of circle shows type of sampling at each site

Air temperature
Discharge Water temperature Water quality
47A

Downstream starting point and identifier for the 125-meter reach (see Table 3-1)

Figure 11. Survey reaches for hydrological and biological data collection at the Piute Spring study area, Mojave Network Parks, California, 2005-06. 


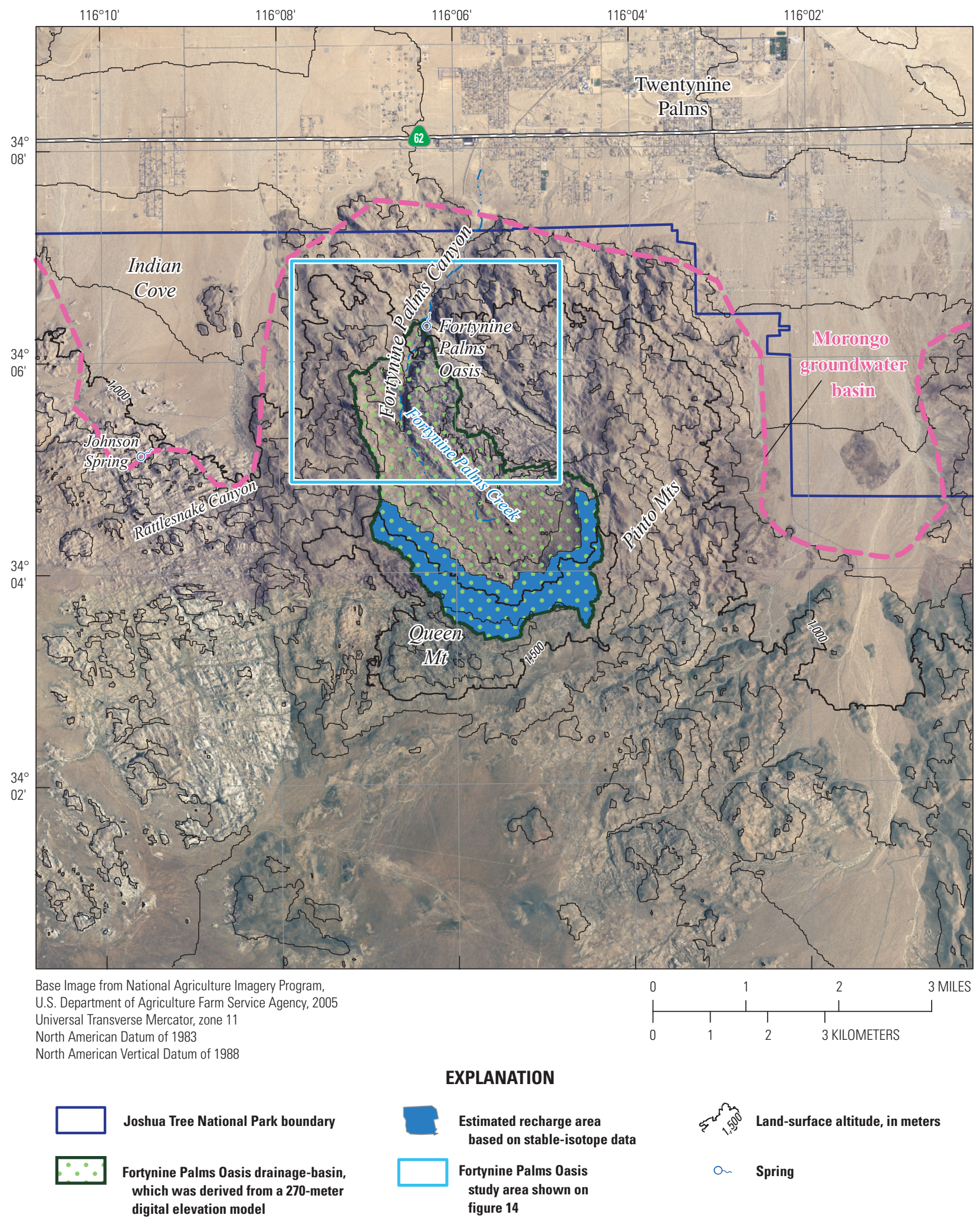

Figure 12. Fortynine Palms Oasis drainage basin, Mojave Network Parks, California, 2005-06. 


\section{Geology}

Joshua Tree National Park is at the eastern end of the Transverse Range physiographic province that is characterized by transtension-related west-striking mountain ranges and valleys extending $523 \mathrm{~km}$ west to the Pacific Ocean (fig. 1; Trent, 1984). The oldest rocks exposed in the area of Fortynine Palms Canyon are foliated Proterozoic metamorphic rocks consisting of gneiss, schist, and quartzite (Xm; fig. 13; Trent, 1984). The Jurassic granite unit (Jmz), which consists of porphyritic quartz monzonite, and the Cretaceous-Jurassic granite unit (KJg), which consists of garnet- and muscovitebearing monzogranite, intrude the Proterozoic basement near Fortynine Palms Canyon (fig. 13). These rocks are similarly impermeable except along fractures and joints (fig. 13; Weir and Bader, 1963).

\section{Riparian Habitat}

Fortynine Palms Oasis is sustained by infiltration that occurs through the joints and fractures (fig. 14) in the igneous rocks upgradient of the oasis (Wier and Bader, 1963). These structures channel water downgradient to the Fortynine Palms Oasis (fig. 14) where the infiltrated water discharges from a spring beneath a shallow, 1.5 -m-deep perennial upper pool (fig. 15B). Discharge from the spring is sufficient to maintain perennial flow from the pool and form two smaller downstream pools. For this report, the pools are referred to in downstream order with the names of Upper Pool, Middle Pool, and Lower Pool (fig. 16). Vegetation at the Fortynine Palms Oasis (fig. 12) includes native California fan palms (Washingtonia filifera), cottonwood (Populus fremontii), willow species (Salix spp.), and honey mesquite (Prosopis glandulosa)

\section{Location of Hydrological and Biological Surveys}

Hydrological data were collected at the Upper, Middle, and Lower Pools of the Fortynine Palms Oasis (fig. 16). Biological surveys were initially completed throughout the wetted reach at the oasis and were later extended upstream of the Upper Pool (fig. 16). Biological surveys focused on the red-spotted toad (Anaxyrus punctatus) and the California treefrog (Pseudacris cadaverina; figs. $15 D$ and $15 E$ ), the two endemic anuran species present at this site.

\section{Anuran Ecology}

The western toad (Anaxyrus boreas; formerly Bufo boreas), red-spotted toad (Anaxyrus punctatus; formerly Bufo punctatus), and California treefrog (Pseudacris cadaverina) are the three endemic anuran species that are present at one or more of the springs in this study. General information about these three species is given below.

\section{Western Toad (Anaxyrus boreas)}

Western toads (Anaxyrus boreas) can be located throughout most of western North America, including western Canada and parts of southeastern Alaska (Wright and Wright, 1949; Stebbins, 2003). Population declines are occurring within Colorado, Wyoming, Nevada, New Mexico, Oregon, Utah, and the Sierra Nevada (Stebbins and Cohen, 1995; Stebbins, 2003). Typical breeding behavior for western toads consists of surfacing from their hibernation sites, migrating to where surface water is present, and breeding. At Darwin Falls, the perennial water supports western toads year round. Eggs are laid in strings, consisting of double rows, with approximately 12,000 eggs per clutch (Wright and Wright, 1949). Eggs are reported to hatch within 3-10 days (Leonard and others, 1993), and tadpoles sustain themselves on detritus and algal matter until metamorphosis occurs in 30-45 days (Wright and Wright, 1949). Tadpoles generally are present in warmer, more shallow parts of the water column during the day and retreat to the deeper parts of the water column at night. Observations during this study indicate that newly metamorphosed frogs tend to cluster around the water's edge day and night, whereas juveniles and adults typically are more active at night. Toads become reproductively mature, in most non-desert species, in 3-6 years (Carey, 1976; Carey and others, 2001). At reproductive maturity, snout-vent length (SVL) ranges from 60-125 mm. Western toads are known to have a long life span (Muths and Corn, 2000), and recaptures in Colorado were determined to be at least 9 years old (Campbell, 1976). The western toad is endemic to Darwin Falls, but is introduced in other areas of the Death Valley National Park (Stebbins, 2003).

\section{Red-Spotted Toad (Anaxyrus punctatus)}

Red-spotted toads (Anaxyrus punctatus) occur from southwestern Kansas and Oklahoma to southeastern California and northwestern Mexico (Stebbins, 2003), and persist in a broad range of habitats (Dayton and Fitzgerald, 2006). The species occurs at Piute Spring and Fortynine Palms Oasis, and was present at Darwin Falls until the early 1980s (fig. 1).

Red-spotted toads tend to breed from April to June (Tevis, 1966). Eggs are laid singly at the bottom of pools, with approximately $30-5,000$ eggs per clutch that usually hatch within 5 days (Tevis, 1966). Red-spotted toad tadpoles are dark black in color and likely to absorb the most heat from the sun (Miller and Stebbins, 1964; Tevis, 1966). Time to metamorphosis is typically 30-60 days (Tevis, 1966), at which time toads exhibit clustering behavior around the water's edge. The life span of the red-spotted toad has been reported at 6 years, with reproductive maturity occurring at approximately 2 years (Sullivan and Fernandez, 1999). At reproductive maturity, SVL ranges from 52-66 $\mathrm{mm}$ for females and $47-63 \mathrm{~mm}$ for males (Sullivan and Fernandez, 1999). 


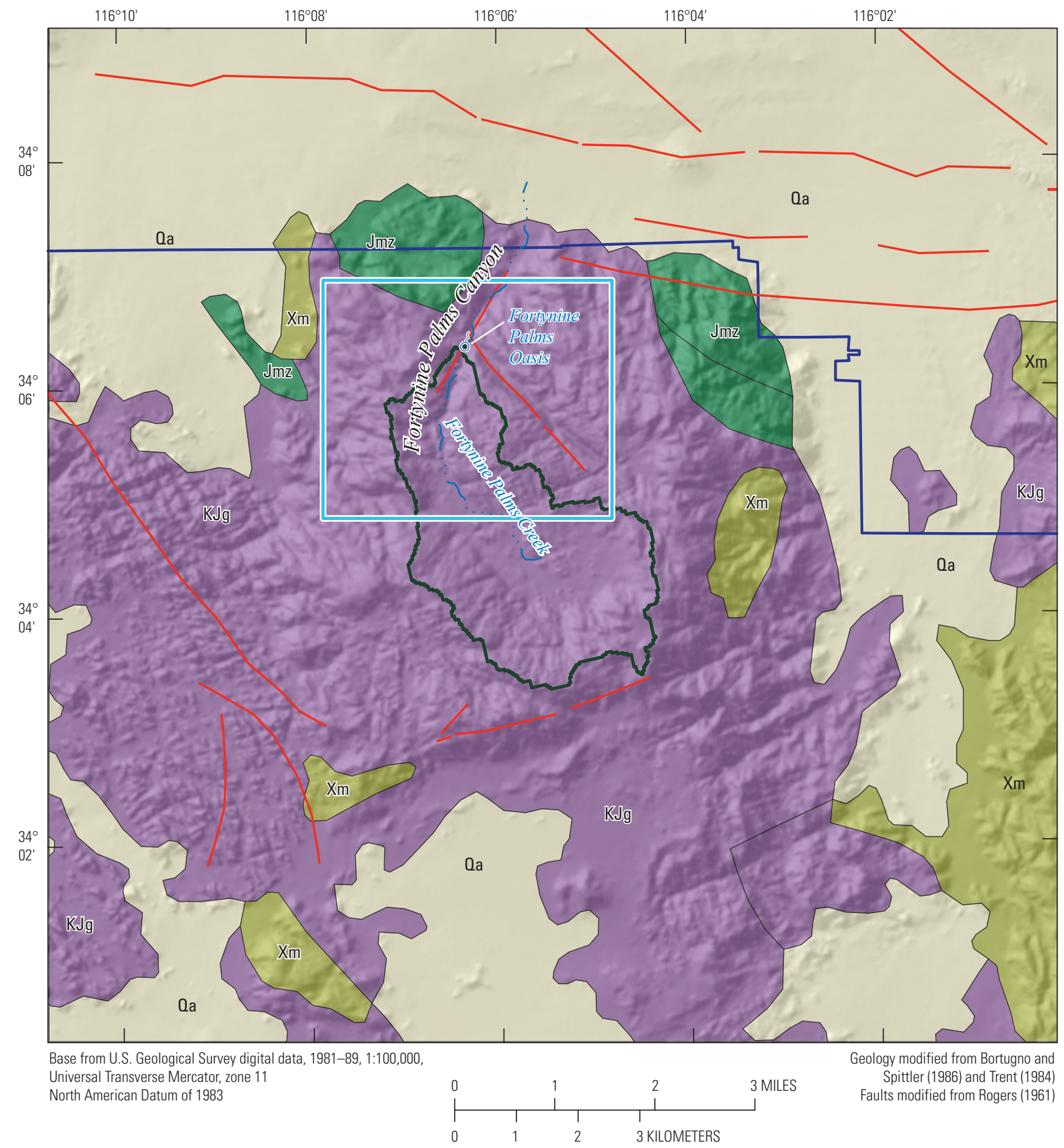

\begin{tabular}{|c|c|}
\hline & eneralized geology (age/type) \\
\hline Qa & Quaternary/Alluvium \\
\hline Jg & Cretaceous-Jurassic/Granitic \\
\hline Jmz & Jurassic/Granitic \\
\hline $\mathrm{Xm}$ & Proterozoic/Metamorphic \\
\hline
\end{tabular}

EXPLANATION
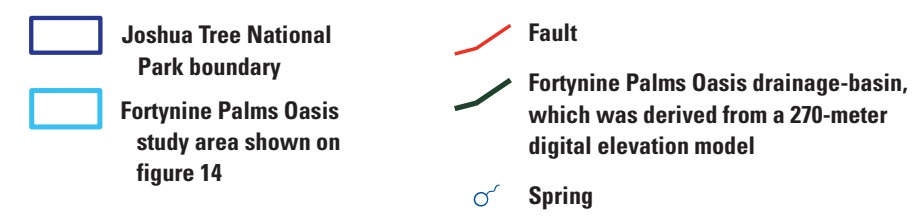

Figure 13. Geology of the Fortynine Palms Oasis drainage basin and surrounding area, Mojave Network Parks, California, 2005-06. 


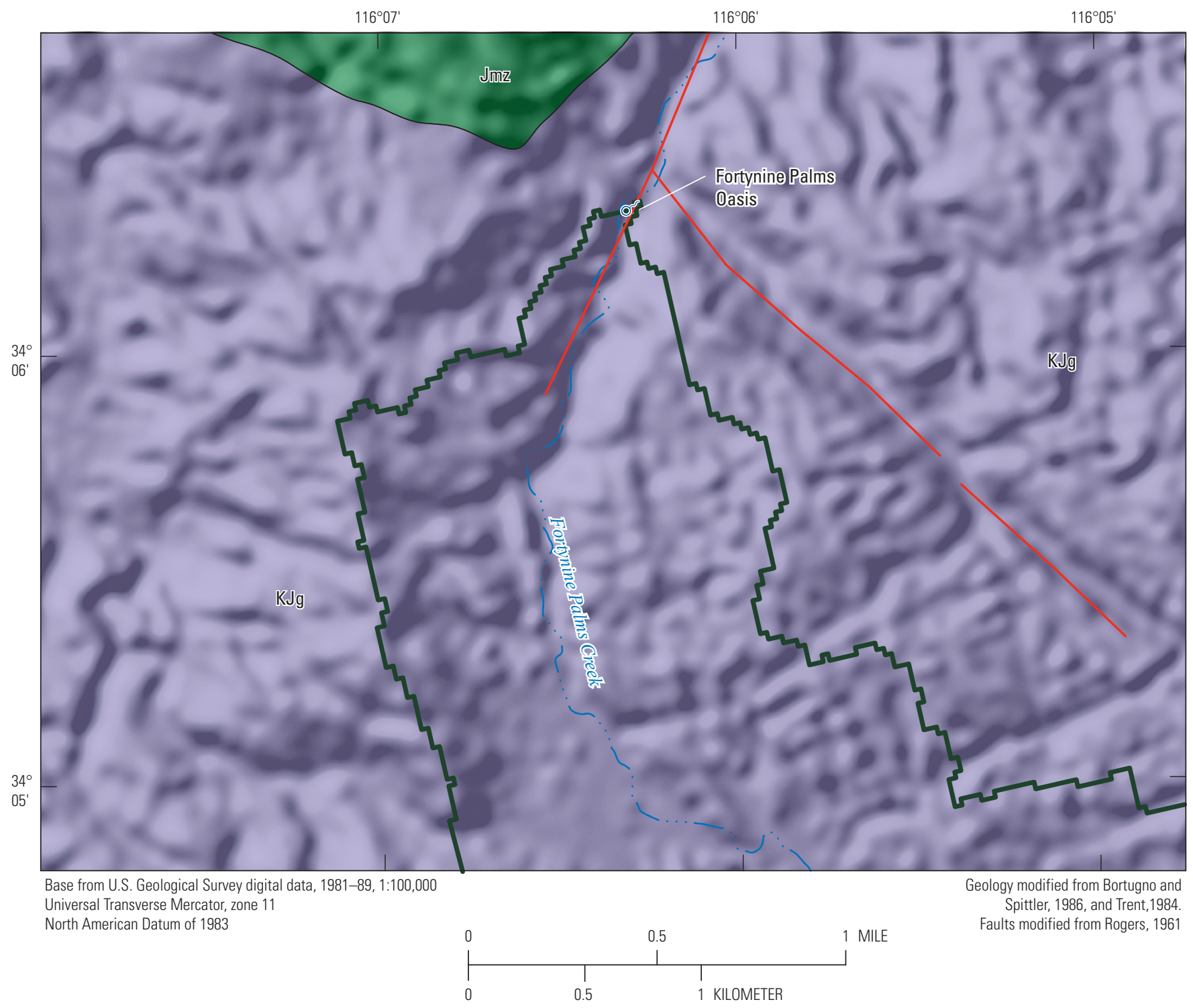

\section{EXPLANATION}
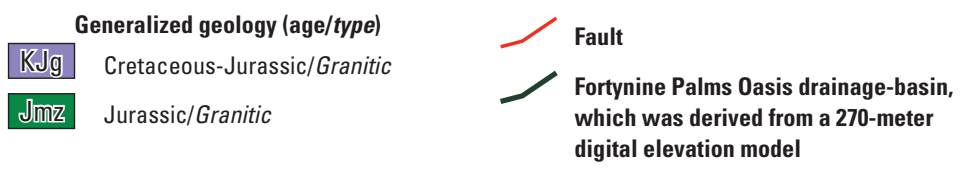

$\sigma^{\prime}$ Spring

Figure 14. Geology of the Fortynine Palms Oasis study area, Mojave Network Parks, California, 2005-06. 


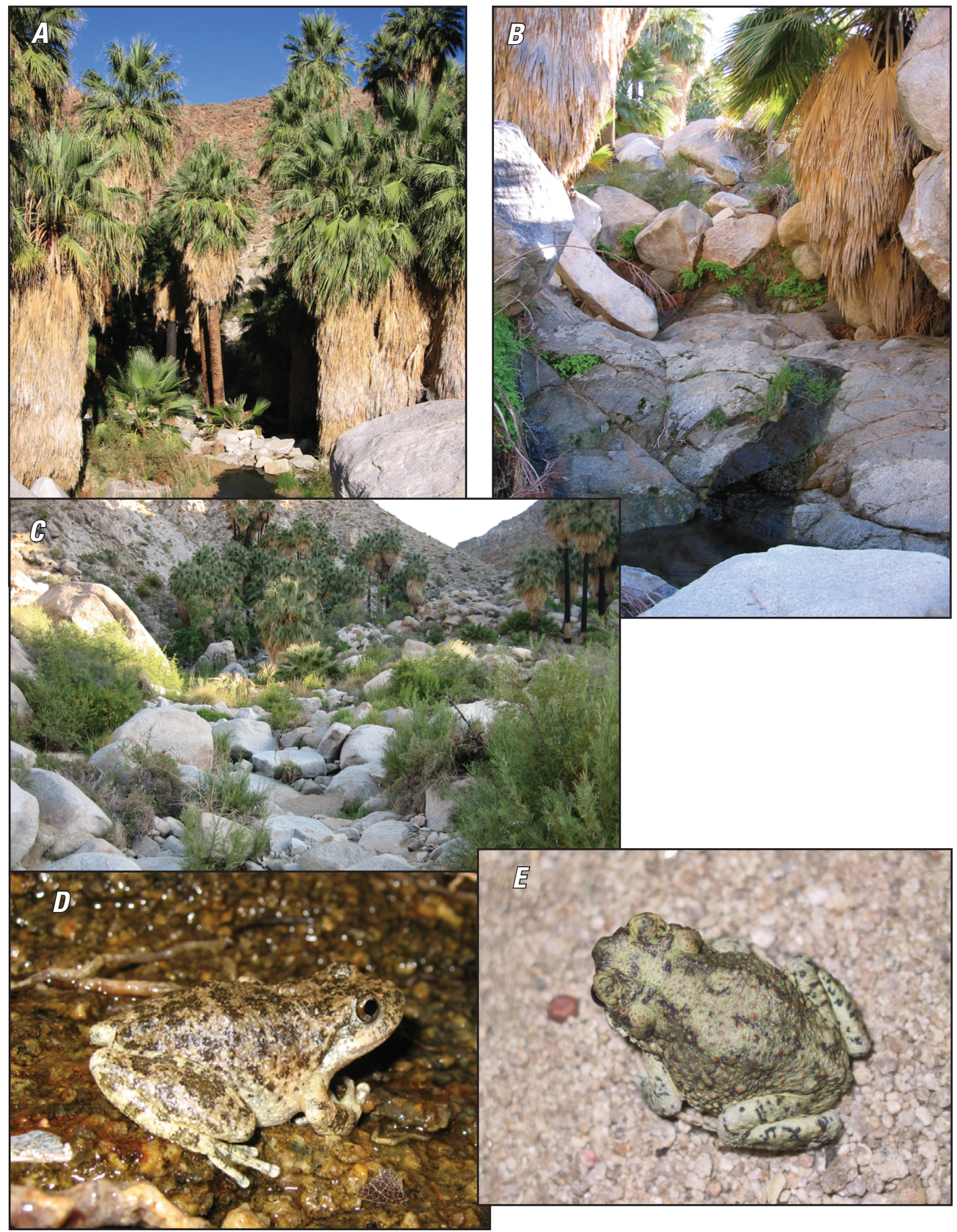

Figure 15. Habitat and species of interest at Fortynine Palms Oasis in the Mojave Network Parks, California, 2005-06. A, Fortynine Palms Oasis, looking northeast, downstream. $B$, Upper Pool at Fortynine Palms Oasis, looking southwest, upstream. $C$, Fortynine Palms Oasis, looking southwest, upstream. D, Adult California treefrog (Pseudacris cadaverina). E, Adult red-spotted toad (Anaxyrus punctatus). 


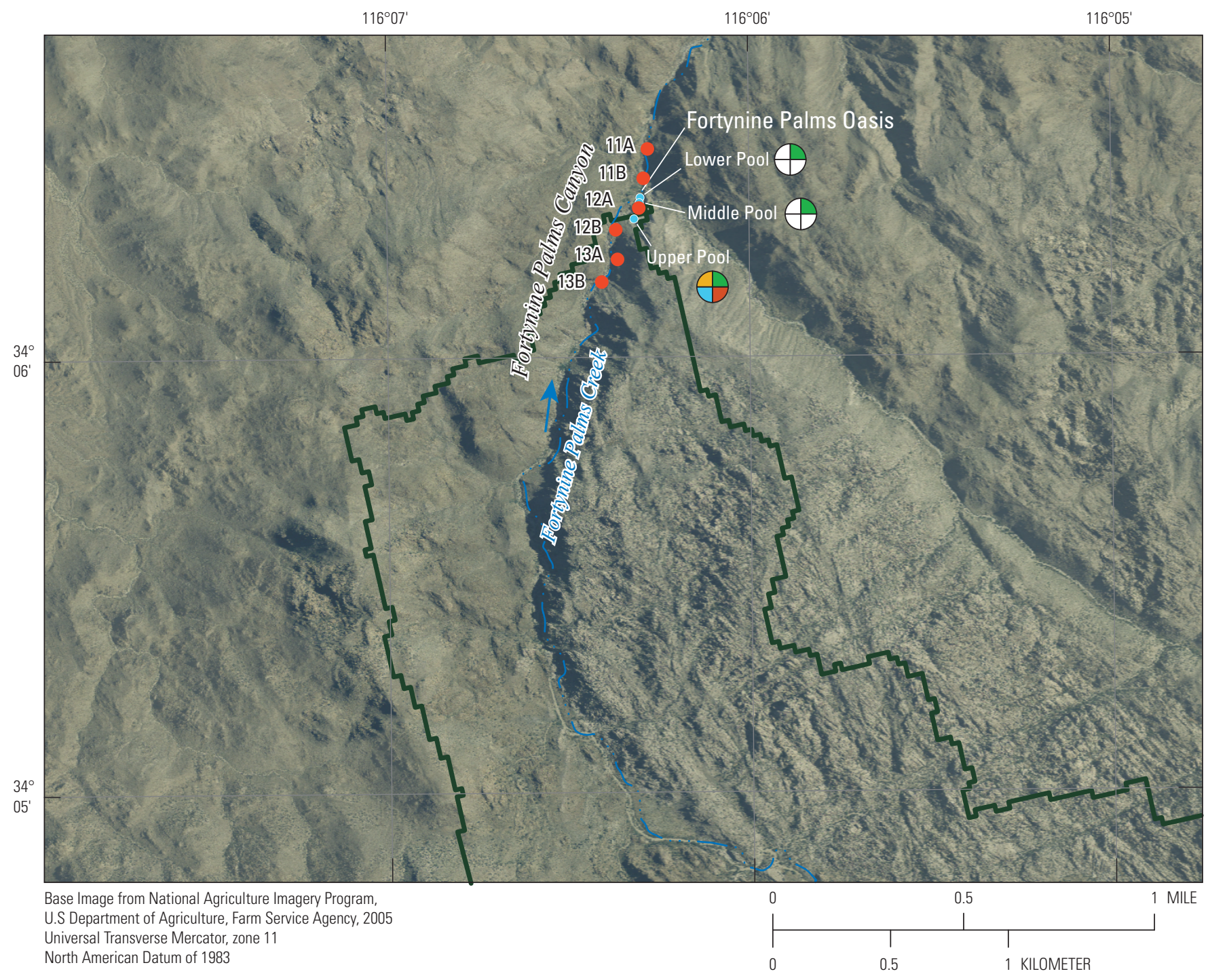

EXPLANATION

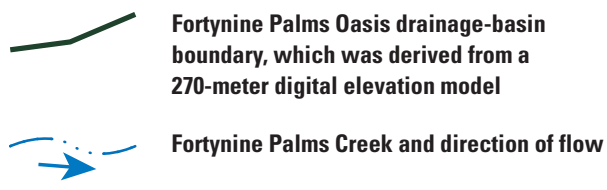
U.S. Geological Survey monitoring site- Filled part of circle shows type of sampling at each site

Air temperature

Water temperature

Water quality

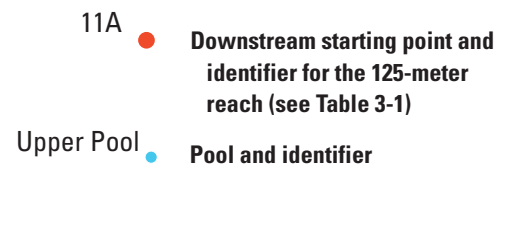

Figure 16. Survey reaches for hydrological and biological data collection at the Fortynine Palms Oasis study area, Mojave Network Parks, California, 2005-06. 


\section{California Treefrog (Pseudacris cadaverina)}

The California treefrog (Pseudacris cadaverina) is present from the California Coast Ranges in southern California to Baja California (fig. 1; Stebbins, 2003; Ervin and others, 2005). Fortynine Palms Oasis forms the easternmost extent of the California treefrog's range in California, but an unconfirmed account of this species in the Granite Mountains in the Mojave National Preserve could extend this boundary farther eastward (fig. 1; Greene and Luke, 1996; Ervin and others, 2005). Breeding typically takes place in still pools or in shallow flowing water upon bedrock surfaces (Storer, 1925; Miller and Stebbins, 1964; Ervin and others, 2005). Breeding at Fortynine Palms Oasis (fig. 1) begins as early as February and continues to October (Stebbins, 2003). The eggs are laid singly, but are surrounded by a gelatinous envelope that adheres to debris at the bottom of pools (Storer 1925; Stebbins, 1951; Gaudin, 1965). Tadpoles sustain themselves on detritus and algal matter until metamorphosis occurs in 40-75 days (Stebbins, 1951). Tadpoles generally are present in warmer, more shallow parts of the water column during the day and retreat to the deeper parts of the water column at night. Adulthood occurs in approximately 2 years when they become reproductively mature (Storer, 1925). The average life span of the California treefrog is unknown. Historically, the California treefrog occupied seven distinct drainages within the Joshua Tree National Park, but in 2006 was present in only three (Fortynine Palms Oasis, Rattlesnake Canyon, and Johnson Spring [fig. 12]). 
This page intentionally left blank. 


\section{Chapter B. Hydrological and Water- Quality Characterization of Selected Springs in the Mojave Network Parks}

\author{
By Roy A. Schroeder, Gregory A. Smith, Peter Martin, \\ and Alan L. Flint
}

Hydrological and water-quality investigations were done during 2005 and 2006 at the following three areas in the Mojave Network Parks: Darwin Falls in Death Valley National Park, Piute Spring in Mojave National Preserve, and Fortynine Palms Oasis in Joshua Tree National Park (table 1; fig. 1). Discharge, temperature, and water-quality data were collected and compared with available data to characterize the three study areas. Climatic variations also were used to help characterize the study areas.

\section{Methods}

The major hydrological, water-quality, and climate-modeling methods used for this study are briefly described in the following sections. Detailed descriptions of the methods are provided in documents referenced in the report.

\section{Hydrological Methods}

Water discharge and air and water temperature were measured at each of the study areas. The method of measurement varied depending on the location and quantity of discharge at each study area.

\section{Discharge}

Water discharge was measured at each of the three study areas while collecting the four scheduled water-quality samples at the end of the wet, spring season and at the end of the dry, summer season in 2005 and 2006 (table 2). However, only one measurement was made at Fortynine Palms Oasis (table 2; fig. 1) in 2005. Although discharge data are archived in cubic feet per second $\left(\mathrm{ft}^{3} / \mathrm{s}\right)$, which is the unit usually used to store this property in the U.S. Geological Survey (USGS) National Water Information System (NWIS), they also are presented in this report in gallons per minute (gal/min), which is a more intuitive unit when discharge is very low as it is at the study areas.
The permanent emplacement of artificial structures to obtain continuous discharge was prohibited by U.S. National Park Service (NPS) regulations; therefore, only instantaneous measurements of discharge were made when water-quality samples were collected. Three different methods were used to measure instantaneous discharge with the choice dictated by characteristics unique to each study area; the methods used were (1) calibrated portable Parshall flume, (2) calibrated portable V-notch weir plate, or (3) timed volumetric collection (Turnipseed and Saur, 2010). A Parshall flume was used to measure discharge in Darwin Wash below the pool at the base of Darwin Falls (fig. 6) and on Piute Creek (fig. 11) except for the first measurement on Piute Creek, which was done with a weir plate. All discharges from the Upper Pool at Fortynine Palms Oasis (fig. 16) were obtained by using the timed volumetric method. Use of a flume or a weir plate was not possible at this site because the minimal amount of soil available did not allow installation of a flume or a weir plate and because of braiding of the stream at the low discharge. Replicate measurements at each site yielded a relative standard deviation (coefficient of variation, which equals one-sigma $[1-\sigma]$ precision divided by the mean) that ranged from 1 to 8 percent, with best precision generally being associated with the timed volumetric method. However, reliability is poor at Piute Creek (fig. 11) because a variable part of the flow regularly emerges and disappears just beneath the gravel streambed.

Pressure transducers were temporarily deployed at each of the three study areas to record water depth (stage) in an attempt to obtain continuous proxy data for discharge during the 2 years of this study. It was recognized that the limited number (four site trips) of instantaneous discharge measurements planned for the study would likely preclude establishment of a good stage-discharge relation; however, the pressure-transducer data might still yield a useful record of flow response to precipitation events. A single pressure transducer was deployed at each of the three study areas. The pressure transducers used were multiparameter (they also recorded temperature) units from the following two suppliers: $\mathrm{HOBO}^{\circledR}$ U20 Water Level Loggers from Onset Computer Corporation or miniTROLL ${ }^{\circledR}$ Dataloggers from In-Situ Inc. ${ }^{\circledR}$. A pressure transducer was placed at each study area at the bottom of a natural pool thought most likely to persist throughout the 2-year study. Additional considerations were ability to camouflage for protection from human vandalism and wildlife disturbance, a reasonable expectation of instrument retrieval, and ease of instrument maintenance and data recovery (downloading). The pressure transducers were programmed to store data at 15-minute intervals. Unfortunately, as described in the following section, floods at each of the sites removed or destroyed the pressure transducers before data could be collected. Replacement pressure transducers were not installed at the sites after the floods. 


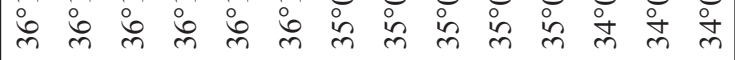


Table 2. Instantaneous discharge and general water-quality indicators determined in the field on samples collected in the Mojave Network Parks, California, 2005-06.

[See figures 6,11 , and 16 for site locations; hh, hours; mm, minutes; pxxxxx, five-digit parameter code used to uniquely identify each water constituent in the U.S. Geological Survey National Water Information System database; ${ }^{\circ} \mathrm{C}$, degrees Celsius; $\mathrm{mg} / \mathrm{L}$, milligrams per liter; $\mu \mathrm{S} / \mathrm{cm}$, microsiemens per centimeter; $\mathrm{CaCO}_{3}$, calcium carbonate; $\mathrm{ft}^{3} / \mathrm{s}$, cubic feet per second; gal/min, gallons per minute; RSD, relative standard deviation; - , no data; <, less than value shown]

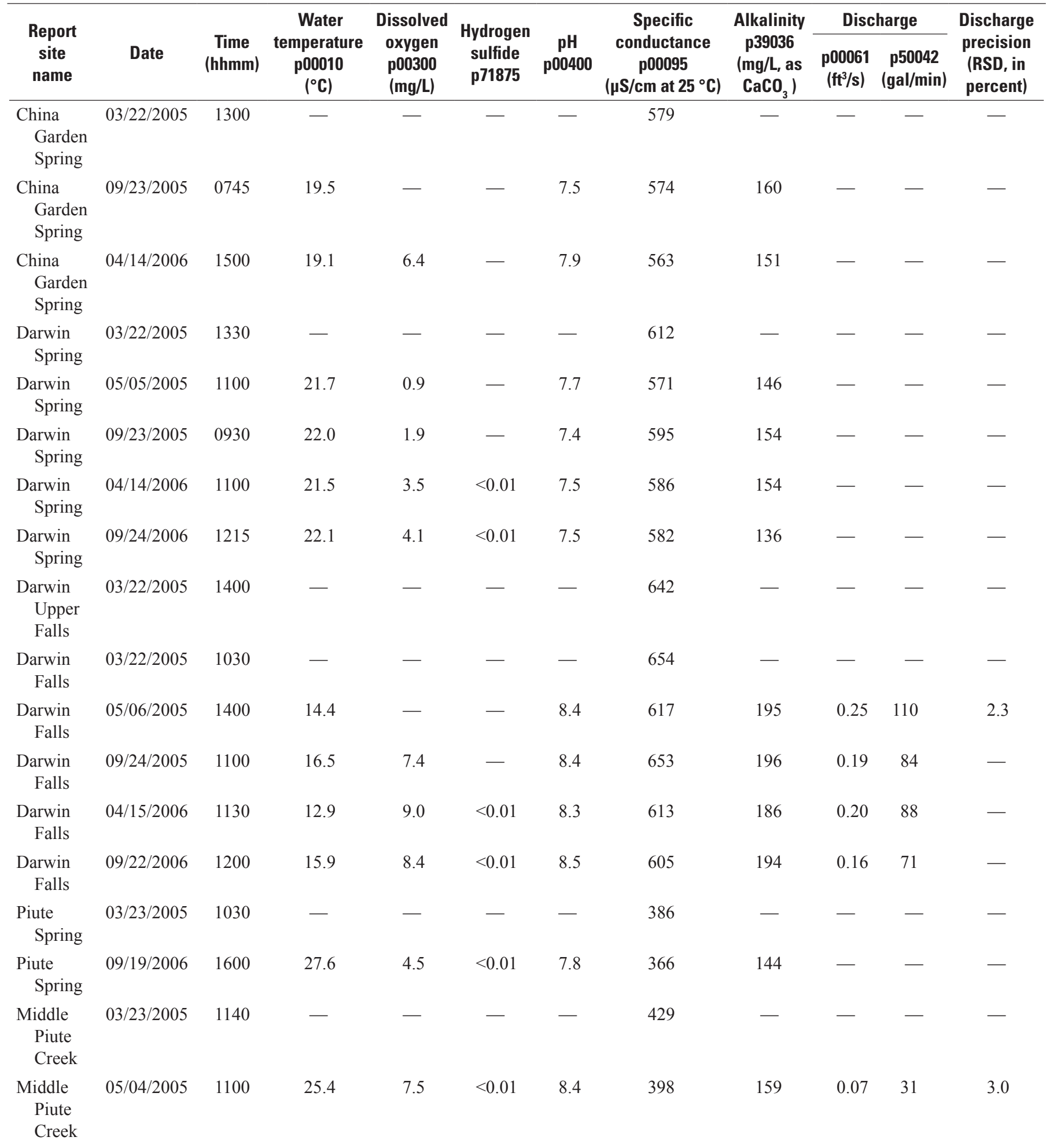


Table 2. Instantaneous discharge and general water-quality indicators determined in the field on samples collected in the Mojave Network Parks, California, 2005-06.-Continued

[See figures 6, 11, and 16 for site locations; hh, hours; mm, minutes; pxxxxx, five-digit parameter code used to uniquely identify each water constituent in the U.S. Geological Survey National Water Information System database; ${ }^{\circ} \mathrm{C}$, degrees Celsius; mg/L, milligrams per liter; $\mu \mathrm{S} / \mathrm{cm}$, microsiemens per centimeter; $\mathrm{CaCO}_{3}$, calcium carbonate; $\mathrm{ft}^{3} / \mathrm{s}$, cubic feet per second; gal/min, gallons per minute; RSD, relative standard deviation; - , no data; <, less than value shown]

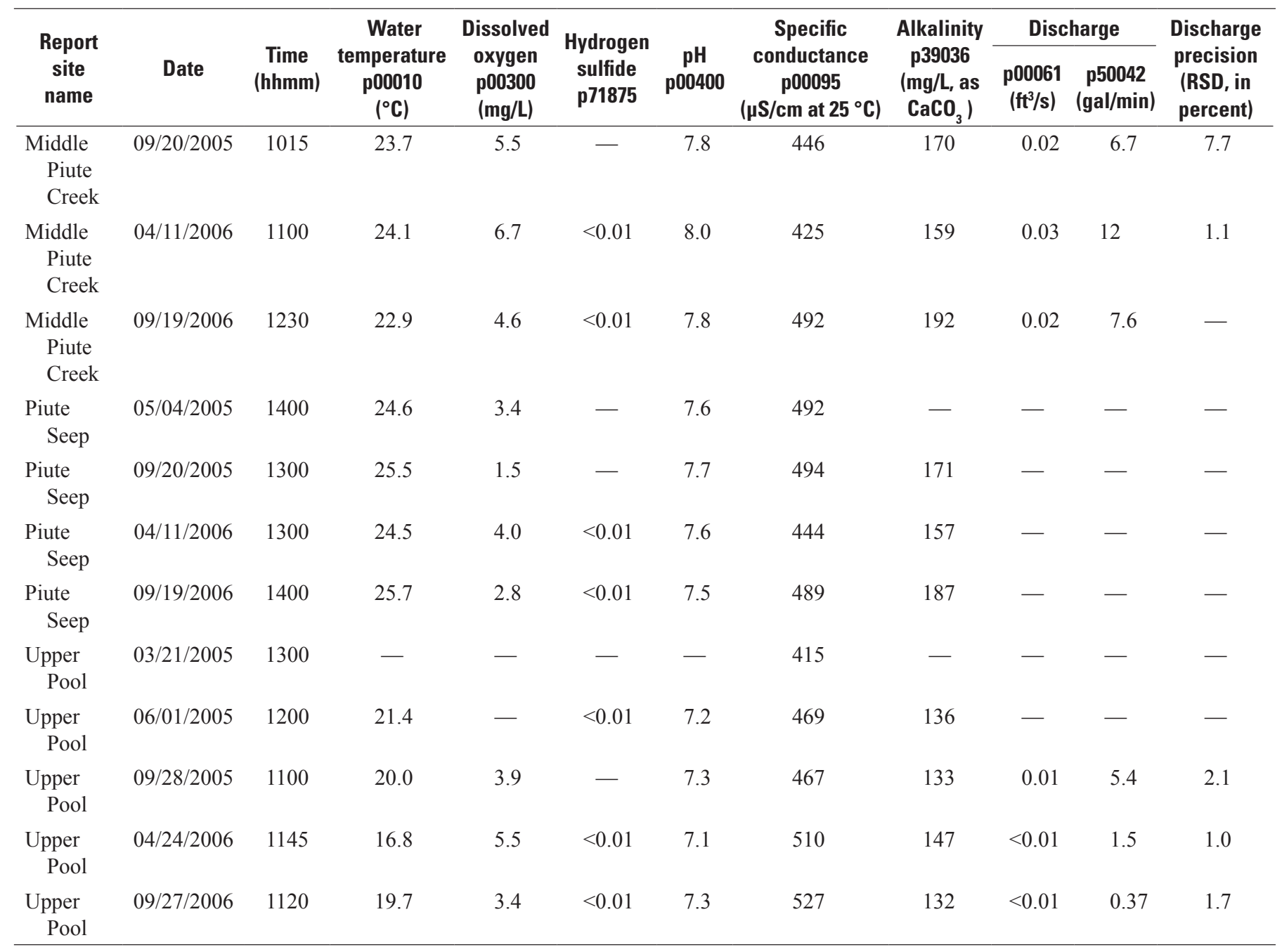


Flood events with sufficient intensity to alter the terrain and destroy pressure transducers and temperature probes occurred at all three of the study areas during the 2 years of this study. In the summer of 2005, a small flood at Darwin Falls (fig. 2) caused only small changes to the terrain and did not destroy any of the pressure transducers or temperature probes. In October 2005, a much larger flood caused substantial flattening and removal of vegetation in Darwin Wash just below Darwin Falls (fig. 2), as well as scouring and redeposition of sediment in the stream channel at several locations. A pressure transducer and several water-temperature probes were washed away and lost; however, the air-temperature probe and one water-temperature probe did survive this flood. In August 2005, a large flood at Piute Canyon (fig. 7) displaced large boulders, and scoured the soil and vegetation at this study's previously established sampling sites on Piute Creek (fig. 11) as well as farther down the canyon. Most of the deployed instruments including a large weir plate, a pressure transducer, and several water-temperature probes were washed away. An air-temperature probe, placed just above the floodplain, survived and was recovered. In July 2005, a large flood at Fortynine Palms Oasis (fig. 12) flattened vegetation, scoured and redeposited sediment and soils in and around the Upper Pool, and moved and repositioned rocks and boulders immediately downstream of the Upper Pool (fig. 16). An air-temperature probe/pressure transducer placed several feet above the Upper Pool (fig. 16) was saturated during the flood and recorded the event at about 1345 (military time) on July 24, 2005. The pressure transducer in the Upper Pool (fig. 16) was washed away during the flood and was not recovered.

\section{Temperature}

Water and air temperature were measured with a calibrated hand-held conventional glass-bulb thermometer, or with an electronic thermometer, at each of the three study areas while collecting the four scheduled water-quality samples. Continuous temperature data (recorded at 15-minute to 4-hour intervals, depending on the site) were obtained with probes installed at the point of water-quality sample collection and at various locations in the study area to cover the entire reach from which biological data were acquired. Dedicated, small temperature probes, about the size of a large coin, were deployed at each of the three study areas near the beginning of study area data collection to measure air and water temperature. The dedicated temperature probes used were StowAway $^{\circledR}$ TidbiTs $^{\circledR}$ supplied by Onset Computer Corporation. Two models, with the following temperature ranges, were deployed: one had a temperature range from -5 to 37 degrees Celsius $\left({ }^{\circ} \mathrm{C}\right)$ and an accuracy of plus or minus $0.2{ }^{\circ} \mathrm{C}$, and the other had a range from -20 to $50^{\circ} \mathrm{C}$ and an accuracy of plus or minus $0.4{ }^{\circ} \mathrm{C}$. The same considerations for instrument location used for the transducers were applied, with the additional provision that the temperature probes in air had to be in permanent shade. Temperature probes that were placed in water were fastened to the end of a 25 -centimeter $(\mathrm{cm})$ metal bracket that was inserted deep into the stream bank or streambed leaving the probe exposed at the water-soil interface. Where possible, anchor wires were attached from the bracket to nearby trees or snags; however, even this precaution proved inadequate to ensure instrument recovery after extreme flood events.

\section{Water-Quality Methods}

Water-quality samples were collected within each of the three study areas, and the sampling methods and types of analyses used were dependent on the individual site location within each study area (figs. 6, 11, and 16). The different sample-collection methods, field measurements, and laboratory analyses are described in the following sections.

\section{Sample Collection}

Sampling procedures followed protocols described in the USGS National Field Manual (U.S. Geological Survey, 2006a). Water samples were collected with a peristaltic pump and flexible C-flex tubing lowered to the bottom of pooled water, emplaced in the shallow streams (no more than a few centimeters deep), or lowered to the bottom of a 1-meter (m) stainless-steel well point driven into the ground at the spring orifice where installation was possible and permissible (table 1). A short stainless-steel tube was affixed to the inlet end of the flexible tubing as ballast to hold the intake in place just above the bottom of the pool or well point while water was being pumped to collection vessels. The type of collection vessel varied depending on the type of analysis planned for the sample. Water for immediate determination of specific conductance (EC), $\mathrm{pH}$, alkalinity, dissolved oxygen (DO or oxygen gas $\left.\left[\mathrm{O}_{2}\right]\right)$, and dissolved hydrogen sulfide $\left(\mathrm{H}_{2} \mathrm{~S}\right)$ in the field was obtained. This was followed by collection of samples for laboratory analysis of constituents that required no filtration. Air and water temperature were recorded in the field at the beginning of sample collection. Unfiltered samples for analysis of tritium $\left({ }^{3} \mathrm{H}\right)$ were collected in 1-liter (L) polyethylene bottles. Unfiltered samples for analysis of water (hydrogen $[\mathrm{H}]$ and oxygen [O]) isotopes were collected in small glass vials, sealed with a conical plastic screw cap, and taped with electrical tape to preclude leakage and evaporation before analysis.

After sufficient water for determination of field constituents and distribution of aliquots into appropriate containers was obtained as described above, a 0.45-micrometer $(\mu \mathrm{m})$ capsule filter (polyethersulfone membrane in a polypropylene housing) was attached to the outlet end of the flexible tubing; filtered samples were distributed into either polyethylene or amber glass bottles, depending on the constituent to be analyzed. Filtered water for analysis of anions and strontium (Sr) isotopes was collected in polyethylene bottles. Filtered water for analysis of major and minor cations and trace elements was collected in polyethylene bottles and stabilized by addition of a six-normal solution of nitric acid in the field to a $\mathrm{pH}$ of 2 . Dark brown polyethylene bottles were used for nutrients, and these samples were stored 
and shipped on ice to the laboratory, where they were refrigerated until analysis. Samples for analysis of pesticides from the Middle Piute Creek (fig. 11) at the Piute Spring study area and from the Upper Pool (fig. 16) at the Fortynine Palms Oasis study area (fig. 12) were obtained by submerging baked amber-glass bottles in the creek or pool, storing the samples on ice, and filtering them later in the laboratory through a $0.7-\mu \mathrm{m}$ glass-fiber filter before analysis.

Unfiltered water for analysis of common atmospheric gases was collected in a 150-milliliter $(\mathrm{mL})$ glass bottle in a bucket of water allowing the peristaltic pump to deliver sufficient water to displace accumulating sample water delivered by the peristaltic pump through the tube into the glass- collection bottle several times. The bottle was sealed, while still submerged in the bucket, with a rubber septum to which a syringe needle was attached to allow a small amount of sample water to vent as the septum was pushed into the neck of the bottle. Three replicates (successive samples) were collected, and they were stored and shipped on ice to the laboratory.

Unfiltered water for analysis of stable carbon isotopes and radiocarbon (carbon-14 $\left[{ }^{14} \mathrm{C}\right]$ ) was collected by bottom filling an amber glass bottle that was first purged with at least 3 bottle volumes of sample water to ensure displacement of all atmospheric carbon dioxide $\left(\mathrm{CO}_{2}\right)$ before sealing with a cap so that the sample had no head space.

Unfiltered water for analysis of noble gases was sampled last, and for collection the C-flex ${ }^{\circledR}$ tubing was replaced with Tygon ${ }^{\circledR}$ tubing because it is less pervious to gas exchange than $\mathrm{C}$-flex ${ }^{\circledR}$ or silicone tubing. An approximately 30 -cm length of $1.0 \mathrm{~cm}$ inside diameter copper tubing was inserted in the Tygon ${ }^{\circledR}$ tubing between the inlet and the peristaltic pump head so that water was pulled through the copper tubing as the pump was operating. The copper tube was held vertically in a manifold (a metal-plate holder with two clamps to hold the copper tube in place) and tapped vigorously to dislodge any gas bubbles that might have adhered to the copper tube or the Tygon ${ }^{\circledR}$ tubing. The pumping rate was then slowed as much as the pump's controller would permit to minimize cavitation or stripping of gases, and the outlet end of the copper tube was steadily crimped shut as the water was being pumped until flow was completely stopped; thereafter, the inlet end of the copper tube was completely crimped shut to trap the sample water with its associated dissolved noble gases (Weiss, 1968). The copper tubing containing the water sample was removed from the manifold and placed in bubble pack surrounded by urethane padding to minimize vibration during shipment to the laboratory.

\section{Field Measurements}

Data acquired while onsite in the field include the date and time sample collection began, water temperature, DO, dissolved $\mathrm{H}_{2} \mathrm{~S}, \mathrm{pH}$, specific conductance (EC), and alkalinity. The alkalinity reported was obtained in the field by incremental titration on filtered samples. Results from other methods of measuring alkalinity (unfiltered sample, titration to a fixed end point of $\mathrm{pH}=4.5$, and measurement in samples after they were received at the USGS National Water Quality Laboratory [NWQL]) are stored in NWIS, and are not presented in this report The slightly different methods yield nearly identical values. Values of EC and $\mathrm{pH}$ also were measured in samples after receipt by the NWQL, and these values also are available in NWIS. Values of EC measured later by the NWQL rarely differed by more than 3 percent from the value obtained in the field. However, many of the $\mathrm{pH}$ values measured later by the NWQL differ by more than plus or minus $0.1 \mathrm{pH}$ units from those made immediately in the field, because of biological activity and $\mathrm{CO}_{2}$ exchange in the intervening period of several days between field and lab measurements.

\section{Laboratory Analysis}

Major ions and minor elements analyzed for this report include calcium $(\mathrm{Ca})$, magnesium $(\mathrm{Mg})$, potassium $(\mathrm{K})$, sodium $(\mathrm{Na})$, bromide $(\mathrm{Br})$, chloride $(\mathrm{Cl})$, fluoride $(\mathrm{F})$, silica $\left(\mathrm{SiO}_{2}\right)$, sulfate $\left(\mathrm{SO}_{4}\right)$, and residue on evaporation (ROE) at 180 ${ }^{\circ} \mathrm{C}$, and are reported in milligrams per liter $(\mathrm{mg} / \mathrm{L})$ (table 3 ). Nutrients analyzed for this study include ammonia plus organic nitrogen (Kjeldahl-N), ammonia $\left(\mathrm{NH}_{4}\right)$, nitrite $\left(\mathrm{NO}_{2}\right)$ plus nitrate $\left(\mathrm{NO}_{3}\right), \mathrm{NO}_{2}$, and orthophosphate as phosphorus $\left(\mathrm{PO}_{4}-\mathrm{P}\right)$, and are reported in $\mathrm{mg} / \mathrm{L}$ (table 4). In this report, $\mathrm{NH}_{4}, \mathrm{NO}_{2}$, and $\mathrm{NO}_{3}$ are reported as nitrogen $(\mathrm{N})$, and referred to in this report as $\mathrm{NH}_{4}-\mathrm{N}, \mathrm{NO}_{2}-\mathrm{N}$, and $\mathrm{NO}_{3}-\mathrm{N}$. Trace elements analyzed for this study include arsenic (As), barium (Ba), boron (B), iron ( $\mathrm{Fe})$, lithium (Li), manganese (Mn), selenium $(\mathrm{Se})$, strontium $(\mathrm{Sr})$, vanadium $(\mathrm{V})$, and uranium $(\mathrm{U})$, and are reported in micrograms per liter $(\mu \mathrm{g} / \mathrm{L})$ (table 5 ).

Stable-isotope ratios were determined in this study for hydrogen (hydrogen- $1\left[{ }^{1} \mathrm{H}\right]$ and deuterium $\left[{ }^{2} \mathrm{H}\right.$ or $\left.\mathrm{D}\right]$ ), oxygen (oxygen-16 $\left[{ }^{16} \mathrm{O}\right]$ and oxygen-18 $\left[{ }^{18} \mathrm{O}\right]$ ), carbon (carbon-12 $\left[{ }^{12} \mathrm{C}\right]$ and carbon-13 $\left[{ }^{13} \mathrm{C}\right]$ ), and strontium (strontium-86 $\left[{ }^{86} \mathrm{Sr}\right]$ ) and strontium-87 [ $\left.{ }^{87} \mathrm{Sr}\right]$ ) (table 6). The isotopic composition for hydrogen $(\mathrm{H})$, oxygen $(\mathrm{O})$, and carbon $(\mathrm{C})$ are expressed in the standard delta ( $\delta \mathrm{iE})$ notation (Gonfiantini, 1978), in units of per mil (parts per thousand), as differences relative to a standard, by:

$$
\delta^{i} E=\left[\frac{\left(R_{\text {sample }}-R_{\text {sample }}\right)}{R_{\text {standard }}}\right] \times 10^{3}
$$

where

$$
\begin{aligned}
\mathrm{E} & \text { is the element being analyzed } \\
i & \begin{array}{l}
\text { is the number of neutrons of the heavier } \\
\text { isotope being analyzed }
\end{array} \\
R & \begin{array}{l}
\text { is the ratio of the heavier to the lighter } \\
\text { isotope for a given element. }
\end{array}
\end{aligned}
$$

The standard for $\mathrm{H}$ and $\mathrm{O}$ isotopes used in this study is Vienna Standard Mean Ocean Water (VSMOW); by convention, the VSMOW value for $\delta \mathrm{D}$ and $\delta^{18} \mathrm{O}$ is 0 per mil (Craig, 1961b). Analytical precision is plus or minus 1.5 per mil for $\delta \mathrm{D}$, and about plus or minus 0.5 per mil for $\delta^{18} \mathrm{O}$ (Coplen, 1994; Izbicki, 1996). The standard for C isotopes 


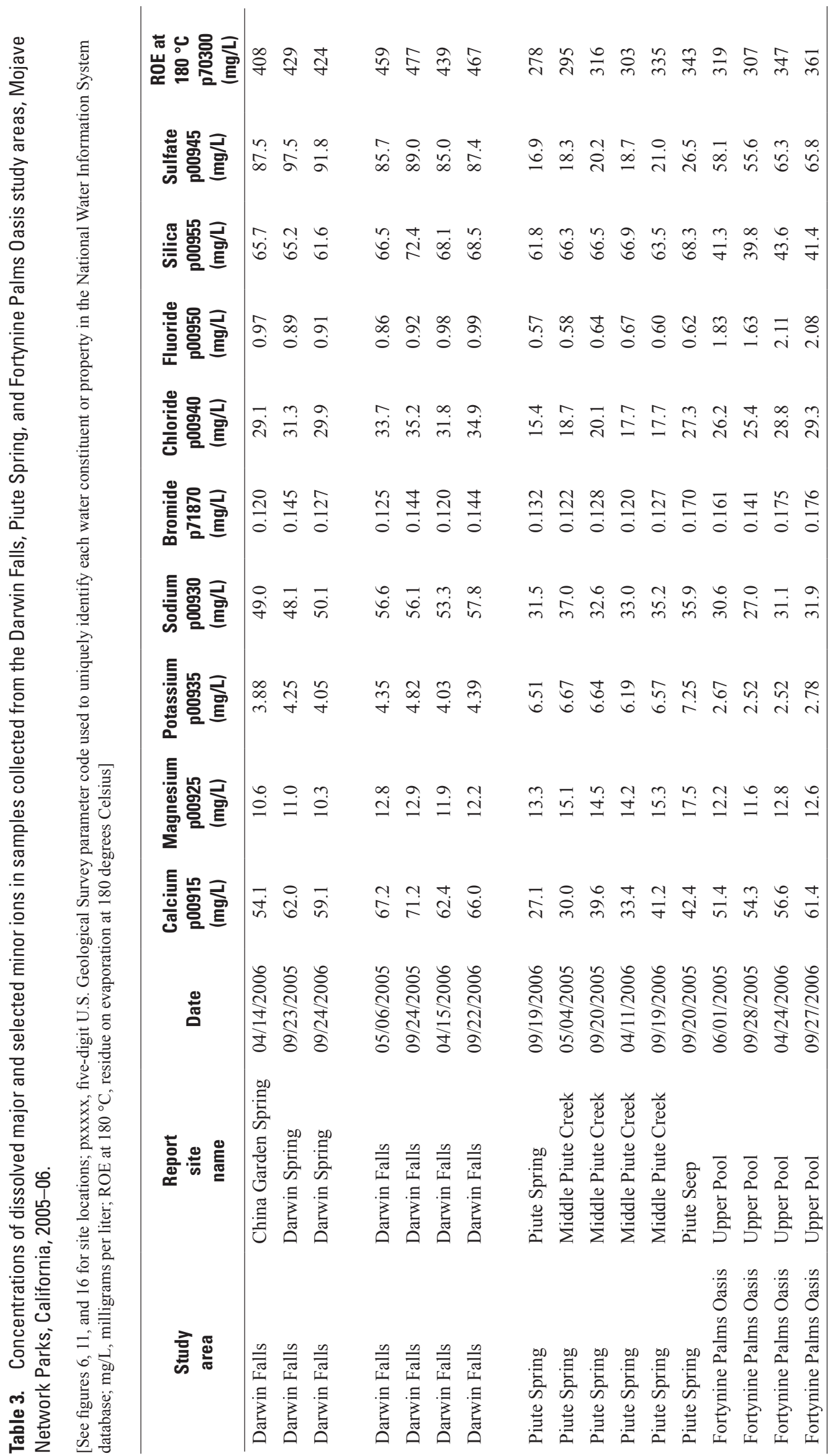




\section{Source, Discharge, and Chemical Characteristics of Selected Springs and Endemic Anuran Species, Mojave Network Parks}

Table 4. Concentrations of dissolved nutrients in samples collected from the Darwin Falls, Piute Spring, and Fortynine Palms Oasis study areas, Mojave Network Parks, California, 2005-06.

[See figures 6, 11, and 16 for site locations; pxxxxx, five-digit U.S. Geological Survey parameter code used to uniquely identify each water constituent or property in the National Water Information System database; mg/L, milligrams per liter; N, nitrogen; P, phosphorous; <, less than value shown; E, value estimated]

\begin{tabular}{lcccccr}
\hline $\begin{array}{c}\text { Report } \\
\text { site } \\
\text { name }\end{array}$ & Date & $\begin{array}{c}\text { Ammonia }+ \\
\text { organic nitrogen } \\
\text { p00623 } \\
\text { (mg/L, as N) }\end{array}$ & $\begin{array}{c}\text { Ammonia } \\
\text { p00608 } \\
\text { (mg/L, as N) }\end{array}$ & $\begin{array}{c}\text { Nitrite + nitrate } \\
\text { p00631 } \\
\text { (mg/L, as N) }\end{array}$ & $\begin{array}{c}\text { Nitrite } \\
\text { p00613 } \\
\text { (mg/L, as N) }\end{array}$ & $\begin{array}{c}\text { Orthophosphate } \\
\text { p00671 } \\
\text { (mg/L, as P) }\end{array}$ \\
\hline China Garden Spring & $04 / 14 / 2006$ & $<0.10$ & $<0.04$ & 0.68 & $<0.008$ & $<0.020$ \\
Darwin Spring & $09 / 23 / 2005$ & 0.42 & $<0.04$ & 0.06 & $\mathrm{E} 0.006$ & $<0.020$ \\
Darwin Spring & $09 / 24 / 2006$ & $\mathrm{E} 0.09$ & $<0.01$ & 0.86 & $<0.002$ & 0.031 \\
Darwin Falls & $05 / 06 / 2005$ & $<0.10$ & $<0.04$ & 0.12 & $<0.008$ & $\mathrm{E} 0.010$ \\
Darwin Falls & $09 / 24 / 2005$ & $\mathrm{E} 0.08$ & $<0.04$ & 0.23 & $<0.008$ & 0.020 \\
Darwin Falls & $04 / 15 / 2006$ & $\mathrm{E} 0.05$ & $<0.04$ & 0.07 & $<0.008$ & $\mathrm{E} 0.010$ \\
Darwin Falls & $09 / 22 / 2006$ & 0.10 & $<0.01$ & $<0.06$ & $<0.002$ & 0.027 \\
Piute Spring & $09 / 19 / 2006$ & $\mathrm{E} 0.06$ & $<0.01$ & 3.01 & $<0.002$ & 0.021 \\
Middle Piute Creek & $05 / 04 / 2005$ & $\mathrm{E} 0.05$ & $<0.04$ & 2.17 & $<0.008$ & $<0.020$ \\
Middle Piute Creek & $09 / 20 / 2005$ & 0.12 & $<0.04$ & 2.94 & $<0.008$ & $\mathrm{E} 0.020$ \\
Middle Piute Creek & $04 / 11 / 2006$ & 0.28 & $<0.04$ & 2.62 & $<0.008$ & $<0.020$ \\
Middle Piute Creek & $09 / 19 / 2006$ & 0.12 & $<0.01$ & 2.23 & 0.008 & 0.026 \\
Piute Seep & $09 / 20 / 2005$ & 0.25 & $<0.04$ & 2.93 & 0.012 & $\mathrm{E} 0.02$ \\
Upper Pool & $06 / 01 / 2005$ & $\mathrm{E} 0.06$ & $<0.04$ & 0.12 & $<0.008$ & $<0.020$ \\
Upper Pool & $09 / 28 / 2005$ & 0.17 & $<0.04$ & 0.10 & $<0.008$ & $<0.020$ \\
Upper Pool & $04 / 24 / 2006$ & 0.49 & $<0.04$ & 0.08 & $<0.008$ & $<0.020$ \\
Upper Pool & $09 / 27 / 2006$ & 0.15 & $\mathrm{E} 0.009$ & $\mathrm{E} 0.03$ & $<0.002$ & 0.012 \\
\hline
\end{tabular}




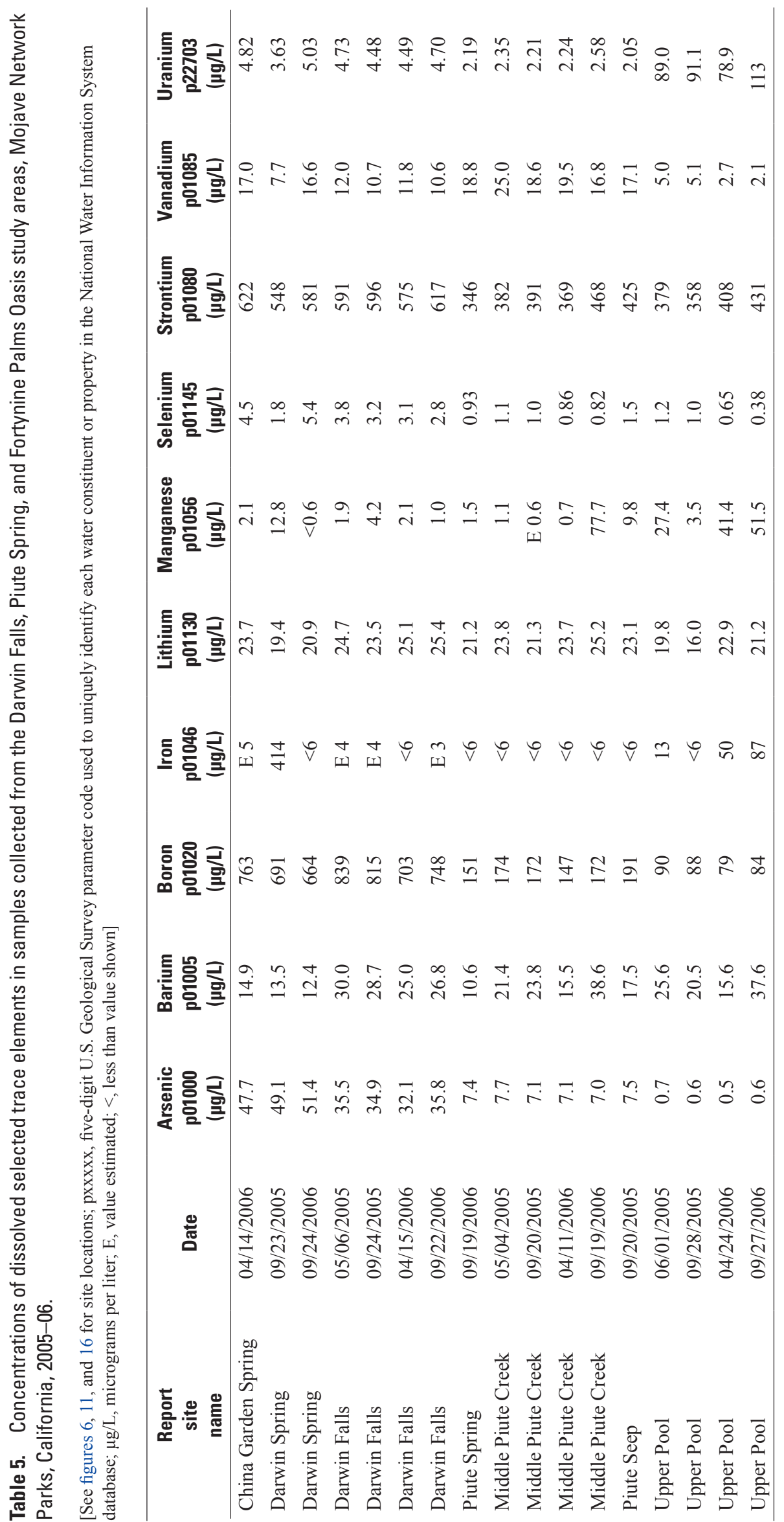




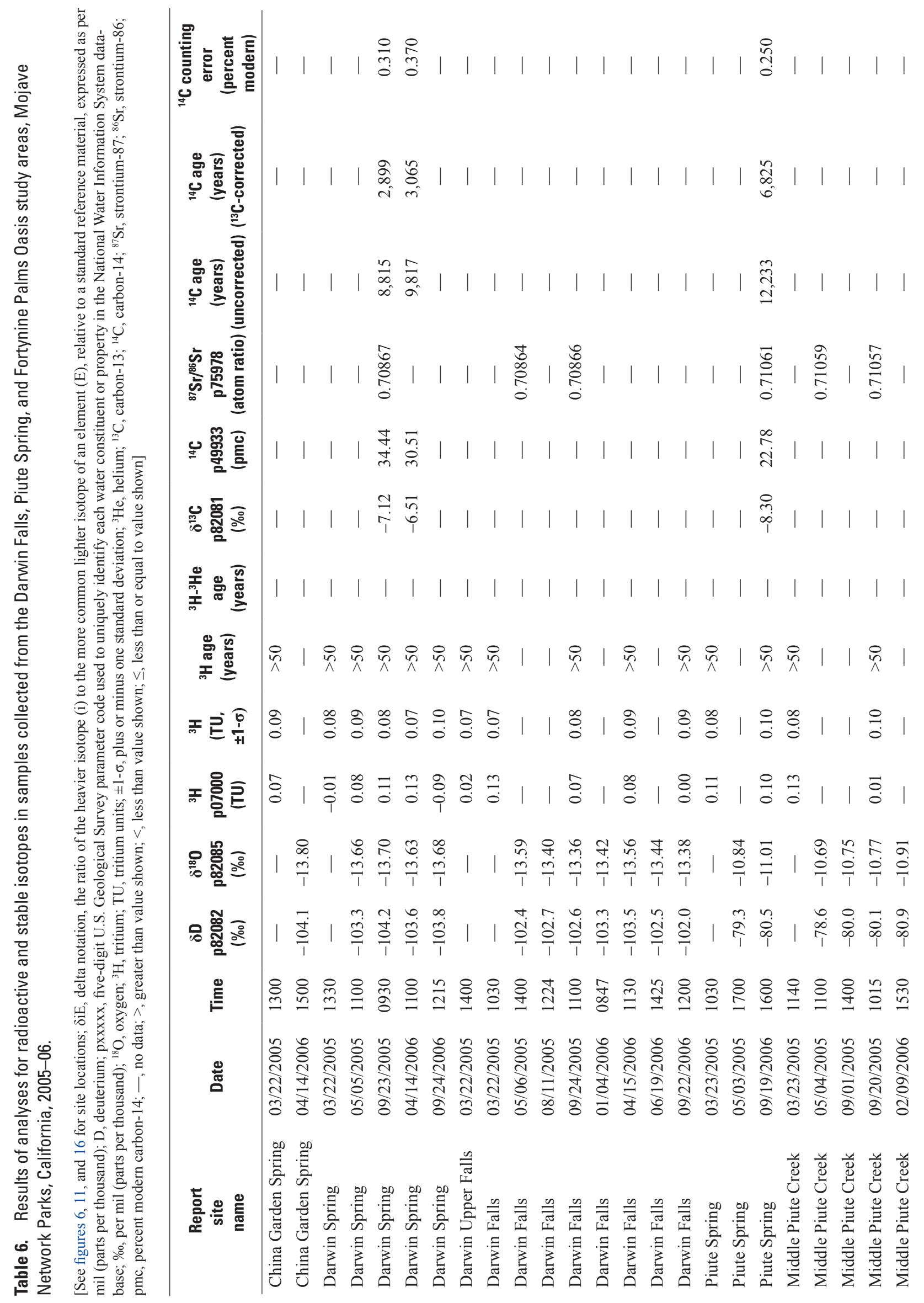




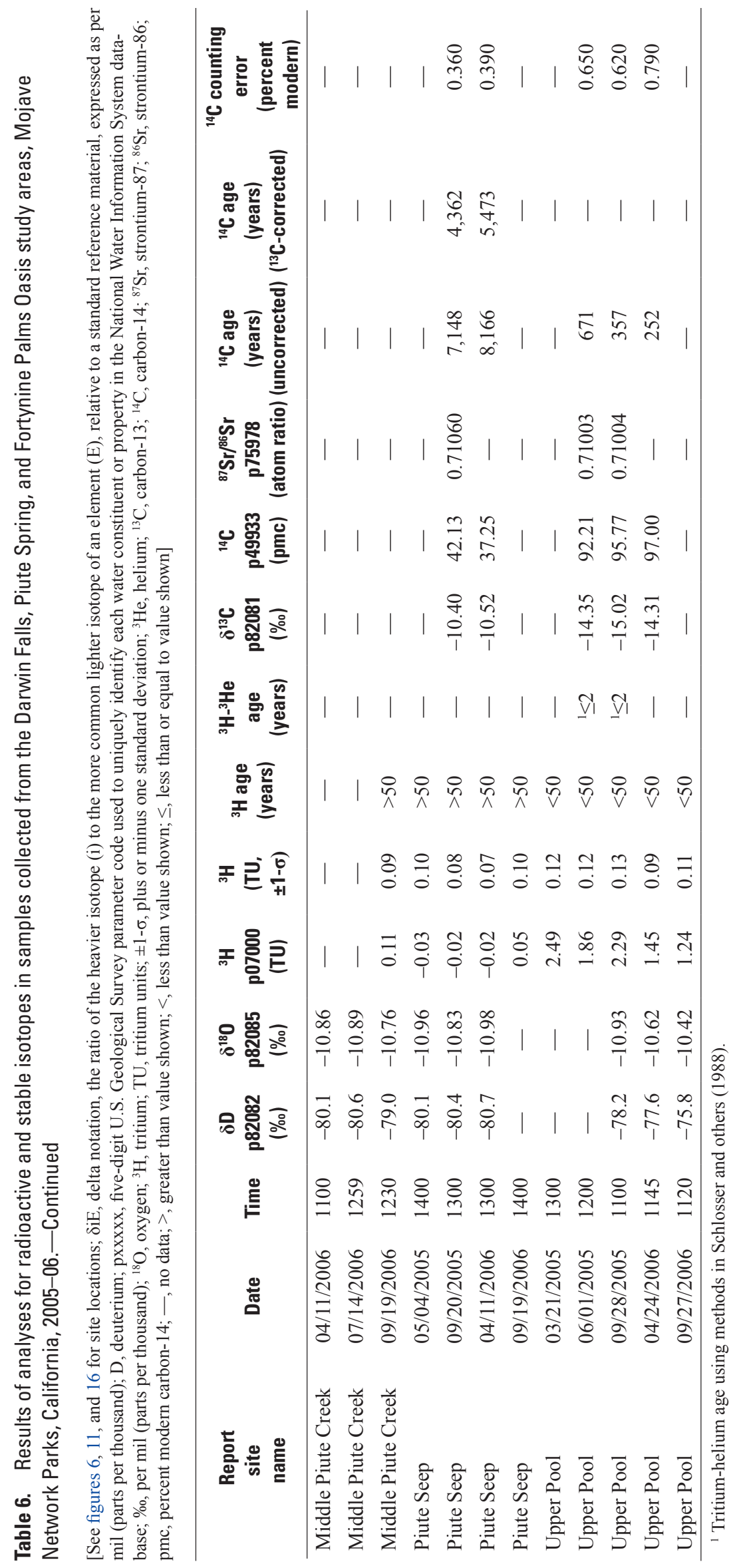


is Vienna Pee Dee Belemnite (VPDB; Friedman and O'Neil, 1977; Coplen, 1994). Analytical precision is about plus or minus 0.5 per mil for $\delta^{13} \mathrm{C}$. Strontium isotopes are measured and reported directly as atom ratios $\left({ }^{87} \mathrm{Sr} /{ }^{86} \mathrm{Sr}\right)$ to 4 or 5 significant digits (table 6).

The radioactive isotope of $\mathrm{H}$ (helium-3 or tritium $\left[{ }^{3} \mathrm{H}\right]$ ) was analyzed for this study and reported in tritium units (TU), and the plus or minus $1-\sigma$ precision of the ${ }^{3} \mathrm{H}$ analysis also was reported in TU (table 6). The radioactive isotope of $\mathrm{C}$ $\left(\mathrm{C}-14\left[{ }^{14} \mathrm{C}\right]\right)$ is reported as percent modern carbon $(\mathrm{pmc})$ by comparing ${ }^{14} \mathrm{C}$ activities to the specific activity of National Bureau of Standards oxalic acid; 12.88 disintegrations per minute per gram (g) of $\mathrm{C}$ in the year 1950 equals $100 \mathrm{pmc}$ (Mazor, 1991) (table 6).

Concentrations of dissolved gases in water samples for the following five gases commonly present in the atmosphere were analyzed for this study and are reported in $\mathrm{mg} / \mathrm{L}$ : methane $\left(\mathrm{CH}_{4}\right), \mathrm{CO}_{2}$, nitrogen gas $\left(\mathrm{N}_{2}\right), \mathrm{O}_{2}$, and argon (Ar) (table 7). Concentrations of the dissolved noble (inert) gases helium (He), neon ( $\mathrm{Ne})$, argon ( $\mathrm{Ar}$ ), krypton ( $\mathrm{Kr}$ ), and xenon (Xe) were measured for this study, and are reported in cubic centimeters per gram of water at standard temperature and pressure $\left(\mathrm{cm}^{3} \mathrm{STP} / \mathrm{g} \mathrm{H}_{2} \mathrm{O}\right.$ ) (table 8).

Selected pesticide concentrations were analyzed in a sample collected from Fortynine Palms Oasis (fig. 16) on April 24, 2006, and in a sample collected from Piute Creek (fig. 11) on May 17, 2006 (table 9). Both polar and moderately polar suites of pesticides were analyzed at Fortynine Palms Oasis (fig. 12), but only the polar compounds were analyzed at Piute Creek (fig. 11).

Several laboratories analyzed water samples collected for this study for chemicals and isotopes. Major ions, minor and trace elements, and nutrients were analyzed by the USGS NWQL (Timme, 1995) by various methods as described in Fishman and Friedman (1989), Patton and Truitt (1992 and 2000), Faires (1993), Fishman (1993), McLain (1993), Struzeski and others (1996), Garbarino (1999), Patton and Kryskalla (2003), and Garbarino and others (2006). Pesticides were analyzed by the NWQL using solid-phase (graphitized-carbon) extraction and high-pressure liquid or gas chromatography-mass spectrometry (Furlong and others, 2001; Sandstrom and others, 2001; Madsen and others, 2003). Activity of ${ }^{3} \mathrm{H}$ was measured by the USGS National Research Program (NRP) Tritium-Light Isotope laboratory in Menlo Park, Calif., by electrolytic enrichment using glass cells with electrodes of nickel and stainless steel (Ostlund and Werner, 1962). The electrolyzed samples were then counted in liquid scintillation counters as 1:1 mixtures of water and a commercial scintillator (Thatcher and others, 1977). Lawrence Livermore National Laboratory (LLNL) analyzed helium-3 $(3 \mathrm{He})$ and other noble gases by accelerator-mass spectrometry (Eaton and others, 2004). Dissolved common atmospheric gases were analyzed by the NRP Chlorofluorocarbon Laboratory in Reston, Va., by gas chromatography. Stable isotopes of water $\left({ }^{1} \mathrm{H}, \mathrm{D},{ }^{16} \mathrm{O},{ }^{18} \mathrm{O}\right)$ were analyzed by the NRP Stable-Isotope laboratory in Reston, Va. (Epstein and Mayeda, 1953; Coplen and others, 1991; Coplen, 1994). Isotopes of $\mathrm{Sr}$ were analyzed by the NRP Heavy-Isotope laboratory in Menlo
Park, Calif. (Bullen and others, 1996). Stable C isotopes $\left({ }^{12} \mathrm{C}\right.$ and ${ }^{13} \mathrm{C}$ ) and ${ }^{14} \mathrm{C}$ were analyzed at the University of Waterloo by methods described in Donahue and others (1990), and Jull and others (2004).

\section{Climate Modeling}

The distributed-parameter water-balance model known as the Basin Characterization Model (BCM) has been applied in previous studies (Flint and Flint, 2007a and 2007b) to evaluate regional climatic factors and physical properties that produce runoff and groundwater recharge in the southwestern United States. The BCM uses a deterministic mathematical approach that accounts for the temporal and spatial distribution of precipitation (including the accumulation and melting of snow) along with the spatial distribution of soils, vegetation, and hydraulic conductivity of underlying materials to estimate the amount of water available as in-place recharge or runoff on a monthly basis (Flint and others, 2004). Precipitation and temperature for the southwestern United States were estimated for the BCM by using spatially distributed estimates of monthly and yearly precipitation, and temperature data provided by Parameter Regression on Independent Slopes Model (PRISM; Daly and others, 2004; http://prism.oregonstate.edu/) at grid spacing of about 4 kilometers $(\mathrm{km})$ for the long-term climatic record (1895-2006). The PRISM grids were refined and resampled to a finer resolution of $270 \mathrm{~m}$ by using a model developed by Nalder and Wein (1998), which combines a spatial gradient and inverse distance squared weighting to monthly and yearly point data with multiple regressions. A search radius of 10,000 $\mathrm{m}$ was used to limit the effect of distant data. Approximately 25 PRISM grid cells are used to estimate the model parameters for precipitation for each 270-m cell with the closest cell having the most effect. Precipitation was extrapolated to the long-term (1895-2006) climatic record based on a regression between measured and estimated data. This time variant gridded dataset is referred to here as modified PRISM.

Precipitation, temperature, and potential in-place recharge and runoff estimated for 1970-2006 were extracted from the regional BCM developed by Flint and Flint (2007a) for the drainage basins upstream from Darwin Spring, Piute Spring, and Fortynine Palms Oasis (figs. 2, 7, and 12, respectively). Long-term recharge (1895-2006) was estimated for these drainage basins by relating annual recharge to annual precipitation using a threshold-limited power function for each drainage basin (Flint and Flint, 2007a). The actual percentage of runoff that becomes recharge is unknown in these drainage basins but could be determined in subsequent studies and analyses. Flint and others (2004), in their study of potential recharge in Nevada, determined that the percentage of $\mathrm{BCM}$ simulated runoff that becomes recharge ranged from about 10 percent in southern Nevada to about 80 percent in some locations in northern Nevada. Flint and Martin (2012), in their study of recharge in Big Bear Valley in San Bernardino County, Calif. (fig. 1), assumed that 10 percent of the BCM simulated runoff becomes recharge, and the combined value 


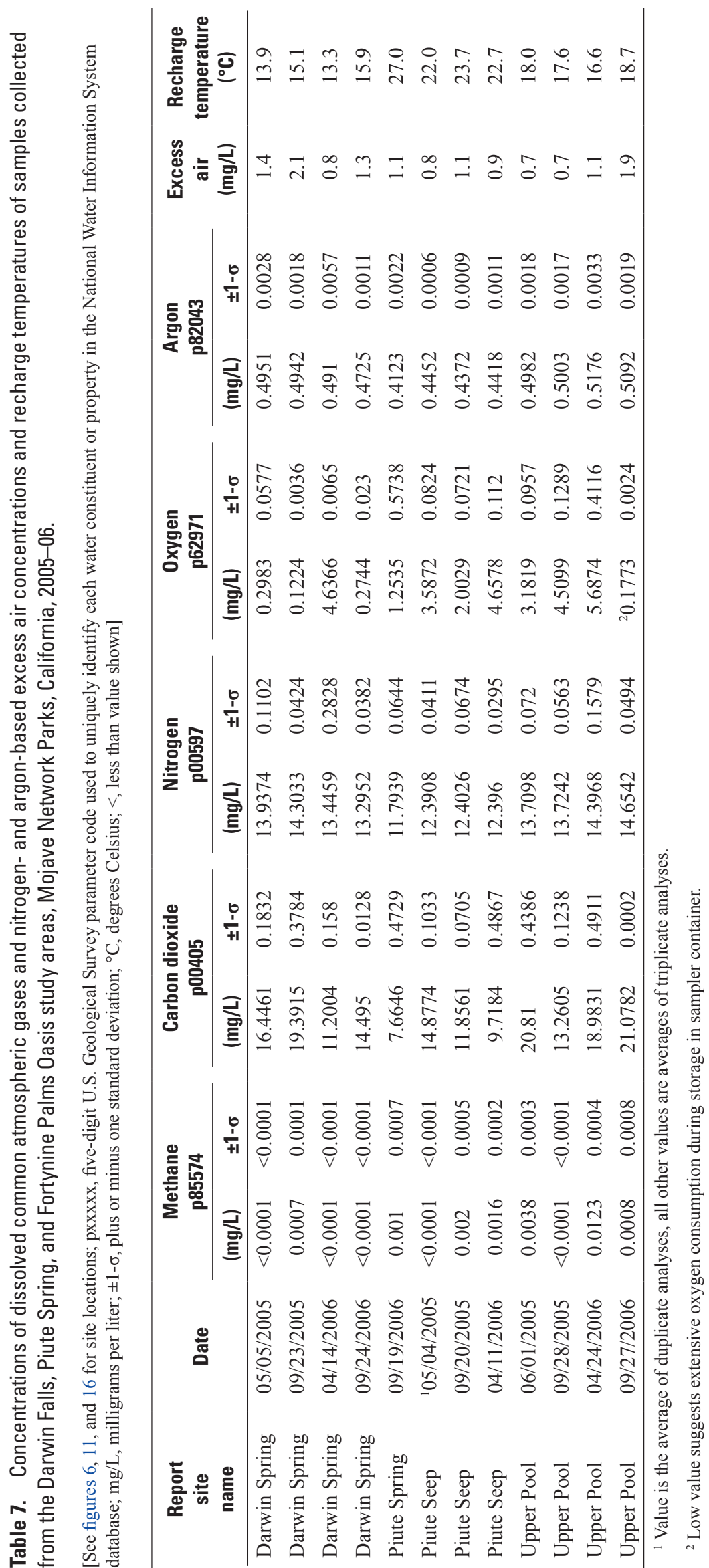




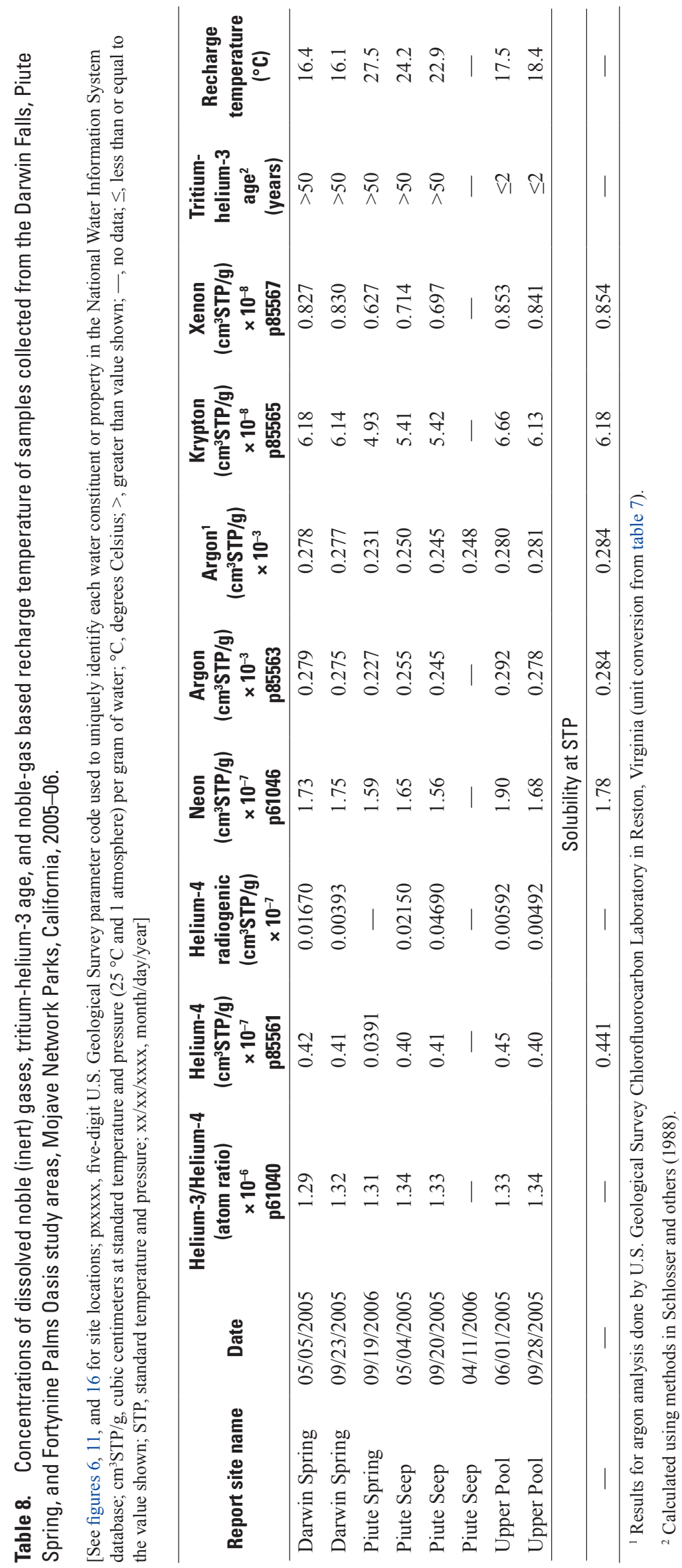


Table 9. Concentrations of dissolved pesticides in samples collected from the Darwin Falls, Piute Spring, and Fortynine Palms Oasis study areas, Mojave Network Parks, California, 2005-06.

[See figures 6, 11, and 16 for site locations; constituents in bold are surrogate compounds that were added to the samples; $\mu \mathrm{g} / \mathrm{L}$, micrograms per liter; - , not analyzed; <, less than value shown; E, estimated concentration less than value indicated; xx/xx/xxxx, month/day/year]

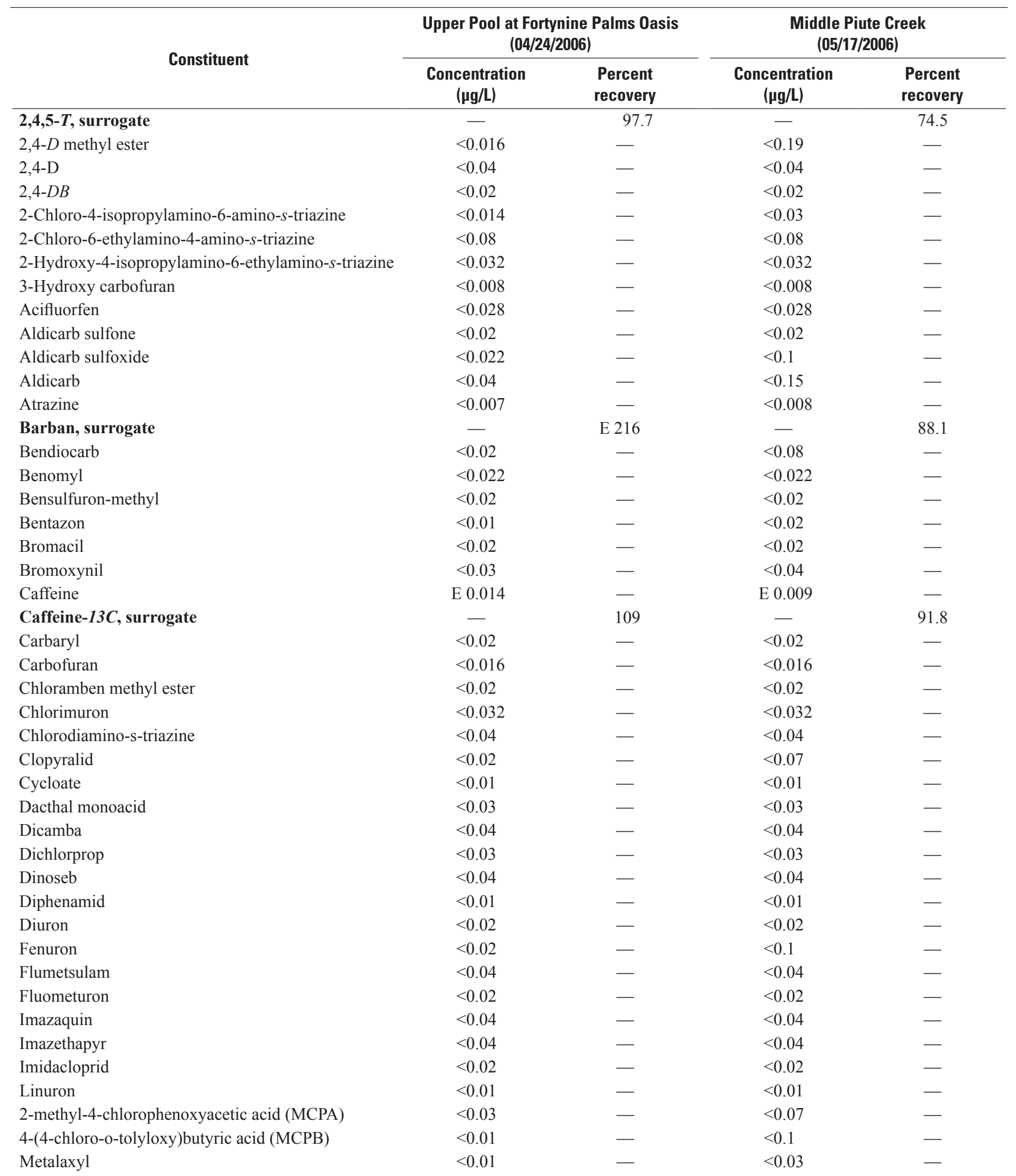


Table 9. Concentrations of dissolved pesticides in samples collected from the Darwin Falls, Piute Spring, and Fortynine Palms Oasis study areas, Mojave Network Parks, California, 2005-06.-Continued

[See figures 6,11 , and 16 for site locations; constituents in bold are surrogate compounds that were added to the samples; $\mu \mathrm{g} / \mathrm{L}$, micrograms per liter; - , not analyzed; <, less than value shown; E, estimated concentration less than value indicated; xx/xx/xxxx, month/day/year]

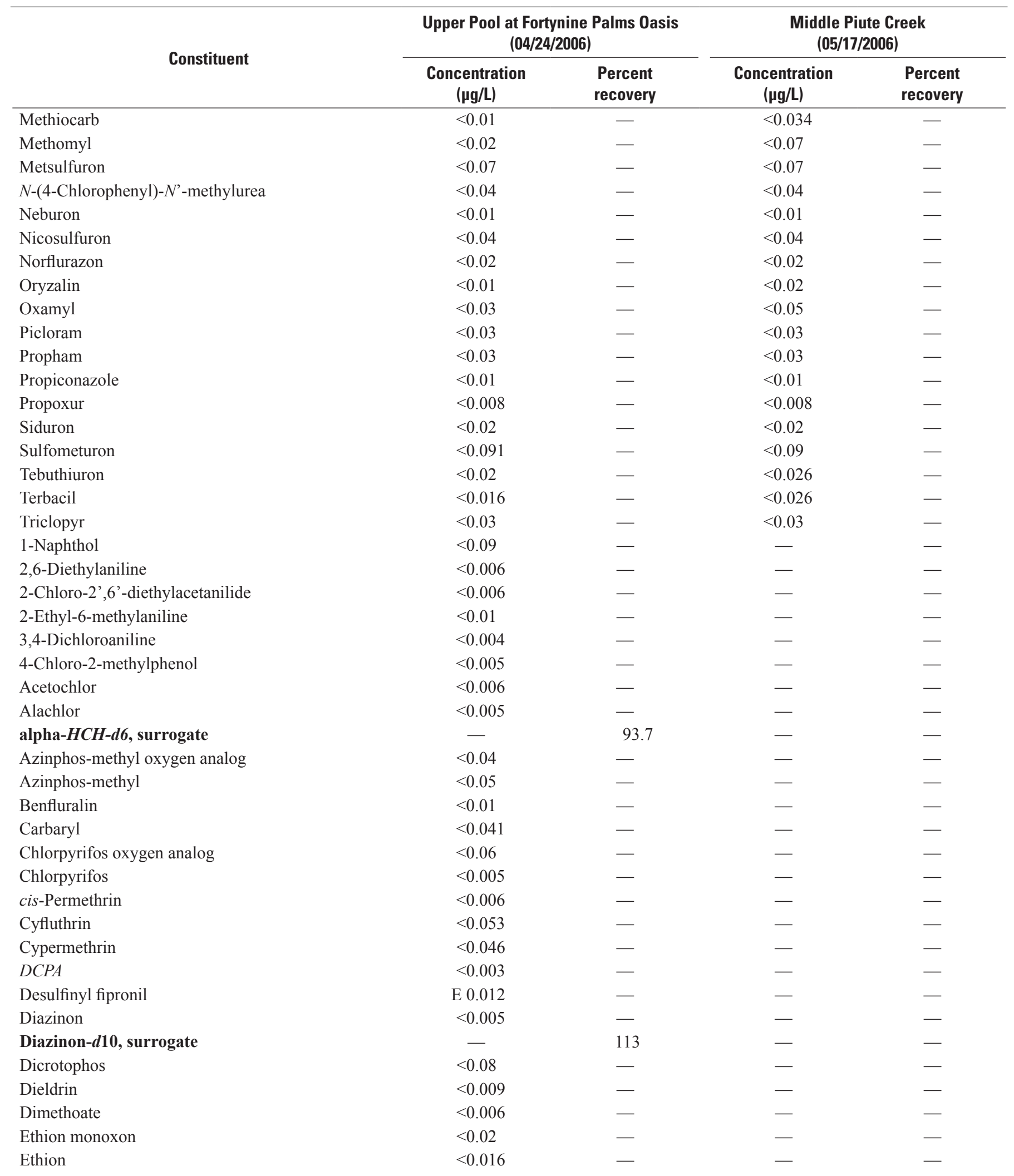


Table 9. Concentrations of dissolved pesticides in samples collected from the Darwin Falls, Piute Spring, and Fortynine Palms Oasis study areas, Mojave Network Parks, California, 2005-06.-Continued

[See figures 6, 11, and 16 for site locations; constituents in bold are surrogate compounds that were added to the samples; $\mu \mathrm{g} / \mathrm{L}$, micrograms per liter; - , not analyzed; <, less than value shown; E, estimated concentration less than value indicated; xx/xx/xxxx, month/day/year]

\begin{tabular}{|c|c|c|c|c|}
\hline \multirow{2}{*}{ Constituent } & \multicolumn{2}{|c|}{$\begin{array}{l}\text { Upper Pool at Fortynine Palms Oasis } \\
(04 / 24 / 2006)\end{array}$} & \multicolumn{2}{|c|}{$\begin{array}{l}\text { Middle Piute Creek } \\
\quad(05 / 17 / 2006)\end{array}$} \\
\hline & $\begin{array}{c}\text { Concentration } \\
(\mu \mathrm{g} / \mathrm{L})\end{array}$ & $\begin{array}{l}\text { Percent } \\
\text { recovery }\end{array}$ & $\begin{array}{l}\text { Concentration } \\
(\mu \mathrm{g} / \mathrm{L})\end{array}$ & $\begin{array}{l}\text { Percent } \\
\text { recovery }\end{array}$ \\
\hline Fenamiphos sulfone & $<0.053$ & - & - & - \\
\hline Fenamiphos sulfoxide & $<0.04$ & - & - & - \\
\hline Fenamiphos & $<0.03$ & - & - & - \\
\hline Desulfinylfipronil amide & $<0.029$ & - & - & - \\
\hline Fipronil sulfide & E 0.006 & - & - & - \\
\hline Fipronil sulfone & Е 0.007 & - & - & - \\
\hline Fipronil & E 0.011 & - & - & - \\
\hline Fonofos & $<0.005$ & - & - & - \\
\hline Hexazinone & $<0.026$ & - & - & - \\
\hline Iprodione & $<0.026$ & - & - & - \\
\hline Isofenphos & $<0.011$ & - & - & - \\
\hline Malaoxon & $<0.039$ & - & - & - \\
\hline Malathion & $<0.027$ & - & - & - \\
\hline Metalaxyl & $<0.007$ & - & - & - \\
\hline Methidathion & $<0.009$ & - & - & - \\
\hline Methyl paraoxon & $<0.02$ & - & - & - \\
\hline Methyl parathion & $<0.015$ & - & - & - \\
\hline Metolachlor & $<0.006$ & - & - & - \\
\hline Metribuzin & $<0.028$ & - & - & - \\
\hline Myclobutanil & $<0.033$ & - & - & - \\
\hline Pendimethalin & $<0.022$ & - & - & - \\
\hline Phorate oxygen analog & $<0.03$ & - & - & - \\
\hline Phorate & $<0.055$ & - & - & - \\
\hline Prometon & $<0.01$ & - & - & - \\
\hline Prometryn & $<0.006$ & - & - & - \\
\hline Propyzamide & $<0.004$ & - & - & - \\
\hline Simazine & $<0.005$ & - & - & - \\
\hline Terbufos oxygen analog sulfone & $<0.04$ & - & - & - \\
\hline Terbufos & $<0.02$ & - & - & - \\
\hline Terbuthylazine & $<0.01$ & - & - & - \\
\hline Trifluralin & $<0.009$ & - & - & - \\
\hline Dichlorvos & $<0.01$ & - & - & - \\
\hline
\end{tabular}


of simulated in-place and runoff recharge was within the range of the total recharge estimated by using a daily rainfallrunoff model. Based on these previous studies, the total BCM recharge for each drainage basin in the current study was assumed to be equal to the simulated potential in-place recharge plus 10 percent of the simulated runoff.

\section{Hydrological Results and Discussion}

Discharge, temperature, general water-quality indicators such as salinity, temperature of recharge, and age of the water were used to help evaluate the source, discharge, and chemical characteristics of springs in the Darwin Falls, Piute Spring, and Fortynine Palms Oasis drainage basins (figs. 2, 7, and 12 , respectively). Where available, historical hydrological and water-quality data also were used. Hydrological and water-quality data obtained for this study are stored in NWIS, and can be accessed by the public at http://waterdata.usgs.gov/ nwis/ by using the 8- or 15-digit USGS station identification (ID) numbers on table 1 . The hydrological and water-quality data compiled and analyzed for this study are discussed in the following sections for each of the three drainage basins (tables 2-9). A "Site Comparisons" section, which compares results between the different spring drainage basins, follows this discussion.

\section{Darwin Falls, Death Valley National Park}

Six USGS monitoring sites were established in the Darwin Falls study area in the Death Valley National Park to evaluate the hydrogeology and water quality of the riparian habitat of the Darwin Falls area: China Garden Spring, Darwin Spring, Darwin Upper Falls, Darwin Falls, Darwin Wash gaging station, and Darwin Wash downstream (fig. 6). The sites were monitored for discharge, air temperature, water temperature, and (or) water quality depending on the conditions and location of the site (table 1; fig. 6).

\section{Discharge}

Although Darwin Spring is the initial observed source of spring discharge above Darwin Falls (fig. 2), its discharge is minimal when compared to total stream discharge at Darwin Falls itself. The presence of dense vegetation between Darwin Spring and Darwin Upper Falls (fig. 6), and the emergence of flow in Darwin Canyon downstream of Darwin Spring indicates that Darwin Wash is gaining flow downstream of Darwin Spring from additional springs and seeps (fig. 6). Four discharge measurements made at the Darwin Falls monitoring site, approximately $23 \mathrm{~m}$ downstream from Darwin Falls (fig. 6), ranged from $0.25 \mathrm{ft}^{3} / \mathrm{s}(110 \mathrm{gal} / \mathrm{min})$ in May 2005 to $0.16 \mathrm{ft}^{3} / \mathrm{s}$ (71 gal $/ \mathrm{min}$ ) in September 2006 (table 2). The modified PRISM simulated annual precipitation also decreased from 2005 to 2006 (fig. 17), indicating a correlation between discharge and precipitation during the 2-year study (fig. 18A). Precipitation and discharge would need to be collected on a monthly basis for at least 5 years to determine if there is a relation between precipitation and discharge (Schertz and others, 1991).

Discharge in Darwin Wash (fig. 6) was monitored continuously for 27 years between October 1962 and September 1989 at USGS gaging station 10250800 (Darwin Wash near Darwin, Calif.). The gaging station is $155 \mathrm{~m}$ downstream from Darwin Falls (fig. 6; gaging station relocated 58 meters upstream from previous location on August 6, 1970). Base flow from January 1, 1963, through December 31, 1988, was estimated from streamflow-hydrograph separation by using a streamflow partitioning program (PART; Rutledge, 1993) on daily values of streamflow recorded at the outlet of the Darwin Falls drainage basin (fig. 2). Base flow is that part of streamflow usually attributed to groundwater discharge (U.S. Geological Survey, 1989) which, in the Darwin Falls drainage basin (fig. 2), is primarily groundwater discharge in Darwin Canyon downgradient of Darwin Spring (fig. 6). The PART computer program estimated that the mean annual streamflow at the Darwin Wash gaging station during $1963-88$ was $0.41 \mathrm{ft}^{3} / \mathrm{s}(184 \mathrm{gal} / \mathrm{min})$, and the mean annual base flow was $0.25 \mathrm{ft}^{3} / \mathrm{s}(112 \mathrm{gal} / \mathrm{min})$ —about 61 percent of the gaged streamflow (table 10). The mean winter base flow was $0.29 \mathrm{ft}^{3} / \mathrm{s}(130 \mathrm{gal} / \mathrm{min})$, and the mean summer base flow was $0.21 \mathrm{ft}^{3} / \mathrm{s}(94 \mathrm{gal} / \mathrm{min})$, indicating that base flow responds to greater precipitation in the winter months (table 10). In general, base flow is lower in years of low precipitation and higher in years of high precipitation (fig. 19). A quick rise in stream height can temporarily reverse the normal hydraulic gradient along a gaining stream channel, and cause water to flow back into the aquifer and become bank storage (Brater, 1940). A large part of base flow may be supplied by the release of bank storage after a flow event (Kunkle, 1965, 1968). The higher calculated base flow in winter months and years of high precipitation in Darwin Wash (fig. 2) is, in part, the result of the release of bank storage upstream of the gaging station.

Three discharge measurements reported by Reaburn and Bowen (1928) for Darwin Wash between 1917 and 1928 ranged from 0.30 to $0.38 \mathrm{ft}^{3} / \mathrm{s}$, which is more than 20 percent greater than discharge measured during this study (table 11). It is not possible to examine causes for the difference in discharge measurements because information on the location of the older measurements, the method used to obtain them, and number of days elapsed since each previous precipitation event were not available.

The continuous discharge record at Darwin Wash (fig. 2) between October 1962 and September 1989 (fig. 19) indicated that large flood events recurred every few years. The highest discharge during the 27 years that the Darwin Wash gaging station was operated took place on January 25, 1969, when instantaneous discharge reached $4,400 \mathrm{ft}^{3} / \mathrm{s}$ and mean-daily discharge was $432 \mathrm{ft}^{3} / \mathrm{s}$. Floodmarks indicate that water reached about $2.6 \mathrm{~m}$ above the gage height datum at the gaging station (Hoffman and others, 1990; p. 37), which is much higher than the flood event that occurred during October 2005 of this study that altered terrain and destroyed 

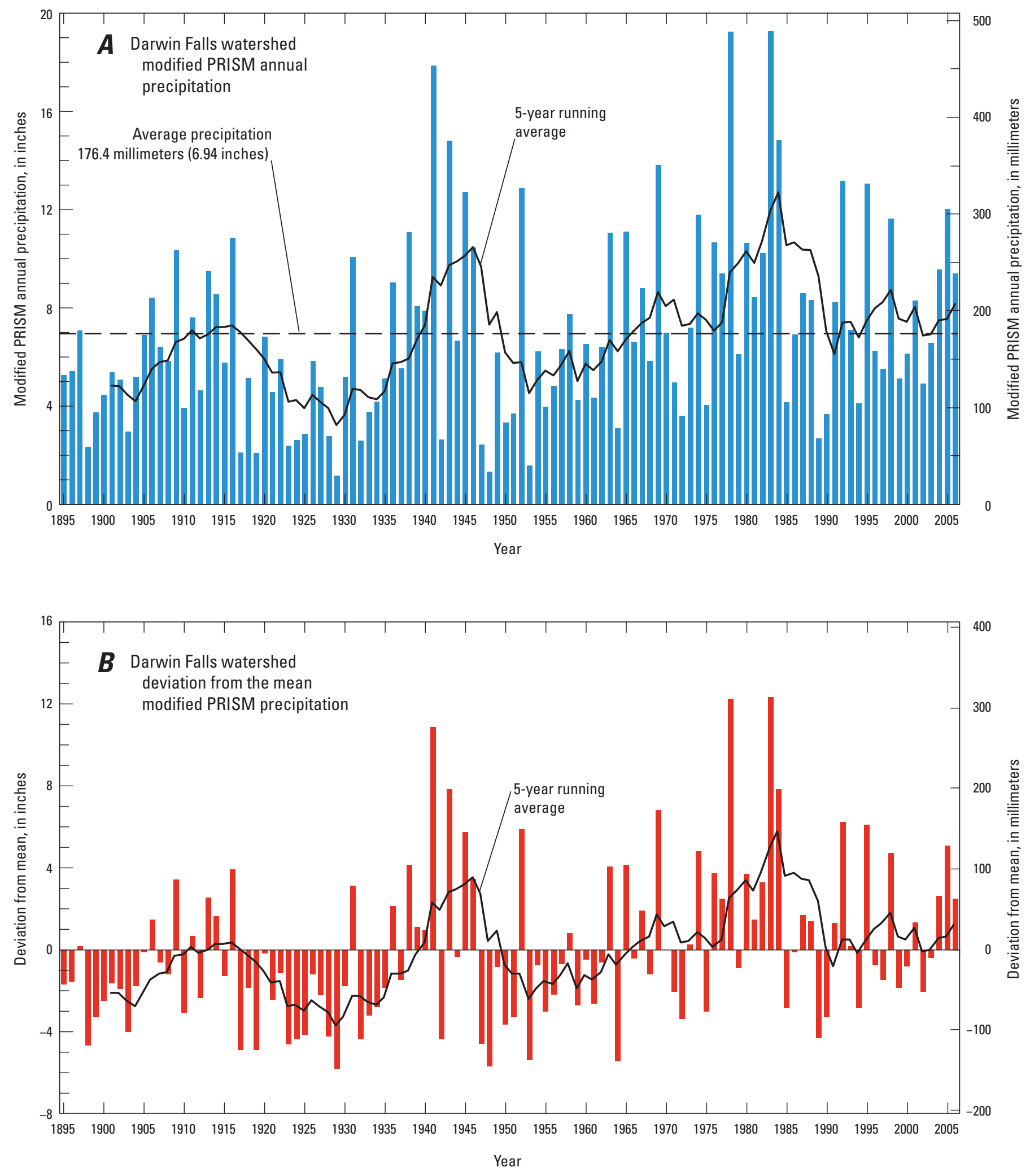

Figure 17. Modified Parameter Regression on Independent Slopes Model (PRISM) annual precipitation and deviation from the mean for the Darwin Falls drainage basin, Mojave Network Parks, California, 1895-2006. $A$, Annual precipitation. $B$, Deviation from the mean. 

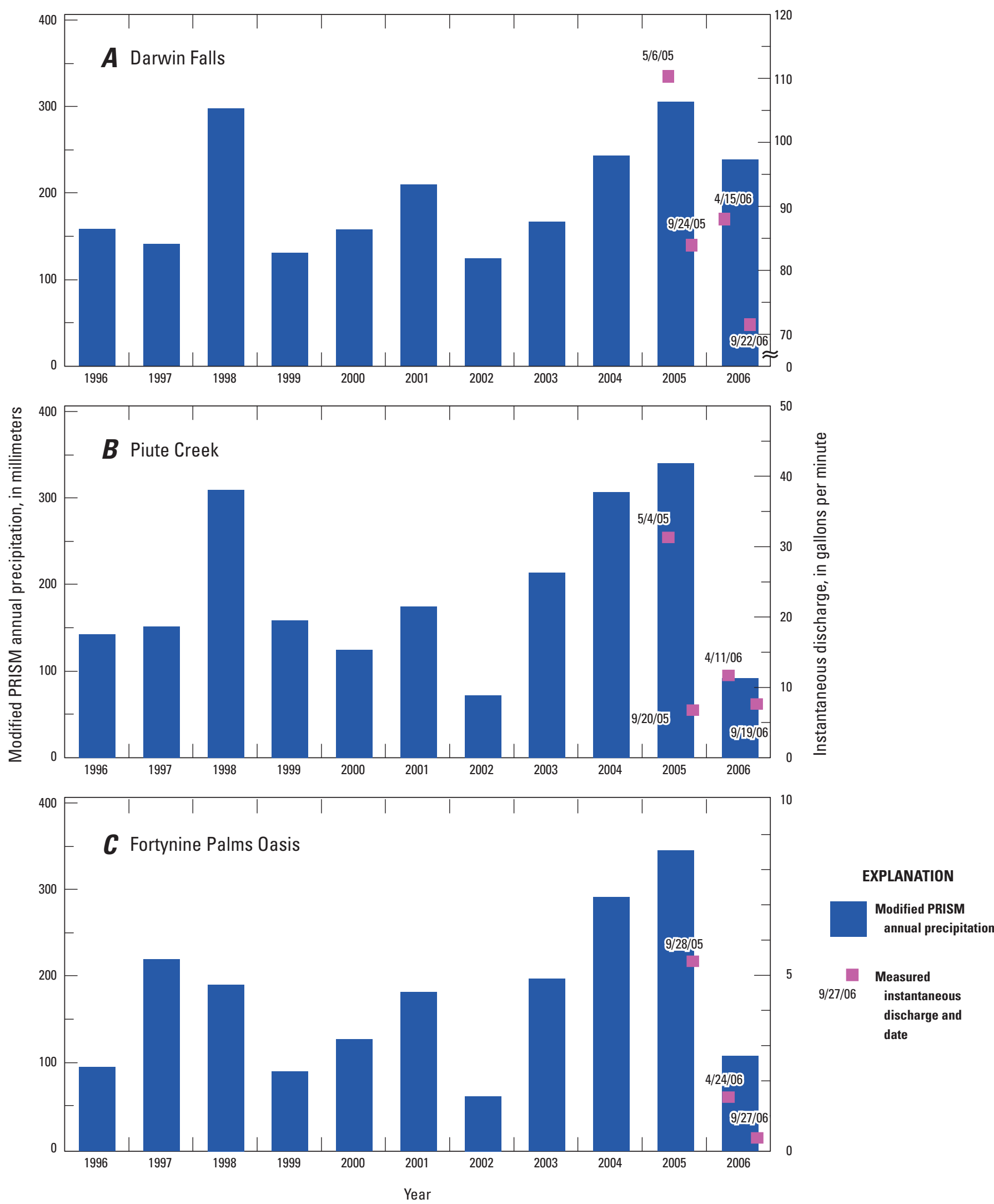

Figure 18. Comparison of the modified Parameter Regression on Independent Slopes Model (PRISM) annual precipitation and instantaneous discharge measurements in the Mojave Network Parks, California, 2005-06. A, Darwin Falls. B, Piute Creek. C, Fortynine Palms 0asis. 
Table 10. Annual and seasonal streamflow and base flow at the Darwin Wash gaging station (10250800) calculated using the PART program, Mojave Network Parks, California, 1963-88.

[Winter, January 1-March 3; spring, April 1-June 30; summer, July 1-September 30; fall, October 1-December 31]

\begin{tabular}{|c|c|c|c|c|c|c|c|c|c|c|c|}
\hline Year & Winter & Spring & Summer & Fall & Annual & Year & Winter & Spring & Summer & Fall & Annual \\
\hline \multicolumn{6}{|c|}{ Streamflow, in cubic feet per second } & \multicolumn{6}{|c|}{ Base flow, in cubic feet per second } \\
\hline 1963 & 0.34 & 0.28 & 0.23 & 0.32 & 0.29 & 1963 & 0.34 & 0.28 & 0.22 & 0.31 & 0.29 \\
\hline 1965 & 0.33 & 0.31 & 0.47 & 0.53 & 0.41 & 1965 & 0.33 & 0.31 & 0.37 & 0.36 & 0.34 \\
\hline 1966 & 0.33 & 0.50 & 0.42 & 0.71 & 0.49 & 1966 & 0.33 & 0.46 & 0.39 & 0.35 & 0.38 \\
\hline 1968 & 0.26 & 0.20 & 0.99 & 0.30 & 0.44 & 1968 & 0.26 & 0.19 & 0.22 & 0.30 & 0.24 \\
\hline 1969 & 7.16 & 0.27 & 0.21 & 0.21 & 1.96 & 1969 & 0.52 & 0.27 & 0.21 & 0.21 & 0.30 \\
\hline 1970 & 0.23 & 0.18 & 0.15 & 0.21 & 0.19 & 1970 & 0.23 & 0.18 & 0.14 & 0.20 & 0.19 \\
\hline 1971 & 0.19 & 0.16 & 0.09 & 0.15 & 0.15 & 1971 & 0.18 & 0.14 & 0.09 & 0.14 & 0.14 \\
\hline 1972 & 0.18 & 0.26 & 0.14 & 0.23 & 0.20 & 1972 & 0.18 & 0.15 & 0.14 & 0.23 & 0.17 \\
\hline 1976 & 0.22 & 0.31 & 0.30 & 0.35 & 0.29 & 1976 & 0.21 & 0.23 & 0.26 & 0.34 & 0.26 \\
\hline 1977 & 0.28 & 0.24 & 0.16 & 0.39 & 0.27 & 1977 & 0.28 & 0.22 & 0.15 & 0.38 & 0.26 \\
\hline 1978 & 0.98 & 0.33 & 0.28 & 0.30 & 0.47 & 1978 & 0.21 & 0.30 & 0.19 & 0.28 & 0.25 \\
\hline 1979 & 0.23 & 0.21 & 0.11 & 0.17 & 0.18 & 1979 & 0.18 & 0.15 & 0.08 & 0.16 & 0.14 \\
\hline 1980 & 0.22 & 0.16 & 0.10 & 0.20 & 0.17 & 1980 & 0.20 & 0.15 & 0.10 & 0.19 & 0.16 \\
\hline 1981 & 0.38 & 0.23 & 0.28 & 0.26 & 0.29 & 1981 & 0.38 & 0.21 & 0.17 & 0.26 & 0.25 \\
\hline 1982 & 0.30 & 0.19 & 0.24 & 0.27 & 0.25 & 1982 & 0.30 & 0.19 & 0.23 & 0.25 & 0.24 \\
\hline 1983 & 0.48 & 0.19 & 2.04 & 0.54 & 0.81 & 1983 & 0.27 & 0.17 & 0.27 & 0.51 & 0.30 \\
\hline
\end{tabular}



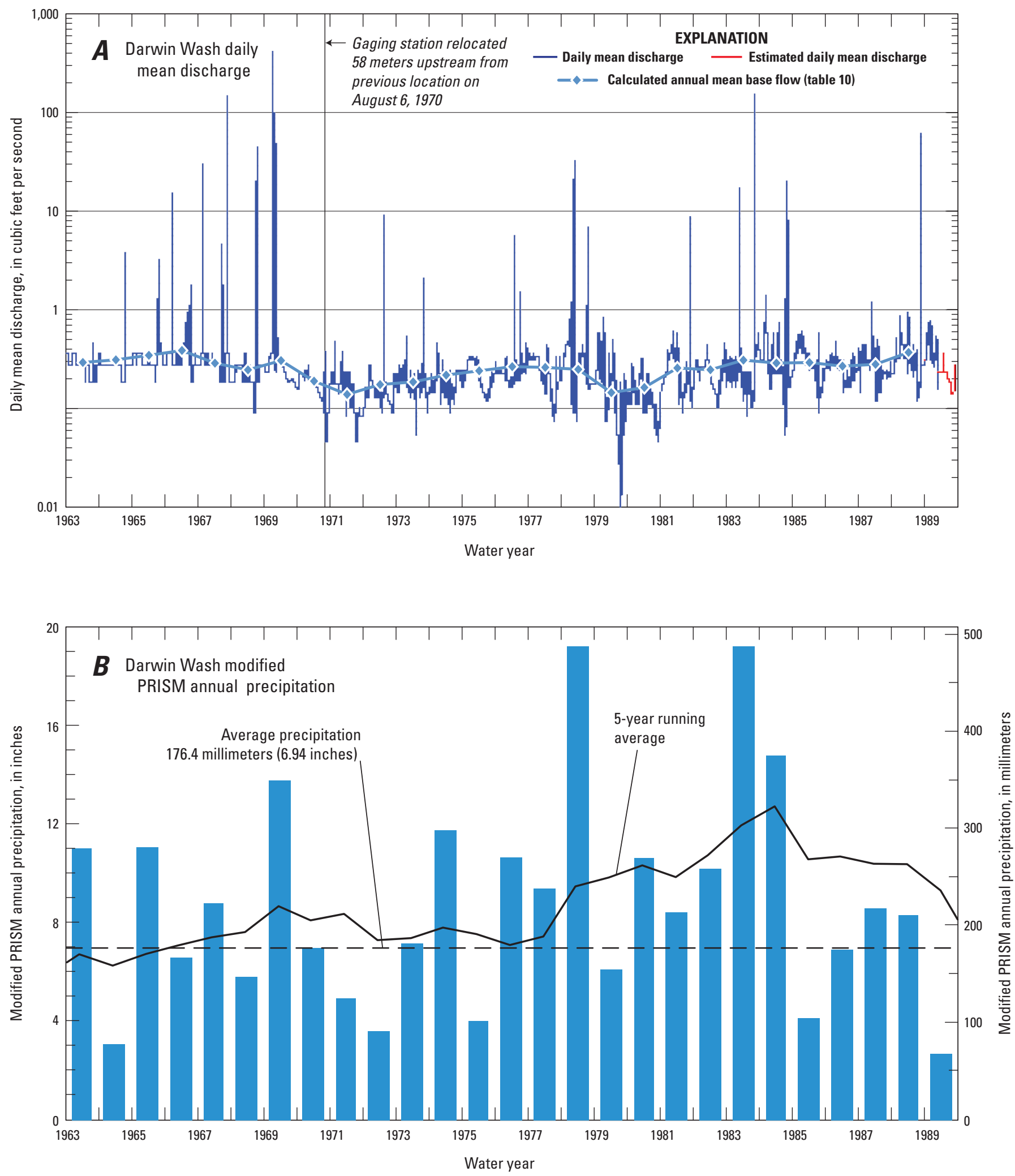

Figure 19. Comparison of daily mean discharge at the U.S. Geological Survey gaging station on Darwin Wash and modified Parameter Regression on Independent Slopes Model (PRISM) annual precipitation, Mojave Network Parks, California, 1963-89. A, Daily mean discharge. $B$, Annual precipitation. 
Table 11. Selected historical and recent instantaneous discharge collected at Darwin Wash in the Darwin Falls study area, Mojave Network Parks, California, 2005-06.

$\left[\mathrm{ft}^{3} / \mathrm{s}\right.$, cubic feet per second; gal $/ \mathrm{min}$, gallons per minute]

\begin{tabular}{lcc}
\hline \multicolumn{1}{c}{ Date } & \multicolumn{2}{c}{ Discharge } \\
\cline { 2 - 3 } & $\mathbf{f t}^{3} / \mathbf{s}$ & gal/min \\
\hline${ }^{1} 1917$ (spring) & 0.38 & 171 \\
${ }^{1} 1921$ (fall) & 0.30 & 135 \\
${ }^{1} 06 / 20 / 1928$ & 0.37 & 166 \\
${ }^{2} 05 / 06 / 2005$ & 0.25 & 110 \\
${ }^{2} 09 / 24 / 2005$ & 0.19 & 84 \\
${ }^{2} 04 / 15 / 2006$ & 0.20 & 88 \\
${ }^{2} 09 / 22 / 2006$ & 0.16 & 71 \\
\hline
\end{tabular}

${ }^{1}$ Data from Reaburn and Bowen (1928) at unknown location.

${ }^{2}$ Data from this study.

monitoring probes. Hoffman and others (1990, p.37) noted that, as measured from floodmarks, the maximum stage at the gaging station was $6.2 \mathrm{~m}$, and the date and discharge for that event are unknown. The Darwin Wash gaging station was discontinued in 1989, so the flood discharge during October 2005 was not measured.

\section{Temperature}

Temperature probes were installed to record water temperature at China Garden Spring, Darwin Upper Falls, Darwin Falls, Darwin Wash gaging station, and the Darwin Wash downstream site, and to record air temperature at Darwin Falls in May 2005 (fig. 6). A flood in Darwin Wash between September 2005 and April 2006 destroyed the water-temperature probes at Darwin Upper Falls, Darwin Falls, and Darwin Wash gaging station (fig. 6). The water-temperature probe at China Garden Spring (fig. 6) was relocated at the incorrect depth in the pool in April 14, 2006, so all data collected after this date were deleted from the record.

China Garden Spring (fig. 6) discharges beneath a permanent pool that is about $3 \mathrm{~m}$ in diameter. Spring flow is sufficiently high, relative to the size of this pond, in that its temperature range (20.2-22.1 degrees Celsius $\left[{ }^{\circ} \mathrm{C}\right]$ ) between September 2005 and September 2006 was considerably less than the range in air temperature $\left(2.4-37.0^{\circ} \mathrm{C}\right)$ at nearby Darwin Falls (fig. 20). Water temperature from Darwin Spring was restricted to the four measurements obtained when water-quality samples were collected, and ranged from 21.5 to $22.1{ }^{\circ} \mathrm{C}$ (table 2). The mean water temperature was about $22{ }^{\circ} \mathrm{C}$ at both China Garden Spring and Darwin Spring (table 2; fig. 20). Temperature records of springs that correlate with seasonal air temperatures indicate a conduit type of recharge with short flow paths, whereas springs with constant temperatures indicate recharge through a porous medium with a long flow path
(Mazor, 1991). The constant temperature measured at China Garden Spring (fig. 20) and the small range in temperatures measured at Darwin Spring (table 2) indicate that recharge is through a porous medium with a long flow path. Isotope data, presented in the "Altitude, Temperature, and Age of Recharge" section in Chapter B of this report, were used to estimate the altitude, temperature, and age of recharge to Darwin Spring (fig. 6).

Maximum summer water temperatures measured at Darwin Upper Falls and Darwin Falls were about $15^{\circ} \mathrm{C}$ less than the maximum air temperature (fig. 20) because the streamflow in Darwin Wash consisted predominately of groundwater that had discharged in Darwin Canyon (fig. 6). In addition, shading by trees in Darwin Canyon and along Darwin Wash likely helps maintain relatively cool summer water temperatures downstream of Darwin Falls (figs. 6 and 20).

\section{Water Quality}

Salinity, as indicated by the proxies EC and ROE, increased in a downgradient direction (tables 2 and 3). EC and ROE were several percent less in China Garden Spring (fig. 2; mean EC of 572 microsiemens per centimeter $[\mu \mathrm{S} / \mathrm{cm}]$ and ROE of $408 \mathrm{mg} / \mathrm{L}$ ) than in Darwin Spring (fig. 2; mean $\mathrm{EC}$ of $589 \mu \mathrm{S} / \mathrm{cm}$ and ROE of $426 \mathrm{mg} / \mathrm{L}$ ) and were several percent lower in Darwin Spring than in Darwin Falls (fig. 2; mean EC of $628 \mu \mathrm{S} / \mathrm{cm}$ and ROE of $460 \mathrm{mg} / \mathrm{L}$; tables 2 and 3 ). Evapotranspiration as water moves downgradient is one possible explanation for this spatial trend. Small amounts of evaporation are difficult to detect, but increases in $\delta \mathrm{D}$ and $\delta^{18} \mathrm{O}$ (table 6) that were observed in a downgradient direction are consistent with small amounts of evaporative concentration. (See the "Stable isotopes" section of appendix 1 for a discussion on isotope enrichment caused by evaporation.) It also is possible that the groundwater that emerges at each location has flowed through different material, or through the same deposits, but in differing proportional contributions. Major-ion composition (table 3), Sr-isotope ratios (table 6), and concentrations for nearly all trace elements (table 5) were virtually indistinguishable among the sites, indicating that the groundwater flowed through similar geologic material at all sampled periods and locations. Two exceptions are As and Ba. Concentrations of As ranged from 47.7 to $51.4 \mu \mathrm{g} / \mathrm{L}$ at China Garden and Darwin Springs, and from 32.1 to $35.8 \mu \mathrm{g} / \mathrm{L}$ in Darwin Falls (table 5; fig. 2), which exceeds the U.S. Environmental Protection Agency (EPA) maximum contaminant level (MCL) of $10 \mu \mathrm{g} / \mathrm{L}$ for potable water (U.S. Environmental Protection Agency, 2010). Concentrations of Ba ranged from 12.4 to $14.9 \mu \mathrm{g} / \mathrm{L}$ at China Garden and Darwin Springs (fig. 2), and from 25.0 to $30.0 \mu \mathrm{g} / \mathrm{L}$ at Darwin Falls (table 5; fig. 2). This indicates that differences, albeit slight, do exist in the mineral and rock deposits through which groundwater flows from its source of recharge to China Garden Spring, Darwin Spring, and Darwin Falls (fig. 2). 


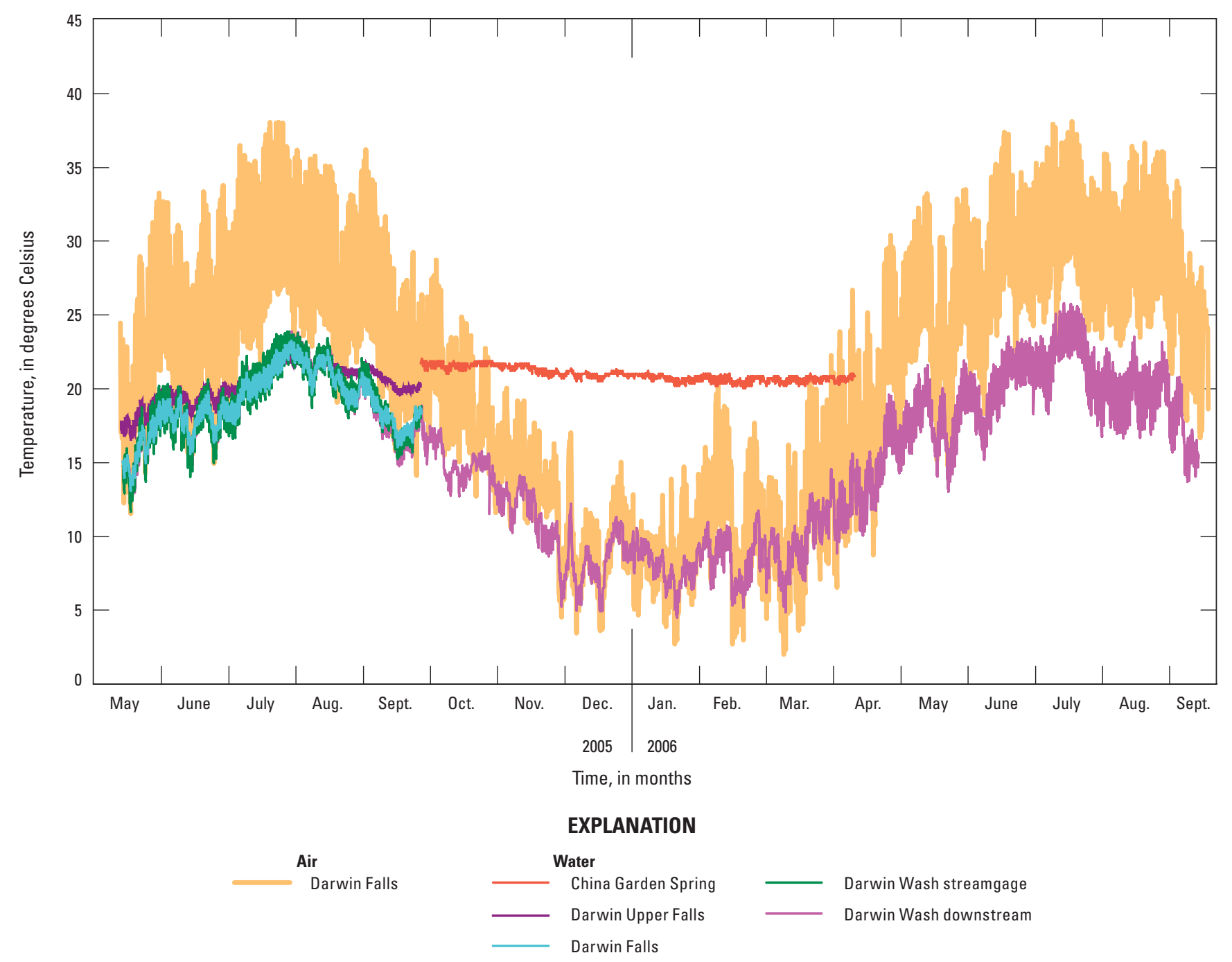

Figure 20. Air and water temperatures at the Darwin Falls study area, Mojave Network Parks, California, 2005-06.

Large differences in concentrations of biologically active constituents (such as DO, Fe, and $\mathrm{Mn}$ ) were measured between sampling dates at Darwin Spring (fig. 2; tables 2 and 5). These constituents are sensitive to redox conditions (Hem, 1989), which could explain the variance in measurements. Because NPS regulations did not allow the permanent emplacement of a piezometer to sample the spring, continuous measurements could not be collected throughout the study period, and measurements only were made when study personnel visited the site. Reinstallation of the temporary piezometer for each site visit resulted in extreme variation in pumped discharge from the piezometer-with anywhere from less than a minute to more than an hour required to fill a 1-L sample container. These factors probably contributed to the variability in the constituents sensitive to redox conditions. Fortunately, this had virtually no effect on concentration for most of the constituents (tables 2 and 5).

\section{Altitude, Temperature, and Age of Recharge}

The source of water for the springs sampled in the Darwin Falls area is considered to be the infiltration of precipitation in the Coso and Argus Ranges that surround the Darwin Falls drainage basin (fig. 2). Water isotopes were used to estimate an average altitude of recharge by using equation 2 as described in the "Stable Isotopes" section of appendix 1. The estimated average altitude of recharge to Darwin Spring was 2,348 $\mathrm{m}$ (table 12), 1,415.3 $\mathrm{m}$ higher (table 12) than the altitude of the spring ( $932.7 \mathrm{~m}$; table 1); the altitude of recharge is based on the spring's mean $\delta \mathrm{D}$ of -103.8 per mil (table 6). The estimated average altitude of recharge $(2,348 \mathrm{~m}$; table 12) indicates that most of the spring water recharged along the flanks of the Coso and Argus Ranges (fig. 2). The calculated altitude of recharge could overestimate the actual altitude of recharge for the samples because water ages from 
Table 12. Summary of average altitude of recharge estimated using water isotopes for Darwin Spring, Piute Spring, Piute Seep, and the Upper Pool at the Fortynine Palms Oasis, Mojave Network Parks, California, 2005-06.

[See figures 6, 11, and 16 for site locations and table 6 for data; altitude of land surface, in meters or feet above sea level, which refers to the North American Vertical Datum of 1988 (NAVD 88); Difference refers to average recharge altitude in meters or feet minus the spring altitude in meters or feet; $\mathrm{m}$, meters; $\mathrm{ft}$, feet]

\begin{tabular}{lcccccc}
\hline \multicolumn{1}{c}{$\begin{array}{c}\text { Report } \\
\text { site name }\end{array}$} & $\begin{array}{c}\text { Spring } \\
\text { altitude } \\
(\mathbf{m})\end{array}$ & $\begin{array}{c}\text { Spring } \\
\text { altitude } \\
(\mathbf{f t})\end{array}$ & $\begin{array}{c}\text { Average recharge } \\
\text { altitude } \\
(\mathbf{m})\end{array}$ & $\begin{array}{c}\text { Average recharge } \\
\text { altitude } \\
\text { (ft) }\end{array}$ & $\begin{array}{c}\text { Difference } \\
\text { (m) }\end{array}$ & $\begin{array}{c}\text { Difference } \\
\text { (ft) }\end{array}$ \\
\hline Darwin Spring & 932.7 & 3,060 & 2,348 & 7,703 & $1,415.3$ \\
Piute Spring & 901.6 & 2,958 & 1,668 & 5,472 & 766.4 & 2,643 \\
Piute Seep & 878.7 & 2,883 & 1,663 & 5,456 & 784.3 \\
Upper Pool & 857.4 & 2,813 & 1,400 & 4,593 & 2,573 \\
\hline
\end{tabular}

these samples, described in the following paragraphs, indicate that recharge occurred thousands of years ago when the climate in the drainage basin could have been colder, wetter, or both, which would cause isotope ratios to be lighter (more negative) than modern (present time or recent) precipitation (Smith and others, 1992). If the isotope ratios of the recharge precipitation were lighter than modern precipitation, then the difference between the isotope ratios of the spring and of the recharge precipitation would be less, which would result in a lower estimated altitude of recharge (equation 2; appendix 1). In any case, the isotopic data indicate that most of the spring water was recharged at a much higher altitude than Darwin Spring (fig. 2).

Recharge temperatures calculated by using noble gases were $16.4{ }^{\circ} \mathrm{C}$ and $16.1{ }^{\circ} \mathrm{C}$ for two samples collected from Darwin Spring during 2005 (table 8; method referenced in "Noble Gases" section of appendix 1). Recharge temperature calculated by using the $\mathrm{N}_{2}$ and Ar gases (table 7; method referenced in "Common Atmospheric Gases" section of appendix 1) averaged $14.6^{\circ} \mathrm{C}$ (range is $13.3-15.9^{\circ} \mathrm{C}$ ) from the four sample collections in 2005 and 2006 at Darwin Spring, which is only slightly cooler than average temperature of water samples collected from Darwin Falls $\left(14.9^{\circ} \mathrm{C}\right.$ [range is 12.9-16.5 ${ }^{\circ} \mathrm{C}$; ; table 2). Installation of a permanent piezometer extending to a greater depth at Darwin Spring could improve accuracy and precision, although the results obtained from separate collection on dates already are in reasonable agreement with one another. The cooler recharge temperatures calculated by using the noble gas data for Darwin Spring and Darwin Falls indicate that the recharge to these areas is not local recharge but rather recharge at higher altitudes in the drainage basin, which supports the higher altitude of recharge calculated from the stable isotope data.

Age of the groundwater discharged at a spring is one of the most important attributes, with respect to evaluating the sustainability of the resource and its potential vulnerability to climate change and human effects (Mazor, 1991). A spring sustained by groundwater that was recharged days or years ago (young groundwater) will respond to changes in quantity and quality of that recharge more rapidly than a spring sustained by groundwater that was recharged hundreds to thousands of years ago (old groundwater). There will be a long time lag (decades) between when a stress (recharge or pumpage) is changed in a large groundwater system and when it is observed at a spring a long distance (tens of kilometers) from where the stress to the system was changed (Bredehoeft and Durbin, 2009). Therefore, knowledge of the age of water is essential for effective groundwater management (Mazor, 1991).

Two samples from Darwin Spring (fig. 2) collected in September 2005 and April 2006 yielded a calculated ${ }^{14} \mathrm{C}$ age of 8,815 and 9,817 years, respectively (table 6). However, the high values of $\delta^{13} \mathrm{C}$ for both samples (table 6) indicate exchange with $\mathrm{C}$ containing no ${ }^{14} \mathrm{C}$ in the soil. A two-member mixing model to adjust for this exchange (Mazor, 1991), as described in the "Radioactive Isotopes" section of appendix 1, yielded a corrected ${ }^{14} \mathrm{C}$ of 2,899 and 3,065 years, respectively, for these two samples (table 6). Such old groundwater ages are consistent with little change in water quality and isotopic composition (Mazor, 1991) that was observed between sample periods at Darwin Spring and Darwin Falls (fig. 2; tables 3-6). Seasonal changes in water quality along Darwin Wash (fig. 2) probably only occur during major flood events where local runoff is a primary source of water to the creek. However, no samples were collected during major flood events to determine if there was variation in water quality associated with these events.

\section{Piute Spring, Mojave National Preserve}

Five USGS monitoring sites were established in the Piute Spring study area in the Mojave National Preserve to evaluate the hydrogeology and water quality of the riparian habitat of the Piute Spring area: Piute Spring, Upper Piute Creek, Middle Piute Creek, Piute Seep, and Lower Piute Creek (fig. 11). The sites were monitored for discharge, air temperature, water temperature, and (or) water quality depending on the conditions and location of the site (table 1; fig. 11). 


\section{Discharge}

Piute Spring is the farthest upstream source of spring discharge to Piute Creek (fig. 9). As the creek flows through Piute Canyon (fig. 9) from Piute Spring toward the Middle Piute Creek monitoring site, it gains flow from additional groundwater discharge farther downstream (fig. 11). Four discharge measurements made at the Middle Piute Creek site (fig. 11) ranged from $0.07 \mathrm{ft}^{3} / \mathrm{s}(31 \mathrm{gal} / \mathrm{min})$ in May 2005 to 0.02 $\mathrm{ft}^{3} / \mathrm{s}(9.0 \mathrm{gal} / \mathrm{min}$ ) in September 2005 (table 2). The decrease in flow between May and September 2005 could be the result of a major flood event in August, which modified the stream channel. The flood repositioned the stream at Middle Piute Creek (fig. 11) to about $9 \mathrm{~m}$ south of where it had been in May 2005 and deposited sediment in the area of the old stream channel. Groundwater that formerly contributed to streamflow upstream of the Middle Piute Creek monitoring site (fig. 11) probably flowed through the recently deposited sediments and discharged farther downstream, and likely was not measured at the Middle Piute Creek monitoring site. Discharge at Middle Piute Creek (fig. 11) was $0.03 \mathrm{ft}^{3} / \mathrm{s}(13.5 \mathrm{gal} / \mathrm{min})$ in April 2006 and $0.02 \mathrm{ft}^{3} / \mathrm{s}$ (9.0 gal/min) in September 2006 (table 2) following the same pattern of lower discharge at the end of the summer in 2005.

The modified PRISM annual precipitation also decreased from 2005 to 2006, indicating that the discharge and precipitation both decreased between the first and second year of the study (figs. $18 B$ and 21). Comparison of the measured discharges to the modified PRISM annual precipitation for the Piute Spring drainage basin indicates that the creek discharge in the early spring is related to the annual precipitation, which predominantly occurs during the winter and spring months; however, the late summer discharge collected several months later indicates little relation to precipitation (fig. 18B). Precipitation and discharge would need to be collected on a monthly basis for at least 5 years to determine if there is a trend between precipitation and discharge (Schertz and others, 1991).

Freiwald (1984) reported historical discharges on Piute Creek (fig. 9) ranging between less than $0.01 \mathrm{ft}^{3} / \mathrm{s}$ (4.5 gal/min) in January 1909 to $0.87 \mathrm{ft}^{3} / \mathrm{s}(390 \mathrm{gal} / \mathrm{min})$ in April 1980 (table 13) for a study of Lanfair Valley to the west (fig. 7). Direct comparison with data collected for this study is not possible because location of these discharge measurements was not documented, and days elapsed since each previous precipitation event was not recorded.

Numerous instantaneous discharge measurements were made between 1987 and 2003 at two locations on Piute Creek (table 13; fig. 9) in response to regulatory requirements related to the Viceroy Gold Corporation gold mine in the Castle Mountains, which is approximately $20 \mathrm{~km}$ northwest of Piute Spring (fig. 7; M.E. Kazelskis, Project Geologist, Broadbent and Associates, Inc., written commun., 2001). Although the exact locations of the discharge measurements were not documented, the upstream monitoring site was between Piute Spring and Upper Piute Creek, and the downstream site was approximately $6 \mathrm{~m}$ downstream from the partially destroyed old concrete Piute Dam (near Lower Piute Creek; fig. 11) where the creek splits into two channels. Discharge collected in response to regulatory requirements related to the Viceroy Gold Corporation gold mine at the upstream site ranged from 0.05 to $0.25 \mathrm{ft}^{3} / \mathrm{s}$ (21 to $114 \mathrm{gal} / \mathrm{min}$ ) and averaged $0.10 \mathrm{ft}^{3} / \mathrm{s}$ (44 gal/min); whereas, discharge on the same day at the downstream site ranged from 0.05 to $0.93 \mathrm{ft}^{3} / \mathrm{s}$ ( 21 to $418 \mathrm{gal} / \mathrm{min}$ ) and averaged $0.30 \mathrm{ft}^{3} / \mathrm{s}(137 \mathrm{gal} / \mathrm{min}$; table 13). The average discharge of the upstream monitoring site $\left(0.10 \mathrm{ft}^{3} / \mathrm{s}\right.$ [44 gal/ min]) was similar to the discharge measured at Middle Piute Creek in May $2005\left(0.07 \mathrm{ft}^{3} / \mathrm{s}\right.$ [31 gal/min]), but was substantially greater than the discharge measured at Middle Piute Creek after the flood in August 2005 (figs. 11 and 22). Discharge at both sites was greater in the fall and winter than in the spring and summer (table 13; fig. 22) likely because more precipitation falls in the fall and winter, and evapotranspiration is higher in the spring and summer.

Discharge measurements collected by the Viceroy Gold Corporation (M.E. Kazelskis, Project Geologist, Broadbent and Associates, Inc., written commun., 2001) indicated only small seasonal differences at the upstream site near Piute Spring (figs. 7 and 22), but larger seasonal differences at the downstream site near the old dam (fig. 22). Data from the downstream site indicated that a change affecting discharge occurred between 1992 and 1993 (fig. 22). Summer discharge averaged about $0.10 \mathrm{ft}^{3} / \mathrm{s}(47 \mathrm{gal} / \mathrm{min})$ before 1993 and about $0.33 \mathrm{ft}^{3} / \mathrm{s}(150 \mathrm{gal} / \mathrm{min})$ after 1993 . Comparison of the modified PRISM annual precipitation in the Piute drainage basin (fig. 7) to measured discharge on Piute Creek indicates that precipitation did not increase between 1992 and 1993, and therefore cannot explain the observed increase in discharge (fig. 22). However, the large amount of precipitation in 1992 (fig. 22) might have produced floods that scoured the stream channel, lowered the streambed altitude at the downstream measuring site near Piute Dam (fig.11), and resulted in more groundwater discharge to Piute Creek and less groundwater underflow at the downstream site. Comparison of summer discharge data from 1993 to 2003 indicates that Piute Creek (fig. 9) gained an average of about $0.24 \mathrm{ft}^{3} / \mathrm{s}(109 \mathrm{gal} / \mathrm{min})$ between the upstream and downstream sites (table 13; fig. 22).

\section{Temperature}

Water-temperature probes were installed at Upper Piute Creek, Middle Piute Creek, Piute Seep, and Lower Piute Creek, and an air-temperature probe was installed at Middle Piute Creek in May 2005 (fig. 11). A flood in Piute Canyon (fig. 9) during August 2005 destroyed all of the water-temperature probes. Replacement water-temperature probes were installed at Middle Piute Creek and Piute Seep in September 2005, and at Upper and Lower Piute Creek in February 2006 (fig. 11). A flood in Piute Canyon (fig. 9) between April and August 2005 destroyed the watertemperature probes at Upper and Lower Piute Creek (fig. 11). 

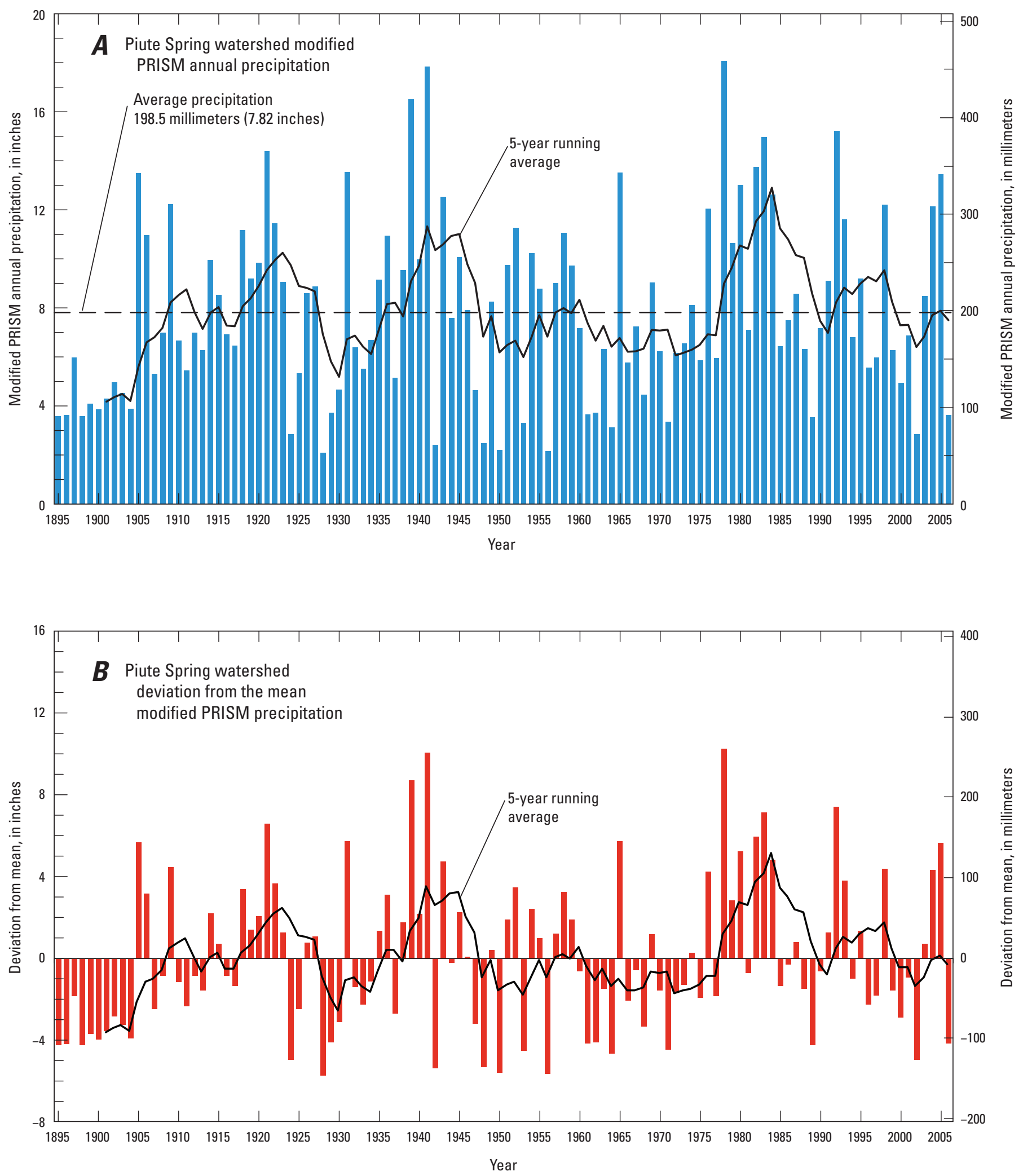

Figure 21. Modified Parameter Regression on Independent Slopes Model (PRISM) annual precipitation and deviation from the mean for Piute Spring drainage basin, Mojave Network Parks, 1895-2006. A, Annual precipitation. B, Deviation from the mean. 
Table 13. Historical instantaneous discharge collected at the Piute Spring study area, Mojave Network Parks, California, 1909-2003.

[1906-82 data from Freiwald (1984); 1987-2003 data from M.E. Kazelskis, Project Geologist, Broadbent and Associates, Inc., written commun., 2001; ft³/s, cubic feet per second; gal/min, gallons per minute; <, less than value shown; -, no data; xx/xx/xxxx, month/day/year]

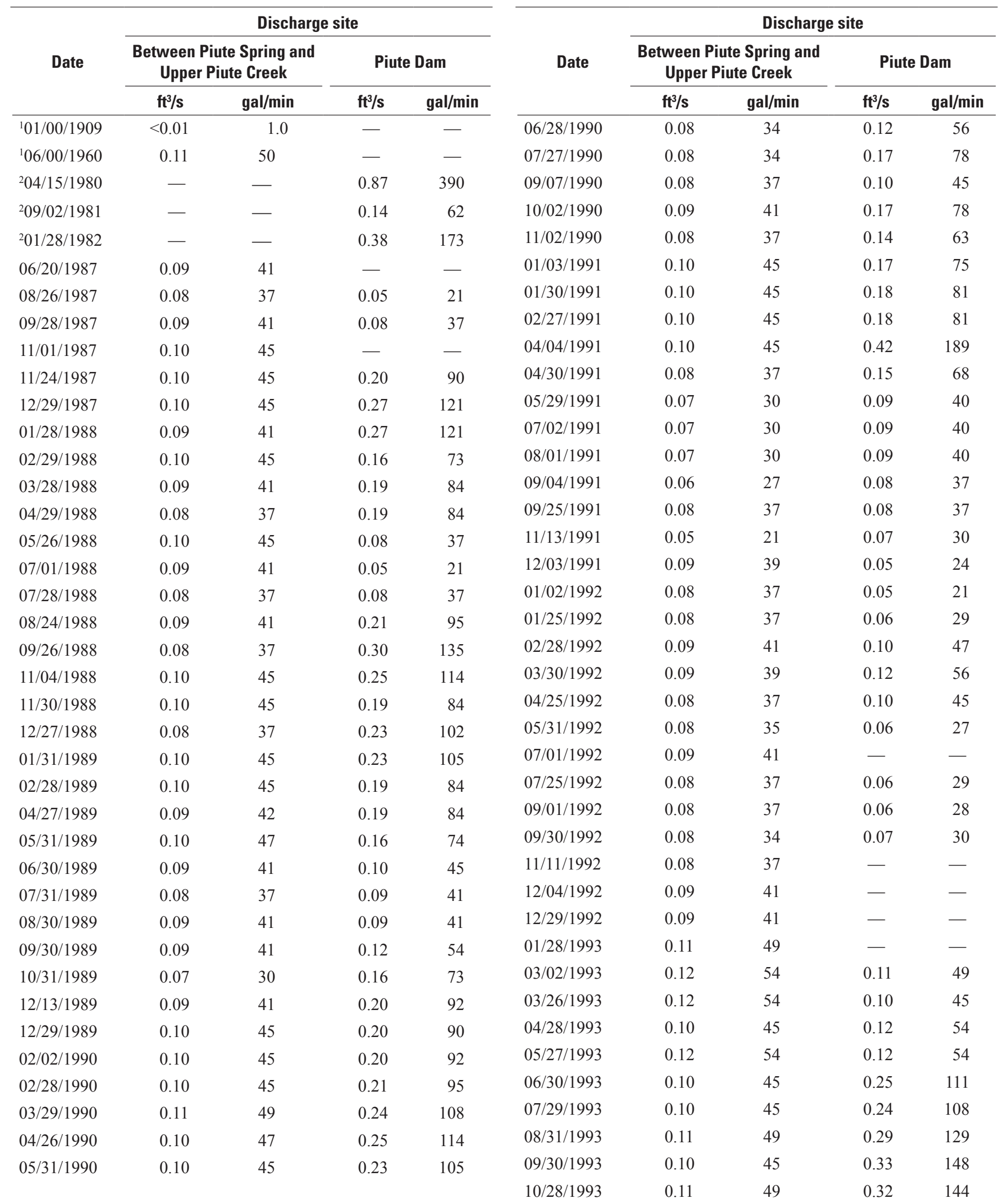


Table 13. Historical instantaneous discharge collected at the Piute Spring study area, Mojave Network Parks, California, 1909-2003.-Continued

[1906-82 data from Freiwald (1984); 1987-2003 data from M.E. Kazelskis, Project Geologist, Broadbent and Associates, Inc., written commun., 2001; ft³, cubic feet per second; gal/min, gallons per minute; <, less than value shown; —, no data; xx/xx/xxxx, month/day/year]

\begin{tabular}{|c|c|c|c|c|c|c|c|c|c|}
\hline \multirow[b]{2}{*}{ Date } & \multicolumn{4}{|c|}{ Discharge site } & \multirow[b]{2}{*}{ Date } & \multicolumn{4}{|c|}{ Discharge site } \\
\hline & \multicolumn{2}{|c|}{$\begin{array}{c}\text { Between Piute Spring and } \\
\text { Upper Piute Creek }\end{array}$} & \multicolumn{2}{|c|}{ Piute Dam } & & \multicolumn{2}{|c|}{$\begin{array}{c}\text { Between Piute Spring and } \\
\text { Upper Piute Creek }\end{array}$} & \multicolumn{2}{|c|}{ Piute Dam } \\
\hline $11 / 30 / 1993$ & 0.10 & 45 & 0.32 & 145 & $02 / 26 / 1997$ & 0.09 & 41 & 0.70 & 314 \\
\hline $12 / 29 / 1993$ & 0.13 & 58 & 0.35 & 155 & $03 / 25 / 1997$ & 0.11 & 49 & 0.52 & 233 \\
\hline 03/30/1994 & 0.11 & 49 & 0.36 & 163 & 06/30/1997 & 0.09 & 41 & 0.42 & 189 \\
\hline 04/28/1994 & 0.07 & 30 & 0.17 & 78 & $07 / 30 / 1997$ & 0.09 & 41 & 0.38 & 172 \\
\hline 05/31/1994 & 0.10 & 45 & 0.27 & 121 & 09/04/1997 & 0.09 & 41 & 0.46 & 206 \\
\hline 06/29/1994 & 0.11 & 49 & 0.23 & 101 & 09/24/1997 & 0.10 & 45 & 0.44 & 197 \\
\hline 10/27/1994 & 0.12 & 54 & 0.40 & 180 & $01 / 28 / 1998$ & 0.19 & 84 & 0.54 & 242 \\
\hline $11 / 30 / 1994$ & 0.10 & 45 & 0.48 & 215 & $02 / 26 / 1998$ & 0.17 & 78 & 0.54 & 242 \\
\hline $12 / 27 / 1994$ & 0.12 & 54 & 0.52 & 233 & $03 / 31 / 1998$ & 0.09 & 41 & 0.46 & 206 \\
\hline 01/31/1995 & 0.11 & 49 & 0.70 & 314 & $06 / 23 / 1998$ & 0.11 & 49 & 0.42 & 189 \\
\hline 02/28/1995 & 0.09 & 41 & 0.63 & 282 & $09 / 22 / 1998$ & 0.07 & 30 & 0.33 & 149 \\
\hline 03/28/1995 & 0.10 & 45 & 0.68 & 303 & $12 / 15 / 1998$ & 0.07 & 30 & 0.46 & 206 \\
\hline $04 / 27 / 1995$ & 0.11 & 49 & 0.70 & 314 & 03/30/1999 & 0.10 & 45 & 0.42 & 189 \\
\hline 05/31/1995 & 0.08 & 37 & 0.58 & 262 & 06/29/1999 & 0.11 & 49 & 0.33 & 149 \\
\hline 06/28/1995 & 0.08 & 37 & 0.50 & 224 & 09/28/1999 & 0.08 & 37 & 0.40 & 180 \\
\hline $12 / 20 / 1995$ & 0.11 & 49 & 0.48 & 215 & $03 / 27 / 2001$ & 0.20 & 90 & 0.68 & 303 \\
\hline 01/31/1996 & 0.10 & 45 & 0.50 & 224 & $06 / 20 / 2001$ & 0.09 & 41 & 0.33 & 149 \\
\hline 02/28/1996 & 0.10 & 45 & 0.44 & 197 & 09/18/2001 & 0.06 & 27 & 0.30 & 135 \\
\hline 03/26/1996 & 0.10 & 45 & 0.38 & 172 & $12 / 20 / 2001$ & 0.09 & 41 & 0.93 & 418 \\
\hline 04/30/1996 & 0.11 & 49 & 0.32 & 142 & $03 / 27 / 2002$ & 0.13 & 58 & 0.57 & 257 \\
\hline 05/30/1996 & 0.08 & 37 & 0.33 & 149 & $06 / 26 / 2002$ & 0.08 & 37 & 0.33 & 149 \\
\hline 06/26/1996 & 0.08 & 37 & 0.37 & 164 & $09 / 25 / 2002$ & 0.08 & 37 & 0.32 & 142 \\
\hline 07/31/1996 & 0.09 & 41 & 0.40 & 180 & $12 / 18 / 2002$ & 0.15 & 68 & 0.52 & 233 \\
\hline 08/28/1996 & 0.06 & 27 & 0.33 & 149 & $04 / 09 / 2003$ & 0.08 & 37 & 0.35 & 157 \\
\hline 09/25/1996 & 0.08 & 37 & 0.37 & 164 & $07 / 02 / 2003$ & 0.08 & 34 & 0.32 & 142 \\
\hline 10/30/1996 & 0.10 & 45 & 0.44 & 197 & $09 / 30 / 2003$ & 0.10 & 45 & 0.33 & 149 \\
\hline $11 / 25 / 1996$ & 0.11 & 49 & 0.52 & 233 & ${ }^{1}$ Discharge & mated. Loca & f measurement & specific & \\
\hline $12 / 17 / 1996$ & 0.10 & 45 & 0.58 & 262 & ${ }^{2}$ Discharge & sured about & ters upstream & Piute & (near \\
\hline 01/28/1997 & 0.08 & 37 & 0.72 & 324 & & & & & \\
\hline
\end{tabular}




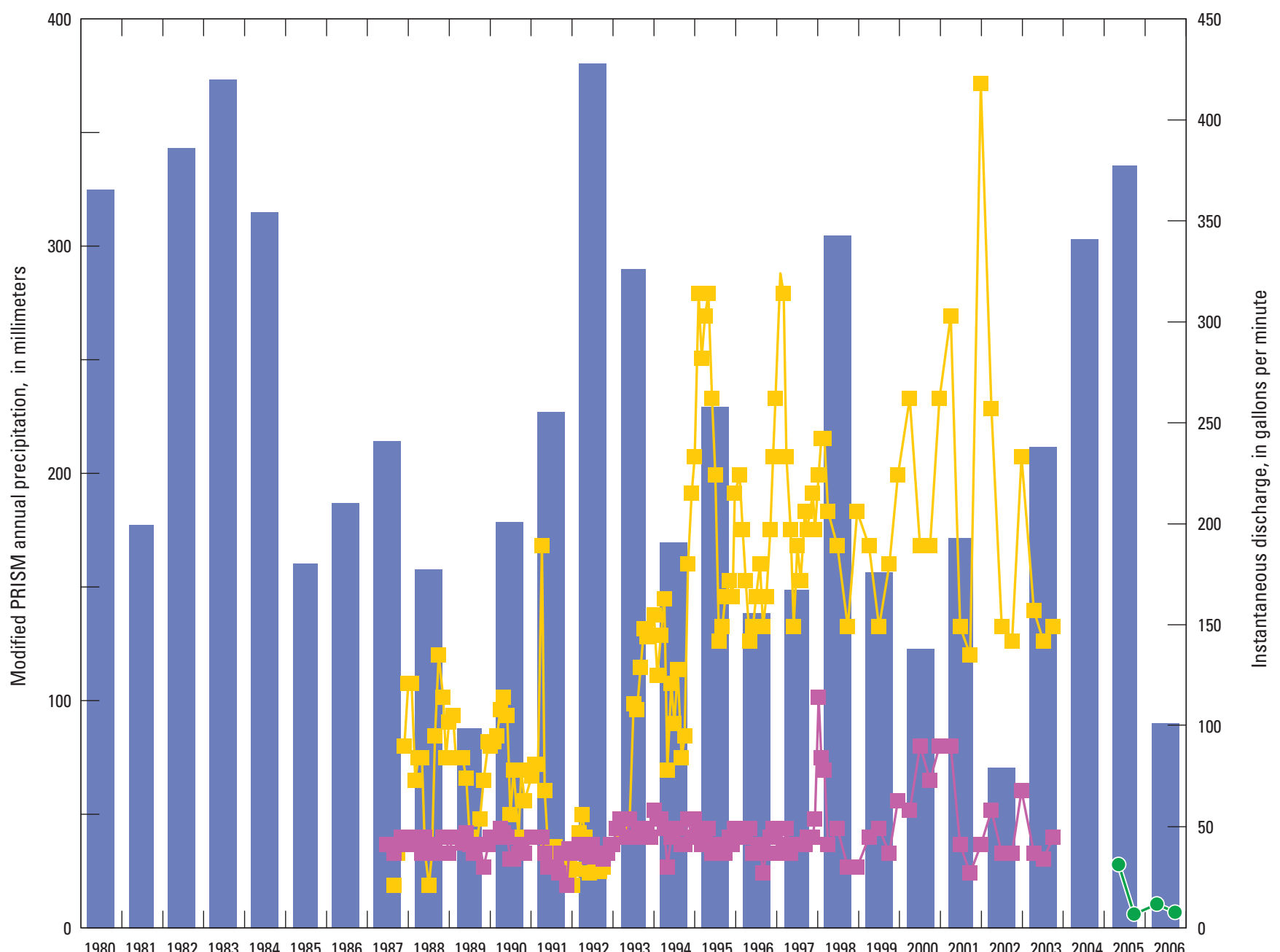

198019811982198319841985198619871988198919901991199219931994199519961997199819992000200120022003200420052006

Year

\section{EXPLANATION}

Precipitation

Modified PRISM

annual precipitation
Instantaneous discharge

Data collected for this study

- - Middle Piute Creek

Data collected by Viceroy Gold Corporation

- Between Piute Spring and Middle Piute Creek

_- Piute Dam (destroyed)

Figure 22. Discharge for Piute Creek collected by the Viceroy Gold Corporation, 1987-2000, and modified Parameter Regression on Independent Slopes Model (PRISM) annual precipitation, 1980-2000, Mojave Network Parks, California. 
Piute Spring (fig. 11) was not easily accessible until the flood in 2005 eliminated much of the vegetation; hence, the only water temperature obtained for the spring itself was $27.6^{\circ} \mathrm{C}$ on September 19,2006 , which is a value that is notably higher than both Middle Piute Creek $\left(22.9^{\circ} \mathrm{C}\right)$ and Piute Seep $\left(25.7^{\circ} \mathrm{C}\right)$ on the same day (fig. 11 ; table 2$)$. The flood removed much of the vegetation surrounding Piute Creek in Piute Canyon (fig. 10D), so it is possible that the spring water was heated by the sun heating the overlying exposed soil.

Air-temperature data, recorded at 15 -minute intervals from May 2005 to September 2006, indicated air temperature had a range of $43.8^{\circ} \mathrm{C}$ (ranged from -0.8 to $43.0^{\circ} \mathrm{C}$ ), which was nearly 4 -fold greater than the range in water temperature recorded at 1-hour intervals at Middle Piute Creek and Piute Seep (figs. 11 and 23). Water temperatures at Upper Piute Creek and at Lower Piute Creek followed the air temperature more closely than water temperatures at Piute Seep or Middle Piute Creek (figs. 11 and 23). It is possible that water temperatures were attenuated at Middle Piute Creek, because flow reemerged from beneath the streambed only a short distance upstream, and at Piute Seep because groundwater seeps from the base of a nearby hill (fig. 11).

\section{Water Quality}

The interpretation of water-quality differences among sampling sites and between successive samples was compromised by inaccessibility of Piute Spring (fig. 11) until the last of the four planned sampling trips. The Piute Creek (fig. 11) stream channel migrated from one side of the canyon to the other following a flood after the first year of sampling was completed, and the Piute Seep (fig. 11) moved to a slightly different location after the flood. The available data indicate that EC was about 20 percent less at Piute Spring compared to Middle Piute Creek (fig. 11; table 2), and primarily reflected lower $\mathrm{Ca}, \mathrm{Cl}$, and $\mathrm{SO}_{4}$ concentrations (table 3 ). However, differences in Sr-isotope ratios among all sampling sites (table 6) were not evident. These results are consistent with seepage of a uniform groundwater source to Piute Creek at multiple locations down Piute Canyon (fig. 9) with minor evaporative concentration as indicated by isotopic values becoming heavier (less negative) in a downgradient direction (table 6).

Water-quality results from the compliance monitoring required in Piute Creek (fig. 11), described previously, are reproduced in appendix 2 (M.E. Kazelskis, Project Geologist, Broadbent and Associates, Inc., written commun., 2001). The water-quality samples were collected about $6 \mathrm{~m}$ downstream from the partially destroyed old concrete Piute Dam (near Lower Piute Creek; fig. 11). The monitoring data for EC and As concentrations indicated variability, but no discernible temporal trend (fig. 24). Comparison of the compliance monitoring data (appendix 2) and a single sample collected in 1981 by the USGS (table 14) to data collected for this study (tables 5-7) indicates that, with the possible exception of $\mathrm{N}$ as discussed in the "Site Comparisons" section, water-quality in Piute Creek (fig. 11) did not change appreciably for 25 years.

A single sample was collected in May 2006 for analysis of polar (water soluble) pesticides at Middle Piute Creek (fig. 11) because the herbicide, trichlopyr, was known to have been used in Piute Canyon for eradication of salt cedar (Tamarix ramosissima.; table 9). Although triclopyr and its primary metabolites have been reported to have aquatic degradation half-lives of only a few days (Getsinger and others, 2000), somewhat longer persistence could be anticipated because the herbicide was applied in a nonpolar petroleum emulsion following the fire in Piute Canyon (fig. 9). Trichlopyr was not detected in the sample (table 9); the laboratory reporting level (LRL; $0.03 \mu \mathrm{g} / \mathrm{L}$ ) is far below the effect levels (about $105 \mu \mathrm{g} / \mathrm{L}$ ) on frogs and tadpoles determined by other studies (Berrill and others, 1994; Perkins and others, 2000; Durkin and Diamond, 2002).

\section{Altitude, Temperature, and Age of Recharge}

The source of water for the springs sampled in the Piute Spring study area is believed to be the infiltration of precipitation in the New York Mountains and Piute Range that border Lanfair Valley (fig. 7). Water isotopes were used to estimate an average altitude of recharge in the Piute Spring drainage basin (fig. 7) by using equation 2 as described in the "Stable Isotopes" section of appendix 1 . The estimated average altitude of recharge to Piute Spring is 1,668 m (table 12), $766.4 \mathrm{~m}$ higher than the altitude of Piute Spring $(901.6 \mathrm{~m}$; table 12; fig. 7), which is based on its mean $\delta \mathrm{D}$ of -80.5 per mil (table 6). The estimated average altitude of recharge to Piute Seep is 1,663 m (table 12; fig. 11), $784.3 \mathrm{~m}$ lower than the altitude of Piute Seep (878.7 m; table 12; fig. 11), which is based on its mean $\delta \mathrm{D}$ of -80.4 per mil (table 6 ). The almost identical estimated average altitude of recharge for Piute Spring and Piute Seep implies similar sources of recharge and indicates that most of the recharge occurs along the flanks of the New York Mountains in the northwestern part of the Lanfair Valley (fig. 7). The calculated altitude of recharge could overestimate the actual altitude of recharge for samples because water ages from these samples, described later in this report, indicated recharge occurred thousands of years ago when the climate could have been colder, wetter, or both in the drainage basin, which would cause isotope ratios to be lighter (more negative) than in modern precipitation (Smith and others, 1992). If the isotope ratios of the precipitation were lighter than modern precipitation, then the difference between the isotope ratios of Piute Spring (fig. 7) and precipitation would be less, which would result in a lower estimated altitude of recharge (equation 2, appendix 1). In any case, the isotopic data indicate that most of the recharge occurs at much higher altitudes than Piute Canyon (fig. 7).

Recharge temperature calculated using noble gases (Heaton and Vogel, 1981; Aeschbach-Hertig and others, 1999; Aeschbach-Hertig and others, 2000; and Manning and Solomon, 2003) averaged $23.6{ }^{\circ} \mathrm{C}$ for two samples collected 


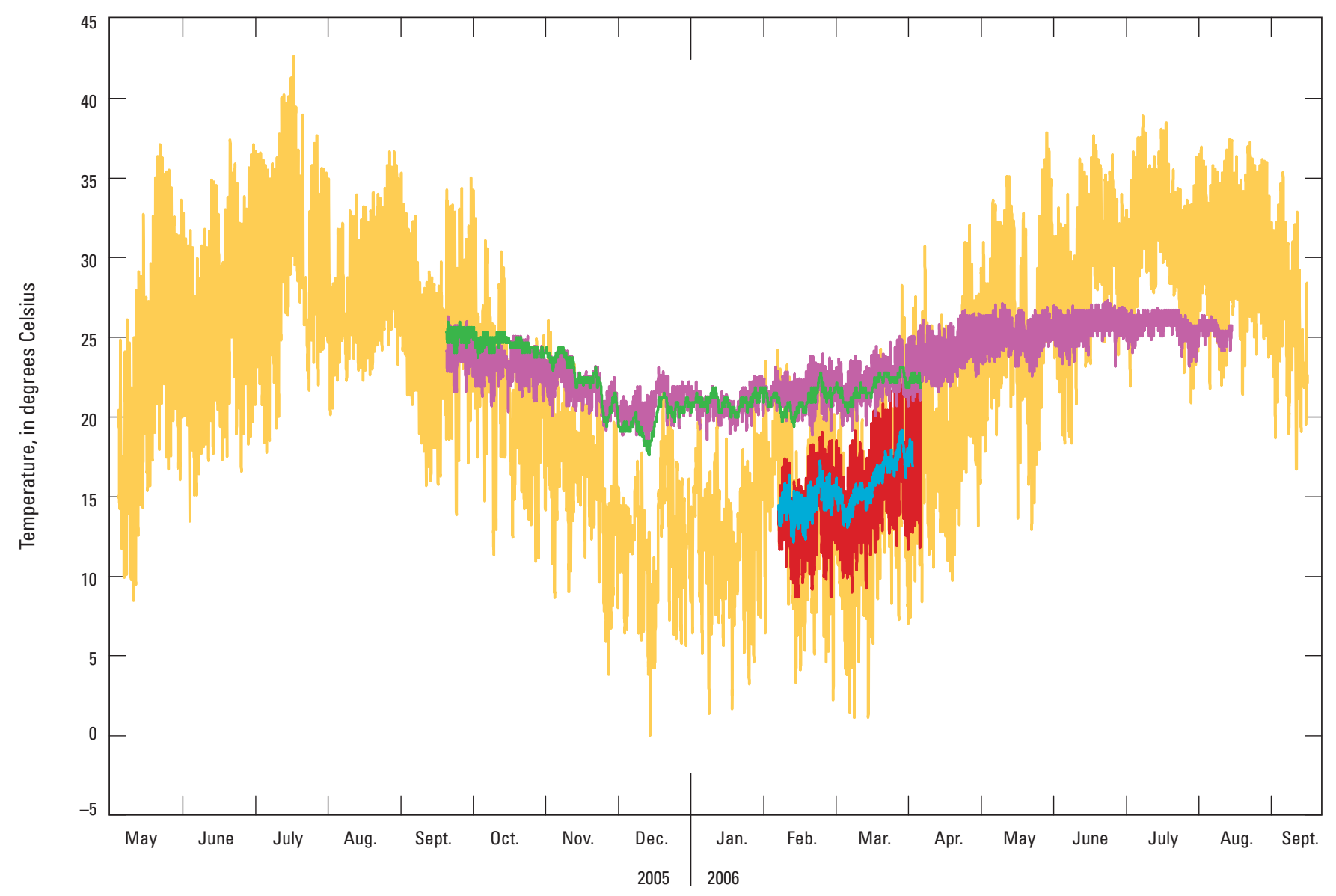

Time, in months

EXPLANATION

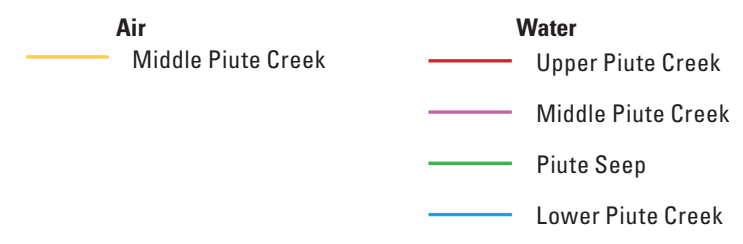

Figure 23. Air and water temperatures at the Piute Spring study area, Mojave Network Parks, California, $2005-06$. 


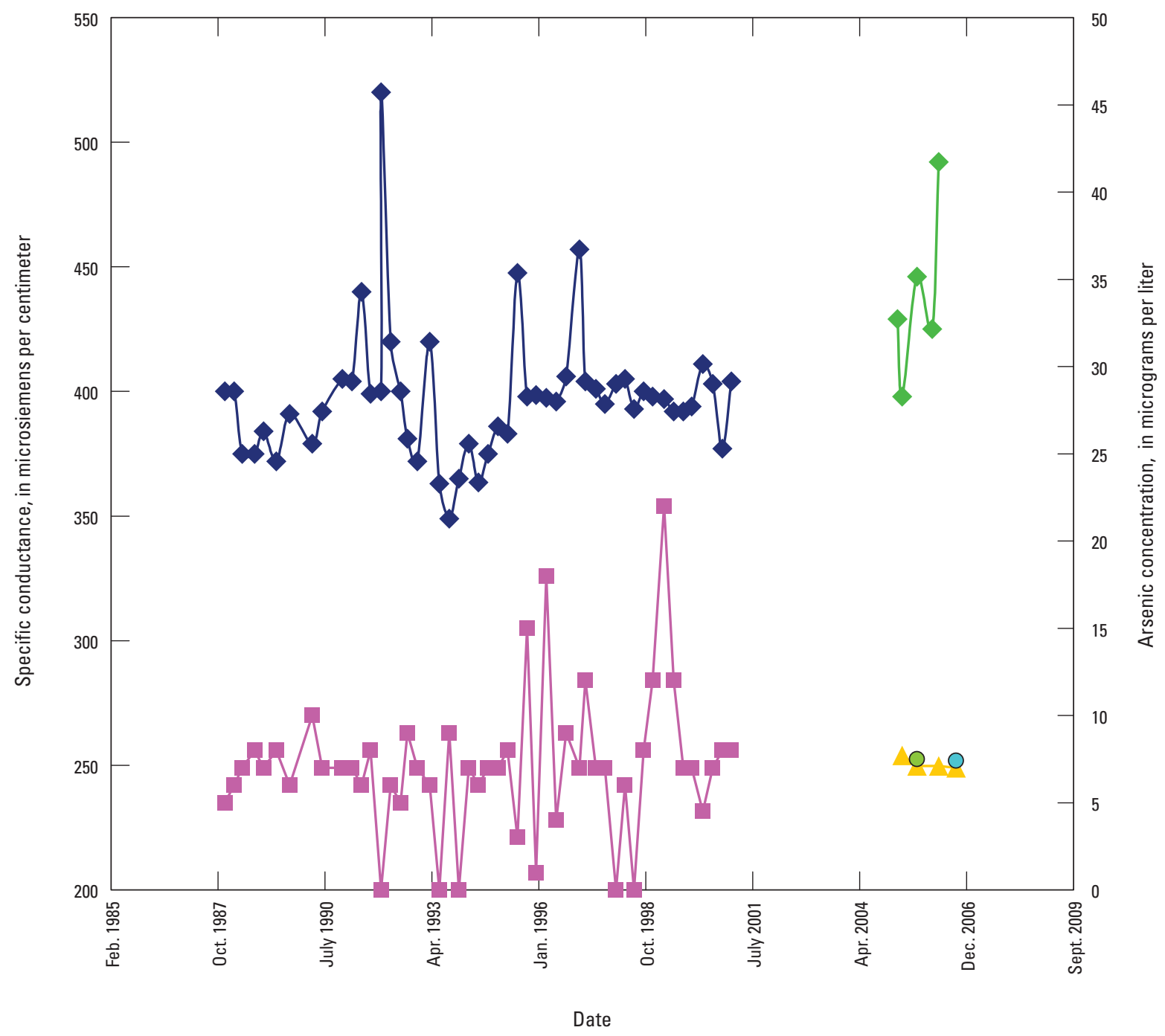

EXPLANATION

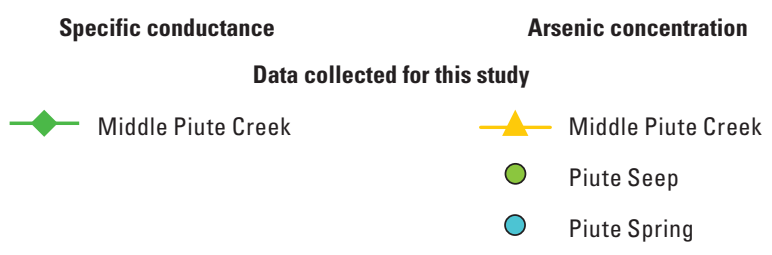

Data collected by Viceroy Gold Corporation

$\smile$ Piute Dam (destroyed) $\quad \longrightarrow$ Piute Dam (destroyed)

Figure 24. Specific conductance and arsenic concentrations for samples collected in the Piute Creek study area by Viceroy Gold Corporation, 1987-2000, and by the U.S. Geological Survey for this study, 2005-06, Mojave Network Parks, California. 
Table 14. Statistical summary of water-quality data for 51 samples collected from Piute Creek by Viceroy Gold Corporation between December 1987 and December 2000, and data from one sample collected by the U.S. Geological Survey (USGS) September 2, 1981, Mojave Network Parks, California.

[Calculations based on data in appendix 4; 1987-2000 data from M.E. Kazelskis, Project Geologist, Broadbent and Associates, Inc., written commun., 2001; samples collected about 6 meters (20 feet) downstream from the Piute Dam (near Lower Piute Creek; fig. 11); CV, coefficient of variation (in percent) equals standard deviation divided by mean; $\mu \mathrm{S} / \mathrm{cm}$ at $25^{\circ} \mathrm{C}$, microsiemens per centimeter at 25 degrees Celsius; $\mathrm{mg} / \mathrm{L}$, milligrams per liter; $\mathrm{CaCO}_{3}$, calcium carbonate; $\mathrm{SiO}_{2}$, silicon dioxide; $\mu \mathrm{g} / \mathrm{L}$, micrograms per liter]

\begin{tabular}{lcccccc}
\hline \multicolumn{1}{c}{ Constituent, concentration unit } & Maximum & Minimum & Median & Mean & $\begin{array}{c}\text { CV } \\
\text { (in percent) }\end{array}$ & USGS $^{1}$ \\
\hline Specific conductance, $\mu \mathrm{S} / \mathrm{cm}$ at $25^{\circ} \mathrm{C}$ & 520 & 349 & 397.5 & 397.3 & 6.7 & 460 \\
Dissolved solids, $\mathrm{mg} / \mathrm{L}$ & 387.5 & 155 & 272 & 274.9 & 14.4 & 325 \\
$\mathrm{pH}$, standard units & 8.69 & 7.00 & 7.89 & 7.86 & 4.3 & 8.25 \\
Alkalinity, $\mathrm{mg} / \mathrm{L}$ as $\mathrm{CaCO}_{3}$ & 242.5 & 85.7 & 153 & 159.7 & 17.5 & 190 \\
Calcium, $\mathrm{mg} / \mathrm{L}$ & 44.0 & 22.0 & 28.0 & 28.3 & 12.3 & 37 \\
Magnesium, $\mathrm{mg} / \mathrm{L}$ & 17.0 & 12.0 & 14.0 & 14.0 & 8.1 & 16 \\
Potassium, $\mathrm{mg} / \mathrm{L}$ & 18.2 & 5.12 & 6.22 & 6.66 & 18.3 & 6.4 \\
Sodium, $\mathrm{mg} / \mathrm{L}$ & 43.2 & 24.8 & 32.4 & 32.4 & 10.7 & 35 \\
Chloride, $\mathrm{mg} / \mathrm{L}$ & 25.6 & 0.43 & 17.6 & 17.9 & 19.6 & 21 \\
Fluoride, $\mathrm{mg} / \mathrm{L}$ & 2.7 & 0.04 & 0.55 & 0.61 & 70.7 & 0.2 \\
Sulfate, $\mathrm{mg} / \mathrm{L}$ & 53.2 & 5.12 & 18.0 & 18.5 & 31.0 & 26 \\
Silica, $\mathrm{mg} / \mathrm{L}$ as $\mathrm{SiO} \mathrm{F}_{2}$ & 84.4 & 29.4 & 62.7 & 61.2 & 20.5 & 67 \\
${ }^{2} \mathrm{Nitrate}, \mathrm{mg} / \mathrm{L}$ as nitrogen & 1.05 & 0.36 & 0.59 & 0.55 & 37.1 & 0.39 \\
${ }^{3}$ Arsenic, $\mu \mathrm{g} / \mathrm{L}$ & 22 & 1 & 7 & 7.8 & 44.7 & 8 \\
\hline
\end{tabular}

${ }^{1}$ Sample collected September 2, 1981, by U.S. Geological Survey from Piute Creek at concrete dam.

${ }^{2}$ Nitrate concentrations in samples collected in July 2, 1991 (209 mg/L), and September 25, 1996 (21.25 mg/L), were excluded in calculating the statistical summary because the high nitrate concentrations were considered to be extreme outliers.

${ }^{3}$ Values below the detection limit were replaced with the detection limit in calculating the statistical summary.

from Piute Seep in 2005 and was $27.5^{\circ} \mathrm{C}$ based on a single sample collected from Piute Spring in 2006 (fig. 11; table 8; method described in "Noble Gases" section of appendix 1). Recharge temperature calculated using the $\mathrm{N}_{2}$-Ar gas pair (Heaton and Vogel, 1981) averaged $22.8^{\circ} \mathrm{C}$ (ranged from 22.0 to $23.7^{\circ} \mathrm{C}$ ) for three samples from Piute Seep and was $27.0^{\circ} \mathrm{C}$ for a single sample from Piute Spring collected in September 2006 (fig. 11; table 7; method described in "Common Atmospheric Gases" section of appendix 1). The cooler recharge temperatures calculated using the noble gas data for Piute Seep (fig. 11) indicate that the recharge to the seep is not local recharge but rather recharge at higher altitudes in the drainage basin, which supports the higher altitude of recharge calculated from the stable isotope data. The calculated recharge temperature for Piute Spring is higher than expected for recharge occurring on the flanks of the New York Mountains (fig. 7) indicating that some stripping of gases might have occurred before or during sampling itself from these sites.

A single sample from Piute Spring (fig. 7) yielded a calculated ${ }^{14} \mathrm{C}$ age of 12,233 years, which was corrected to 6,825 years after using $\delta^{13} \mathrm{C}=-8.30$ per mil (table 6 ) in a two-member mixing model (Mazor, 1991), as described in the "Radioactive Isotopes" section of appendix 1, to correct for aqueous exchange with carbon containing no ${ }^{14} \mathrm{C}$ in the aquifer. Two samples from Piute Seep (fig. 11) that were collected after the summer 2005 flood yielded calculated ${ }^{14} \mathrm{C}$ ages of 7,148 and 8,166 years, which were corrected to 4,362 and 5,473 years, respectively, after the exchange with aquifer carbonate was accounted for. The $\delta^{13} \mathrm{C}$ values are 2 per mil more negative at Piute Seep than at Piute Spring (table 6), which lies farther up the canyon (fig. 11) implying discharge from Piute Spring has had less interaction with aquifer carbonates.

\section{Fortynine Palms Oasis, Joshua Tree National Park}

Three USGS monitoring sites were established in the Fortynine Palms Oasis study area in the Joshua Tree National Park to evaluate the hydrogeology and water quality of the riparian habitat of the Fortynine Palms Oasis: Upper Pool, Middle Pool, and Lower Pool (fig. 16). The sites were monitored for discharge, air temperature, water temperature, and (or) water quality depending on the conditions and location of the site (table 1; fig. 16). 


\section{Discharge}

The spring at Fortynine Palms Oasis (fig. 12) discharges beneath a large pool, which is referred to as the Upper Pool in this report (fig. 16). A ridge of soil and large boulders separates the Upper Pool into a larger eastern and smaller western basin. During the summer of 2005, a flood caused both basins to be enlarged and deepened. Several water level marks (stains) on the boulders adjacent to the Upper Pool (fig. 16) indicate past floods. Water discharges from the northern end of the eastern basin and continues flowing downstream in a succession of small waterfalls and pools that overflow and fall into one another, and extend about $76 \mathrm{~m}$ downstream from the Upper Pool (fig. 16) before finally infiltrating beneath the channel. Water discharges from the northwestern end of the smaller western basin and flows about $9 \mathrm{~m}$ before it infiltrates beneath the surface. Total discharge of the spring was determined by adding discharge measurements from both the eastern and western basins of the Upper Pool (fig. 16).

Three discharge measurements at the Upper Pool (fig. 16) ranged from $0.01 \mathrm{ft}^{3} / \mathrm{s}(5.4 \mathrm{gal} / \mathrm{min})$ in September 2005 to less than $0.01 \mathrm{ft}^{3} / \mathrm{s}(0.37 \mathrm{gal} / \mathrm{min})$ in September 2006 (table 2) when the water level was so low that surface discharge occurred from only one of the two basins. Modified PRISM annual precipitation also decreased from 2005 to 2006 (fig. 25) indicating that both discharge and precipitation decreased between the first and second year of the study (fig. 18C).

Fortynine Palms Oasis (fig. 12) is maintained almost solely by subsurface inflow with only very brief inflow of surface water from the drainage basin to the Upper Pool (fig. 16) during precipitation events. The residence time of water in the Upper Pool (fig. 16) was estimated by dividing the volume of the pool by the measured discharge from the pool. The volume of the Upper Pool (34 cubic meters [ $\left.\mathrm{m}^{3}\right]$; fig. 16) was estimated by multiplying the area of the pond (about 34 square meters $\left[\mathrm{m}^{2}\right]$ ) by the mean depth of the pool $(1 \mathrm{~m})$. The minimum estimated residence time was about 1 day on September 28,2005 , when discharge was $5.4 \mathrm{gal} / \mathrm{min}\left(0.01 \mathrm{ft}^{3} / \mathrm{s}\right)$, and the maximum estimated residence time was about 17 days on September 27, 2006, when discharge was $0.37 \mathrm{gal} / \mathrm{min}$ $\left(<0.01 \mathrm{ft}^{3} / \mathrm{s}\right)$.

\section{Temperature}

Water-temperature probes were installed at the Upper Pool and Lower Pool, and an air-temperature probe was installed at the Upper Pool in May 2005 (fig. 16). A flood at Fortynine Palms Oasis (fig. 12) on July 24, 2005, destroyed the water-temperature probes before any data could be downloaded, and debris from the flood buried the air-temperature probe. The air-temperature data collected after the flood was affected by being buried by debris from the flood and was not stored in NWIS. Replacement water-temperature probes were installed in September 2005.
Air temperatures between September 2005 and September 2006 ranged from 7.3 to $36.2^{\circ} \mathrm{C}$, whereas water temperatures ranged from 11.7 to $28.1{ }^{\circ} \mathrm{C}$ in the Upper Pool and from 6.5 to $28.4^{\circ} \mathrm{C}$ in the Lower Pool (figs. 16 and 26). Water temperature in both the Upper and the Lower Pool (fig. 16) responded quickly to changes in air temperature and indicated seasonal fluctuations (fig. 26). Mazor (1991) reported that seasonal variations in temperatures of springs indicate rapid flow through high-conductive rocks or conduits. The seasonal variations in discharge and temperature (fig. 26) measured in the Upper Pool (fig. 16) indicate rapid flow through rocks or conduits with high hydraulic conductivity, such as fractures in the underlying granitic rock. Measurements collected by lowering water-temperature probes to the bottom of the Upper Pool (fig. 16) failed to reveal any spatial heterogeneity in temperature that could identify the exact location of the spring discharge. Fiber optic distributed temperature sensors placed on the bottom of the pool could be used to help identify the location of the spring discharge (Lane, 2007).

\section{Water Quality}

The dissolved-solids concentration (DSC; measured as ROE in table 3 ) had a mean of $334 \mathrm{mg} / \mathrm{L}$ in four samples collected from the Upper Pool (fig. 16), which is higher than expected, considering the granitic rocks in the drainage basin (fig. 13) and the short subsurface residence time of groundwater discharge to Fortynine Palms Oasis (less than or equal to 2 years) as described in the "Altitude, Temperature, and Age of Recharge" section of the report. Rivers and shallow groundwater are commonly saline in arid or semiarid regions as a result of evaporation (Mazor, 1991). Evaporation causes the salts in precipitation to concentrate in the soil in arid or semiarid regions, and they are partially washed down with precipitation that infiltrates into the groundwater (Mazor, 1991). The DSCs were lower in 2005 (307-319 mg/L) when precipitation was high (about $360 \mathrm{~mm}$ ) compared to 2006 (347-361 mg/L) when precipitation was low (about $130 \mathrm{~mm}$; table 3; fig. 25). The DSCs were probably lower in 2005 than in 2006 (table 3) because the higher volumes of precipitation resulted in more infiltration, which diluted the concentration of evaporated salts in the soil.

Concentrations of uranium (U) are more than 15 times higher than measured at the other springs and ranged from 78.9 to $113 \mu \mathrm{g} / \mathrm{L}$ (table 5). These high concentrations of $\mathrm{U}$ are attributed to high U content of granitic rocks (Hem, 1989).

A single sample was collected in April 2006 for analysis of polar (water soluble) pesticides and a suite of more watersoluble pesticides from the Upper Pool (fig. 16; table 9). Although pesticides have not been used at this site, seasonal atmospheric transport from the Coachella Valley (fig. 1) and Imperial Valley (fig. 1) to the south, where pesticide use for agriculture is high, has been postulated. Pesticides were not detected above LRLs; however, fipronil and three of its degradates (Madsen and others, 2003) were reported, but at concentrations below the LRL. 

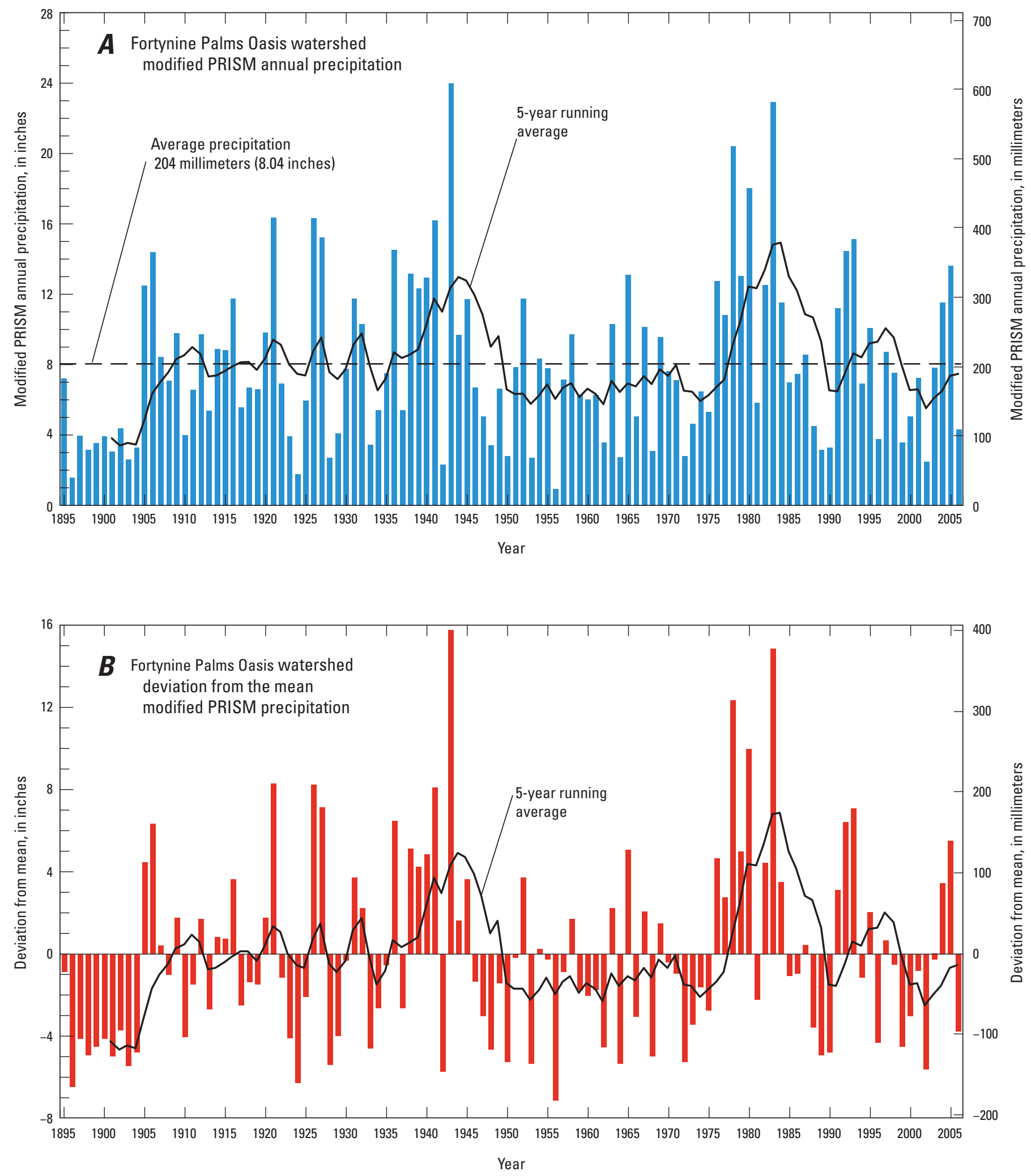

Figure 25. Modified Parameter Regression on Independent Slopes Model (PRISM) annual precipitation and deviation from the mean for Fortynine Palms Oasis drainage basin, Mojave Network Parks, 1895-2006. A, Annual precipitation. B, Deviation from the mean. 


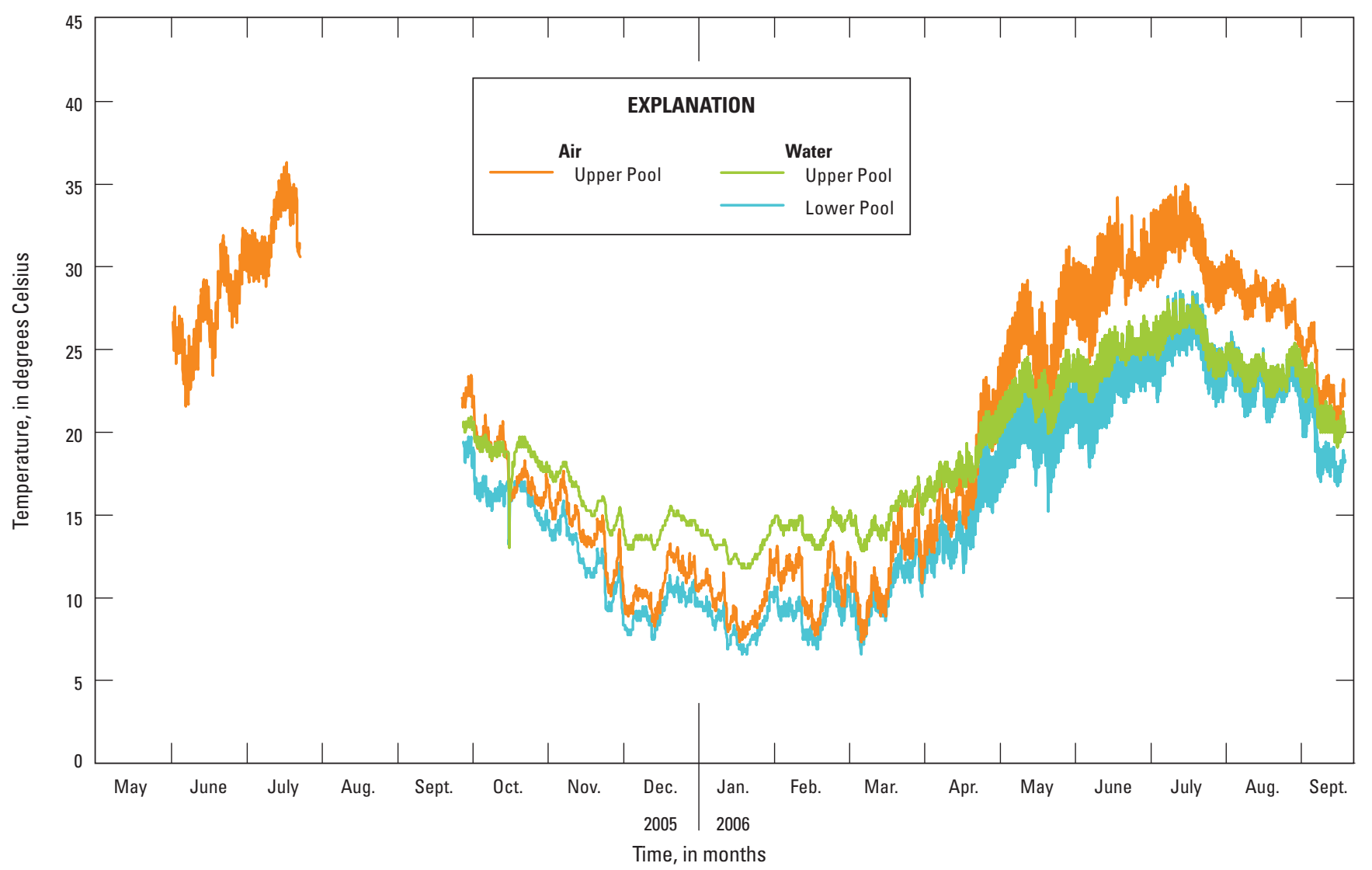

Figure 26. Air and water temperatures at Fortynine Palms 0asis study area, Mojave Network Parks, California, 2005-06.

\section{Altitude, Temperature, and Age of Recharge}

Water isotopes were used to estimate an average altitude of recharge to the Upper Pool (fig. 16) of the Fortynine Palms Oasis (fig. 12) by using equation 2 as described in the "Stable Isotopes" section of appendix 1 . The estimated average altitude of recharge to Upper Pool was 1,400 m (table 12), $542.6 \mathrm{~m}$ higher (table 12) than the altitude of the Upper Pool ( $857.4 \mathrm{~m}$; table 1; fig. 16), which is based on its mean $\delta \mathrm{D}$ of -77.2 per mil (table 6 ). The estimated average altitude of recharge for the Upper Pool (857.4 m; table 12; fig. 16) of the Fortynine Palms Oasis (fig. 12) implies that most of the recharge occurs near the summit of Queen Mountain (fig. 12).

Recharge temperature calculated by using noble gases (Heaton and Vogel, 1981; Aeschbach-Hertig and others, 1999; Aeschbach-Hertig and others, 2000; and Manning and Solomon, 2003) averaged $18.0^{\circ} \mathrm{C}$ for two samples collected from Fortynine Palms Oasis (fig. 12; table 8; method referenced in "Noble Gases" section of appendix 1) and was almost the same as the recharge temperature calculated by using the $\mathrm{N}_{2}$-Ar gas pair (Heaton and Vogel, 1981), which averaged $17.7^{\circ} \mathrm{C}$ (range is 16.6 to $18.7^{\circ} \mathrm{C}$ ) for four samples at the Upper Pool (table 7; method referenced in "Common Atmospheric Gases" section of appendix 1). The calculated recharge temperature was only a little cooler than the mean sample temperature of $19.5^{\circ} \mathrm{C}$ from the Fortynine Palms Oasis (fig. 12; table 2).

Three samples collected from the Upper Pool (fig. 16) at Fortynine Palms Oasis (fig. 12) had ${ }^{14} \mathrm{C}$ activities between 92.21 and $97.00 \mathrm{pmc}$, which translates to calculated ${ }^{14} \mathrm{C}$ ages ranging from 252 to 671 years; however, ${ }^{3} \mathrm{H}$ greater than $1 \mathrm{TU}$ (table 6) indicated that at least some of the water has recharged since 1950. Rapid water-rock interactions in the unsaturated and saturated zones cause the initial ${ }^{14} \mathrm{C}$ activities to drop as much as 60 percent in carbonate aquifers and 90 percent in silicate aquifers (Mazor, 1991). A likely explanation for these old radiocarbon ages is that infiltrating precipitation rapidly leached a mixture of modern and ${ }^{14} \mathrm{C}$-depleted carbon in the unsaturated and saturated zones.

Fortynine Palms Oasis (fig. 12) is the only one of the three study areas in which ${ }^{3} \mathrm{H}$ was detected, and its activity ranged from 1.24 to $2.49 \mathrm{TU}$ with a 1-sigma (1- $\sigma)$ precision of 0.09 to $0.13 \mathrm{TU}$ in five samples (table 6). These low activities indicate either recharge from precipitation over the last couple of years or a mixture of young and old water. Analyses of ${ }^{3} \mathrm{H}-{ }^{3} \mathrm{He}$ on two of the samples indicate an age estimate of less than or equal to 2 years (table 6), which is the limit of resolution. 


\section{Site Comparisons}

Discharge, temperature, water quality, water age, source of precipitation, recharge temperature, and climate measured or interpreted as part of this study were compared between the Darwin Falls, Piute Springs, and Fortynine Palms Oasis drainage basins. These site comparisons were used to find similarities and differences between the three drainage basins, which were used to help understand these unique environments.

\section{Discharge}

The springs monitored in the Darwin Falls (fig. 4), Piute Spring (fig. 7), and Fortynine Palms Oasis (fig. 12) drainage basins result from groundwater flowing from higher altitudes in the drainage basins to lower altitudes where shallowing, narrowing, or both, of the flow system forces groundwater to discharge to the surface. In Darwin and Piute Canyons (figs. 4 and 7), groundwater discharges through numerous springs and seeps to form a perennial stream; Darwin and Piute Springs (fig. 2 and 7) are the first (highest altitude) observed groundwater discharge in their respective canyons. At Fortynine Palms Oasis (fig. 12), the groundwater discharges only at the Upper Pool (fig. 16).

Discharge from springs is dependent on the balance between recharge and discharge in the drainage basin. The amount of recharge in a closed drainage basin is dependent on the size of the drainage basin and the amount of precipitation and runoff that infiltrates into the water table in the drainage basin. Under steady-state conditions (inflow equal to outflow), the amount of infiltrated precipitation will equal the amount of spring discharge if there is no other discharge from the drainage basin. Given a constant infiltration rate of precipitation over a drainage basin, the greater the size of the drainage basin, the greater the discharge rate of the spring.

The geologic and hydrological characteristics of the drainage basin and underlying groundwater basin control the amount of water that infiltrates from precipitation into the groundwater basin, and regulates the groundwater basin's capacity to store and transmit the infiltrated water. The groundwater basins in the Darwin Falls and Piute Spring drainage basins (figs. 2 and 7) consist predominately of alluvial deposits, whereas the groundwater basin in the Fortynine Palms Oasis drainage basin (fig. 12) consists predominately of fractured rock. An alluvial groundwater basin can store more water than a fractured-rock groundwater basin of equal size because of its greater porosity. Aquifers transmit water from recharge areas to discharge areas as a function of the hydraulic conductivity of the aquifer, as described in Darcy's law:

$$
Q=K A(d h / d l)
$$

where

$Q \quad$ is the quantity of water per unit of time;
$K \quad$ is the hydraulic conductivity and depends on the size and arrangement of the aquifers pores and fractures, the dynamic characteristics of the fluid, and the strength of the gravitational field;

$A \quad$ is the cross-sectional area of the aquifer perpendicular to the flow direction; and

$d h / d l \quad$ is the hydraulic gradient (Heath, 1983).

The hydraulic conductivity of a fracture can be much greater than the average hydraulic conductivity of an alluvial aquifer, but the overall hydraulic conductivity of a fracturedrock aquifer is generally much lower than an alluvial aquifer (Heath, 1983). The rate of movement of groundwater from recharge areas to discharge areas depends on the hydraulic conductivities of the aquifers and confining beds, if there is downward movement, and the hydraulic gradient. The time required for groundwater to move from a recharge area to the nearest discharge area ranges from a few days for adjacent recharge and discharge areas to thousands of years (millennia) for water to move from some recharge areas through the deeper parts of the groundwater system to some distant discharge area (Heath, 1983).

The Darwin Falls and Piute Spring drainage basins are more than 35 times larger than the Fortynine Palms Oasis drainage basin, so it is not surprising that discharge from both of them is much greater (table 2; figs. 2, 7, and 12). Also, because Darwin Falls and Piute Spring drainage basins (figs. 2 and 7) are alluvial groundwater basins with large amounts of groundwater storage, the natural discharge from these basins is relatively constant (figs. 19 and 22), as represented by streamflow discharge, and is not affected by recent precipitation in Darwin Wash and Piute Creek, respectively. However, because the Fortynine Palms Oasis drainage basin (fig. 12) is a fractured-rock system with a small amount of groundwater storage, the natural discharge (spring flow at the Upper Pool [fig. 16]) from this basin is highly variable and is closely related to recent precipitation (fig. 23). Evidence that this spring responds quickly is provided from seven measurements made during August and September between 1944 and 1952 when discharge ranged from as little as $0.03 \mathrm{gal} / \mathrm{min}$ $\left(<0.001 \mathrm{ft}^{3} / \mathrm{s}\right)$ to as much as $1.7 \mathrm{gal} / \mathrm{min}\left(0.004 \mathrm{ft}^{3} / \mathrm{s}\right)$ - a more than 50-fold difference (Weir and Bader, 1963).

The average altitude of recharge for Darwin Spring in the Darwin Falls drainage basin, Piute Spring in the Piute Spring drainage basin, and the Upper Pool in the Fortynine Palms Oasis drainage basin were 2,348 m, 1,668 m, and 1,400 $\mathrm{m}$; respectively (table 12). These average altitude of recharge values were estimated by using this study's $\delta \mathrm{D}$ values from the springs and published $\delta \mathrm{D}$ data from a historical precipitation network in California (Smith and others, 1992); the effect of altitude on $\delta \mathrm{D}$, as discussed in the "Stable Isotopes" section of appendix 1 and, previously, discussed in the sections on each study area (table 12). The area of the Darwin Falls drainage basin (fig. 2) that exceeds the estimated average recharge altitude of 2,348 m includes about $6.8 \mathrm{~km}^{2}$ in the Coso and Argus Ranges (fig. 2), which is about 1.5 percent of the total drainage 
basin. The area of the Piute Spring drainage basin (fig. 7) that exceeds the estimated average recharge altitude of 1,668 m includes about $19.8 \mathrm{~km}^{2}$ in the New York Mountains (fig. 7), which is about 3 percent of the total drainage basin. The area of the Fortynine Palms Oasis drainage basin that exceeds the estimated average recharge altitude of $1,400 \mathrm{~m}$ includes about $4.0 \mathrm{~km}^{2}$ in the Pinto Mountains (fig. 12), which is about 31 percent of the total drainage basin. Assuming all of the recharge originates in these areas, the distance from recharge to discharge is more than $16 \mathrm{~km}$ in the Darwin Falls drainage basin (fig. 2), more than $30 \mathrm{~km}$ in the Piute Spring drainage basin (fig. 7), and less than $5 \mathrm{~km}$ in the Fortynine Palms Oasis drainage basin (fig. 12). Because the Darwin Falls and Piute Spring drainage basins (figs. 2 and 7) have longer recharge to discharge flowpaths, the age of the groundwater discharged at the downgradient springs would be expected to be older than groundwater discharged from the shorter flowpath at Fortynine Palms Oasis (fig. 12).

The water available for recharge for each study area was estimated by multiplying the area above the estimated average altitude of recharge for each drainage basin by the modified PRISM mean annual precipitation between 1895 and 2006 for the area. The area above the estimated average altitude of recharge is $6.8 \mathrm{~km}^{2}$ in the Darwin Falls drainage basin (fig. 2), $19.8 \mathrm{~km}^{2}$ in the Piute Spring drainage basin (fig. 7), and $4 \mathrm{~km}^{2}$ in the Fortynine Palms Oasis drainage basin (fig. 12). The modified PRISM mean annual precipitation is 255 millimeters $(\mathrm{mm})$ for the Darwin Falls drainage basin, $256 \mathrm{~mm}$ for the Piute Spring drainage basin, and $237 \mathrm{~mm}$ for the Fortynine Palms Oasis drainage basin. The estimated annual water available for recharge is $1,734,000$ cubic meters per year $\left(\mathrm{m}^{3} / \mathrm{yr}\right.$; $870 \mathrm{gal} / \mathrm{min}$ ) for the Darwin Falls drainage basin; 5,068,800 $\mathrm{m}^{3} / \mathrm{yr}(2,540 \mathrm{gal} / \mathrm{min})$ for the Piute Spring drainage basin; and $948,000 \mathrm{~m}^{3} / \mathrm{yr}(475 \mathrm{gal} / \mathrm{min})$ for the Forytnine Palms Oasis drainage basin. These estimated annual recharge volumes could be less than actual values because only the area above the estimated average altitude of recharge was used in the estimation. Even so, these estimated values far exceed discharge actually measured during this study (table 2), which range from about 10 times higher in Darwin Wash to more than 200 times higher at the Upper Pool (fig. 16) of the Fortynine Palms Oasis (fig. 12). This difference is probably because only a fraction of the precipitation that falls above the estimated average altitude of recharge becomes recharge because of surface runoff and evapotranspiration in the immediate aftermath of rainfall events (Flint and others, 2013).

Any consumptive use of groundwater in the area of the drainage basin above the springs has the potential of decreasing discharge from the spring to the riparian habitat. Although consumptive use of water for mining activities above the springs occurred historically in both the Darwin Falls and Piute Spring drainage basins (figs. 2 and 7), mining no longer occurs in the three drainage basins. Darwin Falls drainage basin is the only one of the three study areas where a small amount of streamflow is withdrawn (streamflow is diverted from Darwin Wash downstream of the USGS gaging station; fig. 2) for commercial use at the Panamint Springs Resort (fig. 2), but the amount is likely to remain no more than a few percent of the total discharge of Darwin Wash (fig. 2). The Upper Pool (fig. 16) at Fortynine Palms Oasis (fig. 12) is the only one of the three springs that is near an area facing substantial demands on groundwater development accompanying an increasing population; however, groundwater withdrawal occurs on the desert floor and has little to no effect on the spring's discharge because the spring and associated drainage basin lie at a much higher altitude. Water-level altitudes in the Morongo Groundwater Basin (fig. 12) during 2008 ranged from $740 \mathrm{~m}$ above sea level in Indian Cove (fig. 12) northwest of the Upper Pool to $572 \mathrm{~m}$ above sea level in Twentynine Palms (fig. 1) north of the Upper Pool (fig. 16; Stamos and others, 2009), which is more than $115 \mathrm{~m}$ below the altitude of the Upper Pool at Fortynine Palms Oasis itself ( $857.4 \mathrm{~m}$ above sea level). The large difference in water-level altitudes over a relatively short distance indicates that there is little, if any, hydraulic connection between the spring and the aquifer that is located in the desert floor.

\section{Temperature}

Surface-water temperature measured at the three study areas followed the sinusoidal diurnal and seasonal patterns of air temperature, although the amplitude (range) was reduced to varying extents at each site (figs. 20, 23, and 26). In general, the range was less where measurement sites were close to an area of groundwater discharge (spring or seep), and the range was greater at sites downstream from the point of groundwater discharge where the length of time that water is exposed at or near land surface is increased. Seasonal differences of about $20{ }^{\circ} \mathrm{C}$ were measured at Darwin Wash downstream near the end of the riparian reach at the Darwin Falls study area (figs. 2 and 20).

Water temperatures measured at China Garden Spring and Darwin Spring in the Darwin Falls study area (figs. 2 and 20) were relatively constant (less than $2^{\circ} \mathrm{C}$ variation; table 2 ). Water temperature was only measured one time at Piute Spring (fig. 7; table 2), so temperature variation could not be determined. Water temperatures measured at the Upper Pool (fig. 16) in the Fortynine Palms Oasis (fig. 12) study area varied by about $15^{\circ} \mathrm{C}$ between winter and summer, and closely followed measured air temperatures (fig. 26). Temperature records of springs that correlate with seasonal air temperatures indicate a conduit type of recharge with short flow paths, whereas springs with constant temperatures indicate recharge through a porous medium with a long flow path (Mazor, 1991).

\section{Water Quality}

Water-quality measurements, including field measurements and salinity, major ions, nutrients, trace elements, and pesticides were compared for each of the study areas. Graphs 
and tables were prepared to help compare selected chemical constituents at the different study areas. Annual, and spring and summer differences in selected chemical constituents were compared to help determine if differences in precipitation were associated with changes in the chemical constituents.

\section{Field Measurements and Salinity}

Water samples from all three study areas contained DO ranging from $0.9 \mathrm{mg} / \mathrm{L}$ at Darwin Spring during 2005 to 9.0 $\mathrm{mg} / \mathrm{L}$ at Darwin Falls during 2006 (table 2). It is likely that aeration on exposure to the atmosphere caused increases in DO of surface water downstream from the springs at the Darwin and Piute study areas (table 2).

Measurements of EC and DSC were used in this study as indicators of salinity. Annual, and spring and summer differences in EC and DSC were compared to help determine if differences in precipitation were associated with changes in salinity (table 15). Recognizing that 2 years is a short period of monitoring, abnormally high rainfall during the 2004-05 winter, followed by an abnormally low rainfall the following winter (fig. 18), afforded the opportunity to measure salinity

Table 15. Annual, and spring and summer differences in specific conductance and dissolved-solids concentrations (reported as residue on evaporation) collected at the Darwin Falls, Piute Spring, and Fortynine Palms Oasis study areas, Mojave Network Parks, California, 2005-06.

[See figures 6, 11, and 16 for site locations and tables 2 and 3 for data; positive values indicate higher salinity [specific conductance or residue on evaporation (ROE)] in 2006 than in 2005 and higher salinity in summer than in winter; ROE, residue on evaporation at 180 degrees Celsius; spring, April 1-June 30; summer, July 1-September 30]

\begin{tabular}{|c|c|c|c|c|c|}
\hline \multirow{2}{*}{$\begin{array}{l}\text { Study } \\
\text { area }\end{array}$} & \multirow{2}{*}{$\begin{array}{l}\text { Report } \\
\text { site } \\
\text { name }\end{array}$} & \multicolumn{2}{|c|}{$\begin{array}{c}\text { Change between } \\
2005 \text { and } 2006, \\
\text { in percent }\end{array}$} & \multicolumn{2}{|c|}{$\begin{array}{l}\text { Change between } \\
\text { spring and summer, } \\
\text { in percent }\end{array}$} \\
\hline & & $\begin{array}{c}\text { Specific } \\
\text { conductance }\end{array}$ & ROE & $\begin{array}{c}\text { Specific } \\
\text { conductance }\end{array}$ & ROE \\
\hline $\begin{array}{c}\text { Darwin } \\
\text { Falls }\end{array}$ & $\begin{array}{l}\text { Darwin } \\
\text { Spring }\end{array}$ & 0.2 & -1.2 & -1.7 & $\left({ }^{1}\right)$ \\
\hline $\begin{array}{r}\text { Darwin } \\
\text { Falls }\end{array}$ & $\begin{array}{r}\text { Darwin } \\
\text { Falls }\end{array}$ & -4.1 & -3.1 & 2.2 & 4.9 \\
\hline $\begin{array}{l}\text { Piute } \\
\text { Spring }\end{array}$ & $\begin{array}{l}\text { Middle } \\
\text { Piute } \\
\text { Creek }\end{array}$ & 6.3 & 4.3 & 14 & 8.9 \\
\hline $\begin{array}{l}\text { Piute } \\
\text { Spring }\end{array}$ & $\begin{array}{l}\text { Piute } \\
\text { Seep }\end{array}$ & -5.4 & $\left(^{2}\right)$ & 5.0 & $\left({ }^{1}\right)$ \\
\hline $\begin{array}{l}\text { Fortynine } \\
\text { Palms } \\
\text { Oasis }\end{array}$ & $\begin{array}{l}\text { Upper } \\
\text { Pool }\end{array}$ & 10.8 & 13 & 1.5 & 0.2 \\
\hline
\end{tabular}

${ }^{1}$ Samples were not analyzed for spring 2005 and spring 2006.

${ }^{2}$ Samples were not analyzed for 2006. under both conditions. Measurements of EC were made during spring and late summer in 2005 and 2006 at Darwin Spring, Darwin Falls, Piute Seep, Middle Piute Creek, and the Upper Pool at Fortynine Palms Oasis (table 2; fig. 27). Dissolvedsolids concentrations (reported as ROE) were analyzed on samples from the same sites, with the exception that DSCs were not analyzed on the samples collected from Darwin Spring (fig. 2) during the spring of 2005 and 2006, and were only analyzed on the late summer 2005 sample from Piute Seep (table 3; fig. 11). Measurements of EC collected at the sites in March 2005 were not included in the comparisons because measurements were not collected at all of the sites.

At the Darwin Falls study area (Darwin Springs and Darwin Falls; fig. 2), annual, and spring and summer differences in salinity were less than 5 percent (table 15). Differences were greater at Darwin Falls than at Darwin Springs (fig. 2), which would be expected because Darwin Falls is a mixture of groundwater discharge and surface-water runoff. Darwin Falls (fig. 2) had higher salinity in 2005 than in 2006 and higher salinity at the end of the summer than in spring. If dilution was the primary factor affecting differences in the observed salinity, the 2005 salinity should have been lower than the 2006 salinity because the simulated precipitation and measured flow were greater in 2005 than in 2006 (fig. 18A). The higher salinity in 2005 could be the result of dissolution of salts from the Pzs that surround Darwin Canyon (fig. 4). These rocks consist of sandstone, siltstone, limestone and conglomerate, shale, and calc-hornfels (Stone and others, 1998).

At the Piute Spring study area, Middle Piute Creek had higher salinity in 2006 than in 2005 and higher salinity at the end of the summer than in the spring (table 15; fig. 11). Middle Piute Creek (fig. 11) is a mixture of groundwater discharge and surface-water runoff; therefore, dilution from the higher runoff in 2005 compared to 2006 (and spring compared to summer) likely accounts for the observed differences in salinity. At Piute Seep (fig. 11) the salinity decreased about 5 percent between 2005 and 2006 and increased 5 percent between spring and summer (table 15). Relatively constant salinity, as observed at Piute Seep (fig. 11), is indicative of a single source of water to a spring (Mazor, 1991).

At the Fortynine Palms Oasis study area (Upper Pool; fig. 16), the salinity increased about 10 percent between 2005 and 2006, which is consistent with declining rainfall (table 15). However, differences between spring and summer salinity were negligible (table 15). As stated previously in this report, evaporation causes the salts in precipitation to concentrate in the soil in arid or semiarid regions, and they are partially washed down with precipitation that infiltrates into the groundwater (Mazor, 1991). The salinity was probably lower in 2005 than in 2006 because the higher volumes of precipitation resulted in more infiltration, which diluted the concentration of evaporated salts in the soil. This rapid response of the Upper Pool (fig. 16) to recent precipitation is supported by the young age of the water $\left({ }^{3} \mathrm{H}-{ }^{3} \mathrm{He}\right.$ age of water in the Upper Pool is not more than about 2 years; table 6). 


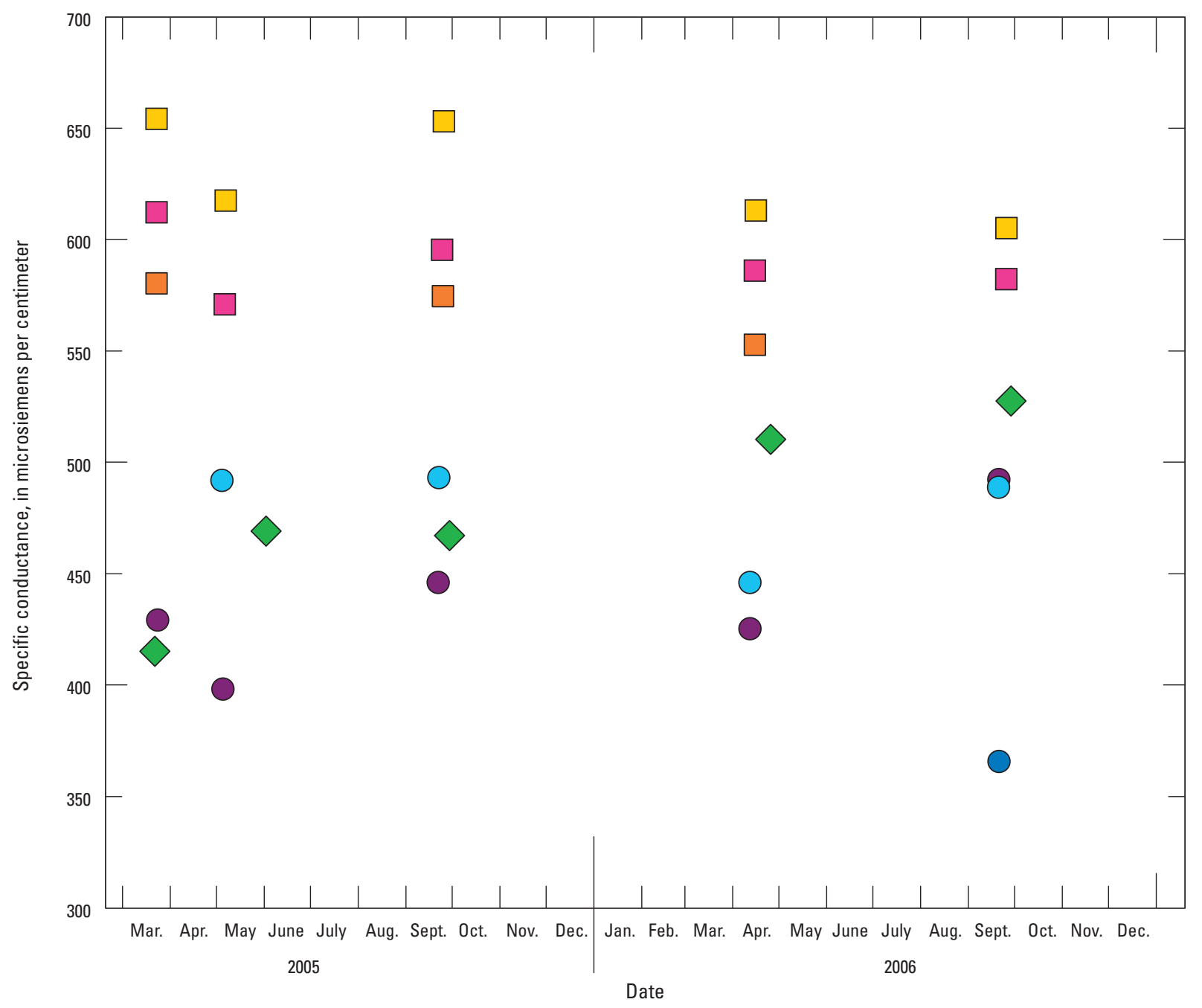

EXPLANATION

\begin{tabular}{|l}
\multicolumn{1}{c}{ Sample location } \\
$\square \quad$ China Garden Spring \\
$\square \quad$ Darwin Spring \\
$\square \quad$ Darwin Falls \\
$\quad$ Piute Spring \\
$\quad$ Middle Piute Creek \\
$\quad$ Piute Seep \\
$\triangle \quad$ Upper Pool
\end{tabular}

Figure 27. Specific conductance in samples collected at the Darwin Falls, Piute Spring, and Fortynine Palms Oasis study areas, Mojave Network Parks, California, 2005-06. 
Major lons

Dissolved ions are produced by the weathering (dissolution) of rocks as groundwater moves through the subsurface where it meets deposits of differing mineral composition that weather at different rates (Hem, 1989). Among the three study areas, salinity was highest at Darwin Falls (figs. 2 and 28), which probably is the result of dissolution of salts from the Pzs that surround Darwin Canyon (figs. 3 and 4). Salinity was slightly higher at Fortynine Palms Oasis than at Piute Spring (figs. 7, 12, and 28) despite much younger groundwater at Fortynine Palms Oasis compared to Piute Spring. Fortynine Palms Oasis (fig. 12) is an area dominated by Cretaceous-Jurassic granite (KJg) (fig. 13), whereas Piute Spring (fig. 7) is in an area dominated by Tertiary volcanic and sedimentary (Tvs) rocks (fig. 9). Surface water originating in areas dominated by igneous rocks, such as granite, is generally low in dissolved solids because the weathering of igneous rocks is slow (Hem, 1989). As stated previously, the salinity in the Fortynine Palms Oasis (figs. 12 and 28) samples probably is from the dissolution of salts left in the soil by the evaporation of precipitation in arid to semiarid regions. Piute Spring (fig. 7) also is in an arid to semiarid region; however, the stable isotopes indicate that the spring is recharged at a higher altitude than Fortynine Palms Oasis (table 14; fig. 12), which could help explain the slightly lower salinity (fig. 28). Precipitation is greater in the recharge area of Piute Spring (fig. 7; average of $256 \mathrm{~mm}$ ) than in the recharge area of Fortynine Palms Oasis (fig. 12; average of $237 \mathrm{~mm}$ ), and evaporation would be lower at the higher altitude of recharge (Flint and Flint, 2007b). The combination of more precipitation and less evaporation could result in less salt buildup in the soil in the Piute Spring recharge area (fig. 7).

Differences in the relative abundance of different cations and anions among the three study areas were slight as indicated by a Piper diagram (Piper,1944) and constituent concentrations (fig. 29; table 3). Because the relative proportion of major ions remained virtually unchanged in successive samples from each site, it is likely that groundwater flow travels through the same geologic units despite the differences in discharge that were measured during the course of this study (table 2). Although major-ion composition is not an especially sensitive metric, this conclusion is reinforced by the absence of change in Sr-isotope ratios in successive samples from all three study areas (table 6). The dissolution exchange of $\mathrm{Sr}$ between solid and aqueous phases is fairly rapid, so groundwater commonly acquires a $\mathrm{Sr}$ isotopic signature that matches the deposit or geologic unit with which it was most recently in contact (Turekian and Wedepohl, 1961).

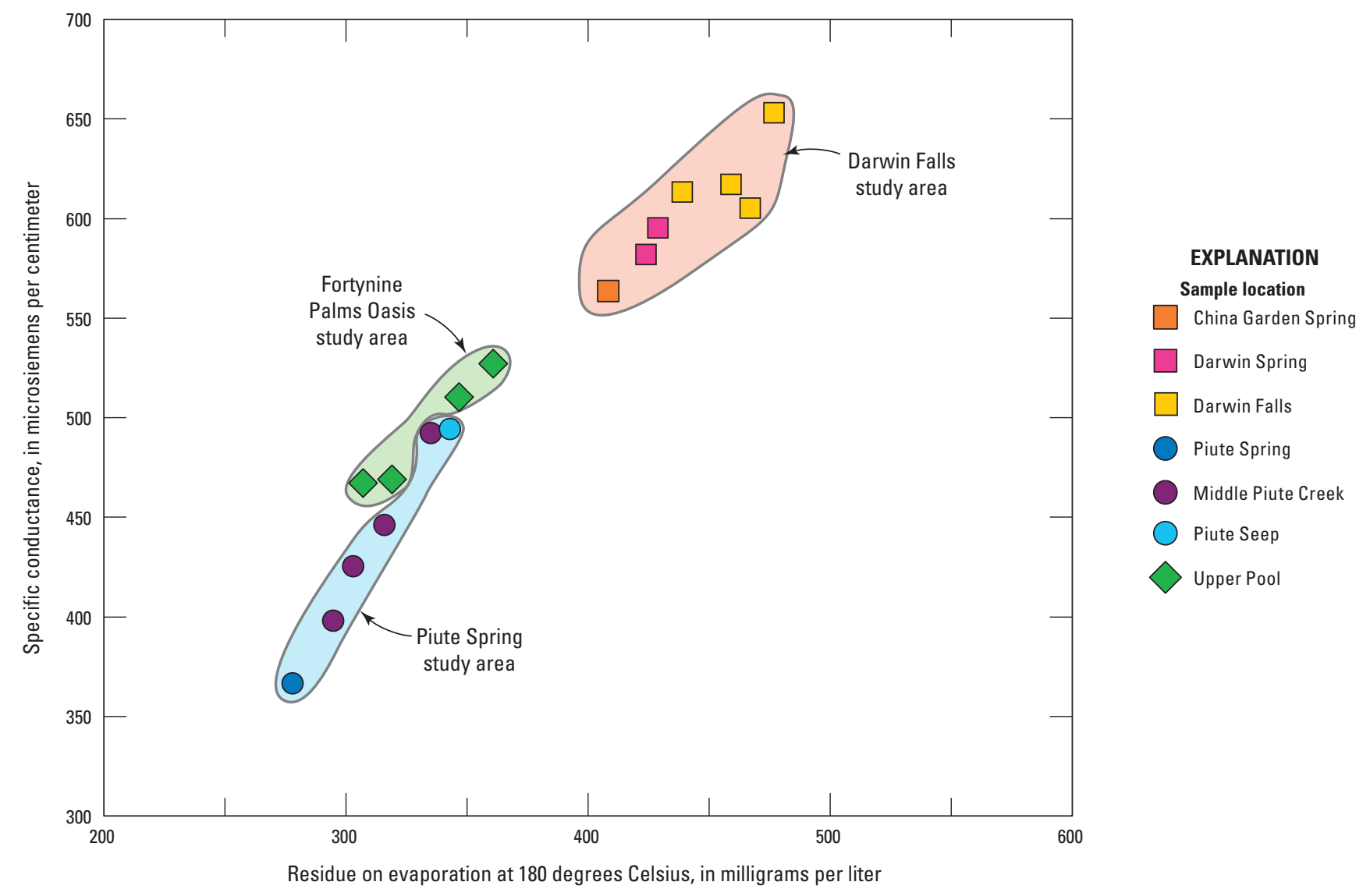

Figure 28. Relation between specific conductance and residue on evaporation (ROE) in samples collected at the Darwin Falls, Piute Spring, and Fortynine Palms Oasis study areas, Mojave Network Parks, California, 2005-06. 


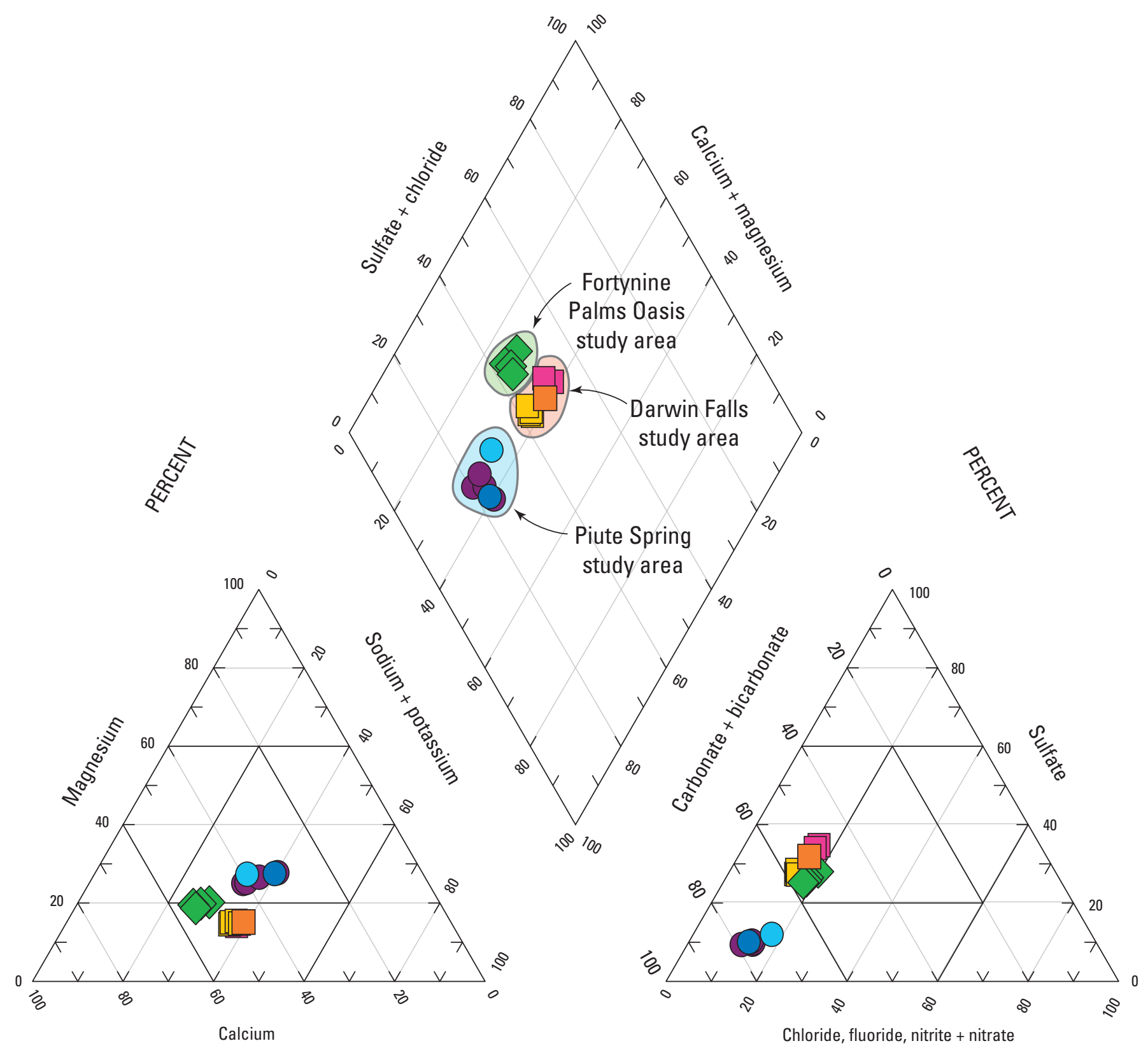

Percent, in milliequivalents per liter

\section{EXPLANATION}
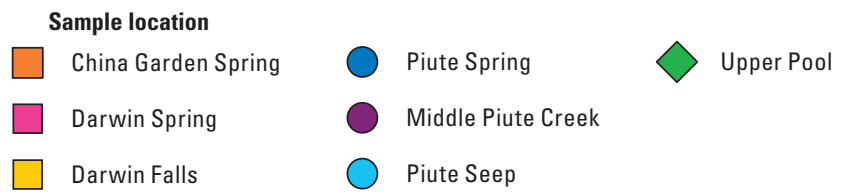

Figure 29. Major-ion composition in samples collected at the Darwin Falls, Piute Spring, and Fortynine Palms Oasis study areas, Mojave Network Parks, California, 2005-06. 
Dissolved $\mathrm{Ca}$ and $\mathrm{SiO}_{2}$ concentrations can be limited by the solubility of calcareous and siliceous minerals (Hem, 1989). The computerized geochemical model (PHREEQC; Parkhurst and Appelo, 1999) was used to compute saturation index (SI) values for three common Ca minerals (calcite, gypsum, and fluorite) and three forms of $\mathrm{SiO}_{2}$ (quartz, chalcedony, and amorphous silica) by comparing thermodynamic solubility values for these minerals to measured chemical concentrations in water (table 16). Calculated SI values generally are within about 0.1 of one another for sites where analyses from multiple sampling trips were available; mean values are listed in table 16. Positive SI values signify that chemical concentrations exceed a mineral's solubility in the water sample indicating that, thermodynamically, the mineral would be expected to precipitate (Parkhurst and Appelo, 1999). Negative SI values signify that chemical concentrations are less than a mineral's solubility in the water sample indicating that, thermodynamically, the mineral would be expected to dissolve (Parkhurst and Appelo, 1999).

Calculated SI values (table 16) indicated that calcite was approximately in equilibrium, with respect to its solubility for the water samples from Darwin Spring and Piute Spring (figs. 2 and 7), and is the only mineral limiting dissolved $\mathrm{Ca}$ concentrations. However, it is noteworthy that aqueous concentrations were oversaturated with respect to calcite at Darwin Falls compared to the upgradient Darwin Spring sample (fig. 2). This dissimilarity likely reflects a transitory lag in reestablishment of equilibrium following the rapid loss of $\mathrm{CO}_{2}$ as groundwater discharges from the spring, flows downstream, and eventually reequilibrates with the lower level of $\mathrm{CO}_{2}$ that exists in the atmosphere compared to the

Table 16. Saturation indices calculated by using the computerized geochemical model, PHREEOC, for selected calcium and silica minerals in water samples collected at the Darwin Falls, Piute Spring, and Fortynine Palms Oasis study areas, Mojave Network Parks, California, 2005-06.

[See figures 6, 11, and 16 for site locations and table 3 for data]

\begin{tabular}{lrrrrr}
\hline \multirow{2}{*}{ Mineral } & \multicolumn{5}{c}{ Saturation indices } \\
\cline { 2 - 6 } & $\begin{array}{c}\text { Darwin } \\
\text { Spring }\end{array}$ & $\begin{array}{c}\text { Darwin } \\
\text { Falls }\end{array}$ & $\begin{array}{c}\text { Piute } \\
\text { Spring }\end{array}$ & $\begin{array}{r}\text { Piute } \\
\text { Creek }\end{array}$ & $\begin{array}{c}\text { Upper } \\
\text { Pool }\end{array}$ \\
\hline Calcite & 0.00 & 0.92 & 0.09 & 0.40 & -0.26 \\
Gypsum & -1.68 & -1.69 & -2.69 & -2.54 & -1.89 \\
Fluorite & -1.14 & -0.98 & -1.85 & -1.68 & -0.52 \\
Quartz & 1.04 & 1.18 & 0.95 & 1.02 & 0.88 \\
Chalcedony & 0.61 & 0.72 & 0.53 & 0.60 & 0.44 \\
Amorphous & -0.24 & -0.10 & -0.30 & -0.25 & -0.42 \\
$\quad$ silica & & & & & \\
\hline
\end{tabular}

subsurface; this results in an increase in $\mathrm{pH}$ and concomitant decrease in the solubility of $\mathrm{Ca}$. The $\mathrm{pH}$ was 1 unit higher at Darwin Falls than at Darwin Spring (table 2), and time for the newly emerged surface water to transit the falls is so short that equilibrium, with respect to calcite, is not likely to have been established at Darwin Falls (fig. 2).

Even with respect to chalcedony, $\mathrm{SiO}_{2}$ 's cryptocrystalline polymorph, $\mathrm{SiO}_{2}$ was supersaturated, with respect to highlycrystalline quartz (table 16). Given $\mathrm{SiO}_{2}$ 's slow rate of crystallization at low ambient temperatures, dissolved $\mathrm{SiO}_{2}$ concentrations approached equilibrium, with respect to the highly soluble amorphous form, and some could be present as colloids that pass through the $0.45-\mu \mathrm{m}$ filter.

Marine salts carried with precipitation are a potential source of the major dissolved anions except for (carbonate) alkalinity, which is produced locally by the weathering (dissolution) of rocks. Evidence for this marine contribution can be quantified by comparing anion ratios in the ocean to these same ratios in the study areas (Davis and others, 1998). The halides, $\mathrm{Cl}$ and $\mathrm{Br}$, are very soluble and, therefore, could be expected to originate from marine salts in precipitation without further differentiation (preferential accumulation in the drainage basin) in water samples from the study areas. The finding that the $\mathrm{Cl} / \mathrm{Br}$ mass ratios are all close to 200 demonstrates the physically and chemically conservative behavior for both halides in all 3 drainage basins (fig. 30), and that the principal source of halides in these drainage basins is accumulation of marine salts from precipitation rather than internal sources (rocks) in the drainage basin. The slightly higher ratio in the samples from the Darwin Falls study area (fig. 30) could indicate modest accumulation of $\mathrm{Cl}$ in this drainage basin, but also is consistent with a trend to higher $\mathrm{Cl} / \mathrm{Br}$ ratios as distance from the coast increases (Davis and others, 1998).

An analogous examination of $\mathrm{Cl}$, relative to $\mathrm{SO}_{4}$ and $\mathrm{B}$, yielded a markedly different result (figs. 31 and 32 ). The dissolved $\mathrm{Cl} / \mathrm{SO}_{4}$ and $\mathrm{Cl} / \mathrm{B}$ mass ratios in the study areas were much less than their ratios of 7:1 and 4,300:1, respectively, in seawater - all data fall to the right of the seawater line (figs. 31 and 32). Further deviation from the seawater line corresponds to greater enrichment, or presence of $\mathrm{SO}_{4}$ and $\mathrm{B}$ deposits, within the drainage basin and subsequent leaching to the groundwater. Enrichment was generally greater (as much as five times) for $\mathrm{B}$ than for $\mathrm{SO}_{4}$, and was greatest for both elements in samples from the Darwin Falls study area (figs. 31 and 32); whereas $\mathrm{SO}_{4}$ is more enriched than $\mathrm{B}$ in samples from the Fortynine Palms Oasis (fig. 12) study area, and the reverse is true in samples from the Piute Spring study area (figs. 7, 31, and 32). Samples from Darwin Spring also tended toward greater enrichment for $\mathrm{SO}_{4}$, relative to samples from Darwin Falls (figs. 2 and 31), but the difference was small. This finding is consistent with earlier indications in this report that there could be multiple sources of groundwater discharged to the falls in Darwin Canyon (fig. 4). 


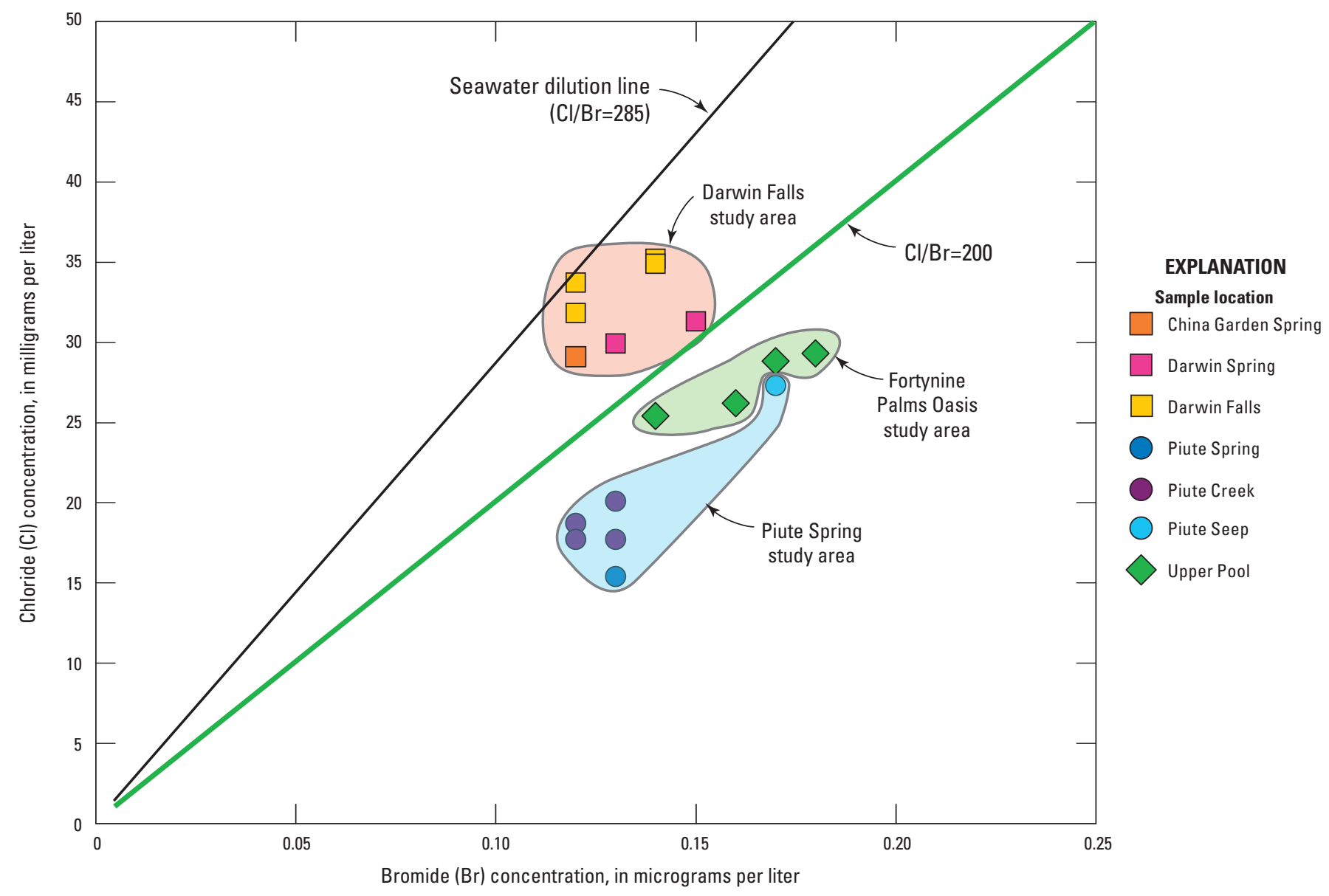

Figure 30. Chloride relative to bromide concentrations in samples collected at the Darwin Falls, Piute Spring, and Fortynine Palms Oasis study areas, Mojave Network Parks, California, 2005-06. 


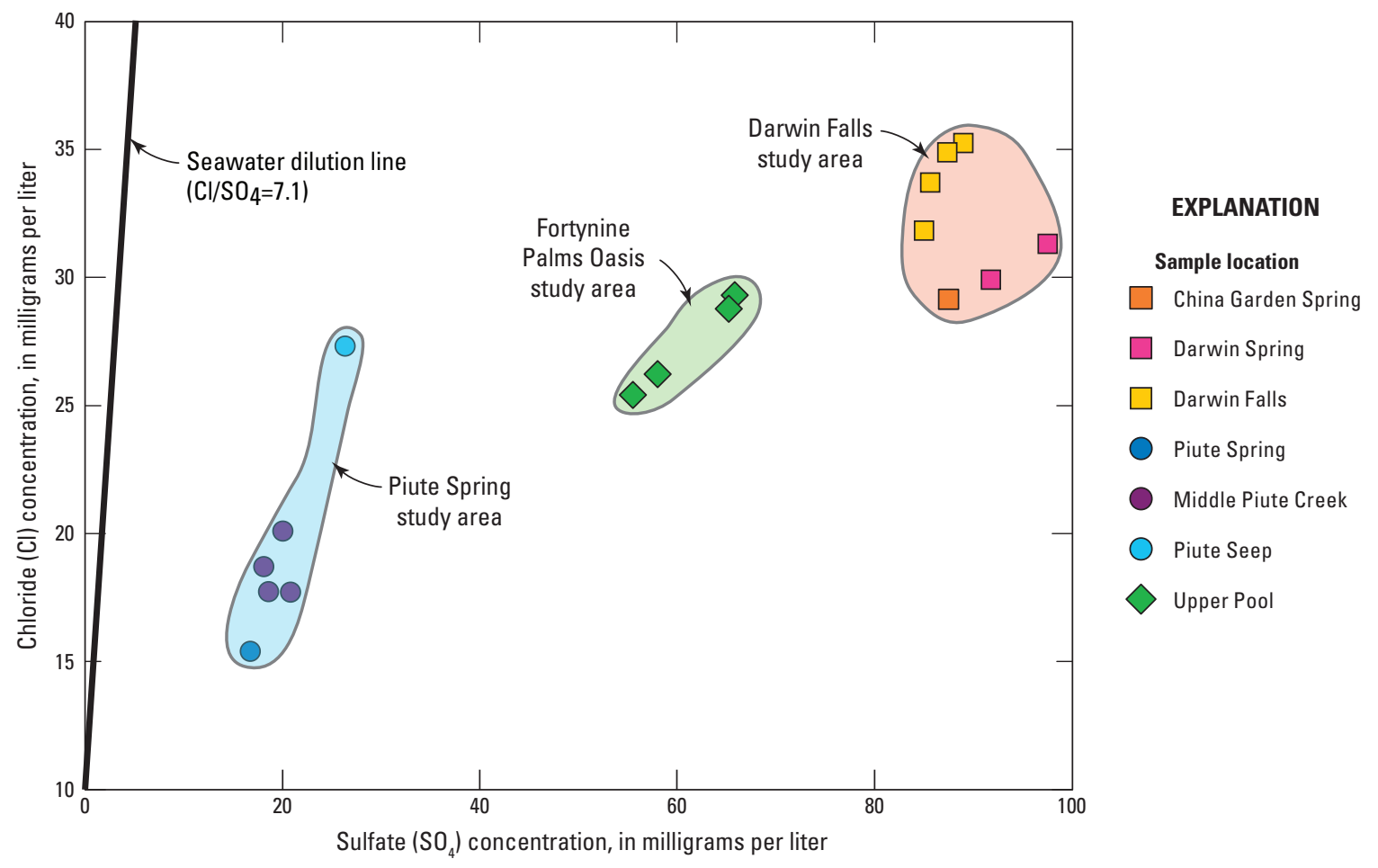

Figure 31. Chloride relative to sulfate concentrations in samples collected at the Darwin Falls, Piute Spring, and Fortynine Palms Oasis study areas, Mojave Network Parks, California, 2005-06.

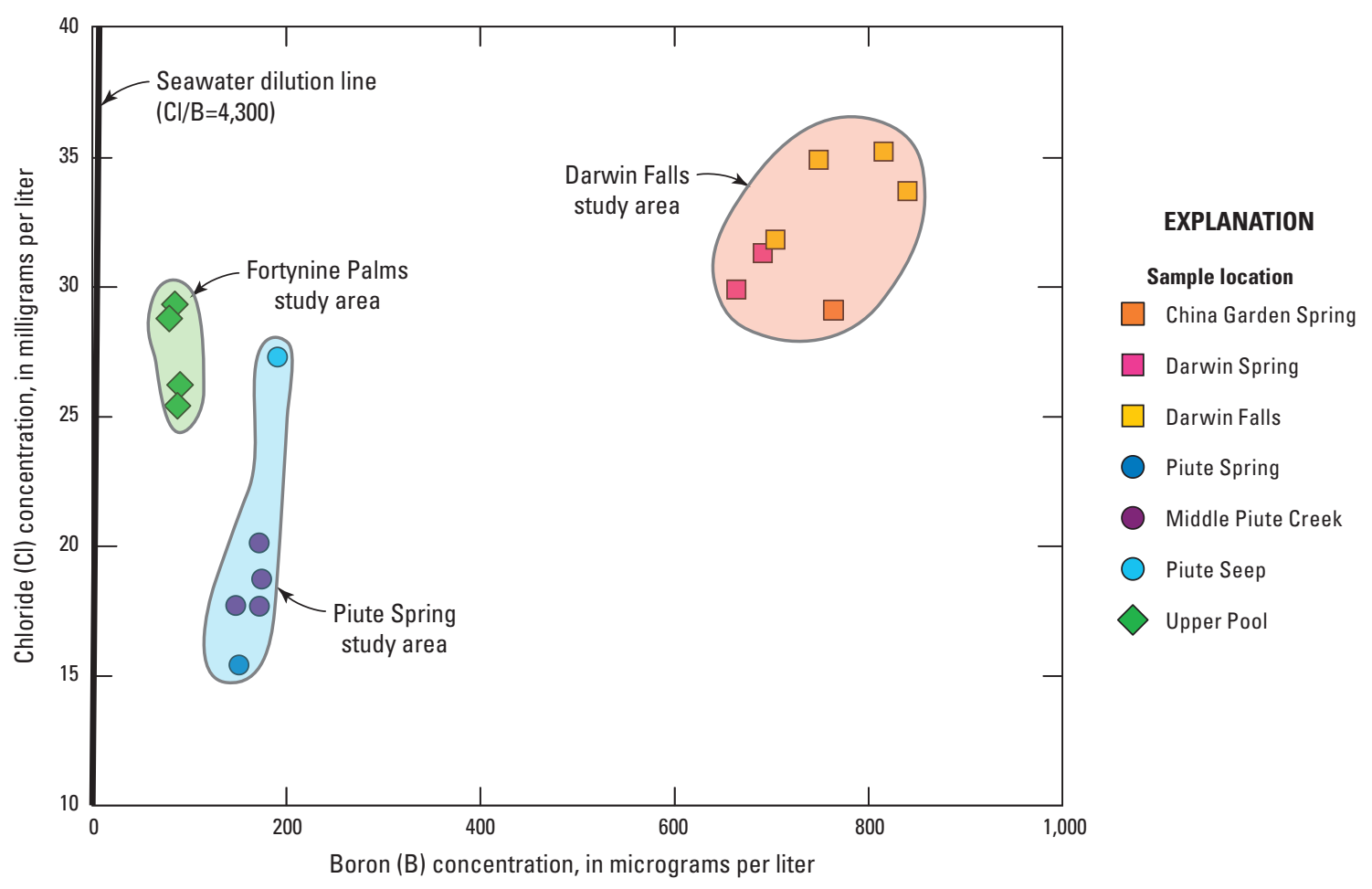

Figure 32. Chloride relative to boron concentrations in samples collected at the Darwin Falls, Piute Spring, and Fortynine Palms Oasis study areas, Mojave Network Parks, California, 2005-06. 
Nutrients

Concentrations of $\mathrm{N}$ and phosphorus $(\mathrm{P})$ were low at all sites (table 4). However, both nutrients are essential to supporting biota (Hem, 1989). Concentrations of $\mathrm{PO}_{4}-\mathrm{P}$ were determined to be very close to, or less than, the LRL of $0.02 \mathrm{mg} / \mathrm{L}$ in all samples from the three study sites (table 4). However, $\mathrm{N}$ concentrations were higher in samples from the Piute Spring (fig. 7) study area compared to samples from the other two study areas (table 4). About 99 percent of the $\mathrm{N}$ in Piute Creek (fig. 9) existed in the +5 state as $\mathrm{NO}_{3}$, and about 1 percent was present in the +3 state as $\mathrm{NO}_{2}$. Mean $\mathrm{NO}_{2}+\mathrm{NO}_{3}$ concentrations, as $\mathrm{N}$, were $2.5 \mathrm{mg} / \mathrm{L}$ in samples from Piute Creek compared to only $0.11 \mathrm{mg} / \mathrm{L}$ in samples from Darwin Falls (fig. 2) and $0.08 \mathrm{mg} / \mathrm{L}$ in Fortynine Palms Oasis (fig. 12; table 4). The $\mathrm{N}$ concentrations could be lower in samples from the Darwin Falls and Fortynine Palms Oasis study areas (figs. 2 and 12) compared to samples from the Piute Spring study area (fig. 7; table 4) because the vegetation at these sites takes up the $\mathrm{NO}_{3}$, whereas fire and subsequent flood removed much of the vegetation in the Piute Spring study area. Stream nutrients, especially $\mathrm{NO}_{3}$, have been reported to increase for a few years following a wildfire in a drainage basin (Spencer and others, 2003; Mast and Clow, 2008). The experimental removal of vegetation in a forest in New Hampshire resulted in a distinct rise in $\mathrm{NO}_{3}$ concentrations in the water flowing from the drainage basin following the removal of vegetation (Borman and Likens, 1970). If the removal of vegetation by the wildfire and flood was the cause of the higher $\mathrm{NO}_{3}$ concentrations in the Piute Spring study area, aqueous $\mathrm{NO}_{3}$ concentrations should be lower when vegetation fully reestablishes itself in Piute Canyon in a few years (fig. 7). The $\mathrm{NO}_{3}-\mathrm{N}$ concentrations were less than about $1 \mathrm{mg} / \mathrm{L}(4.5 \mathrm{mg} / \mathrm{L}$ as $\mathrm{NO}_{3}$ ) in all but 2 of 51 samples collected in the study area for the Viceroy Gold Corporation between December 1987 and December 2000 (appendix 2) before the fire, which supports the explanation that the removal of vegetation was the cause for the higher $\mathrm{NO}_{3}$ concentrations in the Piute Spring study area (fig. 7).

\section{Trace Elements}

Concentrations of trace elements were low in all samples, except for As concentrations at Piute Spring and Darwin Falls study areas (figs. 2 and 7) and $U$ concentrations at Fortynine Palms Oasis study area (fig. 12; table 5). Concentrations of As were near the EPA drinking water MCL for As of $10 \mu \mathrm{g} / \mathrm{L}$ (U.S. Environmental Protection Agency, 2010) in samples from the Piute Spring study area (fig. 7) and above the MCL in samples from the Darwin Falls study area (fig. 2). The element As is present in minor minerals (Hem, 1989) and can be mobilized by mining activities. Historically, mining activities existed in both drainage basins but were discontinued before this study. Concentrations of As in Middle Piute Creek (fig. 11) ranged between 7.0 and $7.7 \mu \mathrm{g} / \mathrm{L}$ during 2005 and 2006, which is virtually the same as historical concentrations from monitoring between December 1987 and December
2000 (fig. 24; table 13). Concentrations of As ranged from $51.4 \mu \mathrm{g} / \mathrm{L}$ at Darwin Spring to $32.1 \mu \mathrm{g} / \mathrm{L}$ at Darwin Falls (table 5) from which water is diverted and conveyed by gravity flow through a pipe next to Darwin Wash for use at Panamint Springs Resort (fig. 2). This water is unsuitable for potable use insofar as it exceeds MCL for As concentrations. Natural weathering of minerals likely is the cause of As mobilization in each drainage basin as mining would mobilize additional trace elements. High $\mathrm{U}$ concentration (78.9 to $113 \mu \mathrm{g} / \mathrm{L}$, drinking water MCL level is $30 \mu \mathrm{g} / \mathrm{L}$ ) in the Upper Pool (fig. 16) at Fortynine Palms Oasis (fig. 12) results from the element's high abundance in the granitic rocks from this drainage basin.

\section{Pesticides}

Pesticides were analyzed in selected samples from the Upper Pool (fig. 16) at Fortynine Palms Oasis (fig. 12) and Middle Piute Creek (fig. 11; table 9). A sample was collected from the Upper Pool (fig. 16) to evaluate if atmospheric transport from agricultural areas in the Coachella Valley to the south (fig. 1) affects the water quality at the spring. A sample was collected at Piute Creek (fig. 9) because herbicide use was reported by NPS to control salt cedar. Pesticides were not detected above LRLs in the samples collected at the end of the 2006 wet season. However, fipronil and three of its degradates (Madsen and others, 2003) were detected at concentrations below the LRL at Fortynine Palms Oasis (fig. 12). Caffeine, which is part of the pesticide analysis, was detected at both sites. Additional samples would be needed to verify the presence of fipronil and caffeine.

\section{Water Age}

Water sampled from Darwin and Piute Springs (figs. 2 and 7) had corrected ${ }^{14} \mathrm{C}$ ages ranging from 2,899 to 6,825 years, whereas water sampled from the Upper Pool (fig. 16) at Fortynine Palms Oasis (fig. 12) had a ${ }^{3} \mathrm{H}-{ }^{3} \mathrm{He}$ age of no more than about 2 years (table 6). Because water discharged at Darwin and Piute Springs is thousands of years old (figs. 2 and 7), changes in climate in the recharge areas of the springs are likely to take much longer to affect the discharge and water quality of these springs than at Fortynine Palms Oasis (fig. 12) where the spring discharge is much younger. Although the riparian habitat in all three study areas is potentially susceptible to human effects such as foot traffic, affects from human disturbance elsewhere within the drainage basin where recharge occurs will take decades to a millennia to be observed in the discharge, and water quality at Darwin Falls and Piute Spring study areas (figs. 2 and 7) because of the great length of time for recharge water $(2,899$ to 6,825 years; table 6) to reach the springs. Climatic or human induced changes to recharge would affect the discharge to the springs sooner than the water quality because the change in recharge would result in a pressure response to the aquifer system, which would travel through the aquifer system faster than a water molecule and associated solute. However, in large 
drainage basins, such as Darwin Falls and Piute Spring (figs. 2 and 7 ), there is a large time lag between changing the stress in a recharge and observing its effect on discharge at a distant spring (Bredehoeft and Durbin, 2009). Because of the great time lag, it could be desirable to institute protective measures in the recharge areas to ensure that potential changes to the quantity or quality of recharge water do not affect the discharge and water quality of these springs in the distant future.

\section{Source of Precipitation}

The stable-isotope ratios of water decrease (they become more negative, lighter, or depleted in the heavier isotope) as latitude and altitude increase (Dansgaard, 1964). The effect from latitude is generally much less than the effect from altitude in the Mojave Desert (fig. 1), although the response to latitude could be accentuated in this study because a large proportion of precipitation in the Piute Spring and Fortynine Palms Oasis study areas (figs. 7 and 12) is from storms that originate in the Gulf of Mexico and the subtropical North Pacific (Smith and others, 1992). The $\delta \mathrm{D}$ and $\delta^{18} \mathrm{O}$ values analyzed for this study were more negative at the Darwin Falls study area compared to the Piute Spring and Fortynine Palms Oasis study areas (figs. 7 and 12; table 6), and were consistent with the higher altitude and more northern latitude of the Darwin Falls study area (figs. 1 and 33).

The isotope data from all three study areas fall a little below the global meteoric water line (MWL; fig. 33), indicating possible evaporation at land surface before recharge, partial evaporation of falling raindrops in an arid atmosphere, or a "local" MWL that differs slightly from the global MWL (Mazor, 1991; see "Stable Isotopes" section of appendix 1). The regression equation $\delta \mathrm{D}=\delta^{18} \mathrm{O}+10$ was developed from coastal precipitation collected globally although most stations were in North America and Europe (Craig, 1961a). Many local data deviate slightly from the global MWL, and isotopic data collected seasonally and annually in precipitation from the southeastern California

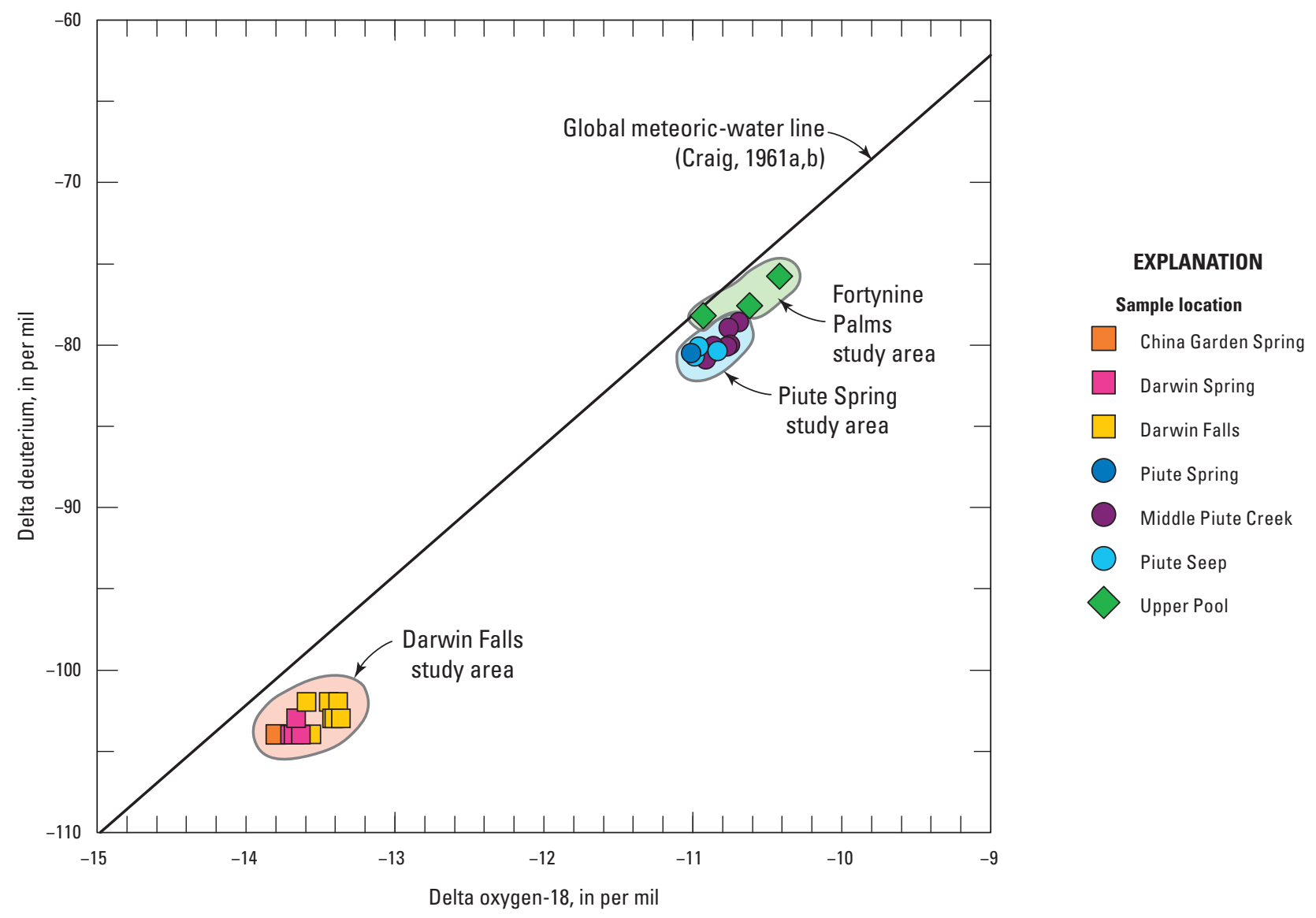

Figure 33. Relation between delta deuterium and delta oxygen-18 in samples collected at the Darwin Falls, Piute Spring, and Fortynine Palms Oasis study areas, Mojave Network Parks, California, 2005-06. 
(Friedman and others, 1992) demonstrate this clearly. Dansgaard (1964) interpreted deviation from the global MWL as a simple adjustment to the intercept ("d-parameter"), thereby defining a local line that is parallel to the global MWL. A local MWL that lies 4 per mil (on the $\delta \mathrm{D}$ axis) below the global MWL was determined from groundwater in Indian Wells Valley (Berenbrock and Schroeder, 1994), which is in the western part of the Mojave Desert (fig. 1). The isotope data collected for this study appear to fall along a line that is nearly parallel to, and only about 2 to 3 per mil below, the global MWL (fig. 33).

Comparison of the stable-isotope ratios of water among the three study areas indicates that samples from the Upper Pool (fig. 16) of the Fortynine Palms Oasis study area (fig. 12) had the greatest scatter among all the sites monitored (fig. 33); its water has a much shorter travel time and, therefore, reflects short-term variations in the isotopic composition of rainfall. Comparison among samples collected within the Darwin Falls and the Piute Spring study areas (figs. 2 and 7) indicates that scatter was less for samples from the Darwin Spring and Piute Seep than from Darwin Falls and Middle Piute Creek (figs. 2, 11, and 33) because Darwin Falls and Middle Piute Creek contain a mixture of groundwater discharge and surface-water runoff from upstream areas, the latter of which is subject to evaporation.

\section{Recharge Temperature}

Recharge temperatures calculated by using water-isotope and gas-concentration data (tables 7 and 8), as described in the "Altitude, Temperature, and Age of Recharge" sections of the "Hydrological Results and Discussion" and in appendix 1, were compared to recharge temperatures derived from the expected difference in mean annual temperature between the altitude of the spring and its recharge area (table 12) based on the atmospheric lapse rate (table 17). Typical atmospheric lapse rates are -5 to $-8{ }^{\circ} \mathrm{C}$ per $\mathrm{km}$ of altitude gain and average $-6{ }^{\circ} \mathrm{C}$ per $\mathrm{km}$ (Manning and Solomon, 2003). This average value was used to calculate the recharge temperatures based on the differences between calculated recharge altitudes and sample altitudes (table 17). The average value is adequate for this purpose because the comparison is used only as a general indicator of whether recharge temperatures derived from gas data are reliable; the need for changes in the method of sample collection for gases would be indicated if the results differed markedly.

The estimated recharge temperatures for the different springs were in agreement given the various assumptions made (see the "Noble Gases" section of appendix 1) and differences between methods (table 17). The estimated recharge temperatures are all cooler than the measured temperatures of the springs, which support the conclusion from the stable isotope data that the source of recharge to the springs was not local precipitation but rather precipitation infiltrating on the higher altitudes of the drainage basins (table 12).

\section{Climate}

Temperature and precipitation for the California part of the Mojave Desert (fig. 1) were extracted from the regional data developed by Flint and Flint (2007b) to evaluate differences among study areas, assess annual fluctuations, and ascertain trends in the climate between 1895 and 2006 (figs. 34 and 35).

In the California part of the Mojave Desert (fig. 1), BCM-simulated maximum and minimum annual temperatures indicate an increasing trend beginning in the late 1970s with the greatest increase for minimum temperatures (fig. 34).

Table 17. Recharge temperatures calculated using the average atmospheric lapse rate and gas-concentration data on selected water samples collected at the Darwin Falls, Piute Spring, and Fortynine Palms Oasis study areas, Mojave Network Parks, California, 2005-06.

[See figures 6, 11, and 16 for site locations and tables 7, 8, and 12 for data; ${ }^{\circ} \mathrm{C}$, degrees Celsius; $\mathrm{m}$, meters; $\mathrm{N}_{2}$, nitrogen gas; $\mathrm{Ar}$, argon]

\begin{tabular}{|c|c|c|c|c|c|c|c|}
\hline \multirow{2}{*}{$\begin{array}{l}\text { Report } \\
\text { site } \\
\text { name }\end{array}$} & \multirow{2}{*}{$\begin{array}{l}\text { Measured water } \\
\text { temperature } \\
\text { in }{ }^{\circ} \mathrm{C}\end{array}$} & \multirow{2}{*}{$\begin{array}{l}\text { Altitude } \\
\text { of } \\
\text { sample } \\
\text { (m) }\end{array}$} & \multirow{2}{*}{$\begin{array}{l}\text { Calculated } \\
\text { altitude of } \\
\text { recharge } \\
\text { (m) }\end{array}$} & \multirow{2}{*}{$\begin{array}{l}\text { Calculated } \\
\text { altitude } \\
\text { difference } \\
\text { (m) }\end{array}$} & \multicolumn{3}{|c|}{ Calculated recharge temperature in ${ }^{\circ} \mathrm{C}$} \\
\hline & & & & & $\begin{array}{l}\text { Atmospheric } \\
\text { lapse rate }^{1}\end{array}$ & $\begin{array}{l}\text { Noble } \\
\text { gasses }\end{array}$ & $\mathrm{N}_{2}-\mathrm{Ar}$ \\
\hline Darwin Spring & 21.8 & 932.7 & 2,348 & $1,415.3$ & 13.3 & 16.2 & 14.6 \\
\hline Piute Spring & 27.6 & 901.6 & 1,668 & 766.4 & 23.0 & 27.5 & 27.0 \\
\hline Piute Seep & 25.1 & 878.7 & 1,663 & 784.3 & 20.4 & 23.6 & 22.8 \\
\hline
\end{tabular}

${ }^{1}$ Recharge temperature was calculated by multiplying the difference between the altitude of the sample and the calculated altitude of recharge by the average atmospheric lapse rate $\left(-6^{\circ} \mathrm{C}\right.$ per kilometer), and then subtracting this value from the measured water temperature at the sample site.

${ }^{2}$ Mean water temperature was $2.5^{\circ} \mathrm{C}$ higher in 2005 than in 2006 . 

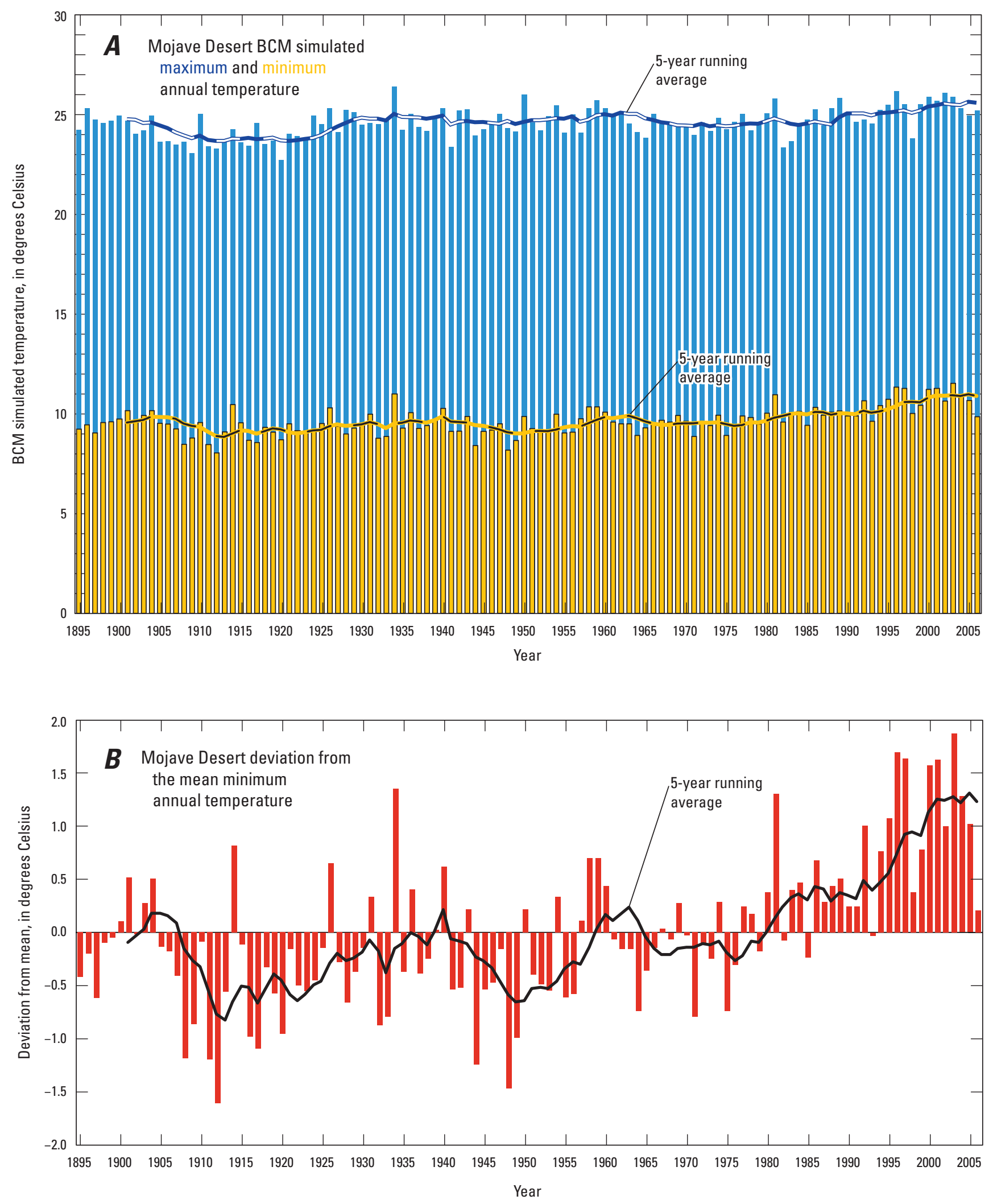

Figure 34. Basin characterization model (BCM) simulated maximum and minimum annual temperature and deviation from the mean minimum annual temperature in the California part of the Mojave Desert, 1895-2006. $A$, Maximum and minimum annual temperature. $B$, Deviation from the mean minimum annual temperature. 

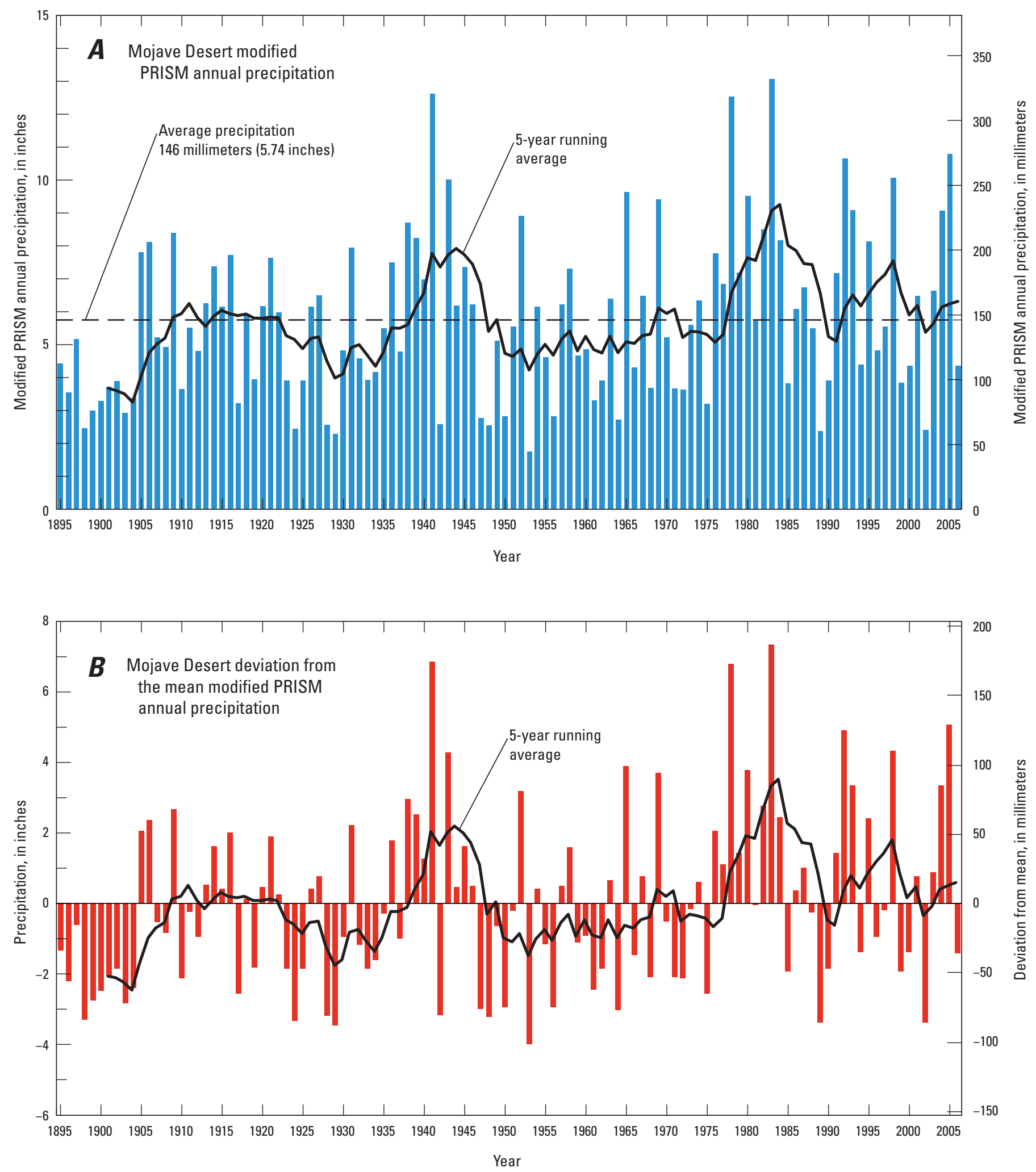

Figure 35. Modified Parameter Regression on Independent Slopes Model (PRISM) annual precipitation and deviation from the mean in the California part of the Mojave Desert, 1895-2006. A, Annual precipitation. $B$, Deviation from the mean. 
The average modified PRISM annual precipitation for the California part of the Mojave Desert (fig. 1) was $146 \mathrm{~mm}$, which is drier than the Darwin Falls (176.4 mm), Piute Spring $(198.5 \mathrm{~mm})$, and Fortynine Palms Oasis $(204 \mathrm{~mm})$ study areas (figs. 2, 7, 12, 17, 21, 25, and 35). Unlike the BCM simulated annual temperature, the modified PRISM annual precipitation did not indicate an increasing trend beginning in the late 1970s (fig. 35). Climate models are in general agreement that the air temperature will continue to increase by as much as $3{ }^{\circ} \mathrm{C}$ by 2100 in the southwestern United States in response to increases in greenhouse gases (Dettinger and Earman, 2007; Intergovernmental Panel on Climate Change, 2007), and they typically predict overall drying trends in the desert areas of the southwestern United States (Seager and others, 2007). Increased air temperature will increase rates of evaporation, and decrease streamflows by lowering contributions from runoff and groundwater sources. In addition, increased air temperature will increase the potential evapotranspiration, which likely will increase anthropogenic water demands and stress the limited water resources in this region. It would appear, based on the small changes in water quality that were observed during this study and some very limited historical water-quality data, that it is quantity rather than quality that likely will be of primary concern with respect to the future viability of desert springs to support riparian ecosystems. 


\section{Chapter C. Anuran Abundance and Health at Selected Springs in the Mojave Network Parks}

\author{
By Elizabeth Gallegos and Robert N. Fisher
}

Surveys for the western toad (Anaxyrus boreas) at Darwin Falls in Death Valley National Park, the red-spotted toad (Anaxyrus punctatus) at Piute Spring in Mojave National Preserve, and the red-spotted toad (Anaxyrus punctatus) and California treefrog (Pseudacris cadaverina) at Fortynine Palms Oasis in Joshua Tree National Park were conducted in the breeding season (spring and summer) from May to July of 2005 and April to July of 2006 (table 18; figs. 1, 2, 7, and 12). The objectives of these surveys were to document aquatic habitat and general biotic community, endemic anuran species present, their reproduction, and population sizes; and, to assess their overall health.

\section{Biological Methods}

The major biological methods used for this study included: (1) aquatic habitat and endemic anuran surveys, (2) documentation of the reproduction of endemic anurans, (3) determination of baseline population of endemic anurans, (4) evaluation of the general health of the endemic anuran, and (5) collection of voucher specimens of selected endemic anurans. These methods are briefly described in the following sections of the report and detailed descriptions of the methods are provided in documents referenced in the report.

\section{Aquatic Habitat and Endemic Anuran Surveys}

The available aquatic habitat and its associated endemic anuran biota were surveyed for each study area along selected reaches of the major stream channel in each study area (table 19; figs. 6, 11, and 16; appendix 3). Stream channels for each of the three study areas were mapped and divided into 250-meter $(\mathrm{m})$ and 125-m contiguous reaches.

Site-specific and survey-specific characteristics related to the aquatic habitat and general biotic community present were summarized for 250-m contiguous reaches in 2005 and for $125-\mathrm{m}$ contiguous reaches in 2006. The U.S. Geological Survey (USGS) Aquatic Species and Habitat Assessment Protocol (ASHAP; U.S. Geological Survey, 2006b) was used to document site-specific and survey-specific characteristics for each stream reach surveyed. Site-specific characteristics included geomorphological and landscape features such as slope, stream incision, channel and bank substrate, and permanency of water. Survey-specific characteristics included measures of water quality, hydrology, aquatic and streamside vegetative growth (including invasive exotic plants), presence of other aquatic species (including invasive exotic animals), and availability of aquatic refugia, basking areas, and pool habitats. In 2006, additional habitat data were collected every $125 \mathrm{~m}$ and included the following: basking areas present, percent overhead canopy above $1 \mathrm{~m}$, and percent vegetation in wetted reach. Over time, these measurements could be used as covariates in log-linear modeling and other analyses to determine predictive factors for species presence and probability of detection (MacKenzie and others, 2002). These metadata are not presented or discussed in this report, but were provided to the Death Valley National Park, the Mojave National Preserve, and the Joshua Tree National Park (fig. 1) for their archives.

In 2005, three nocturnal surveys of anuran species were conducted every $250 \mathrm{~m}$ for each site. In 2006, four nocturnal surveys were conducted every $125 \mathrm{~m}$ for each site. At the beginning of each survey, general weather conditions (air and water temperatures, cloud cover, and wind conditions) were recorded. Two people conducted these surveys using a Koehler wheat headlamp with 45,000-candle power. The surveys included recording or collecting Global Positioning System (GPS) coordinates, age class, sex (when possible), snout-vent length (SVL) in millimeters ( $\mathrm{mm}$ ), weight to the nearest gram (g), observations for abnormalities, and tissue samples (toe tip for future deoxyribonucleic acid [DNA] analysis) for all animals captured. Animals escaping capture were recorded as escaped, and their GPS coordinates were recorded. In 2006, 20 animals of each species were processed each sampling night. Processing consisted of obtaining all measurements mentioned above with the exception that tissue was collected from only 10 of the animals. All animals were released after capture.

\section{Reproduction}

Diurnal surveys were conducted to document species reproductivity. The presence and developmental stage of tadpoles in a system indicates timing of breeding within the system. Data on developmental stages (Gosner, 1960) of tadpoles were collected at each of the three surveys across all sites in 2006 (hereafter referred to as Gosner stages; fig. 36). The tadpoles observed were grouped into the following 3 Gosner stages of development: early (Gosner Stage 20-25), mid (Gosner Stages 26-42), and late (Gosner Stages 43-46; fig. 36). In addition, general weather conditions (air and water temperatures, cloud cover, and wind speed) were recorded. Global Positioning System (GPS) coordinates also were recorded for each animal capture. Handling was kept to an absolute minimum, and tadpoles were released at the location of capture. 


\section{Source, Discharge, and Chemical Characteristics of Selected Springs and Endemic Anuran Species, Mojave Network Parks}

Table 18. Summary of site locations, species of interest, and survey dates for the Darwin Falls, Piute Spring, and Fortynine Palms Oasis study areas, Mojave Network Parks, California, 2005-06.

$[-$, no data; $\mathrm{xx} / \mathrm{xx} / \mathrm{xxxx}$, month/day/year $]$

\begin{tabular}{|c|c|c|c|c|}
\hline $\begin{array}{l}\text { Park or } \\
\text { Preserve }\end{array}$ & $\begin{array}{l}\text { Study } \\
\text { area }\end{array}$ & $\begin{array}{l}\text { Species } \\
\text { of interest }\end{array}$ & $\begin{array}{c}\text { Days } \\
\text { surveyed }\end{array}$ & $\begin{array}{l}\text { Nights } \\
\text { surveyed }\end{array}$ \\
\hline Death Valley National Park & Darwin Falls & $\begin{array}{l}\text { Red-spotted toad (Anaxyrus punctatus) and } \\
\text { western toad (Anaxyrus boreas) }\end{array}$ & $05 / 11 / 2005$ & $05 / 11 / 2005$ \\
\hline Death Valley National Park & Darwin Falls & $\begin{array}{l}\text { Red-spotted toad (Anaxyrus punctatus) and } \\
\text { western toad (Anaxyrus boreas) }\end{array}$ & $06 / 09 / 2005$ & $06 / 08 / 2005$ \\
\hline Death Valley National Park & Darwin Falls & $\begin{array}{l}\text { Red-spotted toad (Anaxyrus punctatus) and } \\
\text { western toad (Anaxyrus boreas) }\end{array}$ & $07 / 08 / 2005$ & 07/07/2005 \\
\hline Death Valley National Park & Darwin Falls & $\begin{array}{l}\text { Red-spotted toad (Anaxyrus punctatus) and } \\
\text { western toad (Anaxyrus boreas) }\end{array}$ & $04 / 27 / 2006$ & $04 / 26 / 2006$ \\
\hline Death Valley National Park & Darwin Falls & $\begin{array}{l}\text { Red-spotted toad (Anaxyrus punctatus) and } \\
\text { western toad (Anaxyrus boreas) }\end{array}$ & $05 / 31 / 2006$ & $04 / 27 / 2006$ \\
\hline Death Valley National Park & Darwin Falls & $\begin{array}{l}\text { Red-spotted toad (Anaxyrus punctatus) and } \\
\text { western toad (Anaxyrus boreas) }\end{array}$ & $07 / 13 / 2006$ & $05 / 30 / 2006$ \\
\hline Mojave National Preserve & Piute Spring & Red-spotted toad (Anaxyrus punctatus) & $05 / 10 / 2005$ & $05 / 10 / 2005$ \\
\hline Mojave National Preserve & Piute Spring & Red-spotted toad (Anaxyrus punctatus) & $06 / 10 / 2005$ & $06 / 09 / 2005$ \\
\hline Mojave National Preserve & Piute Spring & Red-spotted toad (Anaxyrus punctatus) & $07 / 21 / 2005$ & $07 / 21 / 2005$ \\
\hline Mojave National Preserve & Piute Spring & Red-spotted toad (Anaxyrus punctatus) & ${ }^{1} 10 / 06 / 2005$ & $04 / 19 / 2006$ \\
\hline Mojave National Preserve & Piute Spring & Red-spotted toad (Anaxyrus punctatus) & $04 / 20 / 2006$ & $04 / 20 / 2006$ \\
\hline Mojave National Preserve & Piute Spring & Red-spotted toad (Anaxyrus punctatus) & $05 / 16 / 2006$ & $05 / 15 / 2006$ \\
\hline Mojave National Preserve & Piute Spring & Red-spotted toad (Anaxyrus punctatus) & $07 / 14 / 2006$ & $05 / 23 / 2006$ \\
\hline Joshua Tree National Park & Fortynine Palms Oasis & $\begin{array}{l}\text { Red-spotted toad (Anaxyrus punctatus) and } \\
\text { California treefrog (Pseudacris cadaverina) }\end{array}$ & $05 / 20 / 2005$ & $05 / 19 / 2005$ \\
\hline Joshua Tree National Park & Fortynine Palms Oasis & $\begin{array}{l}\text { Red-spotted toad (Anaxyrus punctatus) and } \\
\text { California treefrog (Pseudacris cadaverina) }\end{array}$ & $05 / 09 / 2006$ & $04 / 17 / 2006$ \\
\hline Joshua Tree National Park & Fortynine Palms Oasis & $\begin{array}{l}\text { Red-spotted toad (Anaxyrus punctatus) and } \\
\text { California treefrog (Pseudacris cadaverina) }\end{array}$ & $06 / 28 / 2006$ & $05 / 08 / 2006$ \\
\hline Joshua Tree National Park & Fortynine Palms Oasis & $\begin{array}{l}\text { Red-spotted toad (Anaxyrus punctatus) and } \\
\text { California treefrog (Pseudacris cadaverina) }\end{array}$ & - & $05 / 09 / 2006$ \\
\hline Joshua Tree National Park & Fortynine Palms Oasis & $\begin{array}{l}\text { Red-spotted toad (Anaxyrus punctatus) and } \\
\text { California treefrog (Pseudacris cadaverina) }\end{array}$ & - & $06 / 27 / 2006$ \\
\hline Joshua Tree National Park & Fortynine Palms Oasis & $\begin{array}{l}\text { Red-spotted toad (Anaxyrus punctatus) and } \\
\text { California treefrog (Pseudacris cadaverina) }\end{array}$ & - & $06 / 28 / 2006$ \\
\hline
\end{tabular}

\footnotetext{
${ }^{1}$ Habitat reconnaissance surveys conducted after a summer scouring event.
} 
Table 19. Location of biological surveys at Darwin Falls, Piute Spring, and Fortynine Palms Oasis study areas, Mojave Network Parks, California, 2005-06.

[Latitude and longitude are presented in degrees, minutes, seconds, referenced to the North American Datum of 1983 (NAD 83); Y, yes; N, no; km, kilometer]

\begin{tabular}{|c|c|c|c|c|c|c|c|c|}
\hline \multirow{2}{*}{$\begin{array}{l}\text { Park or } \\
\text { Preserve }\end{array}$} & \multirow{2}{*}{$\begin{array}{l}\text { Study } \\
\text { area }\end{array}$} & \multirow{2}{*}{$\begin{array}{l}\text { Species } \\
\text { of interest }\end{array}$} & \multirow{2}{*}{$\begin{array}{l}\text { Present } \\
\text { (Y/N) }\end{array}$} & \multicolumn{2}{|c|}{ Beginning } & \multicolumn{2}{|c|}{ End } & \multirow{2}{*}{$\begin{array}{l}\text { Total } \\
\text { length of } \\
\text { survey } \\
\text { (km) }\end{array}$} \\
\hline & & & & Latitude & Longitude & Latitude & Longitude & \\
\hline $\begin{array}{l}\text { Death Valley } \\
\text { National Park }\end{array}$ & Darwin Falls & $\begin{array}{c}\text { Red-spotted toad } \\
\text { (Anaxyrus punctatus) }\end{array}$ & $\mathrm{N}$ & $36^{\circ} 19^{\prime} 27^{\prime \prime}$ & $117^{\circ} 30^{\prime} 54^{\prime \prime}$ & $36^{\circ} 19^{\prime} 13^{\prime \prime}$ & $117^{\circ} 31^{\prime} 32^{\prime \prime}$ & 1.25 \\
\hline $\begin{array}{l}\text { Death Valley } \\
\text { National Park }\end{array}$ & Darwin Falls & $\begin{array}{c}\text { Western toad } \\
\text { (Anaxyrus boreas) }\end{array}$ & Y & $36^{\circ} 19^{\prime} 27^{\prime \prime}$ & $117^{\circ} 30^{\prime} 54^{\prime \prime}$ & $36^{\circ} 19^{\prime} 13^{\prime \prime}$ & $117^{\circ} 31^{\prime} 32^{\prime \prime}$ & 1.25 \\
\hline $\begin{array}{l}\text { Joshua Tree } \\
\text { National Park }\end{array}$ & $\begin{array}{l}\text { Fortynine } \\
\text { Palms Oasis }\end{array}$ & $\begin{array}{c}\text { Red-spotted toad } \\
\text { (Anaxyrus punctatus) }\end{array}$ & $\mathrm{Y}$ & $34^{\circ} 06^{\prime} 29^{\prime \prime}$ & $116^{\circ} 06^{\prime} 16^{\prime \prime}$ & $34^{\circ} 06^{\prime} 11^{\prime \prime}$ & $116^{\circ} 06^{\prime} 25^{\prime \prime}$ & 0.62 \\
\hline $\begin{array}{l}\text { Joshua Tree } \\
\text { National Park }\end{array}$ & $\begin{array}{c}\text { Fortynine } \\
\text { Palms Oasis }\end{array}$ & $\begin{array}{c}\text { California treefrog } \\
\text { (Pseudacris cadaverina) }\end{array}$ & $\mathrm{Y}$ & $34^{\circ} 06^{\prime} 29^{\prime \prime}$ & $116^{\circ} 06^{\prime} 16^{\prime \prime}$ & $34^{\circ} 06^{\prime} 11^{\prime \prime}$ & $116^{\circ} 06^{\prime} 25^{\prime \prime}$ & 0.62 \\
\hline
\end{tabular}



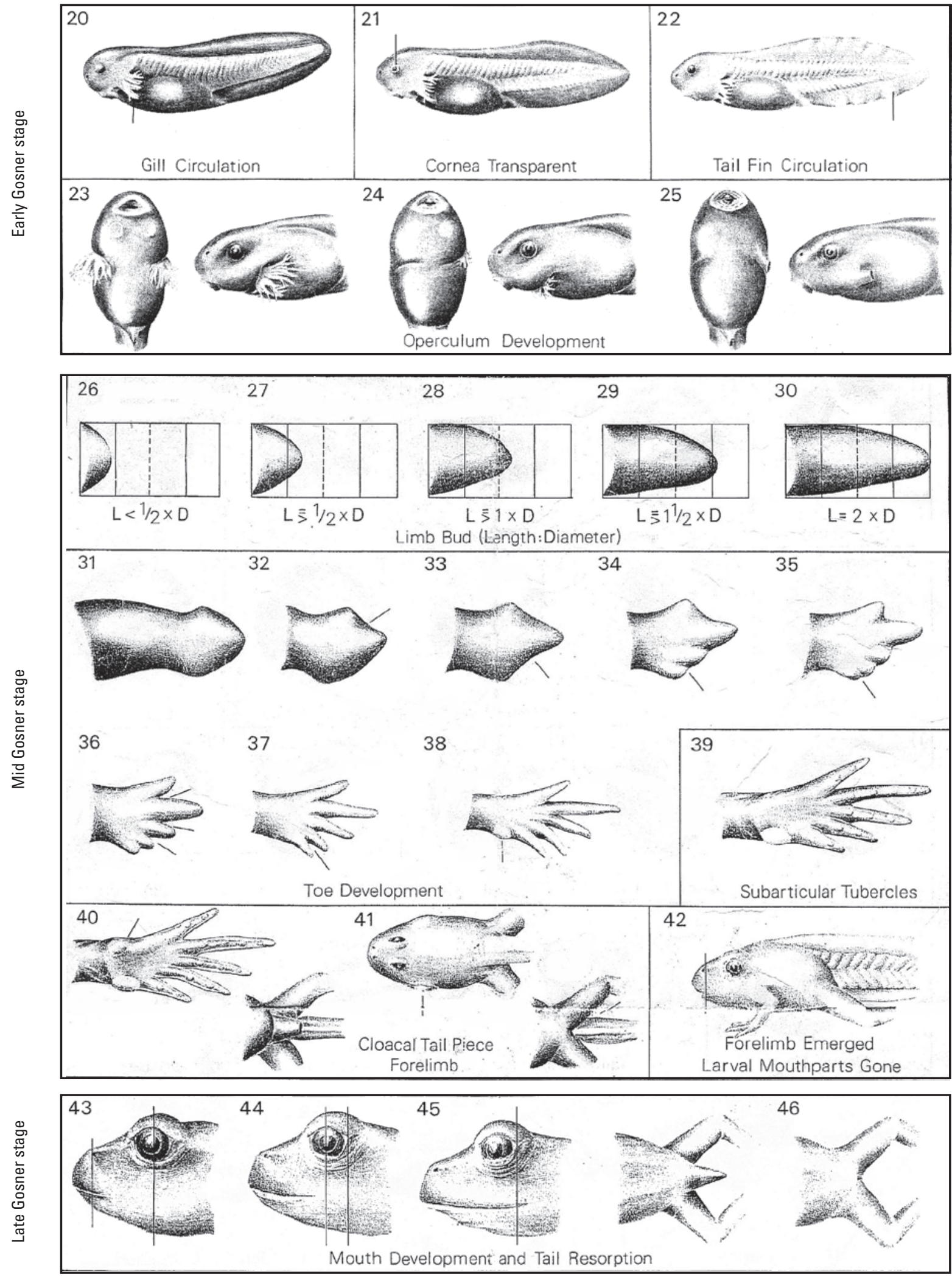

Figure 36. Gosner stages of tadpole development. 


\section{Population Estimates}

To determine baseline adult population estimates for each species across all sites, mark-recapture methods were implemented in 2006. Nocturnal visual encounter surveys were conducted for adult animals, and each adult was tagged with a unique toe-clip when captured to indicate a specific survey night (referred to as a batch mark). Upon recapture in subsequent surveys, individuals were recorded as marked or recaptured according to their batch mark. Because the population estimates are from within-year surveys, it is believed that the time between mark-recapture events is so brief (approximately one month) as to negate death, emigration, birth, and immigration to the population. The population size $(\mathrm{N}$ in the following equation) was estimated using an extension of the Lincoln-Peterson model for multiple visits, assuming a closed population (Schnabel method; Krebs, 1989):

$$
N=\frac{\sum_{t=1}^{t=T} n_{1} M_{t}}{\sum_{t=1}^{t=T} m_{t}}
$$

where

$$
\begin{gathered}
n_{t} \quad \text { is the total sample collected at the } t^{\text {th }} \text { time, } \\
M_{t} \quad \text { is the number of marked individuals in the } \\
\text { population just before the } \mathrm{t}^{\text {th }} \text { sample is } \\
\text { taken, } \\
m_{t} \quad \text { is the number of marked individuals collected } \\
\quad \text { in the sample at the } \mathrm{t}^{\text {th }} \text { time, and } \\
T \quad \text { is the number of marking events. }
\end{gathered}
$$

\section{Health Assessment}

Several parameters were used to evaluate the general health of the endemic anuran populations including the following: body-mass indices, ectoparasite checks, testing for the chytrid fungus Batrachochytrium dendrobatidis $(B d)$, and general pathological assessments. Although each endemic anuran captured was examined for ectoparasites, not all captures were examined for $B d$ or sent in for pathological assessments.

Body-mass indices are the ratio between body mass and body size (SVL; a linear measurement proxy for body size), and are considered a nondestructive alternative to estimating body conditions (Bancila and others, 2010). Testing for body conditions of animals involves looking at energy reserves (fat content), which results in destroying the animal. This alternative body-mass index is considered a nondestructive way of obtaining the same information. These data provide baseline body condition indices for these populations. Future comparisons of these data can be made, and will reflect the health and reproductive state of a species, as well as environmental characteristics such as habitat quality and prey availability (Anderson and Gutreuter, 1983; Ney, 1993).
Upon observing ectoparasites on endemic anurans at the Joshua Tree National Park (fig. 1), ectoparasite checks were instituted on all animals captured in 2006. The type of ectoparasite examined is the larval form of a chiggermites (Trombiculidae), hereafter referred to as chiggers. Chiggers appear as red-colored pustules, approximately $1 \mathrm{~mm}$ in diameter, under the dermis. Chiggers can cause inflammation and ulceration of the skin; although, whether they can transmit infectious diseases or not is not well established (Sladky and others, 2000). Following animal capture, counts on the number of chiggers embedded within the anuran skin were made.

The infectious disease, chytridiomycosis, has been linked to many amphibian declines worldwide (Berger and others, 1998; Longcore and others, 1999; Daszak and others, 2003; Lips and others, 2004). Chytridiomycosis is caused by $B d$, and attacks the keratinized parts of the body (Berger and others, 1998), affecting frogs during and after metamorphosis. Chytridiomycosis attacks the mouthparts of the larval stage, but is not fatal to tadpoles (Berger and others, 1998; Fellers and others, 2001). In 2005, all animal captures were swabbed for detection of $B d$ by following the procedures established by Boyle and others (2004). Animals were swabbed on the ventrum in accordance with USGS protocols (U.S. Geological Survey, 2006c). Tadpoles also were evaluated for $B d$ by checking toothrows for evidence of oral chytridiomycosis, by following the procedures of Fellers and others (2001), but not swabbed. In 2006, because of the time-intensive level of field work, only 10 animals were swabbed for $B d$ per species, per site, and per sampling night.

Amphibian population die-offs and local extinctions worldwide have been attributed to pathogens (Bosch and others, 2001; Muths and others, 2003; Lips and others, 2004). Samples of healthy and abnormal animals from each site were submitted to the USGS National Wildlife Health Center (NWHC) in Madison, Wisconsin, as part of the Amphibian Research and Monitoring Initiative (ARMI) project for pathological analysis. The ARMI is a federal organization dedicated to amphibian research and monitoring focusing on the prevention of amphibian declines (Muths and others, 2006). Viral, bacterial, and histological examinations were made by NWHC in attempts at early identification of an infectious disease and to develop baseline data on these populations.

\section{Voucher Specimens}

Voucher specimens were collected from the Darwin Falls, Piute Spring, and Fortynine Palms study areas (fig. 1; table 20). These animals were preserved and deposited in the USGS Museum Collections, San Diego, California, and GPS locations were recorded for each specimen. Each specimen has a field series tag, and an information tag that contains the species name, collector, collection date, collection site, and National Park Service (NPS) accession catalog number. 
Table 20. Catalog information for voucher specimens collected at Darwin Falls, Piute Spring, and Fortynine Palms Oasis study areas, Mojave Network Parks, California, 2005-06.

[Latitude and longitude are presented in degrees, minutes, seconds, referenced to the North American Datum of 1983 (NAD 83); CAS, California Academy of Sciences; DEVA, Death Valley National Park; JOTR, Joshua Tree National Park; xx/xx/xxxx, month/day/year]

\begin{tabular}{|c|c|c|c|c|}
\hline $\begin{array}{l}\text { Field } \\
\text { number }\end{array}$ & $\begin{array}{l}\text { Collections } \\
\text { number }\end{array}$ & $\begin{array}{l}\text { Species } \\
\text { of interest }\end{array}$ & Date & $\begin{array}{l}\text { Location } \\
\text { and notes }\end{array}$ \\
\hline RNF 5272 & CAS 244140 & $\begin{array}{l}\text { Red-spotted toad } \\
\text { (Anaxyrus punctatus) }\end{array}$ & $05 / 10 / 05$ & $\begin{array}{l}\text { Piute Springs, } 35^{\circ} 06^{\prime} 39^{\prime \prime}, 114^{\circ} 59^{\prime} 26^{\prime \prime} \text { (NAD 83), San Bernardino } \\
\text { County, tadpoles (4). }\end{array}$ \\
\hline RNF 5343 & DEVA 53730 & $\begin{array}{c}\text { Western toad } \\
\text { (Anaxyrus boreas) }\end{array}$ & $05 / 11 / 05$ & Darwin Falls, $36^{\circ} 19^{\prime} 15^{\prime \prime}, 117^{\circ} 31^{\prime} 05^{\prime \prime}$ (NAD 83), Inyo County, adult. \\
\hline RNF 5391 & JOTR29725 & $\begin{array}{c}\text { California treefrog } \\
(\text { Pseudacris cadaverina })\end{array}$ & $06 / 23 / 05$ & $\begin{array}{l}\text { Fortynine Palms Oasis, } 34^{\circ} 06^{\prime} 20^{\prime \prime}, 116^{\circ} 06^{\prime} 19^{\prime \prime} \text { (NAD 83), } \\
\quad \text { San Bernardino County, tadpole. }\end{array}$ \\
\hline RNF 5392 & JOTR29726 & $\begin{array}{c}\text { California treefrog } \\
\text { (Pseudacris cadaverina) }\end{array}$ & $06 / 23 / 05$ & $\begin{array}{l}\text { Fortynine Palms Oasis, } 34^{\circ} 06^{\prime} 20^{\prime \prime}, 116^{\circ} 06^{\prime} 19^{\prime \prime} \text { (NAD 83), } \\
\text { San Bernardino County, tadpole. }\end{array}$ \\
\hline
\end{tabular}

\section{Biological Results}

The biological surveys completed during the 2005 and 2006 collected data on the reproduction, population, and overall health of the endemic anuran species at the Darwin Falls, Piute Spring, and Fortynine Palms Oasis study areas. The results of these surveys and available historical biological data are presented for each of the study areas.

\section{Darwin Falls, Death Valley National Park}

Biological surveys were completed in the Darwin Falls study area from Darwin Falls downstream to where the canyon widens and water no longer flows (fig. 6). Biological surveys were focused on the western toad (Anaxyrus boreas; fig. 5D).

\section{Reproduction}

Reproduction appears to begin in April at Darwin Falls (fig. 2); greater than or equal to 4,000 tadpoles were observed in their early stage of development. The data indicate a slow tapering of numbers of tadpoles in May, with less tadpole density (less than 2,000) and all in the mid-stage of development, and a final decline in July with few tadpoles present (approximately 60), but representing all stages of tadpole development.

\section{Population Estimates}

Personnel from the Death Valley National Park completed population surveys of the western toad population in Darwin Falls between 1997 and 1999 (appendix 4; Doug Threloff, Death Valley National Park, unpub. data, 1999) from an area approximately half the size of the area surveyed for this study in 2005 and 2006. The western toad population estimated from these data was 180 adults (95-percent confidence interval [CI] of 128-300) (Doug Threloff, Death Valley National Park, unpub. data, 1999).

In 2006, four mark-recapture events took place between April 26 and May 31 to reassess the western toad population at the Darwin Falls study area (table 21). For the purpose of estimating populations, toads recaptured with passive integrated transponder (PIT) tags from 2005 (appendix 5), and those tagged in the Death Valley area between 1997 and 1999 (appendix 4) were considered first-time captures and were not toe-clipped. A total of 552 adult toads were observed in 2006 (table 21). Using the Schnabel multiple recapture model (Krebs, 1989), the population of western toads in 2006 was estimated to be 381 adults (95-percent CI of 314-482; table 21).

\section{Health Assessment}

Ratios of western toads' body mass to SVL, which provide an index of general body condition, were recorded in 2005 and 2006 (fig. 37). The 2005 surveys focused on adults, whereas the 2006 surveys measured all age classes. In general, the toads had more body mass per SVL in 2005 than in 2006 (fig. 37). No parasites were observed on western toads in 2006, and $B d$ was not detected in 2005 or 2006. Of the tadpoles that possessed visual abnormalities, four were tested for viruses with negative results; one tadpole exhibiting an abnormal narrowing (atresia) of the spiracle opening, and two carried myxosporean parasites (Myxidium spp.) in their gall bladders (table 22). In 2006, two healthy, recently metamorphosed toads tested negative for viruses. A single adult western toad was collected in 2005 to illustrate the rare ranidlike skin of the toad and was deposited in the USGS Museum Collections (table 20). 
Table 21. Population estimates for the species of interest at Darwin Falls, Piute Spring, and Fortynine Palms Oasis study areas, Mojave Network Parks, California, 2005-06.

[Schnabel method (Krebs, 1989); \%, percent; CI, confidence interval; xx/xx/xxxx, month/day/year]

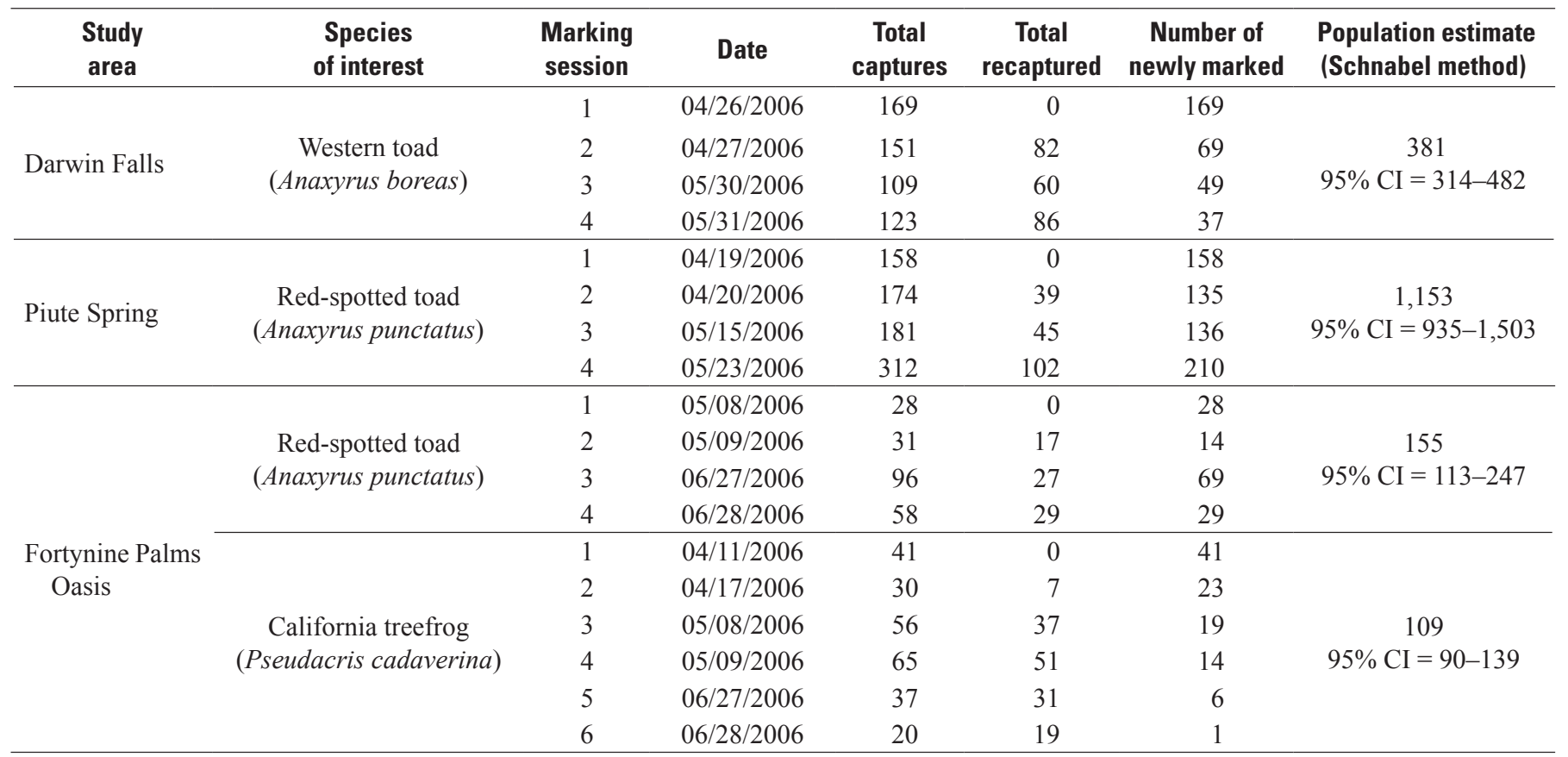

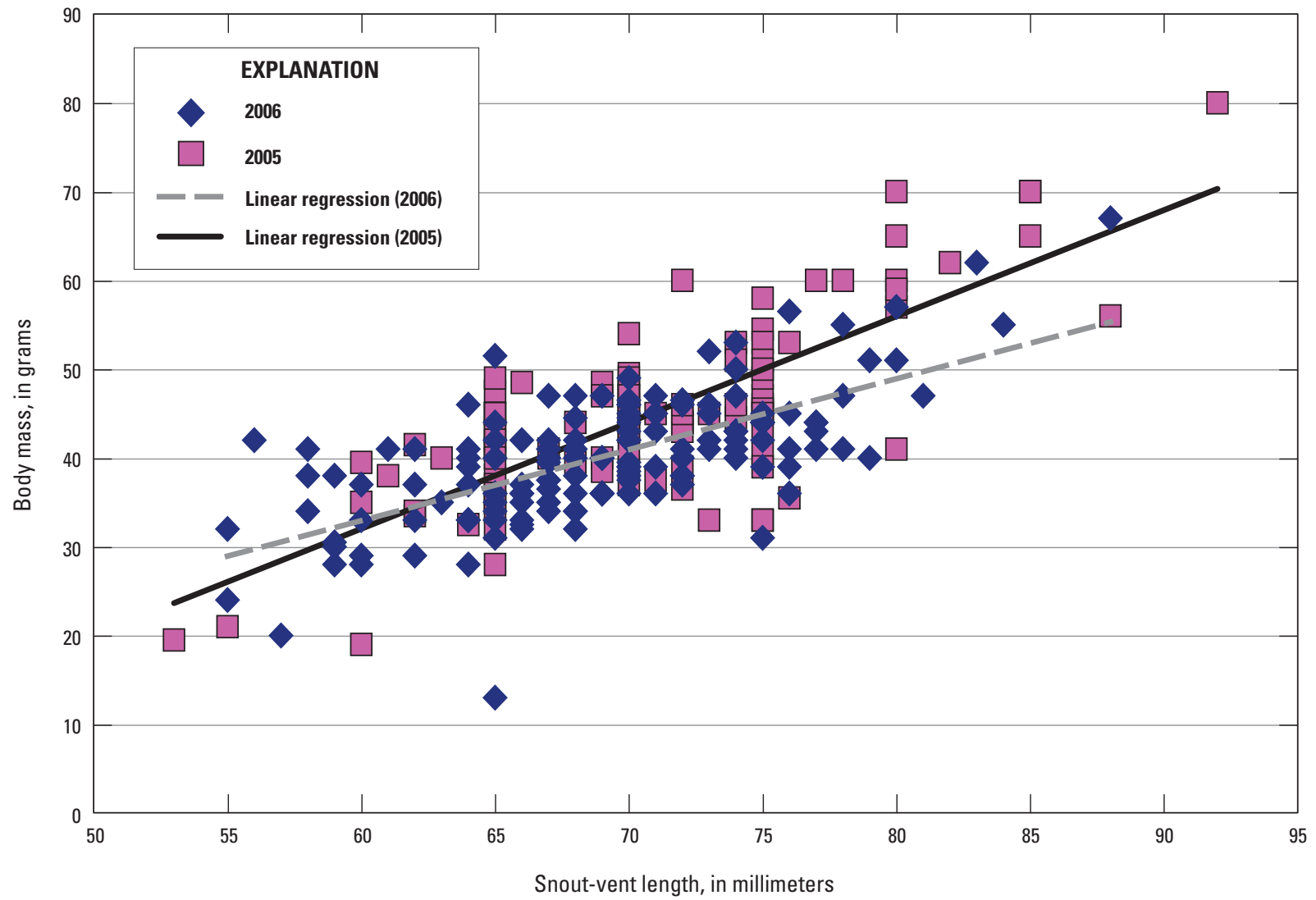

Figure 37. Western toad (Anaxyrus boreas) body mass as compared with snout-vent length at Darwin Falls study area, Death Valley National Park, California, 2005-06. 
Table 22. Pathology results from the U.S. Geological Survey (USGS) National Wildlife Health Center for targeted endemic anuran samples from Darwin Falls, Piute Spring, and Fortynine Palms Oasis study areas, Mojave Network Parks, California, 2005-06.

[V-, virus not detected; V+, virus detected; B-, bacterial infection not detected; B+, bacterial infection detected; N/A, not available; - , no data; LHL, left hindlimb; FL, forelimb; RHL, right hindlimb; HL, hindlimb; xx/xx/xxxx, month/day/year]

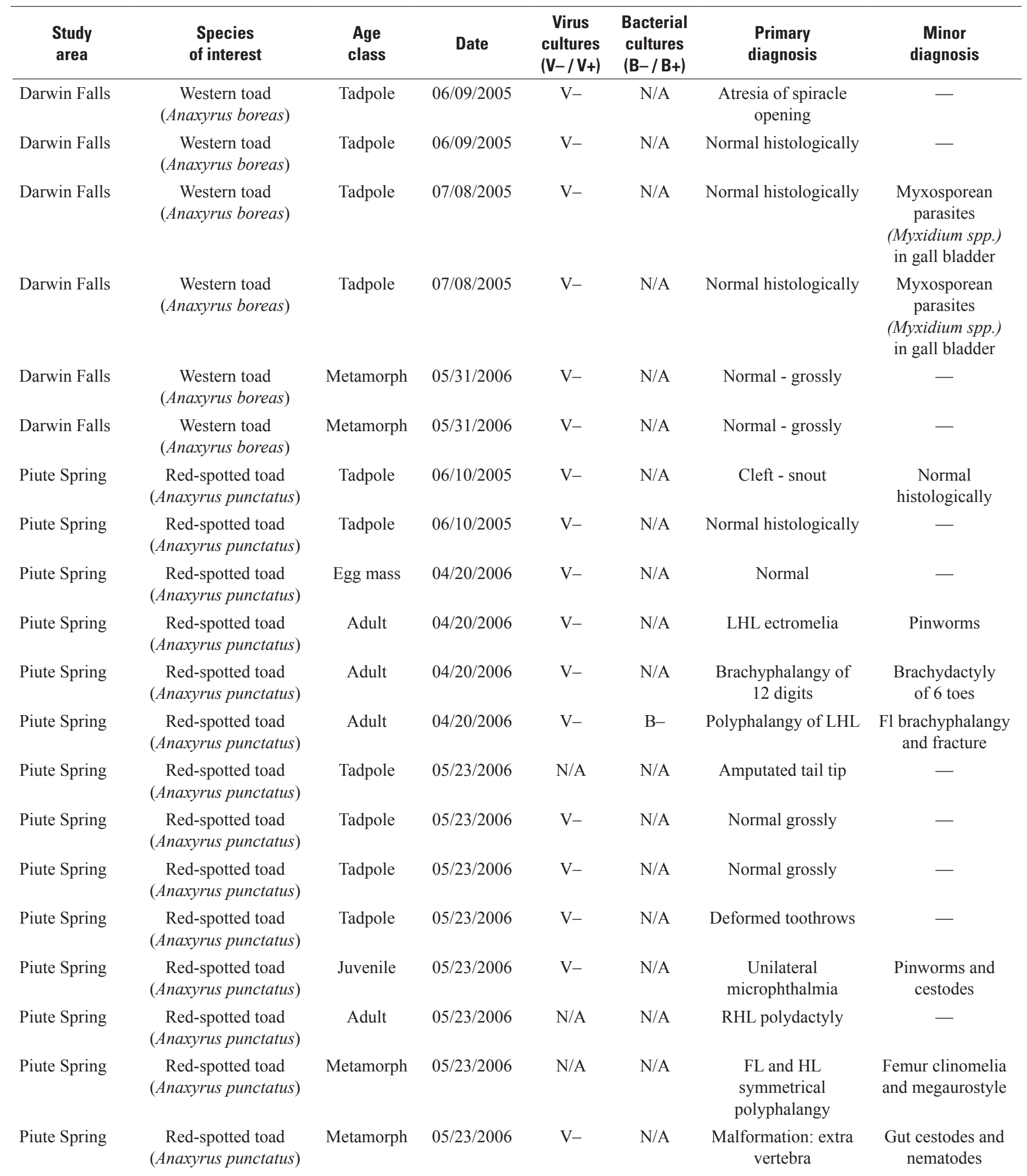


Table 22. Pathology results from the U.S. Geological Survey (USGS) National Wildlife Health Center for targeted endemic anuran samples from Darwin Falls, Piute Spring, and Fortynine Palms Oasis study areas, Mojave Network Parks, California, $2005-06$.

-Continued

[V-, virus not detected; V+, virus detected; B-, bacterial infection not detected; B+, bacterial infection detected; N/A, not available; -, no data; LHL, left hindlimb; FL, forelimb; RHL, right hindlimb; HL, hindlimb; xx/xx/xxxx, month/day/year]

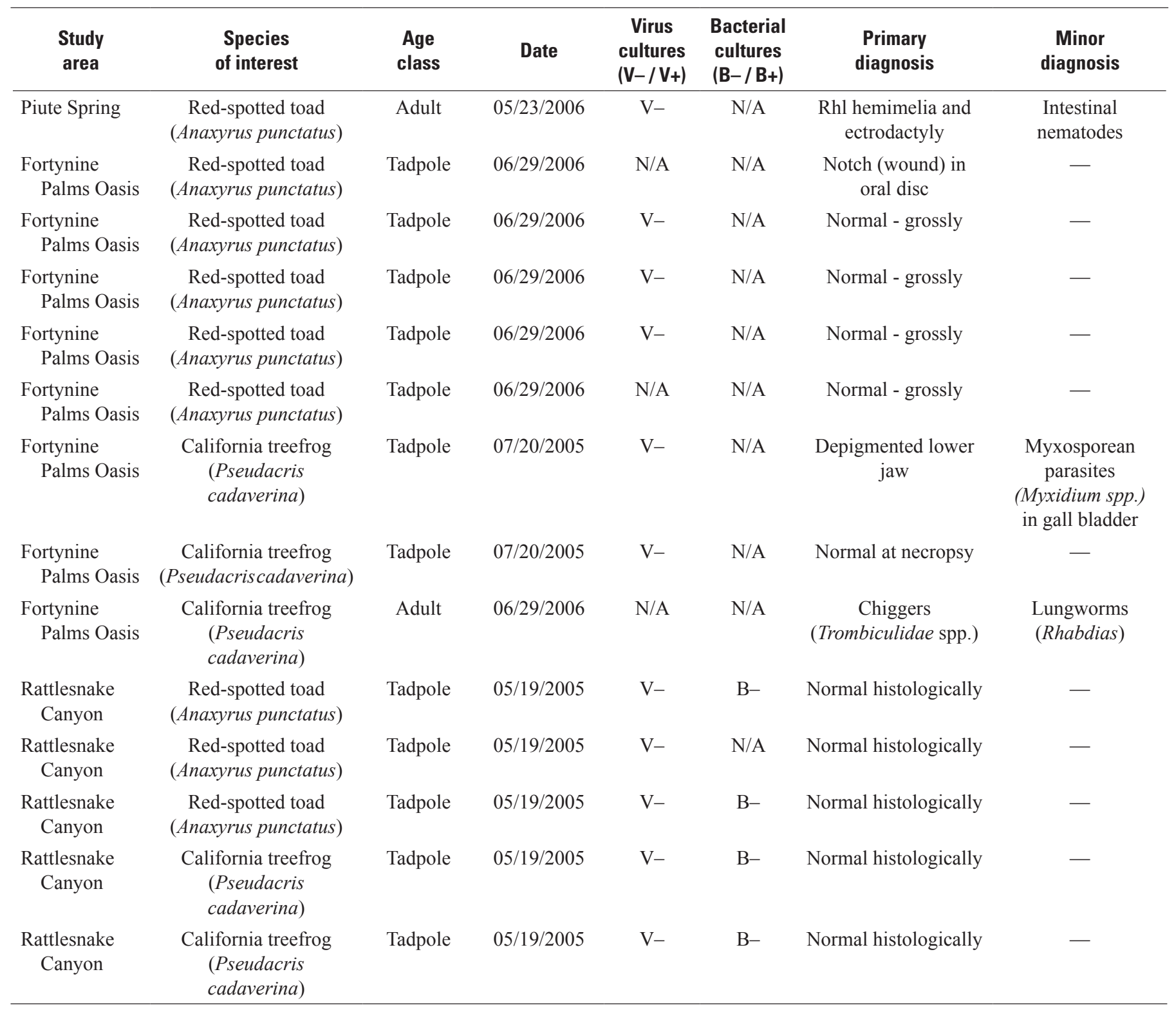




\section{Piute, Mojave National Preserve}

Biological surveys were completed along Piute Canyon from Piute Spring to about $1.2 \mathrm{~km}$ downstream (fig. 11). Biological surveys were focused on the red-spotted toad (Anaxyrus punctatus), which was the only amphibian present at this site (fig. 10E). In 2005, biological surveys for the red-spotted toad in the study area did not extend all the way upstream to Piute Spring (fig. 11) because of dense vegetation near Piute Spring. Flash floods in Piute Canyon during August 2005 cleared away much of the dense vegetation near the spring, allowing biological surveys in 2006 to extend all the way from Piute Spring to the downstream locations surveyed in 2005 (fig. 11).

\section{Reproduction}

In April, approximately 3,000 tadpoles observed were in the early stage of development. In May, approximately 5,000 tadpoles were observed representing all stages of development, but with the majority in the early stage of development. By July, tadpole counts remained high (approximately 3,000) with all stages of development represented and most still within the early stage of development.

\section{Population Estimates}

Four mark-recapture events for the red-spotted toad took place between April 19 and May 23, 2006 (table 21). A total of 825 adult toads were observed in 2006 with 639 individual captures (table 21). By using the Schnabel multiple recapture model (Krebs, 1989), the population of red-spotted toads was estimated to contain 1,153 adults (95-percent CI of 935-1,503; table 21).

\section{Health Assessment}

Body mass and SVL of adult red-spotted toads were measured in 2005; body mass and SVL of toads in age classes from those recently metamorphosed to those that had reached adulthood were measured in 2006 (fig. 38). In general, the toads had more body mass per SVL in 2006 than in 2005 (fig. 38). Checks for parasites began in 2006, but only three individuals carried chiggers. Of 43 toads swabed in 2006, $B d$ was detected in three toads. In 2005, two toads were submitted to the NWHC for pathological assessment, and one toad was diagnosed with a cleft snout (table 22).

In 2005 and 2006 surveys, 60 abnormality types (table 23; Meteyer, 2000) were detected in 59 red-spotted toads (a single toad exhibited 2 abnormalities) out of the 1,321 toads observed (table 24). In an attempt to prevent the over estimation of abnormalities, surveys were analyzed based on a single night's effort. The adult life stage had the most abnormalities, and most of all abnormalities occurred within the hind limbs (table 24). Approximately 38 percent of these hindlimb abnormalities were categorized as ectrodactyly (missing toes; table 24). The abnormalities included those affecting the phalanges, including polyphalangy (excess number of phalanges; fig. 39B) and brachyphalangy (short phalanges; fig. 39C); , ectromelia (missing limb; fig. 39A) and hemimelia (shortened bone) of limbs; and, micropthalmia (missing eye; fig. 39D) of one or more eyes. In addition, other abnormalities affecting entire toes or the curvature of bones were detected (table 24).

\section{Fortynine Palms Oasis, Joshua Tree National Park}

Biological surveys were initially completed throughout the wetted reach at the Fortynine Palms Oasis and were later extended upstream of the Upper Pool (fig. 16). Biological surveys focused on the red-spotted toad (Anaxyrus punctatus) and the California treefrog (Pseudacris cadaverina; figs. 15D and $15 E$ ), the two endemic anuran species present at this site.

\section{Reproduction}

\section{Red-Spotted Toad}

Tadpoles were not observed during the April and May surveys, but were observed in June in numbers greater than or equal to 1,000 . Only two pools within a $125-\mathrm{m}$ segment of the survey area contained tadpoles, mostly in early-stage development with few in the mid-stage of development.

\section{California Treefrog}

A single treefrog was observed during the daytime visual encounter surveys in April 2006, but two tadpoles each were recorded in May and June during nighttime visual encounter surveys. The tadpoles observed in May were in the mid-stage of their development, and those observed in June were in the late stage.

\section{Population Estimates}

\section{Red-Spotted Toad}

Four mark-recapture events for the red-spotted toad at Fortynine Palms Oasis (fig. 12) occurred between May 8 and June 28, 2006 (table 21). A total of 213 adult toads were observed in 2006, and 140 of those were batch marked to represent each sampling night (table 21). By using the Schnabel multiple recapture model (Krebs, 1989), the population of redspotted toads was estimated to contain 155 adults (95-percent CI of 113-247; table 21). 


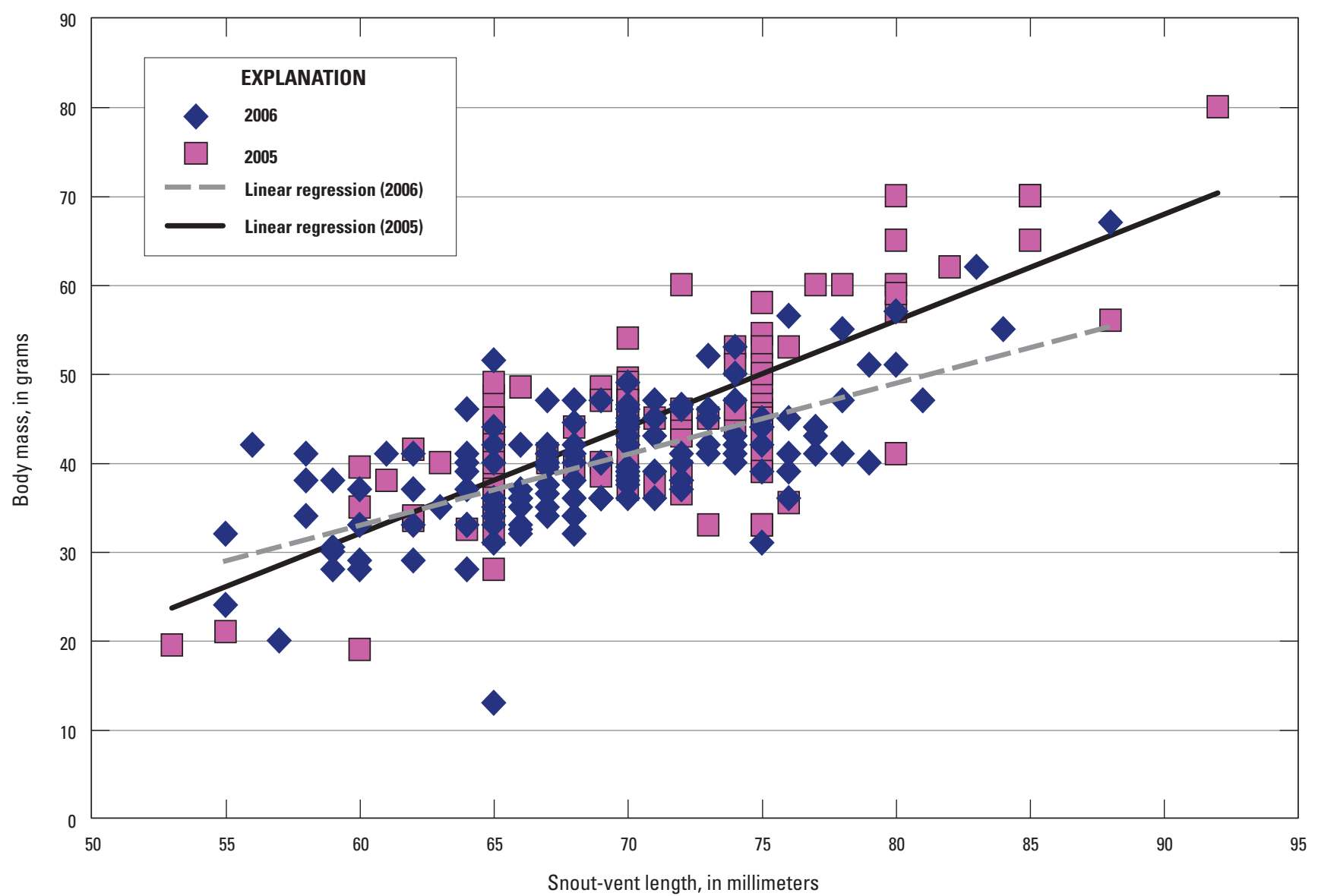

Figure 38. Red-spotted toad (Anaxyrus punctatus) body mass as compared with snout-vent length at Piute Spring study area, Mojave Network Parks, California, 2005-06.

Table 23. Classification and definition of abnormalities present in red-spotted toads (Anaxyrus punctatus) at Piute Spring study area, Mojave Network Parks, California, 2005-06.

\begin{tabular}{|c|c|c|}
\hline $\begin{array}{l}\text { Location of } \\
\text { abnormality }\end{array}$ & $\begin{array}{c}\text { Type of } \\
\text { abnormality }\end{array}$ & $\begin{array}{l}\text { Description of } \\
\text { abnormality }{ }^{1}\end{array}$ \\
\hline Craniofacial & Anophthalmia & Missing eye. \\
\hline Craniofacial & Paratoid development & Poorly developed paratoid glands. \\
\hline Forelimb and hindlimb & Ectromelia & An incomplete limb with the lower part of the leg missing. \\
\hline Forelimb and hindlimb & Polyphalangy & $\begin{array}{l}\text { Normal number of metatarsal bones at the tibia-fibulare metarsal joint, but with } \\
\text { duplicate sets of phalanges. }\end{array}$ \\
\hline Forelimb and hindlimb & Phocomelia & $\begin{array}{l}\text { Absence of the proximal portion of a limb, with foot attached close to body and } \\
\text { proximal bones which cannot be identified. }\end{array}$ \\
\hline
\end{tabular}

\footnotetext{
${ }^{1}$ Description of abnormalities taken from Meteyer (2000).
} 
Table 24. Percentage of abnormality types in red-spotted toads (Anaxyrus punctatus) observed at Piute Spring study area, Mojave Network Parks, California, 2005-06.

\begin{tabular}{lcc}
\hline \multicolumn{1}{c}{$\begin{array}{c}\text { Abnormality } \\
\text { type }\end{array}$} & Number & Percentage \\
\hline Anophthalmia & Craniofacial & \\
Microphthalmia & 1 & 1.7 \\
Paratoid development & 2 & 3.3 \\
& 1 & 1.7 \\
\hline Ectromelia & Forelimb & \\
Brachydactyly & 2 & 3.3 \\
Ectrodactyly & 3 & 5.0 \\
Polyphalangy & 3 & 5.0 \\
Phocomelia & 2 & 3.3 \\
\hline & 1 & 1.7 \\
\hline Ectromelia & Hindlimb & 6.7 \\
Brachydactyly & 4 & 13.3 \\
Ectrodactyly & 8 & 38.3 \\
Polyphalangy & 23 & 8.3 \\
Phocomelia & 5 & 1.7 \\
Hemimelia & 1 & 1.7 \\
Rotation of tibia-fibulare & 1 & 5.0 \\
\hline Total & 3 & \\
\hline 'See & & \\
\hline
\end{tabular}

${ }^{1}$ See table 23 for description of abnormality types. 

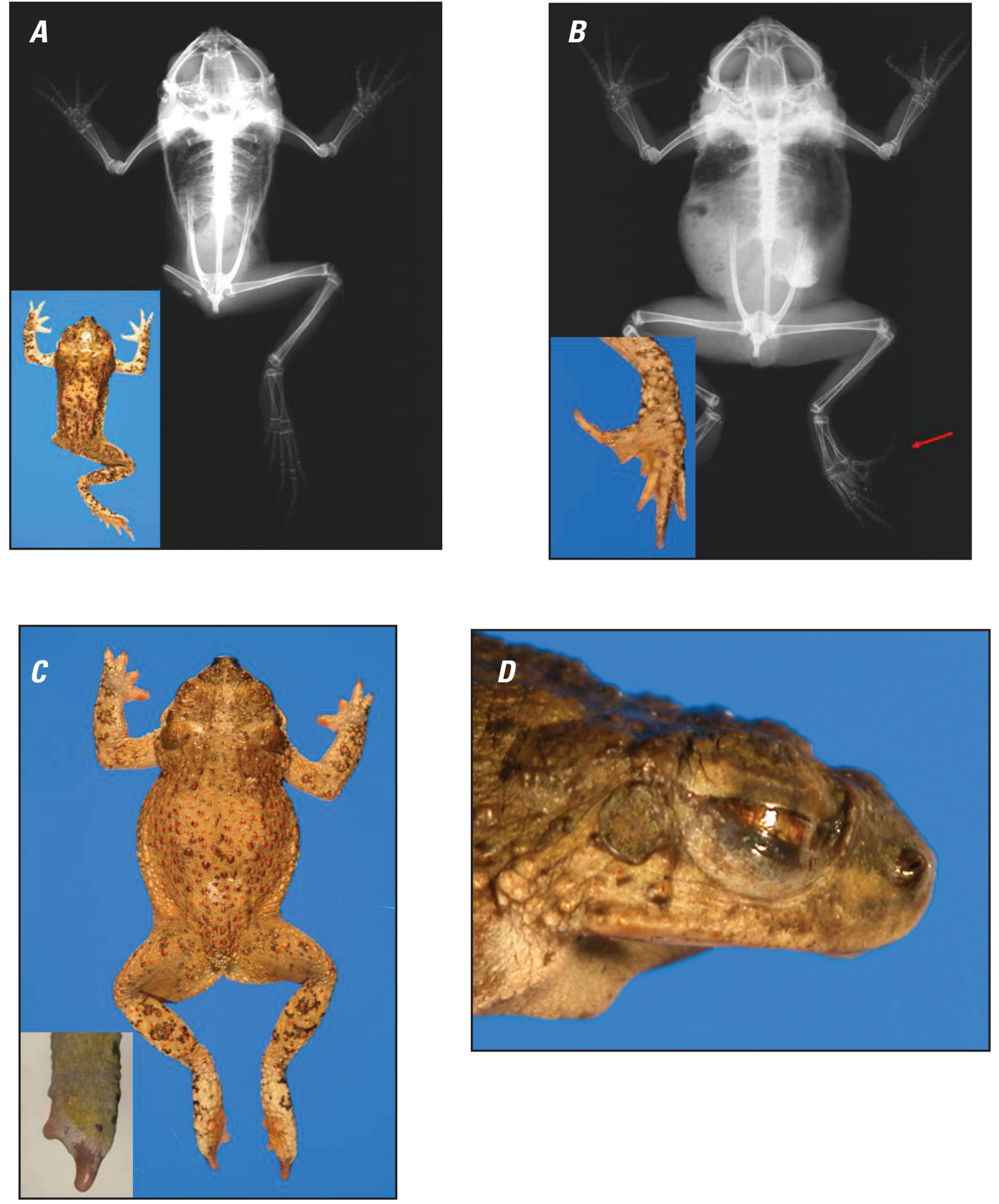

Figure 39. Abnormalities observed in red-spotted toads (Anaxyrus punctatus) at Piute Spring study area, Mojave Network Parks, California, 2005-06. A, Ectromelia of hindlimb. B, Polyphalangy of hindfoot. C, Brachyphalangy of hindfoot. D, Possible microphthalmia of the eye. 


\section{California Treefrog}

Six mark-recapture events for the California treefrog at Fortynine Palms Oasis (fig. 12) took place between April 11 and June 28, 2006 (table 21). A total of 249 adult treefrogs were observed in 2006 with 104 of those marked with individual unique toe-clip numbers. By using the Schnabel multiple recapture model (Krebs, 1989), the population of treefrogs was estimated to contain 109 adults (95-percent CI of 90-139; table 21).

\section{Health Assessment}

\section{Red-Spotted Toad}

The relation between body mass and SVL for red-spotted toads at Fortynine Palms Oasis (fig. 12) provides a baseline index of the general body condition for this site (fig. 40). As at the other study areas, only adult animals were measured in 2005. All age classes, from those recently metamorphosed to adults, were measured in 2006. In general, adult red-spotted toads had greater body mass per SVL in 2005 than in 2006 (fig. 40). The largest red-spotted toad determined by SVL was $63 \mathrm{~mm}$ in 2006 and, the largest red-spotted toad determined by body mass was $20 \mathrm{~g}$ in 2005 (fig. 40). In general, the toads at Fortynine Palms Oasis had less body mass per SVL than did the toads at Piute Creek (fig. 41).

Five red-spotted toad tadpoles collected in 2006 from Fortynine Palms Oasis (fig. 12) were sent to the USGS NWHC for general health screening (table 22). Three of those animals had virus cultures completed with no viruses being isolated. The remaining animals were not tested for viruses, but they appeared to be normal and healthy. One tadpole exhibited signs of injury, a notch wound in the oral disc, but no other significant injuries or abnormalities were observed.

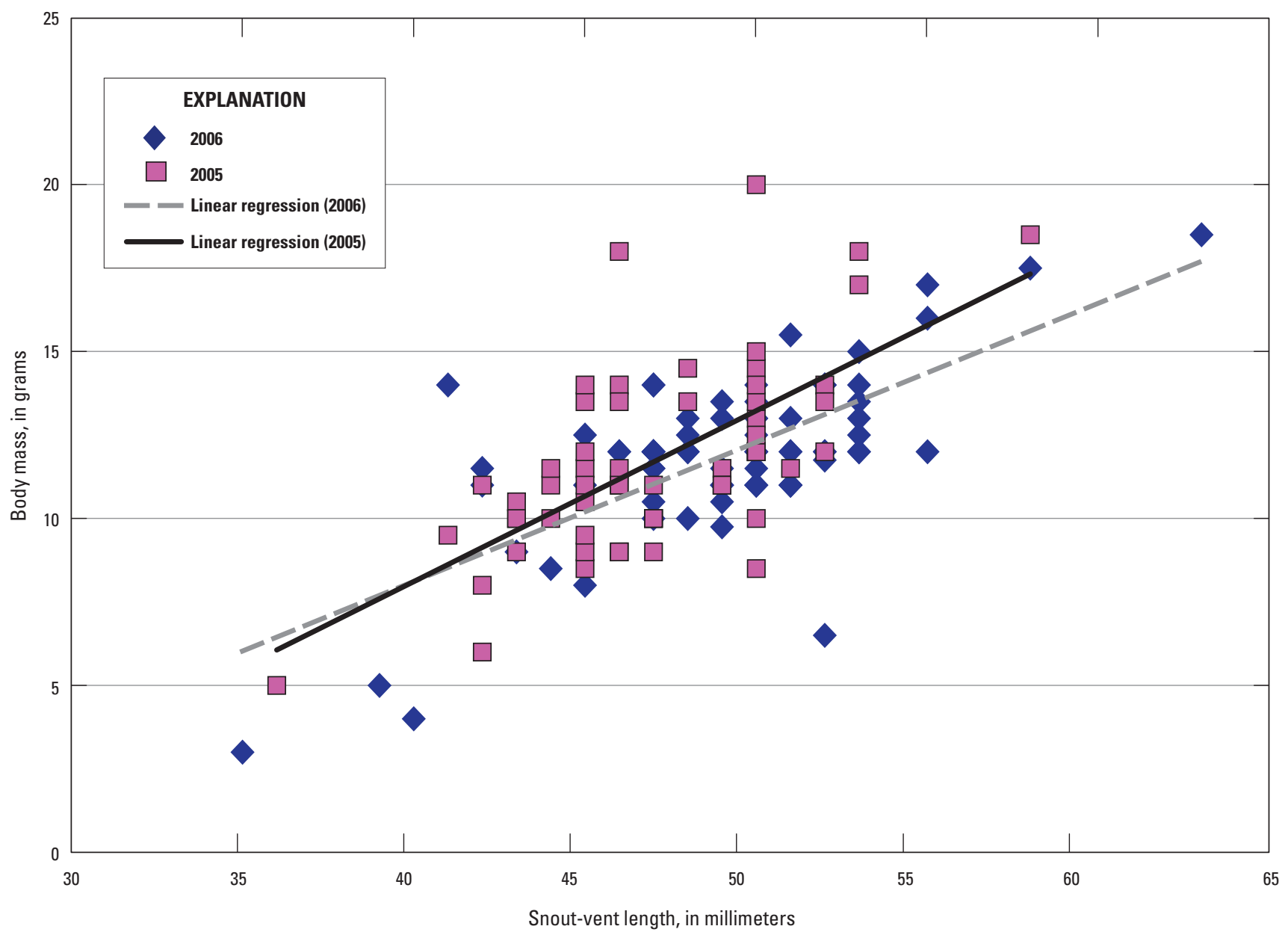

Figure 40. Red-spotted toad body mass as compared with snout-vent length at Fortynine Palms Oasis study area, Mojave Network Parks, California, 2005-06. 


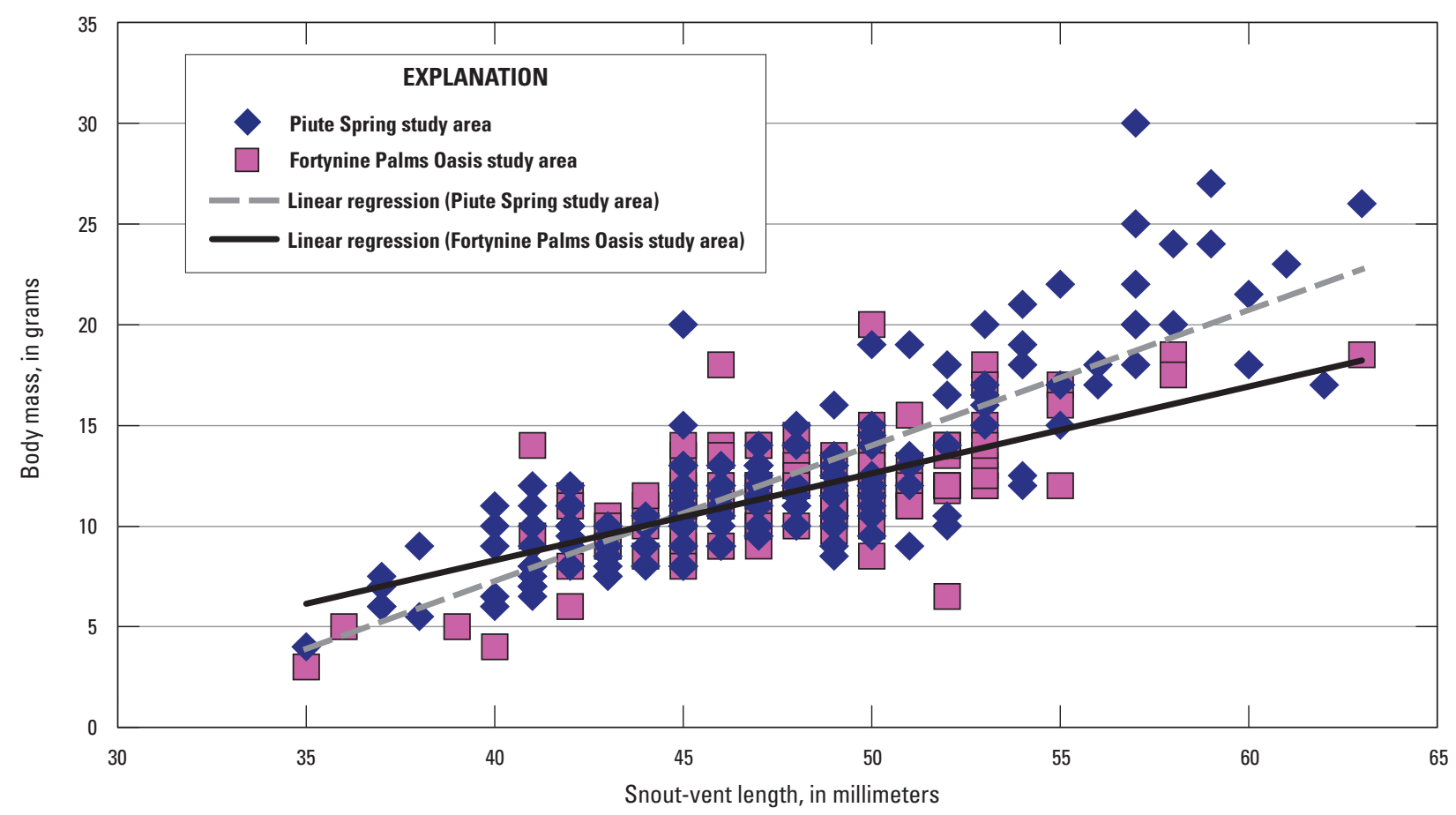

Figure 41. Comparison of the body mass as compared with snout-vent length between red-spotted toads from Fortynine Palms Oasis and Piute Spring study areas, Mojave Network Parks, California, 2005-06.

\section{California Treefrog}

Only adult California treefrogs were measured in 2005. All age classes, from those recently metamorphosed to adults, were measured in 2006. In general, adult treefrogs had more body mass per SVL in 2005 than in 2006 (fig. 42). The largest frog was observed in 2005, and had a SVL of $53 \mathrm{~mm}$ and a body mass of $13 \mathrm{~g}$ (fig. 42).

Three California treefrogs collected in 2005 and 2006 from Fortynine Palms Oasis (fig. 12) were sent to the USGS NWHC for general health screening (table 22). One animal had a depigmented lower jaw and another animal had chiggers (Trombiculidae.) and lungworms (Rhabdias), and all animals tested negative for viruses (table 22).

Welbourn and Loomis (1975) reported that chigger mites (Trombiculidae) occur on California treefrogs and red-spotted toads at Fortynine Palms Oasis. Comparisons of the endemic anurans at Fortynine Palms Oasis (fig. 12) in this study will be made in the following "Discussion" section of this report to those of Welbourn and Loomis (1975) who studied the ectoparasites on red-spotted and California treefrogs at the Joshua Tree National Park (fig. 1) from 1969 to 1971. In 2006, a total of 241 red-spotted toads (from 4 surveys) and 238 treefrogs (from 6 surveys) at Fortynine Palms Oasis (fig. 12) were checked for chiggers (Trombiculidae; fig. 43). Approximately 5 percent of all red-spotted toads surveyed had an average of 10.1 parasites per individual. About 57 percent of all treefrogs surveyed had an average of 21.2 parasites per individual.
A total of 30 red-spotted toad and 52 California treefrog swab samples from both years were sent to the department of Conservation and Research for Endangered Species (CRES), Wildlife Disease Laboratory at the San Diego Zoo, for realtime polymerase chain reaction (PCR) detection of $B d$. Redspotted toads tested positive for $B d$, and California treefrogs did not.

\section{Rattlesnake Canyon, Joshua Tree National Park}

A single survey of Rattlesnake Canyon (fig. 12) was done in 2005 to investigate the possible presence of red-spotted toads and California treefrogs. This canyon consisted of numerous drying pools that contained both species of endemic anurans. Five tadpoles were collected from drying pools (three red-spotted toads and two California treefrogs; table 22). All animals appeared healthy, and cultures tested negative for viruses and bacteria (table 22).

Swab samples from two red-spotted toads and two California treefrogs were sent to the CRES, Wildlife Disease Laboratory at the San Diego Zoo, for real-time PCR detection of $B d$. No $B d$ was detected.

No voucher specimens of red-spotted toads were obtained from this site, but two California treefrog tadpoles were collected from a drying pond in June 2005 (table 20). These specimens were collected under research permit number JOTR-2005-SCI-0024 and were deposited in the USGS Museum Collections. 


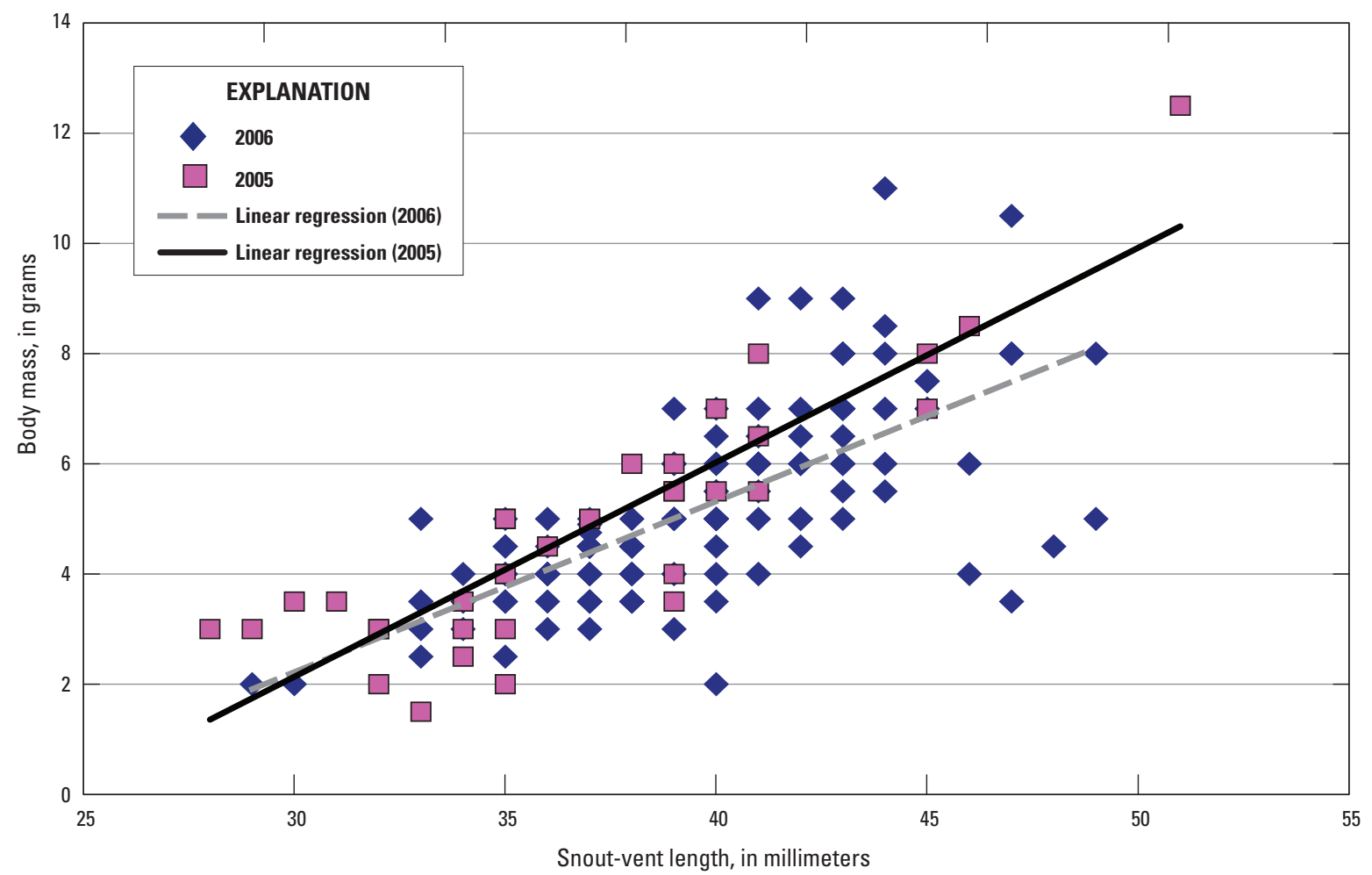

Figure 42. California treefrog body mass as compared with snout-vent length at Fortynine Palms Oasis study area, Mojave Network Parks, California, 2005-06.

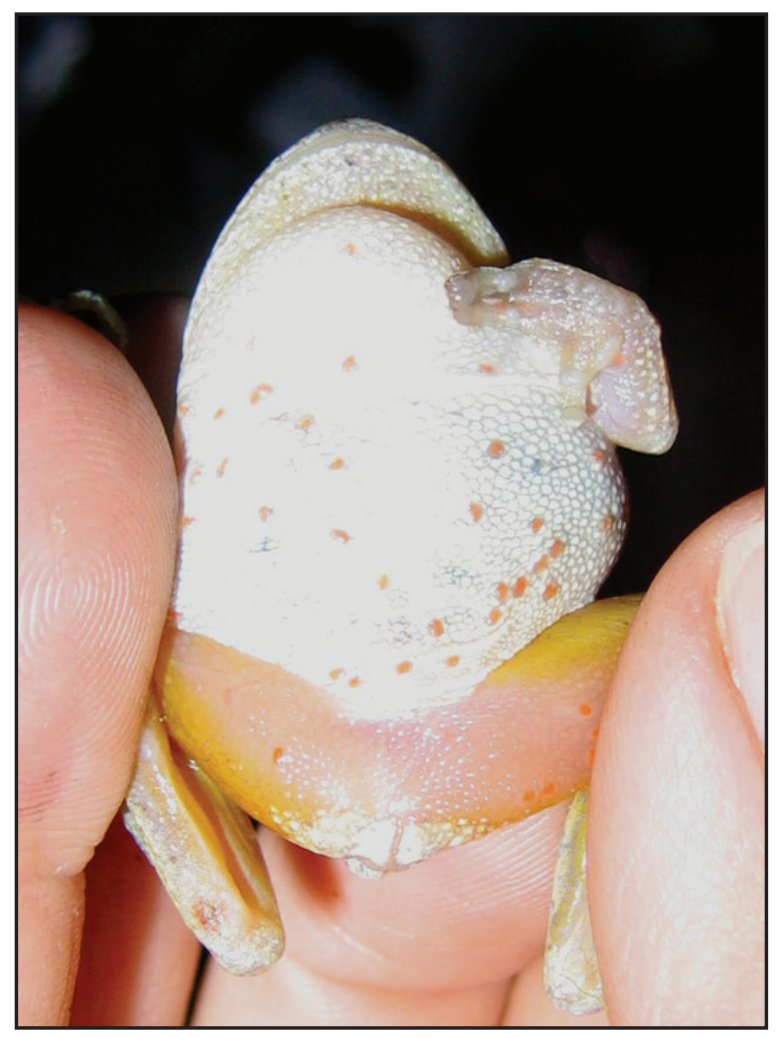

Figure 43. California treefrog (Pseudacris cadaverina) with chigger mites (Trombiculidae) at Fortynine Palms Oasis study area, Mojave Network Parks, California, 2005-06.

\section{Biological Discussion}

Data collected from the biological surveys completed for this study were evaluated to document the reproduction, estimate the population, and assess the overall health of each of the endemic anuran species present at the Darwin Falls, Piute Spring, and Fortynine Palms Oasis study areas. Where available, historical biological data also were evaluated.

\section{Darwin Falls, Death Valley National Park}

Historically, Darwin Falls (fig. 2) hosted the western toad and the red-spotted toad, where both existed at the edge of their range. The red-spotted toad was known to occur in many areas throughout the Death Valley National Park (Turner and Wauer, 1963), and is currently abundant in the Furnace Creek and Nevares Spring areas (fig. 1; Persons and Nowak, 2006; Doug Threloff, Death Valley National Park, unpub. data, 1996). The last verified sightings of the red-spotted toad in Darwin Canyon (fig. 4) were made by Feder (1979), where the western toad and the red-spotted toad were hybridizing. According to Persons and Nowak (2006), an unverified sighting of red-spotted toads was made at Darwin Falls (fig. 2) in 2003; however, the 2005 and 2006 surveys for this study failed to detect any. Red-spotted toads occur primarily in patchy populations (Bradford and others, 2003), but also occur in isolated mountain ranges, and such isolation makes 
colonization from outside source populations less likely. Because this species was isolated in the Argus Mountain Range at Darwin Falls (fig. 2), it is unlikely to recolonize and is therefore assumed to be extirpated.

The western toad is indigenous to Darwin Falls (fig. 2), where it is located throughout the study area. The western toad was introduced into the Furnace Creek area of the Death Valley National Park within the past 40 years (fig. 1). The population in 2006 is estimated to contain 381 adults (95-percent CI of 314-482), ranging in location from the base of Darwin Falls (fig. 2) all the way downstream to where the surface water disappears beneath the sand just above the parking area (about 1.25 kilometeres [km] from Darwin Falls). In 2006, more animals were present in the upper half than in the lower half of the study area, where they had likely migrated because of the greater availability of perennial flow. Crayon (1999) suggested that diversion by gravity flow through a pipe from Darwin Wash below the USGS gaging station to the Panamint Springs Resort (fig. 2) was a potential cause for decreasing water in the stream; however, given the small size of this resort it appears unlikely that domestic consumption could ever represent more than a few percent of the mean annual base flow of $0.25 \mathrm{cfs}$ (table 10), even during brief periods of high occupancy. Long-term monitoring results from the USGS gaging station on Darwin Wash (fig. 6), presented in the "Hydrogeological Results and Discussion" section of Chapter $\mathrm{B}$ of this report, indicates a slight upward trend in base flow since 1974 (fig. 19), which is not consistent with Crayon's observation of decreasing water availability in Darwin Creek. Reduced flow in the lower reaches of Darwin Creek, if occurring, could be explained by the trend of gradually increasing temperature minimums in the Mojave Desert (figs. 1 and 34) since about 1950 as this ought to be accompanied by increased evapotranspiration.

Records document that 6.1 to 8.5 years elapsed between the initial western toad captures in a 1997-99 study and the recaptures by this study in 2006 ( $n=26$ recaptures; appendix 4, 5). Adult western toads become sexually mature in 4 to 6 years across their range (Carey, 1976; Carey and others, 2001) at an SVL of 56-108 $\mathrm{mm}$ for males and 60-125 mm for females. Insofar as the standard size for PIT-tagging western toads is $55 \mathrm{~mm}$, it can be assumed that the animals PIT-tagged during the earlier survey would have been 3 to 4 years old at initial capture, which implies toads recaptured in 2006 were at least 9 to 11.5 years old. Campbell (1976) reported that most western toads lived to at least 9 years of age in a Colorado population, although they are thought to possibly live longer (Muths and Corn, 2000).

Western toads have been documented to move, on average $900 \mathrm{~m}$ from their summer to their fall habitat (Campbell, 1970) and as much as 439 m daily (Bartelt, 2000). Significant movement of recaptured toads was not observed during this study; however, it would be more informative to survey annually, or even seasonally, to look at movement patterns.
Reproduction of western toads at Darwin Falls (fig. 2) appears to begin in April and taper off in July. This correlates with the timing of receding wet areas in the survey area. By late summer, a larger part of the survey area was drying during the day and rewetting during the night.

From visual examination for abnormalities and external parasites, swab sampling for $B d$, and pathological assessments on voucher specimens, the western toad population appears healthy. The body mass index generally increases with age. Because of the high number of captures during the mark-recapture sessions, gender delineation was not made. Therefore, the high variance in body mass index (fig. 37) could be partly attributed to differences between gender and reproductive status (gravid females generally have a higher mass to SVL ratio than males or spent females). These results provide a baseline with which to compare future data, and can be used to evaluate deviations and trends in body condition. The five individuals having abnormalities that were observed is consistent with that of 0-2 percent typical of a normal population. No swab samples tested positive for the presence of $B d$, but testing could be repeated in the future and include real-time PCR analysis, as it may detect presence, even when visible signs are absent, thus enabling early detection of this deadly fungus. All captures were visually inspected for the presence of external parasites, and none were detected. Lastly, all western toads (tadpoles and metamorphs) examined by the USGS NWHC were considered healthy. Three of the larvae analyzed carried the myxosporean parasites (Myxidium spp.) in the gall bladder, and one indicated an atresia (closing) of the spiracle opening (table 22) - both conditions appear to be isolated incidents and do not signify an epidemic.

The study by Crayon (1999) concluded that water availability was a primary factor affecting the western toad population in the Darwin Falls area (fig. 2), and occupancy is higher in areas where water is available. In 2006, more animals were in the upper half of the study area, where perennial flow occurs in Darwin Wash (fig. 6), than in the lower half where flow is intermittent. As discussed in the "Hydrogeological Results and Discussion" section of Chapter B of this report, base flow in Darwin Wash (fig. 2) is variable (fig. 19; table 11); however, measured precipitation data are not available near the study site to develop a reliable relation between precipitation and base flow. Successive years of below average precipitation could negatively affect the western toad population along Darwin Wash by decreasing the riparian habitat reach. Furthermore, the availability of water in the lower reaches of Darwin Wash may be affected by the trend of gradually increasing temperature minimums in the Mojave Desert (figs. 1, 2, and 34) since about 1950. Availability of water in the lower reaches is expected to be sensitive to increasing evapotranspiration caused by the increasing air-temperature minimums. Water consumption by salt cedar (Tamarix ramosissima) also reduces base flow in Darwin Wash (fig. 2). The NPS has implemented removal efforts to manage this highly invasive species. 


\section{Source, Discharge, and Chemical Characteristics of Selected Springs and Endemic Anuran Species, Mojave Network Parks}

The water-quality data presented in the "Hydrogeological Results and Discussion" section of Chapter B of this report indicate that arsenic (As) concentrations are high (greater than 30 micrograms per liter $[\mu \mathrm{g} / \mathrm{L}]$; table 5) and salinity is moderate (residue on evaporation at 180 degrees Celcius $\left[{ }^{\circ} \mathrm{C}\right.$; $\mathrm{ROE}$ ] greater than 400 milligrams per liter $[\mathrm{mg} / \mathrm{L}]$; table 3 ) in Darwin Wash (fig. 2). These constituents are derived from natural sources in the drainage basin and are likely to have always had similar concentrations, given that the groundwater discharge is thousands of years old (table 6). Therefore, it is likely that endemic anuran populations have adapted to these environmental conditions.

Habitat degradation at Darwin Falls (fig. 2) could be negatively affecting the western toad population in the study area. Visitor effects from trash, swimming, and heavy foot traffic are readily evident throughout the wetted reach, and they can lead to egg mass and tadpole mortality, and impaired water quality that also might affect the larval stages.

\section{Piute Spring, Mojave National Preserve}

The red-spotted toad was present throughout Piute Creek (fig. 9), where previous studies (McGurty, 1977; L. Ulmer, unpub. data, 1983; Hazard and Rotenberry, 1996; Persons and Nowak, 2007) also documented its presence. The population estimate of 1,153 adults (95-percent CI of 935-1,503) obtained from the 2006 mark-recapture surveys (table 21) provides a baseline for future comparisons. The data indicate that the current population is large with all age classes represented as early in the season as April. Furthermore, the presence of metamorphs in April indicates that breeding began in February.

In September of 2004, a high intensity fire occurred throughout the lower reach of the riparian habitat and made a few up-slope runs into the upland desert scrub community (Dingman, 2004). Surveys for this study began about 8 months after the fire. At that time, nearly all the vegetation in the lower part of the wetted channel had been burned away; however, the upper part near Piute Spring (fig. 7) escaped the fire and remained thick with vegetation. Toads were observed only sporadically in 2005 surveys because of the dense vegetation cover within the wetted channel. A flash flood that swept through the entire canyon soon after the last survey in 2005 scoured out most of the remaining vegetation and considerable sediment. As a result, the survey reach was extended upstream in 2006, and toads were present in high numbers throughout the entire wetted reach all the way upstream to Piute Spring (fig. 7).

Reproduction of the red-spotted toad at Piute Creek (fig. 9) appears to be continuous from April through July. This is advantageous and typical of desert amphibian species with a perennial source of water.

In general, the red-spotted toads in the Piute Spring study area appear healthy. The relation between body mass and SVL for toads at Piute (figs. 7 and 38) exhibits greatest variation within the adult life stage, presumably because data regarding gender and breeding (before or after) status were not obtained. These data provide a baseline for future comparisons. No toads tested positive for the presence of $B d$ in the population sampled. Only three toads carried external parasites, but none in high numbers.

Visual inspection of red-spotted toads revealed a higher than normal-approximately 5 percent-rate of abnormalities. A 0-2 percent rate for morphological abnormalities because of mutation, trauma, and developmental errors is usually present in amphibian populations (Tyler, 1998; Ouellet, 2000). An earlier survey done in the Piute Spring area (fig. 7; L. Ulmer, Mojave National Preserve, unpub. data, 1983) documented abnormalities in 4 out of 202 toads (2 percent) captured during a 3-month period. Surveys by McGurty (1977), Hazard and Rotenberry (1996), and Persons and Nowak (2007) failed to detect any abnormalities, although the focus of their studies was to determine presence of toads rather than health of populations. Later research within the eastern Mojave Desert (fig. 1) by Bradford and others (2003) determined an average abnormality rate across that entire study area (95 sites) of 1.83 percent.

The interaction of several environmental factors makes it difficult to establish a clear cause-and-effect association for the high incidence of abnormalities in this population. Malformed anurans have been reported with increasing frequency in several parts of North America, and research indicates that the following three main factors may act, either alone or together, to cause anuran abnormalities: parasites, chemical contaminants, and ultraviolet B shortwave rays (UVB) radiation (Ouellet and others, 1997; Kiesecker and others, 2004).

The presence of trematode larval stages in frogs has received increasing attention during the past decade with the advancement of a hypothesis that encysted larvae of one or several flukes may be partly responsible for increased occurrences of malformed frogs in North America (Johnson and others, 1999). Additionally, recent findings have linked high frequencies of limb deformities to infection with a trematode parsite (Psilostominae ondatrae) that make them more susceptible to parasites, predation, and injury (Sessions and Ruth, 1990; Johnson and others, 1999). Some have suggested, however, that the role of trematode parasites in causing abnormalities has been overemphasized (Johnson and others, 2004; Ankley and others, 2005).

Higher incidences of abnormalities also are associated with agricultural areas (Ouellet and others, 1997) where pesticides and herbicides containing xenobiotics are located (Rand and others, 1995; Diana and Beasley, 1998). The herbicide Garlon (triclopyr), a known endocrine disruptor, was used at Piute Canyon (fig. 9) for salt cedar removal; however, pesticides were not detected above laboratory reporting levels (LRLs) in samples collected for this study (table 9).

Nitrate $\left(\mathrm{NO}_{3}\right)$ is a possible endocrine disrupter known to cause changes in the physiology and development of organisms (Guillette and Edwards, 2005). Concentrations of $\mathrm{NO}_{3}$ in samples collected from the Piute Spring study area 
(fig. 7) ranged from about $2-4 \mathrm{mg} / \mathrm{L}$ as nitrogen (N; table 4 ). Although $\mathrm{NO}_{3}$ concentrations are well below the drinking water regulation threshold $(10 \mathrm{mg} / \mathrm{L})$, similar concentrations have been determined to be lethal and cause developmental anomalies in amphibians in a laboratory setting (Rouse and others, 1999). Elevated N concentrations are usually from agricultural and urban sources in a drainage basin, but can also be from atmospheric deposition from precipitation (Rouse and others, 1999). The fire at Piute Creek (fig. 9) may have contributed to a temporary increase in $\mathrm{NO}_{3}$ by diminishing the vegetation, which would have absorbed and used the $\mathrm{N}$ deposited into the system. Thus, it is possible that changes in the hydrological system with respect to $\mathrm{NO}_{3}$ could be a factor in anuran health; however, future surveys and analyses would be needed to determine if $\mathrm{NO}_{3}$ is a factor in the observed higher than normal rate of abnormalities at Piute Creek (fig. 9).

Finally, UVB radiation also has been indicated to cause abnormalities in anurans (Blaustein and others, 1997; Fite and others, 1998). This could be a factor at Piute Creek (fig. 9) because much of the canopy cover burned in the 2004 fire, leaving the stream channel exposed to higher UVB radiation. Future surveys would be needed to confirm if UVB radiation is a factor in the observed higher than normal rate of abnormalities at Piute Creek (fig. 9).

\section{Fortynine Palms Oasis, Joshua Tree National Park}

Detection of reproductive activity for the red-spotted toad and the California treefrog at Fortynine Palms Oasis (fig. 12) was difficult. Previous studies at Fortynine Palms Oasis indicated that red-spotted toads delay the onset of their breeding until after treefrogs and are still breeding into late September (Welbourn and Loomis, 1975). The data collected from this study, though few numbers were observed, seem to corroborate these findings. California treefrog tadpoles were detected in April, May, and June, and those in June were in the late stage of development. Red-spotted toad tadpoles were only detected during the last survey in June, and all were within the early stage of development.

The results of field work completed by this study indicated that 2.7 percent of 153 captured toads and a single treefrog had abnormalities. These data are consistent with a normal 0-2 percent rate for morphological abnormalities due to mutation, trauma, and developmental errors (Tyler, 1998; Ouellet, 2000).

In a 1969-71 survey, chiggers were documented in treefrogs and toads; 98.9 percent of treefrogs examined had ectoparasites, with an average of 21 chiggers embedded in their skin (Welbourn and Loomis, 1975). In 2006, about 58 percent of treefrog captures had chiggers, with an average of about 21 chiggers per frog. For toads, the 1969-71 survey documented 41 percent of all captures carried an average of 8 chiggers, whereas in 2006 ( 7 visits), only 5.4 percent of the toads carried an average of 9 chiggers per animal. For both species, this represents a large decrease in the number of animals hosting these parasites, yet the mean number of parasites per animal remained virtually unchanged. Little data exist on the effects of chiggers on anurans, but previous studies with the Ozark zigzag salamander (Plethodon angusticlavius) indicated that males with a higher chigger load incur many ecological burdens including being less successful in territorial disputes (Maksimowich and Mathis, 2000).

No toads or frogs tested positive for viruses, bacteria, histological abnormalities, or $B d$ (table 22). The commonly present myxosporean parasite (Myxidium spp.; McAllister and Trauth, 1995), was detected in the gall bladder of a treefrog larva (table 22). Repeat testing for $B d$ in future studies could allow detection of the fungus before visible signs are present, thus permitting early detection of this deadly fungus.

In the Joshua Tree National Park (fig. 1), the California treefrog now occupies only three of the seven historically occupied drainages. Population estimates in 1969-71 by Welbourn and Loomis (1975) from the same site as this study estimated California treefrogs at 288 and red-spotted toads at 300 individuals. Current (2006) population estimates are approximately 50 percent lower than the 1969-71 estimates (table 21). Park personnel are proposing projects to determine if reintroduction of treefrogs to their historical locations within Joshua Tree National Park is a viable option for increasing populations. According to Phillipsen and Metcalf (2009), geographical isolation of this species at Joshua Tree National Park (fig. 1) is reflected in the species' molecular genetics; therefore, reintroduction from current (2006) populations (table 21) could be used to repopulate the historical sites.

The availability of water at Fortynine Palms Oasis (fig. 12) might be a factor in endemic anuran population and health. Because the Fortynine Palms Oasis drainage basin (fig. 12) is a fractured-rock system with a small amount of groundwater storage, the natural spring discharge (base flow) from this basin is highly variable and is closely related to recent precipitation (fig. 18C). Tritium-helium-3 $\left({ }^{3} \mathrm{H}-{ }^{3} \mathrm{He}\right)$ dating of the spring discharge indicates a groundwater age of less than 2 years (table 6). The combination of young age and limited groundwater storage makes Fortynine Palms Oasis (fig. 12) sensitive to climate variability. Hydrological fluctuations, such as the floods recorded during the current study, also might affect endemic anuran population. Future hydrological studies and endemic anuran surveys would be needed to determine the effects of climate variability on water availability, and endemic anuran population and health at Fortynine Palms Oasis (fig. 12). 
This page intentionally left blank. 


\section{Chapter D. Summary and Conclusions}

\author{
By Roy A. Schroeder, Elizabeth Gallegos, Gregory A. \\ Smith, Peter Martin, and Robert N. Fisher
}

Hydrological and biological investigations were done during 2005 and 2006 in cooperation with the U.S. National Park Service at Darwin Falls in Death Valley National Park, Piute Spring in Mojave National Preserve, and Fortynine Palms Oasis in Joshua Tree National Park where discharge from springs or groundwater seeps sustains rare perennial streams in the otherwise arid environment of the Mojave Desert in which surface water is scarce and usually ephemeral. The study collected data on water quantity (discharge), temperature, water quality, and endemic anuran (frog and toad) populations and their health. In addition, a single survey of endemic anuran populations and their health was completed at Rattlesnake Canyon in the Joshua Tree National Park. Results from this study were compared to historical data, and can provide a baseline for future hydrological and biological investigations to evaluate health and sustainability of the resource as well as its response to changing climate and increases in human use.

Attempts to obtain continuous water depth (a proxy for flow) and temperature were unsuccessful, as monitoring probes were destroyed by flash floods at all three locations during the 2-year period of this study. Continuous historical discharge data exist at only one of the three sites, Darwin Wash, where the U.S. Geological Survey (USGS) operated a gaging station from 1962 to 1989, and where the record indicates flood events occur every few years. In fact, the gage height at this gaging station reached nearly 2.6 meters (m) during a flood in 1969 when discharge exceeded base flow by a factor of 10,000, which is far greater than the flood event that occurred during the time of this study. Apparently the physical devastation that accompanies the frequent flash floods that recur every few years at all three study areas does not result in long-term damage to the flora and fauna.

Declining annual precipitation during the second year of this study (2006) appears to be accompanied by a decrease in discharge, although quantifying this correlation would require the collection of monthly precipitation and discharge data for at least 5 years. Water quality does not appear to be sensitive to trends in precipitation or seasonality in the Darwin Falls and Piute Spring study areas; however, it is sensitive in Fortynine Palms Oasis, where salinity increased by more than 10 percent for the 2 years of this study. Such a rapid response is consistent with the comparatively short travel time of less than 2 years from recharge to discharge (travel time was derived from tritium-helium-3 $\left({ }^{3} \mathrm{H}-{ }^{3} \mathrm{He}\right)$ dating), and is in marked contrast to radiocarbon ages estimated to be about 3,000 years for the water at Darwin Spring and nearly 7,000 years at Piute Spring.
Stable-isotope ratios measured in water samples from this study were used in conjunction with similar published data from a network of precipitation stations to interpret an average altitude of recharge of 2,348 m for Darwin Spring (about 1,415 m higher than Darwin Spring); 1,668 m for Piute Spring (about $766 \mathrm{~m}$ higher than Piute Spring); and 1,400 $\mathrm{m}$ for the Upper Pool at Fortynine Palms Oasis (about 543 m higher than the Upper Pool). These estimated average altitudes of recharge imply that most of the recharge occurs along Coso Peak in the Coso Ranges and Maturango Peak in the Argus Ranges for Darwin Spring, along the flanks of the New York Mountains in the northwestern part of the Lanfair Valley for Piute Spring, and near the summit of Queen Mountain for Fortynine Palms Oasis. When the area above this altitude is multiplied by the modified Parameter Regression on Independent Slopes Model (PRISM) mean annual precipitation, it yields annual recharge rates that exceed base flow by about 10 times in Darwin Wash, about 100 times in Piute Creek, and about 1,000 times in Fortynine Palms Oasis drainage basins because much of the precipitation is likely lost as evapotranspiration and runoff.

No discernible differences in relative concentration of major ions or trace elements was recorded between the different sampling events, indicating that the source of water to the study areas did not change substantially during the 2-year study. Piute Creek is the only location for the three study areas that has historical water-quality data, and comparison indicates little or no change in concentration of most parameters from 1981 to this study 25 years later. The only exception is nitrate $\left(\mathrm{NO}_{3}\right)$, for which concentrations increased from about 1 milligram per liter $(\mathrm{mg} / \mathrm{L})$ as nitrogen $(\mathrm{N})$ in available historical data to about $2.5 \mathrm{mg} / \mathrm{L}$ in this study in the aftermath of the fire and subsequent flood. Increased chemical concentrations in streams, especially for nitrate, that persists for as many as several years have been documented elsewhere in response to removal of vegetation in a drainage basin. This study's finding that chemical composition (relative concentration of major ions) and strontium ( $\mathrm{Sr}$ ) isotope ratios exhibited minimal change in successive samples from all three study areas is an indication that groundwater flowpaths within each study area intercept the same geologic units, irrespective of changes in season and annual precipitation.

Xenobiotic compounds and trace elements are the only chemical constituents that potentially could cause environmental effects in riparian reaches of the three study areas. However, pesticides were not detected above laboratory reporting levels in single samples from either Fortynine Palms Oasis, which is downwind of agricultural areas, or in Piute Creek, where triclopyr was sprayed for control of salt cedar after the fire and flood denuded its riparian habitat. The only trace elements that were detected at high concentrations were uranium (U) at Fortynine Palms Oasis (about 100 micrograms per liter $[\mu \mathrm{g} / \mathrm{L}]$ ), and arsenic (As) at Darwin Falls (about $30 \mu \mathrm{g} / \mathrm{L})$ and to a lesser extent at Piute Creek (7-8 $\mu \mathrm{g} / \mathrm{L})$. Both trace elements are thought not to have deleterious effects on local flora and fauna insofar as they are derived from natural sources in each drainage basin, and therefore are likely to have existed at the same high level historically. 


\section{Source, Discharge, and Chemical Characteristics of Selected Springs and Endemic Anuran Species, Mojave Network Parks}

Anuran surveys were done for the western toad (Anaxyrus boreas) at Darwin Wash, red-spotted toad (Anaxyrus punctatus) at Piute Creek, and red-spotted toad and California treefrog (Pseudacris cadaverina) at Fortynine Palms Oasis. The adult western toad population was estimated to be 381 (95-percent confidence interval [CI] of 314-482) in the entire 1.25-kilometer $(\mathrm{km})$ reach from the base of Darwin Falls to where Darwin Wash disappears beneath the sand. Comparison to 180 adults (95-percent CI of 128-300) reported for a 1999 survey done in only the lower half of Darwin Wash indicates little or no change in total population between the two surveys. Recaptures in 2006 of adults tagged in 1997-99 would have to be at least 9 to 11.5 years old, which supports published statements attesting to the long life span of this species elsewhere. Red-spotted toads were present throughout Piute Creek where the 1,153 adults (95-percent CI of 9351,503 ) in 2006 represent their first enumeration in this stream. California treefrogs existed in seven separate drainages in Joshua Tree National Park during the 1960s, but are now present in only three. The estimated adult population of 109 (95-percent CI of 90-139) in 2006 from this study at Fortynine Palms Oasis compares to 288 reported in a 1969-71 study and mirrors a similar decline from 300 to 155 (95-percent CI of 113-247) in red-spotted toads at this site. A longer period and more frequent monitoring would be needed to determine whether this trend is real or merely cyclical.

Additional methods used to assess the overall health of endemic anuran populations included examining the bodymass index of captures, swab testing for the chytrid fungus Bactrochochytrium dendrobatidis $(B d)$ fungus, visual inspection for external parasites and abnormalities, and general pathological laboratory evaluations on a small number of individuals. Results from these methods generally indicate healthy populations with the notable exception of elevated abnormalities in red-spotted toads at Piute Creek, where about 5 percent of the observed animals had abnormalities in 2006, which exceeds the accepted baseline of a natural abnormality rate of 2 percent. The cause of this increase is unknown, although a synergistic effect with increased exposure to ultraviolet B shortwave rays (UVB) radiation in the immediate aftermath of the 2004 wildfire is plausible. Future surveys would be needed to confirm if UVB radiation is a factor in the observed higher than normal rate of abnormalities at Piute Creek. The chytrid fungus, $B d$, also was present in red-spotted toads surveyed from Piute Creek for this study. This study determined that about 58 percent of treefrogs at Fortynine Palms Oasis were infested with an average of 21.2 chiggers per individual in 2006 compared to about 99 percent of treefrogs infested with an average of 21.4 chiggers per individual in a 1969-71 survey. For red-spotted toads, the 1969-71 survey documented 41 percent of all captures carried an average of 8 chiggers per individual compared to only about 5 percent with an average of 9 chiggers per individual in 2006. For both species there was a significant decline in the percentage of animals hosting the parasite although the average number of parasites per infested animal remained the same.
It would be necessary to periodically repeat studies similar to this one to assess effectiveness of protecting the resource and to discern any possible effects of climatic changes. However, such studies at these remote sites are too labor intensive and expensive to be repeated on anything shorter than decadal time scales. The results of this study indicate that significant changes in aquatic chemical concentrations are unlikely; therefore, only limited resampling is advisable. Installation of temporary equipment to obtain continuous discharge or temperature data is not practical given the likelihood of destructive flood events. Permanent gaging stations, such as the one formerly installed on Darwin Wash, would provide valuable information on flood frequency and intensity, and on response to climate trends. The only hydrologically suitable location for installation of a permanent gaging station on Piute Creek is at a partially destroyed concrete dam where any stream-gaging structure would again eventually be destroyed by flash floods. No suitable permanent gaging site exists at Fortynine Palms Oasis because of the large boulders and fractures in the terrain. Future endemic anuran population surveys that acquire not only population counts and recruitment statistics, but also ancillary health information such as tests for pathogens and deformities that were incorporated by this study would be needed to add to the understanding of these species.

The three study areas in the Mojave Network Parks exhibit different patterns of trends in the indicator amphibians. They also differ in their chemical and environmental conditions. To the extent that climate change affects water availability, the response would be expected to be observed sooner at Fortynine Palms Oasis than at Darwin Falls and Piute Spring because of its much younger recharge, so this site can serve as a sentinel for other similar habitats in the desert landscape. Obtaining a greater understanding of why the endemic anuran populations are declining at Fortynine Palms Oasis could be a first step in better understanding how these systems operate and respond to environmental stresses. Because of their long recharge times, the Darwin Falls and Piute Spring study areas are more buffered from changes in precipitation; therefore, management at these and similar sites is more dependent on understanding the role played by invasive species, disease, pathogens, water use, and other environmental drivers.

Hydrological differences and frequency of human use indicate the need for somewhat different strategies in each location to protect the resource. Limiting extensive human development, such as mining and water withdrawal, above the recharge area could prevent long-term effects from developing, especially at Fortynine Palms Oasis where the time for recharge to reach the spring is brief. Presumably this also renders Fortynine Palms Oasis much more sensitive to climate change than are the other two springs. Anticipated additional groundwater development of the Morongo Groundwater Basin in response to increasing population will have no effect on discharge at Fortynine Palms Oasis because the spring is situated more than $120 \mathrm{~m}$ above the current 
(2008) water table in the basin. Population in the vicinity of the other two springs is sparse. Human traffic at lower altitudes likely represents the greatest threat for short-term effects to the riparian habitat at all three locations. In fact, a wildfire caused by hikers in 2004 severely burned much of the riparian habitat along Piute Creek.

Desert springs are extremely important environments within harsh landscapes, and hence are by their very nature sensitive to minor fluctuations in environmental conditions. Even within protected lands, they are subject to degradation, and their role in maintaining biodiversity is being constantly challenged. In this study, by focusing on three indicator sites across three desert parks, we were better able to understand the potential drivers of change in conditions at these sites, and to determine baseline biological, hydrological, and chemical conditions. Amphibian populations were the indicators for biological conditions, and it is apparent from this study that each site has had significant changes during the last few decades in its populations of inhabiting endemic anurans. At Darwin Falls, there has been a change in species present from the beginning of the 19th century when it was occupied only by the red-spotted toad, to the 1970s when hybridization was first reported between this species and the putative invasive western toad, and then to 2005 when red-spotted toads are no longer present. This change is because of the introduction of the western toad to this site and not because of change in environmental conditions of the spring. At Piute Spring, there continues to be a robust population of red-spotted toads, although they were determined to have an increased number of deformities compared to other areas in the Mojave Desert. This elevated deformity level (approximately 5 percent) is not easily explained and probably is linked to some environmental stressor not yet evaluated. Previous studies at this site during the past 30 years did not document this observation. At Fortynine Palms Oasis, the populations of red-spotted toads and California treefrogs have declined by approximately 50 percent during the last 35 years. Data do not exist to determine if this is possibly because of habitat shrinkage (a smaller suitable area for them to occupy) or to other unknown environmental drivers. The populations of external parasites that depend on these species at this site also have declined. Spring discharge at Fortynine Palms Oasis is driven by comparatively recent rainfall and thus is more sensitive to hydrological changes than are the other two sites. It also is possible that increased fire frequency at the Joshua Tree National Park may play a role in increasing sedimentation and reducing available aquatic habitat for endemic anurans. Available biological data indicate that all three sites have changed biologically since the earliest studies; therefore, subsequent surveys will help monitor future changes. The changing biological conditions documented at these sites indicate the importance of collecting similar baseline data at other remote springs and wetlands in these large park landscapes, as it is apparent that, despite being well protected through legislation, the biological conditions of many of these sensitive habitats continue to be degraded.

\section{References Cited}

Aeschbach-Hertig, W., Peeters, F., Beyerle, U., and Kipfer, R., 1999, Interpretation of dissolved atmospheric noble gases in natural waters: Water Resources Research, v. 35, no. 9, p. 2779-2792.

Aeschbach-Hertig, W., Peeters, F., Beyerle, U., and Kipfer, R., 2000, Paleotemperature reconstruction from noble gases in groundwater taking into account equilibrium with entrapped air: Nature, v. 405, p. 1040-1044.

Anderson, R.O., and Gutreuter, S.J., 1983, Length, weight, and associated structural indices, in Nielson, L.A., and Johnson, D.L., eds., Fisheries techniques: Bethesda, Md., American Fisheries Society, p. 283-300.

Ankley, G.T., Black, M.C., Garrie, J., Hutchinson, T., and Iguchi, T., 2005, A framework for assessing the hazard of pharmaceutical materials to aquatic species, in Williams, R.T., ed., Human pharmaceuticals - Assessing the impacts on aquatic ecosystems: Pensacola, Fla., Society for Environmental Toxicology and Contaminants Press, p. 183-238.

Bailey, R.G., 1995, Description of the ecoregions of the United States, 2d edition (1:7,500,000 map): Washington D.C., Miscellaneous Publication 1391, U.S. Forest Service.

Bancila, R.I., Hartel, T., Plaiasu, R., Smets, J., and Cogalniceanu, D., 2010, Comparing three body condition indices in amphibians - A case study of yellow-bellied toad Bombina variegate: Amphibia-Reptilia, v. 31, p. 558-562.

Baron, J.S., Poff, N.L., Angermeier, P.L., Dahm, C.N., Gleick, P.H., Hairston, N.G., Jr., Jackson, R.B., Johnston, C.A., Richter, B.D., and Steinman, A.D., 2002, Meeting ecological and societal needs for freshwater: Ecological Applications, v. 12, p. 1247-1260.

Bartelt, P.E., 2000, A biophysical analysis of habitat selection in western toads (Bufo boreas) in southeastern Idaho: Pocatello, Idaho, Ph.D. dissertation, Idaho State University, [n.p.]

Bedinger, M.S., and Sargent, K.A., 1989, Studies of geology and hydrology in the Basin and Range Province, Southwestern United States, for isolation of high-level radioactive waste-characterization of the Death Valley Region, Nevada and California: U.S. Geological Survey Professional Paper $1370-\mathrm{F}, 49 \mathrm{p}$.

Berenbrock, Charles, and Schroeder, R.A., 1994, Groundwater flow and quality, and geochemical processes, in Indian Wells Valley, Kern, Inyo, and San Bernardino Counties, California, 1987-88: U.S. Geological Survey WaterResources Investigations Report 93-4003, 59 p., 1 pl. 
Berger, L., Speare, R., Daszak, P., Green, D., and others, 1998, Chytridiomycosis causes amphibian mortality associated with population declines in the rain forests of Australia and Central America: Proceedings of the National Academy of Sciences, v. 95 , no. 15 , p. $9031-9036$.

Berrill, M., Bertram, S., McGillivray, L., Kolohon, M., and Pauli, B, 1994, Effects of low concentrations of forest-use pesticides on frog embryos and tadpoles: Environmental Toxicology and Chemistry, v. 13, p. 657-664.

Blaustein, A.R., Kiesecker, J.M., Chivers, D.P., and Anthony, R.G., 1997, Ambient UV-B radiation causes deformities in amphibian embryos: Proceedings of the National Academy of Sciences, v. 94, no. 25, p. 13,735-13,737.

Borman, F.H., and Likens, G.E., 1970, The nutrient cycles of an ecosystem: Scientific American, v. 223, no. 4, p. 92-101.

Bortugno, E.J., and Spittler, T.E., 1986, Geologic map of the San Bernardino quadrangle: Department of Conservation, Division of Mines and Geology, Regional Geologic Map Series, no. 3a (Geology), scale 1:250,000.

Bosch, J., Martinez-Solano, I., and Garcia-Paris, M., 2001, Evidence of a chytrid fungus infection involved in the decline of the common midwife toad (Alytes obstetricans) in protected areas of central Spain: Biological Conservation, v. 97 , p. 331-337.

Boyle, D.G., Boyle, D.B., Olsen, V., Morgan, A.T., and Hyatt, A.D., 2004, Rapid quantitative detection of chytridiomycosis (Batrachochytrium dendrobatidis) in amphibian samples using real-time Taqman PCR assay: Diseases of Aquatic Organisms, v. 60, p. 141-148.

Bradford, D.F., Neale, A.C., Nash, M.S., Sada, D.W., and Jaeger, J.R., 2003, Habitat patch occupancy by toads (Bufo punctatus) in a naturally fragmented desert landscape: Ecology, v. 84, p. 1,012-1,023.

Brater, E.F., 1940, The unit hydrograph principle applied to small watersheds: Transactions of the American Society of Civil Engineers, v. 105, p. 1,154-1,178.

Bredehoeft, J.D., and Durbin, T.J., 2009, Ground water development-The time to full capture problem: Ground Water, v. 47 , no. 4 , p. $506-514$.

Bullen, T.D., Krabbenhoft, D.P., and Kendall, Carol, 1996, Kinetic and mineralogic controls on the evolution of groundwater chemistry and ${ }^{87} \mathrm{Sr} /{ }^{86} \mathrm{Sr}$ in a sandy silicate aquifer, northern Wisconsin, USA: Geochimica et Cosmochimica Acta, v. 60, p. 1,807-1,821.

Campbell, J.B., 1970, Hibernacula of a population of Bufo boreas boreas, in the Colorado Front Range: Journal of Herpetology, v. 4, p. 83-85.
Campbell, J.B., 1976, Environmental controls on boreal toad populations in the San Juan Mountains, in Steinhoff, H.W., and Ives, J.D., eds., Final Report, San Juan Ecology Project: Fort Collins, Colo., Colorado State University Publications, p. 289-295.

Carey, Cynthia., 1976, Thermal physiology and energetics of boreal toads, Bufo boreas boreas: Ann Arbor, Mich., Ph.D. dissertation, University of Michigan, [n.p.]

Carey, C.N., Heyer, W.R., Wilkinson, J., Alford, R.A., Arntzen, J.W., Halliday, T., Hungerford, L., Lips, K.R., Middleton, E.M., Orchard, S.A., and Rand, A.S., 2001, Amphibian declines and environmental change-Use of remote sensing data to identify environmental correlates: Conservation Biology, v. 15, p. 903-913.

Chung-MacCoubrey, A. L., Truitt, R.E., Caudill, C.C., Rodhouse, T.J., Irvine, K.M., Siderius, J.R., and Chang, V.K., 2008, Mojave Desert Network vital signs monitoring plan: Fort Collins, Colo., NPS-MOJN-NRR-2008-057 National Park Service, 126 p.

Conners, T., and Covington, S., 2004, Death Valley National Park geologic resources management issues scoping summary: National Park Service, Geologic Resources Division, $17 \mathrm{p}$.

Coplen, T.B., 1994, Reporting of stable hydrogen, carbon, and oxygen isotopic abundances: Pure and Applied Chemistry, v. 66, p. $273-276$.

Coplen, T.B., Wildman, J.D., and Chen, J., 1991, Improvements in the gaseous hydrogen-water equilibrium technique for hydrogen isotope analysis: Analytical Chemistry, v. 63, p. $910-912$.

Corn, P.S., 2005, Climate change and amphibians: Animal Biodiversity and Conservation, v. 28, p. 57-65.

Covington, S., 2003, Mojave National Preserve geologic resources management issues scoping summary: National Park Service, Geologic Resources Division, 11 p.

Craig, Harmon, 1961a, Isotopic variation in meteoric waters: Science, v. 133, p. 1702-1703.

Craig, Harmon, 1961b, Standard for reporting concentrations of deuterium and oxygen-18 in natural waters: Science, v. 133, p. 1833-1834.

Crayon, J.J., 1999, Habitat use by western toads (Bufo boreas) in the Darwin Falls Wash, preliminary report: Death Valley, Calif., Death Valley National Park Resource Management Division, $14 \mathrm{p}$. 
Daly, Christopher, Gibson, W.P., Doggett, M.K., Smith, J.I., and Taylor, G.H., 2004, Up-to-date monthly climate maps for the conterminous United States: AMS Conference on Applied Climatology, 14th, Seattle, Wash., January 13-16, 2004, American Meteorological Society, combined preprints, paper P5.1, CD-ROM.

Dansgaard, Willi, 1964, Stable isotopes in precipitation: Tellus, v. 16, p. 436-469.

Daszak, P., Cunningham, A., and Hyatt, A., 2003, Infectious disease and amphibian population declines: Diversity and Distributions, v. 9, p. 141-150.

Davis, S.N., Whittemore, D.O., Fahryka-Martin, J., 1998, Uses of chloride-bromide ratios in studies of potable water: Ground Water, v. 36, p. 338-350.

Dayton, G.H., and Fitzgerald, L.A., 2006, Habitat suitability models for desert amphibians: Biological Conservation, v. 132 , p. $40-49$.

Death Valley National Park, National Park Service, 2006, Weather and Climate Death Valley National Park: National Park Service, rev 7-06, accessed November 5, 2014, at http://www.nps.gov/deva/planyourvisit/upload/Weather $\% 20$ and $\% 20$ Climate.pdf.

Dettinger, M.D., and Earman, S., 2007, Western ground water and climate change-Pivotal to supply sustainability or vulnerable in its own right?: National Ground Water Association Newsletter, Ground Water News and Views, v. 4, p. 4-5.

Diana, S.G., and Beasley, V.R., 1998, Amphibian toxicology, in Lanoo, M.J., ed., Status and conservation of midwestern amphibians: Iowa City, Iowa, University of Iowa Press, $\mathrm{p}$. 266-277.

Dingman, S., 2004, Resource advisor report, Mojave National Preserve, Piute fire: Barstow Calif., Mojave National Preserve, $4 \mathrm{p}$.

Donahue, D.J., Linick, T.W., and Jull, A.J.T., 1990, Ratio and background corrections for accelerator mass spectrometry radiocarbon measurements: Radiocarbon, v. 32, p. 135-142.

Durkin, Patrick, and Diamond, Gary, 2002, Neurotoxicity, immunotoxicity, and endocrine disruption with specific commentary on glyphosate, trichlopyr, and hexazinone: U.S. Department of Agriculture Forest Service, Syracuse Environmental Research Associates, Inc., TR 01-43-0804a, $55 \mathrm{p}$.

Eaton, G.F., Hudson, G.B., and Moran, J.E., 2004, Tritiumhelium-3 age-dating of groundwater in the Livermore Valley of California: American Chemical Society Symposium Series no. 868, p. 235-245.
Epstein, S., and Mayeda, T., 1953, Variation of O-18 content of water from natural sources: Geochimica Cosmochimica Acta, v. 4, p. 213-224.

Ervin, E.L., Lannoo, M.J., Gallant, A.L., Nanjappa, P., Blackburn, L., and Hendricks, R., 2005, Introduction-Part twoPseudacris cadaverina species account, in Lannoo, M.J., ed., Amphibian Declines - The Conservation Status of United States Species: Berkeley, Calif., University of California Press, p. 351-380.

Faires, L.M., 1993, Methods of analysis by the U.S. Geological Survey National Water Quality Laboratory - determination of metals in water by inductively coupled plasma-mass spectrometry: U.S. Geological Survey Open-File Report 92-634, 28 p.

Feder, J.H., 1979, Natural hybridization and genetic divergence between the toads Bufo boreas and Bufo punctatus: Evolution, v. 33, p. 1089-1097.

Fellers, G.M., Launer, A.E., Rathbun, G., Bobzien, S., Alvarez, J., Sterner, D., Seymour, R.B., and Westphal, M., 2001, Overwintering tadpoles in the California red-legged frog (Rana aurora draytonii): Herpetological Review, v. 35, p. 163.

Fishman, M.J., 1993, Methods of analysis by the U.S. Geological Survey National Water Quality Laboratory-Determination of inorganic and organic constituents in water and fluvial sediments: U.S. Geological Survey Open-File Report 93-125, $217 \mathrm{p}$.

Fishman, M.J., and Friedman, L.C., 1989, Methods for determination of inorganic substances in water and fluvial sediments: U.S. Geological Survey Techniques of WaterResources Investigations, book 5, chap. A1, 545 p.

Fite, K.V., Blaustein, A.R., Bengston, L., and Hewitt, H.E., 1998, Evidence of retinal light damage in Rana cascadae: a declining amphibian species: Copeia, v. 1998, no. 4, p. 906-914.

Flint, A.L., and Flint, L.E., 2007a, Application of the basin characterization model to estimate in-place recharge and runoff potential in the Basin and Range carbonate-rock aquifer system, White Pine County, Nevada, and adjacent areas in Nevada and Utah: U.S. Geological Survey Scientific Investigations Report 2007-5099, 20 p.

Flint, L.E., and Flint, A.L., 2007b, Regional analysis of ground-water recharge, in Stonestrom, D.A., Constantz, J., Ferré, T.P.A., and Leake, S.A., eds., Ground-water recharge in the arid and semiarid southwestern United States: U.S. Geological Survey Professional Paper 1703, p. 29-59. 
Flint, L.E., Flint, A.L., Thorne, J.H, and Boynton, Ryan, 2013, Fine-scale hydrologic modeling for regional landscape applications - The California Basin characterization model development and performance: Ecological Processes, v. 2, $21 \mathrm{p}$.

Flint, L.E., and Martin, Peter, eds., with contributions by Brandt, Justin, Christensen, A.H., Flint, A.L., Flint, L.E., Hevesi, J.A., Jachens, Robert, Kulongoski, J.T., Martin, Peter, and Sneed, Michelle, 2012, Geohydrology of Big Bear Valley, California-Phase 1-Geologic Framework, Recharge, and Preliminary Assessment of the Source and Age of Groundwater: U.S. Geological Survey Scientific Investigations Report 2012-5100, 112 p.

Flint, A.L., Flint, L.E., Hevesi, J.A., and Blainey, J.B., 2004, Fundamental concepts of recharge in the Desert Southwest: a regional modeling perspective, in Hogan, J.F., Phillips, F.M., and Scanlon, B.R., eds., Groundwater recharge in a desert environment-The Southwestern United States: Washington D.C., Water Science and Applications Series, v. 9, American Geophysical Union, p. 159-184.

Freiwald, D.A., 1984, Ground-water resources of Lanfair and Fenner Valleys and vicinity, San Bernardino County, California: U.S. Geological Survey Water-Resources Investigations Report 83-4082, 60 p.

Friedman, Irving, and O’Neil, J.R., 1977, Compilation of stable isotope fractionation factors of geochemical interest, in Fleischer, M., ed., Data of geochemistry, chap. KK: U.S. Geological Survey Professional Paper 440-KK, 12 p., and 49 fig.

Friedman, Irving, Smith, G.I., Gleason, J.D., Warden, Augusta, and Harris, J.M., 1992, Stable isotope composition of waters in southeastern California-Modern precipitation: Journal of Geophysical Research, v. 97, p. 5795-5812.

Furlong, E.T., Anderson, B.D., Werner, S.L., Soliven, P.P., Coffey, L.J., and Burkhardt, M.R., 2001, Methods of analysis by the U.S. Geological Survey National Water Quality Laboratory - determination of pesticides in water by graphitized carbon-based solid-phase extraction and high-performance liquid chromatography/mass spectrometry: U.S. Geological Survey Water-Resources Investigations Report 01-4134, 73 p.

Garbarino, J.R., 1999, Methods of analysis by the U.S. Geological Survey National Water Quality Laboratorydetermination of dissolved arsenic, boron, lithium, selenium, strontium, thallium, and vanadium using inductively coupled plasma-mass spectrometry: U.S. Geological Survey Open-File Report 99-093, 31 p.
Garbarino, J.R., Kanagy, L.K., and Cree, M.E., 2006, Determination of elements in natural-water, biota, sediment and soil samples using collision/reaction cell inductively coupled plasma-mass spectrometry: U.S. Geological Survey Techniques and Methods, book 5, chap. 1, sec. B, 88 p.

Gaudin, A.J., 1965, Larval development of the tree frogs Hyla regilla and Hyla californiae: Herpetologica, v. 21, p. $117-130$.

Getsinger, K.D., Petty, D.G., Madsen, J.D., Skogerboe, J.G., Houtman, B.A., Haller, W.T., and Fox, A.M., 2000, Aquatic dissipation of the herbicide triclopyr in Lake Minnetonka, Minnesota: Pesticide Management Science, v. 56, p. 388-400.

Gonfiantini, R., 1978, Standards for stable isotope measurements in natural compounds: Nature, v. 271, p. 534-536.

Gosner, K.L., 1960, A simplified table for staging anuran embryos and larvae with notes on identification: Herpetologica, v. 16, p. 183-190.

Greene, H.W, and Luke, C.A., 1996, Amphibian and reptile diversity in the East Mojave Desert, in Luke, C., André, J., and Herring, M., eds., Proceedings of the East Mojave Desert Symposium, November 7-8, 1992, University of California, Riverside, Technical Report, no. 10: Los Angeles, Calif., Natural History Museum of Los Angeles County, p. 53-58.

Guillette, L.J, Jr., and Edwards, T.M., 2005, Is nitrate an ecologically relevant endocrine disruptor in Vertebrates: Integrative and Comparative Biology, v. 45, no. 1, p. 19-27

Hall, W.E., and MacKevett, E.M., Jr., 1962, Geology and ore deposits of the Darwin quadrangle, Inyo County, California: U.S. Geological Survey Professional Paper 368, 87 p.

Harris, D.M., and Harris, J.M., 2009, Afoot \& afield inland empire-A comprehensive hiking guide: Berkeley, Calif., Wilderness Press, 410 p.

Hazard, L., and Rotenberry, J., 1996, Herpetofauna and vegetation survey of Cornfield Spring and Piute Spring, in Luke, C., André, J., and Herring, M., eds., Proceedings of the East Mojave Desert Symposium, November 7-8, 1992, University of California, Riverside: Natural History Museum of Los Angeles County, Technical Report no. 10, p. 69-73.

Heath, R.C., 1983, Basic ground-water hydrology: U.S. Geological Survey Water-Supply Paper 2220, 86 p.

Heaton, T.H.E., and Vogel, J.C., 1981, "Excess air" in groundwater: Journal of Hydrology, v. 50, p. 201-216. 
Hem, J.D., 1989, Study and interpretation of the chemical characteristics of natural water ( $3 d$ ed.): U.S. Geological Survey Water-Supply Paper 2254, 263 p.

Hereford, R., Webb, R.H., and Longpre, C.I., 2004, Precipitation history of the Mojave Desert Region, 1893-2001: U.S. Geological Survey Fact Sheet 117-03, 4 p.

Hoffman, E.B., Bowers, J.C., and Jensen, R.M., 1990, Water resources data California water year 1989, v. 1, southern Great Basin from Mexican border to Mono Lake Basin, and Pacific Slope Basins from Tijuana River to Santa Maria River: U.S. Geological Survey Water-Data Report 89-1, $261 \mathrm{p}$.

Intergovernmental Panel on Climate Change, 2007, Climate change 2007, The physical science basis, summary for policymakers: IPCC Secretariat, 21 p., accessed November 5, 2014, at http://www.ipcc.ch.

Izbicki, J.A., 1996, Seawater intrusion in a California coastal aquifer: U.S. Geological Survey Fact Sheet, FS-125-96, $4 \mathrm{p}$.

Johnson, P.T.J., Lunde, K.B., Ritchie, E.G., and Launer, A.E., 1999, The effect of trematode infection on amphibian limb development and survivorship: Science, v. 284, p. 802-804.

Johnson, P.T., Lunde, K.B., Ritchie, E.G., and Launer, A.E., 2004, Review of the trematode genus Ribeiroia (Psilostomidae) -Ecology, life history and pathogenesis with special emphasis on the amphibian malformation problem: Advances in Parasitology, v. 57, p. 191-253.

Jull, A.J.T., Burr, G.S., McHargue, L.R., Lange, T.E., Lifton, N.A., Beck, J.W., Donahue, D., and Lal, D., 2004, New frontiers in dating of geological, paleoclimatic and anthropological applications using accelerator mass spectrometric measurements of $14 \mathrm{C}$ and $10 \mathrm{Be}$ in diverse samples: Global and Planetary Change, v. 41, p. 309-323.

Kiesecker, J.M., Belden, L.K., Shea, K., and Rubbo, M.J., 2004, Amphibian decline and emerging disease: American Scientist, v. 92, p.138-147.

Krebs, C.J., 1989, Ecological methodology: New York, Harper and Row, 654 p.

Kunkle, G.R., 1965, Computation of ground-water discharge to streams during floods, or to individual reaches during baseflow by use of specific conductance: U.S. Geological Survey Professional Paper 525-D, p. 207-210.

Kunkle, G.R., 1968, A hydrogeologic study of the groundwater reservoirs contributing base runoff to Four Mile Creek, east-central Iowa: U.S. Geological Survey WaterSupply Paper 1839-O, p. 275-344.
Lane, J.W., Jr., 2007, Using fiber-optic distributed temperature sensors to monitor groundwater and surface-water processes and interaction [abs.], in NGWA Ground Water Summit, Albuquerque, New Mexico, April 29-May 30, 2007, Proceedings: Westerville, Ohio, National Ground Water Association.

Leonard, W.P., Brown, H.A., Jones, L.L.C., McAllister, K.R., and Storm, R.M., eds., 1993, Amphibians of Washington and Oregon: Seattle, Wash., Seattle Audubon Society, 168 p.

Lips, K.R., Mendelson, J.R., III, Mušoz, A.A., CansecoMarquez, L., and Mulcahy, D.G., 2004, Direct evidence of declines in amphibian populations in montane southern Mexico: Biological Conservation, v. 119, p. 555-564.

Longcore, J.E., Pessier, A.P., and Nichols, D.K., 1999, Batrachochytrium dendrobatidis gen. et sp. nov., a chytrid pathogenic to amphibians: Mycologia, v. 91, p. 219-227.

MacKenzie, D.I., Nichols, J.D., Lachman, G.B., Droege, S., Royle, J.A., and Langtimm, C.A., 2002, Estimating site occupancy when detection probabilities are less than one: Ecology, v. 83, p. 2,248-2,255.

Madsen, J.E., Sandstrom, M.W., and Zaugg, S.D., 2003, Methods of analysis by the U.S. Geological National Water Quality Laboratory - A method supplement for the determination of Fipronil and degradates in water by gas chromatography/ mass spectrometry: U.S. Geological Survey Open-File Report 02-462, $11 \mathrm{p}$.

Maksimowich, D.S., and Mathis, A., 2000, Parasitized salamanders are inferior competitors for territories and food resources: Ethology, v. 106, p. 319-329.

Manning, A.H., and Solomon, D.K., 2003, Using noble gases to investigate mountain-front recharge: Journal of Hydrology, v. 275, p. 194-207.

Mast, M.A., and Clow, D.W., 2008, Effects of 2003 wildfires on stream chemistry in Glacier National Park, Montana: Hydrological Processes, v. 22, p. 5013-5023.

Mazor, Emanuel, 1991, Applied chemical and isotopic groundwater hydrology: Buckingham, England, Open University Press, $274 \mathrm{p}$.

McAllister, C.T., and Trauth, S.E., 1995, New host records for Myxidium serotinum (Protozoa: Myxosporea) from North American amphibians: Journal of Parasitology, v. 81, p. 485-488.

McGurty, B.M., 1977, Reptiles and amphibians of the eastern Mojave Desert: Moreno Valley, Calif., U.S. Department of the Interior, Bureau of Land Management, $106 \mathrm{p}$. 
McLain, B.J., 1993, Methods of analysis by the U.S. Geological Survey National Water Quality Laboratory; determination of chromium in water by graphite furnace atomic absorption spectrophotometry: U.S. Geological Survey Open-File Report 93-449, 16 p.

Meteyer, C.U., 2000, Field guide to malformations of frogs and toads - with radiographic interpretations: U.S. Geological Survey Biological Science Report 2000-0005, 20 p.

Metropolitan Water District and Bureau of Land Management, 2001, Cadiz groundwater storage and dry-year supply program, San Bernardino County, California: Final Environmental Impact Report, Final Environmental Impact Statement.

Miller, A.H., and Stebbins, R.C., 1964, The lives of desert animals in Joshua Tree National Monument: Berkeley, Calif., University of California Press, $452 \mathrm{p}$.

Muths, Erin, and Corn, P.S., 2000, Boreal toad, in Reading, R.P., and Miller, B., eds., Endangered animals, a reference guide to conflicting issues: Westport, Conn., Greenwood Press, p. 60-65.

Muths, Erin, Corn, P.S., Pessier, A.P., and Green, D.E., 2003, Evidence for disease related amphibian decline in Colorado: Biological Conservation, v. 110, p. 357-365.

Muths, Erin, Gallant, A.L., Campbell Grant, E.H., Battaglin, W.A., Green, D.E., Staiger, J.S., Walls, S.C., Gunzburger, M.S., and Kearney, R.F., 2006, The amphibian research and monitoring initiative (ARMI) - 5-year report: U.S. Geological Survey Scientific Investigations Report 2006-5224, $77 \mathrm{p}$.

Nalder, I.A., and Wein, R.W., 1998, Spatial interpolation of climatic normals - test of a new method in the Canadian boreal forest: Agriculture and Forest Meteorology, v. 92, p. 211-225.

National Park Service, 1999, Natural resource challengeThe National Park Service's action plan for preserving 15 natural resources: Washington D.C., U.S. Department of the Interior, National Park Service, 20 p.

National Park Service, 2000, Mojave National Preserve general management plan: Mojave National Preserve, Calif., U.S. Department of the Interior, National Park Service, $316 \mathrm{p}$.

Ney, J.J., 1993, Practical use of biological statistics, in Kohler, C.C., and Hubert, W.A., eds., Inland fisheries management of North America: Bethesda, Md., American Fisheries Society, p. 137-158.

Nielson, J.E., Frisken, J.G., Jachens, R.C., and McDonnell, J.R., 1987, Mineral resources of the Fort Piute Wilderness study area, San Bernardino County, California: U.S. Geological Survey Bulletin 1713-C, 12 p.
Nishikawa, Tracy, Izbicki, J.A.,Hevesi, J.A., Stamos, C.L., and Martin, Peter, 2004, Evaluation of geohydrologic framework, recharge estimates, and ground-water flow of the Joshua Tree area, San Bernardino County, California: U.S. Geological Survey Scientific Investigations Report 2004-5267, 115 p.

Ostlund, H.G., and Werner, E., 1962, The electrolytic enrichment of tritium and deuterium for natural tritium measurements, in tritium in the physical and biological sciences, v. I: Vienna, International Atomic Energy Agency, p. 95-104.

Ouellet, M., 2000, Amphibian deformities - current state of knowledge, in Sparling, D.W., Linder, V., and Bishop, C.A., eds., Ecotoxicology of amphibians and reptiles: Pensacola, Fla., Society for Environmental Toxicology and Contaminants Press, p. 617-661.

Ouellet, M., Bonin, J., Rodrigue, J., DesGranges, J., and Lair, S., 1997, Hindlimb deformities (ectromelia, ectrodactyly) in free-living anurans from agricultural habitats: Journal of Wildlife Diseases, v. 33, p. 95-104.

Parkhurst, D.L., and Appelo, C.A.J., 1999, User's guide to PHREEQC (v. 2)-A computer program for speciation, batch-reaction, one-dimensional transport, and inverse geochemical calculations: U.S. Geological Survey WaterResources Investigations Report 99-4259, 310 p.

Patton, C.J., and Kryskalla, J.R., 2003, Methods of analysis by the U.S. Geological Survey National Water Quality Laboratory - evaluation of alkaline persulfate digestion as an alternative to Kjeldahl digestion for determination of total and dissolved nitrogen and phosphorus in water: U.S. Geological Survey Water-Resources Investigations Report 03-4174, $33 \mathrm{p}$.

Patton, C.J., and Truitt, E.P., 1992, Methods of analysis by the U.S. Geological Survey National Water Quality Laboratory - determination of total phosphorus by a Kjeldahl digestion method and an automated colorimetric finish that includes dialysis: U.S. Geological Survey Open-File Report 92-146, 39 p.

Patton, C.J., and Truitt, E.P., 2000, Methods of analysis by the U.S. Geological Survey National Water Quality Laboratory-Determination of ammonium plus organic nitrogen by a Kjeldahl digestion method and an automated photometric finish that includes digest cleanup by gas diffusion: U.S. Geological Survey Open-File Report 00-170, 31 p.

Perkins, P.J., Boermans, H.J, and Stephenson, G.R., 2000, Toxicity of glyphosate and triclopyr using the frog embryo teratogenesis assay-Xenopus: Environmental Toxicology and Chemistry, v. 19, p. 940-945.

Persons, T.B., and Nowak, E.M., 2006, Inventory of amphibians and reptiles at Death Valley National Park: U.S. Geological Survey Open-File Report 2006-1233, 32 p. 
Persons, T.B., and Nowak, E.M., 2007, Inventory of amphibians and reptiles at Mojave National Preserve-Final report: U.S. Geological Survey Open-File Report 2007-1109, 72 p.

Phillipsen, I.C., and Metcalf, A.E., 2009, Phylogeography of a stream-dwelling frog (Pseudacris cadaverina) in southern California: Molecular Phylogenetics and Evolution, v. 53, p. 152-170.

Piper, A.M., 1944, A graphic procedure in the geochemical interpretation of water analyses: American Geophysical Union Transactions, v. 25, p. 914-923.

Poff, N.L., Allan, J.D., Bain, M.B., Karr, J.R., Prestegaard, K.L., Richter, B.D., Sparks, R.E., and Stromberg, J.C., 1997, The natural flow regime-A paradigm for river conservation and restoration: BioScience, v. 47, p. 769-784.

Pohlmann, K.F., Campagna, D.J., Chapman, J.B., and Earman, S., 1998, Investigation of the origin of springs in the Lake Mead National Recreation Area: Desert Research Institute, Water Resources Center, 51 p., 3 appendixes.

PRISM Climate Group, 2014, PRISM climate data: PRISM Climate Group, Oregon State University, accessed September 3, 2014, at http://prism.oregonstate.edu.

Rand, G.M., Wells, P.G., and McCarty, L.S., 1995, Introduction to aquatic toxicology, in Rand, G.M., ed., Fundamentals of aquatic toxicology-Effects, environmental fate, and risk assessment ( $2 \mathrm{~d}$ ed.): Washington D.C., Taylor and Francis, p. 3-67.

Reaburn and Bowen, Consulting Engineers, 1928, Report upon the effect of additional water diversions from Darwin Wash Drainage upon existing water development, Riverside, Calif., [n.p.]

Rogers, J.J.W., 1961, Igneous and metamorphic rocks of the western portion of Joshua Tree National Monument, Riverside and San Bernardino Counties, California: California Division of Mines, Special Report 68, 26 p.

Rouse, J.D, Bishop, C.A., and Struger, John, 1999, Nitrogen pollution - an assessment of its threat to amphibian survival: Environmental Health Perspectives, v. 107, no. 10, p. 799-803.

Rutledge, A.T., 1993, Computer programs for describing the recession of ground-water discharge and for estimating mean ground-water recharge and discharge from streamflow records: U.S. Geological Survey Water-Resources Investigations Report 93-4121, 43 p.
Sandstrom, M.W., Stroppel, M.E., Foreman, W.T., and Schroeder, M.P., 2001, Methods of analysis by the U.S. Geological Survey National Water Quality Laboratory-determination of moderate-use pesticides and selected degradates in water by C-18 solid-phase extraction and gas chromatography/mass spectrometry: U.S. Geological Survey WaterResources Investigations Report 01-4098, 70 p.

Schertz, R.B., Alexander, R.B., and Ohe, D.J., 1991, The computer program EStimate TREND (ESTREND), a system for the detection of trends in water-quality data: U.S. Geological Survey Water-Resources Investigations Report 91-4040, $63 \mathrm{p}$.

Schlosser P., Stute, M., Dorr, H., Sonntag, C., and Munnich, K.O., 1988, Tritium $/{ }^{\beta} \mathrm{He}$ dating of shallow groundwater: Earth and Planetary Science Letters, v. 89, p. 353-362.

Schroeder, R.A., Orem, W.H., and Kharaka, Y.K., 2002, Chemical evolution of the Salton Sea, California - nutrient and selenium dynamics: Hydrobiologia, v. 473, p. 23-45.

Seager, R., Ting, M., Held, I., Kushnir, Y., Lu, J., Vecchi, G., Huang, H.P., Harnik, N., Leetmaa, A., Lau, N.-C., Li, C., Velz, J., and Naik, N., 2007, Model projections of imminent transition to a more arid climate in southwestern North America: Science, v. 316, p. 1181-1184.

Sessions, S.K., and Ruth, S.B., 1990, Explanations for naturally occurring supernumery limbs in amphibians: Journal of Experimental Zoology, v. 254, p. 38-47.

Sladky, K.K., Norton, T.M., and Loomis, M.R., 2000, Trombiculid mites (Hannemania sp.) in canyon tree frogs (Hyla arenicolor): Journal of Zoo and Wildlife Medicine, v.13, p. $570-575$.

Smith, G.I., Friedman, Irving, Gleason, J.D., and Warden, Augusta, 1992, Stable isotope composition of waters in southeastern California - Groundwaters and their relation to modern precipitation: Journal of Geophysical Research, v. 97 . p. 5813-5823.

Spencer, C.N., Gabel, K.O., and Hauer, F.R., 2003, Wildfire effects on stream food webs and nutrient dynamics in Glacier National Park, USA: Forest Ecology and Management, v. 178, p. 141-153.

Stamos, C.L., Glockhoff, C.S., McPherson, K.R., and Julich, R.J., 2009, Water-level and land-subsidence studies in the Mojave River and Morongo groundwater basins: U.S. Geological Survey Scientific Investigations Report 2007-5097, [n.p.] 
Stebbins, R.C., 1951, Amphibians of western North America: Berkeley, Calif., University of California Press, 539 p.

Stebbins, R.C., 2003, A field guide to western reptiles and amphibians ( $3 \mathrm{~d}$ ed.): Boston, Mass., Houghton Mifflin Co., $533 \mathrm{p}$.

Stebbins, R.C., and Cohen, N.W., 1995, A natural history of amphibians: Princeton, N.J., Princeton University Press, $316 \mathrm{p}$.

Stoffer, Phillip, 2004, Desert landforms and surface processes in the Mojave National Preserve and vicinity: U.S. Geological Survey Open-File Report 2004-1007, accessed November 5, 2014, at http://pubs.usgs.gov/of/2004/1007/.

Stone, P., Dunne, G.C., Stevens, C.H., Gulliver, R.M., 1998, Geologic map of paleozoic and mesozoic rocks in parts of the Darwin and adjacent quadrangles, Inyo County, California: U.S. Geological Survey Miscellaneous Investigations Series Map I-1932.

Storer, T.I., 1925, A synopsis of the amphibia of California: Berkeley, Calif., University of California Publications in Zoology, no. 27, 342 p.

Struzeski, T.M., DeGiacomo, W.J., and Zayhowski, E.J., 1996, Methods of analysis by the U.S. Geological Survey National Water Quality Laboratory-determination of dissolved aluminum and boron in water by inductively coupled plasma-atomic emission spectrometry: U.S. Geological Survey Open-File Report 96-149, 17 p.

Sullivan, B.K., and Fernandez, P.J., 1999, Breeding activity, estimated age-structure, and growth in Sonoran Desert anurans: Herpetologica, v. 55, p. 334-343.

Tevis, Loyd, Jr., 1966, Unsuccessful breeding by desert toads (Bufo punctatus) at the limit of their ecological tolerance: Ecology, v. 47, p. 766-775.

Thatcher, L.L., Janzer, V.J., and Edwards, K.W., 1977, Methods for the determination of radioactive substances in water: U.S. Geological Survey Techniques of Water-Resources Investigations, book 5, chap. A5, 95 p.

Thomas, K.A., Franklin, J., Keeler-Wolf, T., and Stine, P., 2005, Mojave Desert ecosystem program - Central Mojave vegetation database: U.S. Geological Survey Fact Sheet 2005-3098, 3 p.

Timme, P.J., 1995, National Water Quality Laboratory 1995 services catalog: U.S. Geological Survey Open-File Report 95-352, $120 \mathrm{p}$.

Trent, D.D., 1984, Geology of the Joshua Tree National Monument, Riverside and San Bernardino Counties: California Geology, p. 75-86.
Turekian, K.K., and Wedepohl, K.H., 1961, Distribution of the elements in some major units of the Earth's crust: Geological Society of America Bulletin, v. 72, p. 175-182.

Turner, F.B., and Wauer, R.H., 1963, A survey of the herpetofuana of the Death Valley area: Great Basin Naturalist, v. 23, p. 119-128.

Turnipseed, D.P., and Sauer, V.B., 2010, Discharge measurements at gaging stations: U.S. Geological Survey Techniques and Methods, book 3, chap. A8, 87 p., [Also available at http://pubs.usgs.gov/tm/tm3-a8/.]

Tyler, M.J., 1998, Frogs as environmental monitoring organisms, ${ }^{\text {in }}$ Tyler, M.J., ed., Australian frogs-A natural history: Ithaca, N.Y., Cornell University Press, p. 141-160.

U.S. Environmental Protection Agency, 2010, List of contaminants and their MCLs: U.S. Environmental Protection Agency, accessed May 19, 2010, at http:/www.epa.gov/ safewater/mcl.html\#sec.

U.S. Geological Survey, 1989, Federal Glossary of selected terms - Subsurface-water and solute transport: U.S. Geological Survey, Office of Water Data Coordination, Ground Water Subcommittee of the Federal Interagency Advisory Committee on Water Data, 38 p.

U.S. Geological Survey, 2006a, National field manual for the collection of water-quality data: U.S. Geological Survey Techniques of Water-Resources Investigations, book 9, chaps. A1-A9, accessed July 7, 2006, at http://pubs.water. usgs.gov/twri9A.

U.S. Geological Survey, 2006b, USGS aquatic species and habitat assessment protocol for southcoast ecoregion rivers, streams, and creeks: San Diego, Calif., U.S. Geological Survey protocol, $48 \mathrm{p}$.

U.S. Geological Survey, 2006c, USGS vertebrate sampling protocols for basic procedures and equipment use: San Diego, Calif., U.S. Geological Survey protocol, 30 p.

Weir, J.E., and Bader, J.S., 1963, Ground water and related geology of Joshua Tree National Monument, California: U.S. Geological Survey Open-File Report 63-137, 122 p.

Weiss, R.F., 1968, Piggyback sampler for dissolved gas studies on sealed water samples: Deep Sea Research, v. 15. p. 721-735.

Welbourn, W.C., Jr., and Loomis, R. B., 1975, Hannemania (Acarina: Trombiculidae) and their anuran hosts at Fortynine Palms Oasis, Joshua Tree National Monument: Bulletin of the Southern California Academy of Sciences, v. 74, p. 15-19.

Wright, A.H., and Wright, A.A., 1949, Handbook of frogs and toads of the United States and Canada (3d ed.): Ithaca, N.Y., Comstock Publishing Associates, 640 p. 


\section{Appendixes}


This page intentionally left blank. 
Appendix 1. Background Information on Classes, or Types, of Water-Quality Constituents Analyzed for the Springs Study in the Mojave Network Parks, 2005-06

By Roy A. Schroeder 


\section{Field Data}

The $\mathrm{pH}$ of many natural waters is slightly alkaline $(\mathrm{pH}$ greater than or equal to 7) as a result of buffering by the carbonate-bicarbonate $\left(\mathrm{CO}_{3}-\mathrm{HCO}_{3}\right)$ dissolution/precipitation process (Hem, 1989). Buffering capacity is measured by titration with sulfuric acid $\left(\mathrm{H}_{2} \mathrm{SO}_{4}\right)$ to $\mathrm{pH}=4.5$ (fixed end point) and reported as alkalinity in milligrams per liter $(\mathrm{mg} / \mathrm{L})$ as calcium carbonate $\left(\mathrm{CaCO}_{3}\right)$, or by incremental (Gran) titration, and reported as bicarbonate and carbonate concentration. Many dissolved calcium $(\mathrm{Ca})$ concentrations are restricted by the $\mathrm{pH}$ and alkalinity because the water is saturated with respect to $\mathrm{CaCO}_{3}$

Electrical conductance is caused by ions dissolved in the water, so specific conductance (EC) at 25 degrees Celsius $\left({ }^{\circ} \mathrm{C}\right)$ serves as a proxy for the following similar properties: residue on evaporation at $180^{\circ} \mathrm{C}(\mathrm{ROE})$, dissolved-solids concentration (DSC), and salinity (Hem, 1989). The ratio of $\mathrm{ROE}$ in $\mathrm{mg} / \mathrm{L}$ to $\mathrm{EC}$ in microsiemens per centimeter $(\mu \mathrm{S} / \mathrm{cm})$ generally falls between about 0.55 and 0.75 depending on relative contribution of the major ions (Hem, 1989). These are general indicators for water quality that reflect length of time and ease of dissolution of the minerals with which the groundwater has been in contact.

Dissolved oxygen (DO) and dissolved hydrogen sulfide $\left(\mathrm{H}_{2} \mathrm{~S}\right)$ provide an indication of the oxidation-reduction (redox) state of the water (Hem, 1989). Oxygen (O) from the atmosphere contained in the water at the time of recharge is consumed by biological (respiration and microbial) activity; and reduced inorganic minerals, such as pyrite $\left(\mathrm{FeS}_{2}\right)$ and siderite $\left(\mathrm{FeCO}_{3}\right)$ in the subsurface (Hem, 1989), result in a DO concentration in groundwater (and water as it issues from the spring) that is undersaturated with respect to equilibrium with the atmosphere. With time, the oxidizable material in the aquifer will be removed or altered for long distances from the point of recharge (Hem, 1989). The chemical compound, $\mathrm{H}_{2} \mathrm{~S}$, results from microbial sulfate $\left(\mathrm{SO}_{4}\right)$ reduction after all available $\mathrm{O}$ has been consumed (Hem, 1989).

\section{Major-Ion Composition}

The major-ion composition of spring water is controlled by the natural chemistry of the recharge water and geochemical reactions, primarily dissolution and precipitation of minerals, in the subsurface (Hem, 1989). Reactions that affect major-ion concentrations include aluminosilicate dissolution, calcite dissolution and precipitation, cation exchange on clays, and microbial $\mathrm{SO}_{4}$ reduction. The aqueous concentration of major ions is controlled by kinetics (rate of dissolution of minerals) and equilibrium (saturation with respect to minerals). A computerized geochemical model (PHREEQC; Parkhurst and Apello, 1999) can be used to ascertain whether or not water of a given composition is in thermodynamic equilibrium (saturated) with respect to selected minerals; this study was concerned primarily with calcite and silica. The model uses thermodynamic data to calculate a saturation index (SI) defined as the logarithm (base 10) of the ion activity product (from measured concentration) divided by the solubility product. Negative values indicate under-saturation, so equilibrium favors dissolution of the mineral, and positive values indicate over-saturation, so precipitation of the mineral from solution should occur.

Trilinear Piper diagrams (Piper, 1944) can be used to display the relative contribution of major cations and anions, on a charge-equivalent basis, to the total ionic content of the water. Piper diagram percentage scales show cation concentrations on a left triangle and anion concentrations on a right triangle, and a central diamond integrates the data. Piper diagrams provide a useful visual depiction for comparing or contrasting differences in major-ion composition at multiple locations, and can be related to causal geochemical reactions and to mixing of groundwater from multiple sources where sufficient data exist.

\section{Chloride-to-Bromide Ratios}

Chloride $(\mathrm{Cl})$ and bromide $(\mathrm{Br})$ are similar to one another in that both are chemically and biologically unreactive anions (they are conservative constituents; Hem, 1989). Salt injected into the atmosphere during evaporation from the ocean surface is the source of both in precipitation (Davis and others, 1998). The $\mathrm{Cl} / \mathrm{Br}$ mass ratio in seawater is about 285 , so most natural waters have a ratio that is close to this value (Davis and others, 1998). The $\mathrm{Cl}$ concentration in atmospheric precipitation ranges from about 0.1 to almost $200 \mathrm{mg} / \mathrm{L}$; concentrations decrease rapidly with increasing distance inland from the ocean (Davis and others, 1998). $\mathrm{The} \mathrm{Cl} / \mathrm{Br}$ ratio exhibits considerable scatter, but the trend also indicates a decrease with increasing distance from the coast from slightly less than the ratio of 285 in seawater to about 100-200 in precipitation farther inland where $\mathrm{Cl}$ concentration has declined to less than a few milligrams per liter (Davis and others, 1998). The slight enrichment in $\mathrm{Br}$ relative to $\mathrm{Cl}$ in precipitation destined for mountain-front recharge and nearby groundwater from coastal areas of southern California that is low in DSC results in a $\mathrm{Cl} / \mathrm{Br}$ ratio of about 200 (Schroeder and others, 1997; Land and others, 2004). Although both anions are highly soluble, $\mathrm{Br}$ is more soluble than $\mathrm{Cl}$, and because of this the insoluble residue (evaporite salt) that remains behind as water is evaporated and enriched in $\mathrm{Cl}$, so the residual solution becomes enriched in $\mathrm{Br}$. The net result is that the $\mathrm{Cl} / \mathrm{Br}$ ratio in groundwater from an arid environment can be much higher than the ratio in local precipitation because halite in bedded salt deposits, surface salt efflorescences, or salt widely disseminated in the soil has been redissolved. For example, by the time Colorado River water reaches southern California the $\mathrm{Cl} / \mathrm{Br}$ ratio is about four times higher than the ratio in seawater (Schroeder and others, 2002). 


\section{Nutrients}

Nitrogen $(\mathrm{N})$ and phosphorus $(\mathrm{P})$ concentrations are expected to be low at the springs because the water is far from areas affected by humans. Background $\mathrm{N}$ concentrations in the Mojave Desert have been reported to be about $2 \mathrm{mg} / \mathrm{L}$ (Nishikawa and others, 2003), and that would be the expected $\mathrm{N}$ concentration at the sampled springs. All the $\mathrm{N}$ at the spring's source would be in the form of nitrate $\left(\mathrm{NO}_{3}\right)$ if $\mathrm{DO}$ is present (Hem, 1989). Where $\mathrm{O}$ is absent and $\mathrm{H}_{2} \mathrm{~S}$ is present, microbial denitrification will have converted the $\mathrm{NO}_{3}$ to nitrogen gas $\left(\mathrm{N}_{2}\right)$, and only very low amounts of ammonia $\left(\mathrm{NH}_{4}\right)$ are likely to be present (Freeze and Cherry, 1979). Plants (algae) in streams or pools that receive water from springs or seeps will quickly take up any inorganic $\mathrm{N}\left(\mathrm{NO}_{3}\right.$ or $\left.\mathrm{NH}_{4}\right)$ that is available and convert it to organic N. Concentrations of $\mathrm{P}$ likely are very low because there is no significant source, and also because soils are effective at adsorbing soluble phosphate (Hem, 1989).

\section{Trace Elements}

Several trace elements are of interest because of their toxicity potential at high concentrations. Concentrations of most trace elements are expected to be low because the springs are in remote areas that are largely free of polluting activities with the possible exception of historic mining. However, a few trace elements are naturally abundant in some minerals, and where deposits containing those minerals are present and the element is sufficiently soluble, aqueous concentrations could potentially become high enough to pose a biological risk.

\section{Noble Gases}

Noble gas concentrations analyzed for this study are reported in cubic centimeters at standard temperature and pressure of $25^{\circ} \mathrm{C}$ and 1 cubic centimeter per gram of water at standard temperature and pressure $\left(\mathrm{cm}^{3} \mathrm{STP} / \mathrm{g} \mathrm{H}_{2} \mathrm{O}\right)$; and include helium (He), neon (Ne), argon (Ar), krypton (Kr), and xenon $(\mathrm{Xe})$ in order from lowest to highest molecular weight. These gases do not react chemically in the environment, so their aqueous concentrations are controlled by partitioning between gas concentrations in the shallow soil zone and the infiltrating water in contact with the soil (Mazor, 1991). Solubility of noble gases at the water table can be estimated using Henry's Law, which states that for an ideal gas there is a linear relation between the activity of a volatile species in the liquid phase and its activity in the gas phase (Stumm and Morgan, 1996). Gas solubility is dependent on temperature, pressure, and salinity with the temperature dependence likely to exert the greatest effect in the spring's environment followed by partial pressure (altitude). Solubility of all noble gases increases with decreasing temperature and, therefore, measured concentrations can be used to calculate the temperature at which the infiltrating water was last in equilibrium with the atmosphere (shallow soil gas); that is, the temperature at which recharge took place (Stute and Schlosser, 2000). The heavier (higher molecular weight) gases are more useful for this calculation than the lighter ones because of their greater sensitivity to temperature change (Mazor, 1991). For example, the solubility of $\mathrm{Ne}$ increases by only about 3 percent, whereas the solubility of Ar increases about 7 percent for each decrease in ${ }^{\circ} \mathrm{C}$ (values are only approximate because the temperature dependence is nonlinear). Partial pressure increases solubility about 1.5 percent for each 100-meter (m) decrease in altitude between 3 kilometer $(\mathrm{km})$ and sea level (Mazor, 1991).

In addition to gas solubility changing with temperature, noble gas concentrations also can be affected by "excess" air (Stute and Schlosser, 2000). Excess air enters the groundwater as infiltrating water traps bubbles of air that subsequently dissolve at higher pressures as groundwater moves to greater depth beneath the water table. Although this likely occurs to some extent in this study, it is not believed to compromise integrity of the noble-gas data. Reequilibration of noble gas concentrations in the groundwater with the atmosphere as groundwater nears the land surface, or even at the time of sampling itself, probably is much more likely to compromise integrity of the noble-gas data. More detailed discussions on the use of noble gases to determine recharge temperature can be located in Heaton and Vogel (1981), Aeschbach-Hertig and others (1999), Aeschbach-Hertig and others (2000), Stute and Schlosser (2000), and Manning and Solomon (2003).

In situ (on site) production from the decay of radioactive elements, and fluxes from the Earth's mantle, also affect $\mathrm{He}$ concentration in groundwater. In this study, He concentrations and helium-3 $\left({ }^{3} \mathrm{He}\right) /$ helium-4 $\left({ }^{4} \mathrm{He}\right)$ ratios are used to constrain estimates of water age, which is described below in the "Radioactive Isotopes" section, rather than to calculate recharge temperature.

\section{Common Atmospheric Gases}

Dissolved concentrations, reported in $\mathrm{mg} / \mathrm{L}$ of water, of several gases present in the atmosphere (other than the noble gases) also were measured. These gases included oxygen gas $\left(\mathrm{O}_{2}\right), \mathrm{N}_{2}$, carbon dioxide $\left(\mathrm{CO}_{2}\right)$, methane $\left(\mathrm{CH}_{4}\right)$, and $\mathrm{Ar}$; and they were measured in the Reston Chlorofluorocarbon (CLC) Laboratory. (Note this analysis represents a second method for the field measurement of $\mathrm{O}_{2}$ and to the Lawrence Livermore National Laboratory [LLNL] measurement of Ar.) The gases Ar and $\mathrm{N}_{2}$ can be used to calculate recharge temperature in a manner analogous to that described above for noble gases; however, there is the added complication that $\mathrm{N}_{2}$ can be produced by microbial denitrification of $\mathrm{NO}_{3}$ in the subsurface, and if present, must be corrected (Heaten and Vogel, 1981). Concentrations of $\mathrm{O}_{2}, \mathrm{CO}_{2}$, and $\mathrm{CH}_{4}$ also can be altered by microbial processes in the subsurface, or potentially even in the sealed collection bottle itself during transport and storage in the lab. 
Recharge temperature can be calculated using the dependence between $\mathrm{Ar}$ and $\mathrm{N}_{2}$ solubility, and water temperature and partial pressure as described by Heaten and Vogel (1981). The altitude of recharge can be calculated from isotopic data as described in the following section.

\section{Stable Isotopes}

Elements exist as multiple isotopes (same number of protons but differing numbers of neutrons), and many elements have more than one stable (nonradioactive) isotope. Stableisotope ratios were determined in this study for hydrogen $(\mathrm{H})$, $\mathrm{O}$, carbon $(\mathrm{C})$, and strontium $(\mathrm{Sr})$. The isotopic composition for $\mathrm{H}, \mathrm{O}$, and $\mathrm{C}$ are expressed in the standard delta $(\delta)$ notation (Gonfiantini, 1978), in units of per mil (parts per thousand), as differences relative to a standard, by:

$$
(\delta E)=\left[\left(R_{\text {sample }}-R_{\text {standard }}\right) / R_{\text {standard }}\right] \times 10^{3}
$$

where

$R \quad$ is the ratio of the heavier to the lighter isotope for a given element $(E)$.

Carbon-13 $\left({ }^{13} \mathrm{C}\right)$ and carbon-12 $\left({ }^{12} \mathrm{C}\right)$ are naturally occurring stable isotopes of C. Deuterium $\left(\mathrm{D}\right.$ or $\left.{ }^{2} \mathrm{H}\right)$ and protium $\left({ }^{1} \mathrm{H}\right)$ are naturally occurring stable isotopes of $\mathrm{H}$ and oxygen-18 $\left({ }^{18} \mathrm{O}\right)$ and oxygen-16 $\left({ }^{16} \mathrm{O}\right)$ are naturally occurring stable isotopes of $\mathrm{O}$. The standards for these isotopes $\left({ }^{2} \mathrm{H} /{ }^{1} \mathrm{H}\right.$ and ${ }^{18} \mathrm{O} /{ }^{16} \mathrm{O}$ ) are Vienna Standard Mean Ocean Water (VSMOW) and Standard Light Antarctic Precipitation (SLAP); by convention, the VSMOW value for $\delta$ is 0 per mil for both elements (Craig, 1961b), and the SLAP value is -428 per mil for deuterium ratios $(\delta \mathrm{D})$. Analytical precision is plus or minus ( \pm ) 1.5 per mil for $\delta \mathrm{D}$, and about \pm 0.5 per mil for ${ }^{18} \mathrm{O} /{ }^{16} \mathrm{O}$ ratios $\left(\delta^{18} \mathrm{O}\right)$ (Coplen, 1994; Izbicki, 1996).

The $\delta \mathrm{D}$ and $\delta^{18} \mathrm{O}$ composition of a spring sample can provide a record of the source water and its evaporative history. The isotopic composition of coastal precipitation throughout the world is correlated linearly and plots along a line known as the global meteoric water line (MWL; Craig, 1961a). Differences in the isotopic composition of precipitation occur along this line in response to trends dictated by latitude, altitude, and the temperature of condensation (Dansgaard, 1964). More negative values (depletion in the heavier relative to the lighter isotope) result when condensation takes place at colder temperatures and higher altitudes. The temperature effect, based on measurements in North America and Europe, is -0.7 per mil/ ${ }^{\circ} \mathrm{C}$ for $\delta^{18} \mathrm{O}$, which is equivalent to -5.6 per mil $/{ }^{\circ} \mathrm{C}$ for $\delta \mathrm{D}$ (Dansgaard, 1964). The altitude effect, based on measurements made on the western flank of the Sierra Nevada Mountain Range, is -2.3 per mil/ $\mathrm{km}$ for $\delta^{18} \mathrm{O}$ (Ingraham and Taylor, 1991; Rose and others, 1996). This is equivalent to -18.4 per $\mathrm{mil} / \mathrm{km}$ for $\delta \mathrm{D}$ if isotope data fall on the global MWL or on a local line that is parallel to the MWL.
Water that has been partly evaporated is enriched in heavier isotopes relative to its original composition (Mazor, 1991); these values plot to the right of the MWL (for $\delta \mathrm{D}$ as the vertical and $\delta^{18} \mathrm{O}$ as the horizontal axis). Isotopic data for groundwater commonly plots to the right of the MWL because the water has undergone some evaporation at land surface before recharge. A similar result is commonly exhibited in precipitation from areas that are so arid that some evaporation takes place following condensation in the low-humidity atmosphere before the precipitation falls to the ground (Mazor, 1991). This effect is evident for isotopic data from a 32-station precipitation network operated between about 32.5 and $36.5^{\circ} \mathrm{NE}$ of the Sierra Nevada in central California and the Coastal Range in southern California (Freidman and others, 1992; Smith and others, 1992; Gleason and others, 1994), and is especially evident during the summer season and at the low-altitude stations on the desert floor (Friedman and others, 1992, figs. 8 and 9).

Isotopic data from the aforementioned network, which collected 6-month composites during the winter and summer seasons between 1982 and 1989, can be used to examine whether the altitude relation derived from data on the western flank of the Sierra Nevada is nearly the same at the three areas of this study, and to calculate the average altitude of recharge to each spring. Extreme variability in isotopic precipitation from the network reflects the complex interplay of precipitation source, seasonality, and topography, so data from paired stations most similar to each study area (generally the closest ones) were selected for examination. Altitude and annual precipitation-weighted mean $\delta \mathrm{D}$ for each of the precipitation stations is given in parentheses. The paired stations are at Darwin $(1,435 \mathrm{~m}, \delta \mathrm{D}$ is -87 per mil) and Trona $(525 \mathrm{~m}, \delta \mathrm{D}$ is -69 per mil) for Darwin Falls, Mitchell Caverns $(1,315 \mathrm{~m}$, $\delta \mathrm{D}$ is -74 per mil) and Needles $(295 \mathrm{~m}, \delta \mathrm{D}$ is -57 per mil) for Piute Spring, and Joshua Tree $(1,280 \mathrm{~m}, \delta \mathrm{D}$ is -75 per mil) and Twentynine Palms (570 m, $\delta \mathrm{D}$ is -64 per mil) for Fortynine Palms Oasis. The difference in altitude equates to a difference in $\delta \mathrm{D}$ calculated using the reported altitude effect in the western Sierra Nevada of 16.7 per mil, 18.8 per mil, and 13.1 per mil, which compares favorably with the measured difference in volume-weighted averages of 18 per mil, 17 per mil, and 11 per mil, respectively (Friedman and others, 1992, table 5), for each of these three paired stations. Hence, $\delta \mathrm{D}$ data from springs at each of the three study areas can then be used, in conjunction with average values in precipitation, by extrapolating from the higher of each paired station, and the relation between isotope ratio and altitude for each spring $\left(Z_{S P}\right)$ to estimate the average altitude of recharge to the spring. The method has been used by Martin (2011) for thermal springs near Palm Springs, California.

The average altitude of recharge to the spring $\left(\mathrm{alt}_{R S P}\right)$ calculation can be expressed as a two-step process. The first step is calculation of the relation $\left(Z_{S P}\right)$ between isotope ratio and altitude for each spring by substituting the isotope $(\delta)$ and 
altitude (alt) information from its nearby paired precipitation monitoring stations (P2 and P1) as follows:

$$
Z_{S P}=\left(\delta_{P 2}-\delta_{P 1}\right) /\left(\text { alt }_{P 2}-\text { alt }_{P 1}\right)
$$

where

$Z_{S P} \quad$ is the relation between isotope ratio and altitude for a particular spring (SP),

$\delta_{P 1} \quad$ is the isotopic ratio measured at monitoring station P1,

$\delta_{P 2} \quad$ is the isotopic ratio measured a monitoring station P2,

alt $_{P 1} \quad$ is the altitude of monitoring station P1, and

alt $_{P 2} \quad$ is the altitude of monitoring station P2.

These calculated "local" values of $Z_{S P}$ are instructive for comparison between the different springs and to published values from other areas. The final step substitutes the value of $Z_{S P}$ and isotope data from each spring $\left(\delta_{S P}\right)$ to calculate the average altitude of recharge to the spring $\left(\right.$ alt $\left._{R S P}\right)$ as follows:

$$
\operatorname{alt}_{R S P}=\operatorname{alt}_{P 2}+\left[\left(\delta_{S P}-\delta_{P 2}\right) / Z_{S P}\right]
$$

where

$$
\begin{aligned}
& \text { alt }_{\text {RSP }} \quad \text { is the average altitude of recharge to spring } \\
& \text { SP and the other symbols are as defined in } \\
& \text { equation } 2 .
\end{aligned}
$$

Note that substituting data from the precipitation station P1 in equation 2 will yield an identical result. The $a_{t} t_{R S P}$ values presented in this report were calculated using the altitude relation derived from data on the western flank of the Sierra Nevada (Ingraham and Taylor, 1991; Rose and others, 1996) instead of the local $Z_{S P}$ as it is considered more robust because more than two precipitation stations were used to develop that relation, and all values are about the same. For example, the alt $_{R S P}$ for the Darwin Spring was calculated to be 2,348 m by substituting the following values into equation 2 :

- alt $_{P_{2}}$ is $1,435 \mathrm{~m}$, which is the altitude of the Darwin station (Freidman and others, 1992).

- $\delta_{S P}$ is -103.8 per mil, which is the mean $\delta \mathrm{D}$ of samples collected from Darwin Spring (table 6).

- $\delta_{P 2}$ is -87 per mil, which is the $\delta \mathrm{D}$ of the Darwin station (Freidman and others, 1992).

- $Z_{S P}$ is $-0.0184 \mathrm{per} \mathrm{mil} / \mathrm{m}$, which is the relation between isotope ratio and altitude (Ingraham and Taylor, 1991; Rose and others, 1996).
Carbon-13 $\left({ }^{13} \mathrm{C}\right)$ and carbon- $12\left({ }^{12} \mathrm{C}\right)$ are naturally occurring stable isotopes of $\mathrm{C}$. The ratio of these isotopes is expressed as differences relative to the standard Vienna Pee Dee Belemnite (VPDB; Friedman and O’Neil, 1977; Coplen, 1994). Analytical precision is about \pm 0.5 per mil for the carbon-13/carbon-12 ratio $\left(\delta^{13} \mathrm{C}\right)$. Some representative $\delta^{13} \mathrm{C}$ values are about 0 per mil in carbonates, about -8 per mil in atmospheric $\mathrm{CO}_{2}$ at present (2014), and about -25 per mil for organic carbon in freshwater sediments (Degens, 1969) and aquifer materials (Clark and Fritz, 1999) for which the range is about $\pm 2-3$ per mil. The isotopic composition of dissolved inorganic carbon (DIC), carbonate, and bicarbonate in groundwater is usually derived from a mixture of atmospheric $\mathrm{CO}_{2}$, oxidation (degradation or mineralization) of organic carbon, and dissolution of minerals. Because an exchange of $\mathrm{C}$ isotopes (equilibration) between carbonate minerals and DIC occurs, albeit slowly, groundwater could acquire less negative $\delta^{13} \mathrm{C}$ values as it moves along a flow path from infiltration to exit at the spring. Stable carbon isotopes are used in this study, in conjunction with radiogenic carbon-14 $\left({ }^{14} \mathrm{C}\right)$, in a simple two-member mixing model (Mazor, 1991) to make inferences about the extent to which this exchange has caused the calculated ${ }^{14} \mathrm{C}$ age to overestimate the actual time elapsed since recharge as described in the next section.

Strontium ( $\mathrm{Sr}$ ) has two stable isotopes (strontium-87 $\left[{ }^{87} \mathrm{Sr}\right]$ and strontium- $\left.88\left[{ }^{88} \mathrm{Sr}\right]\right)$ that are measured and reported directly as atom ratios $\left({ }^{87} \mathrm{Sr} /{ }^{86} \mathrm{Sr}\right)$ to 4 or 5 significant digits. Strontium- $87\left({ }^{87} \mathrm{Sr}\right)$ in rocks and minerals is produced by decay of the radioactive isotope of rubidium (rubidium- 87 ; ${ }^{87} \mathrm{Rb}$ ), which has a half-life of $5 \times 10^{10}$ years (Aldrich and others, 1956). Ratios of $\mathrm{Sr}$ depend on both age and ${ }^{87} \mathrm{Rb}$ content of rocks and minerals; therefore, there can be large differences related to composition and age (Turekian and Wedepohl, 1961). The dissolution and exchange of strontium between solid and aqueous phases is fairly rapid, so groundwater commonly acquires a $\mathrm{Sr}$ isotopic signature that matches the geologic unit with which it was most recently in contact (Turekian and Wedepohl, 1961). Variations in Sr isotopes because of differences in time of sample collection are used in this study to assess whether the spring discharge flowed through the same geologic units at all times, or whether the relative contribution from different geologic units changes seasonally and annually in response to changes in rainfall amount. Strontium isotopes provide an independent method of assessment that can corroborate conclusions inferred from major-ion composition because each is affected by differing underlying geochemical factors. 


\section{Radioactive Isotopes}

Tritium $\left({ }^{3} \mathrm{H}\right)$ and ${ }^{14} \mathrm{C}$ were the two radioactive isotopes used in this study to determine water age; that is, the time it takes for recharging (infiltrating) water to move through the subsurface until it exits at the spring. For the simplest case (plug flow and no mixing), water age can be calculated from the radioactive decay equation:

$$
\begin{aligned}
& A=A_{0}^{-\lambda t}, \text { or its equivalent } \\
& 2.303\left(\log [A]-\log \left[A_{0}\right]\right)=-\lambda t
\end{aligned}
$$

where

$$
\begin{aligned}
& A \text { is the current activity, } \\
& A_{0} \text { is the activity in the water at its time of } \\
& \text { recharge, } \\
& t \quad \text { is the decay constant, } \\
& \text { is time. }
\end{aligned}
$$

The half-life (time for activity of the nuclide to decay by half) is given by $t_{1 / 2}=0.693 / \lambda$. The half-life is 12.32 years for ${ }^{3} \mathrm{H}$ (Lucas and Unterweger, 2000) and 5,730 years for ${ }^{14} \mathrm{C}$ (Godwin, 1956).

Tritium is a naturally occurring radioactive isotope produced by the interaction of high-energy cosmic rays with the upper atmosphere (Mazor, 1991). For this study, its activity in samples was measured and reported in tritium units (TUs). In $10^{18}$ hydrogen atoms, $1 \mathrm{TU}$ is equivalent to $1{ }^{3} \mathrm{H}$ atom (Taylor and Roether, 1982). Activity also is commonly reported in units of picocuries per liter $(\mathrm{pCi} / \mathrm{L} ; 3.19 \mathrm{pCi} / \mathrm{L}$ is approximately $1 \mathrm{TU})$. High amounts of ${ }^{3} \mathrm{H}$ were introduced into the environment during the atmospheric detonation of thermonuclear bombs beginning in the early 1950s. This raised the ${ }^{3} \mathrm{H}$ concentration in precipitation several-hundred fold by the time testing was halted in 1963; however, ${ }^{3} \mathrm{H}$ concentrations in precipitation subsequently declined and are currently (2006) near natural background levels in many locations. Activities ranging from 1.3 to 2.6 TU were measured in 7 of 8 rainfall samples collected during 2006 at R.A. Schroeder's residence on the coast in San Diego County. Activities in the Sierra Nevada snow pack were 3-4 TU during the winter of 2006-07 (R.L. Michel, written commun., 2007).

Absence of ${ }^{3} \mathrm{H}$ indicates water that recharged the aquifer earlier than about 1950; very high activity indicates water that infiltrated near the time of the "bomb peak" in the early 1960s; and low activity indicates either very recent recharge or a mixture of water with different ages if the simplifying assumptions are not valid (Mazor, 1991). The decay equation above (equation 4) can be used to calculate water age if ${ }^{3} \mathrm{H}$ activity at the time of infiltration is known. Tritium decays to the stable isotope of $\mathrm{He},{ }^{3} \mathrm{He}$, so the initial activity of ${ }^{3} \mathrm{H}$ equals the sum of present-day (2006) ${ }^{3} \mathrm{H}$ plus any ${ }^{3} \mathrm{He}$ (tritogenic helium). However, the direct application of this is complicated because ${ }^{3} \mathrm{H}$ decay is not the only possible source for ${ }^{3} \mathrm{He}$. Additional details on the calculation of ${ }^{3} \mathrm{H}-{ }^{3} \mathrm{He}$ water ages can be located in Izbicki and others (2003).
A naturally occurring radioactive isotope of carbon, ${ }^{14} \mathrm{C}$, is produced by cosmic-ray spallation from nitrogen in the atmosphere (Mazor, 1991). Because of its long half-life, it can be used to date water that is much older than is possible with ${ }^{3} \mathrm{H}$. Carbon-14 is measured on the DIC in water and reported as percent modern carbon (pmc) by comparing ${ }^{14} \mathrm{C}$ activities to the specific activity of National Bureau of Standards oxalic acid; 12.88 disintegrations per minute per gram $(\mathrm{g})$ of $\mathrm{C}$ in the year 1950 equals 100 pmc (Mazor, 1991). Activity of ${ }^{14} \mathrm{C}$ has varied in the past in response to fluctuations in its natural production rate; activity has been decreased by injection of $\mathrm{CO}_{2}$ containing no ${ }^{14} \mathrm{C}$ into the atmosphere from burning of fossil fuel since the beginning of the Industrial Age 200 years ago, and activity recently has increased with the nuclear era (Mazor, 1991). These factors are not important in the calculation of ${ }^{14} \mathrm{C}$ water ages for old water in this study as any effect is much less significant than is the exchange of aqueous DIC with carbonate minerals. The carbonate minerals have little or no ${ }^{14} \mathrm{C}$ resulting in a decrease in activity and corresponding increase in calculated "apparent" age of the DIC.

A simple two-member mixing model (Mazor, 1991) is used in this study to correct calculated ${ }^{14} \mathrm{C}$ ages for exchange with radiocarbon-dead carbonate in the soil. One end member is soil carbonate assumed to have a $\delta^{13} \mathrm{C}$ value of 0 per mil and no ${ }^{14} \mathrm{C}$. The other end member must then correspond to the $\delta^{13} \mathrm{C}$ soon after water has reached the water table, but after it has undergone the rapid initial phases of biological and chemical mineralization and exchange that are characteristic of recharge. A mean value of -14.56 per mil for three samples from Fortynine Palms Oasis was chosen because this water was determined using ${ }^{3} \mathrm{H}-{ }^{3} \mathrm{He}$ dating to be no more than a few years old and should therefore be representative of the $\mathrm{C}$-isotope composition in the other study areas soon after recharge.

\section{References Cited}

Aeschbach-Hertig, W., Peeters, F., Beyerle, U., and Kipfer, R., 1999, Interpretation of dissolved atmospheric noble gases in natural waters: Water Resources Research, v. 35, no. 9, p. 2779-2792.

Aeschbach-Hertig, W., Peeters, F., Beyerle, U., and Kipfer, R., 2000, Paleotemperature reconstruction from noble gases in groundwater taking into account equilibrium with entrapped air: Nature, v. 405, p. 1040-1044.

Aldrich, L.T., Wetherill, G.W., Tilton, G.R., and Davis, G.L., 1956, The half-life of ${ }^{87} \mathrm{Rb}$ : Physical Reviews, v. 104, p. 1045-1047.

Clark, I., and Fritz, P., 1999, Environmental isotopes in hydrogeology - Tracing the carbon cycle: Boca Raton, Fla., CRC Press, 2d ed., p. 111-136. 
Coplen, T.B., 1994, Reporting of stable hydrogen, carbon, and oxygen isotopic abundances: Pure and Applied Chemistry, v. 66 , p. 273-276.

Craig, Harmon, 1961a, Isotopic variation in meteoric waters: Science, v. 133, p. 1702-1703.

Craig, Harmon, 1961b, Standard for reporting concentrations of deuterium and oxygen-18 in natural waters: Science, v. 133 , p. $1833-1834$.

Dansgaard, Willi, 1964, Stable isotopes in precipitation: Tellus, v. 16, p. 436-469.

Davis, S.N., Whittemore, D.O., Fahryka-Martin, J., 1998, Uses of chloride-bromide ratios in studies of potable water: Ground Water, v. 36, p. 338-350.

Degens, E.T., 1969, Biogeochemistry of stable carbon isotopes, chapter 12, in Eglinton, G., and Murphy, M.T.J., eds., Organic Geochemistry-Methods and Results: SpringerVerlag, N.Y., p. 304-329.

Freeze, R.A., and Cherry, J.A., 1979, Groundwater: Englewood Cliffs, N.J., Prentice-Hall, 64 p.

Friedman, Irving, and O’Neil, J.R., 1977, Compilation of stable isotope fractionation factors of geochemical interest, in Fleischer, M., ed., Data of geochemistry, chap. KK: U.S. Geological Survey Professional Paper 440-KK, 12 p., and 49 fig.

Friedman, Irving, Smith, G.I., Gleason, J.D., Warden, Augusta, and Harris, J.M., 1992, Stable isotope composition of waters in southeastern California-Modern precipitation: Journal of Geophysical Research, v. 97, p. 5795-5812.

Gleason, J.D., Veronda, G., Smith, G.I., Friedman, Irving, and Martin, Peter, 1994, Deuterium content of water from wells and perennial springs, southeastern California: U.S. Geological Survey Hydrologic Investigations Atlas HA-727.

Godwin, H., 1956, Half-life of radiocarbon: Nature, v. 195, p. 984.

Gonfiantini, R., 1978, Standards for stable isotope measurements in natural compounds: Nature, v. 271, p. 534-536.

Heaton, T.H.E., and Vogel, J.C., 1981, "Excess air” in groundwater: Journal of Hydrology, v. 50, p. 201-216.

Hem, J.D., 1989, Study and interpretation of the chemical characteristics of natural water ( $3 \mathrm{~d}$ ed.): U.S. Geological Survey Water-Supply Paper 2254, 263 p.

Ingraham, N.L., and Taylor, B.E., 1991, Light stable isotope systematics of large-scale hydrologic regimes in California and Nevada: Water Resources Research, v. 27, p. 77-90.
Izbicki, J.A., 1996, Seawater intrusion in a California coastal aquifer: U.S. Geological Survey Fact Sheet, FS-125-96, 4 p.

Izbicki, J.A., Borchers, J.W., Leighton, D.A., Kulongoski, Justin, Fields, Latoya, Galloway, D.L., and Michel, R.L., 2003, Hydrogeology and geochemistry of aquifers underlying the San Lorenzo and San Leandro area of the East Bay Plain, Alameda County, California: U.S. Geological Survey Water-Resources Investigations Report 02-4259, 86 p.

Land, Michael, Reichard, E.G., Crawford, S.M., Everett, R.R., Newhouse, M.W., and Williams, C.F., 2004, Ground-water quality of coastal aquifer systems in the West Coast Basin, Los Angeles County, California, 1999-2002: U.S. Geological Survey Scientific Investigations Report 2004-5067, $80 \mathrm{p}$.

Lucas, L.L., and Unterweger, M.P., 2000, Comprehensive review and critical evaluation of the half-life of tritium: Journal of Research of the National Institute of Standards and Technology, v. 105, p. 541-549.

Manning, A.H., and Solomon, D.K., 2003, Using noble gases to investigate mountain-front recharge: Journal of Hydrology, v. 275, p. 194-207.

Martin, Peter, ed., with contributions by Brandt, Justin, Catchings, R.D., Christensen, A.H., Flint, A.L., Gandhok, Gini, Goldman, M.R., Halford, K.J., Langenheim, V.E., Martin, Peter, Rymer, M.J., Schroeder, R.A., Smith, G.A., and Sneed, Michelle, 2011, The source, discharge, and chemical characteristics of water from Agua Caliente Spring, Palm Springs, California: U.S. Geological Survey Scientific Investigations Report 2011-5156, 106 p.

Mazor, Emanuel, 1991, Applied chemical and isotopic groundwater hydrology: Buckingham, England, Open University Press, 274 p.

Nishikawa, Tracy, Densmore, J.N., Martin, Peter, and Matti, Jonathan, 2003, Evaluation of the source and transport of high nitrate concentrations in ground water, Warren subbasin, California: U.S. Geological Survey Water-Resources Investigations Report 03-4009, 133 p.

Parkhurst, D.L., and Appelo, C.A.J., 1999, User's guide to PHREEQC (v. 2) - A computer program for speciation, batch-reaction, one-dimensional transport, and inverse geochemical calculations: U.S. Geological Survey WaterResources Investigations Report 99-4259, 310 p.

Piper, A.M., 1944, A graphic procedure in the geochemical interpretation of water analyses: American Geophysical Union Transactions, v. 25, p. 914-923. 
Rose, T.P., Davisson, M.L., and Criss, R.E., 1996, Isotope hydrology of voluminous cold springs in fractured rock from an active volcanic region, northeastern California: Journal of Hydrology, v. 179, p. 207-236.

Schroeder, R.A., Anders, R., Böhlke, J.K., Michel, R.L., and Metge, D.W., 1997, Water quality at production wells near artificial-recharge basins in Montebello Forebay, Los Angeles County, in Kendall, D.W., ed., Proceedings of the AWRA Symposium, Conjunctive Use of Water Resources: Aquifer Storage and Recovery, American Water Resources Association National Meeting, 33d, Long Beach, Calif., October 19-23, 1997: American Water Resources Association, Herndon, Virginia, TPS-97-2, p. 273-284.

Smith, G.I., Friedman, Irving, Gleason, J.D., and Warden, Augusta, 1992, Stable isotope composition of waters in southeastern California-Groundwaters and their relation to modern precipitation: Journal of Geophysical Research, v. 97. p. 5813-5823.

Stumm, Werner and Morgan, J.J., 1996, Aquatic chemistry, chemical equilibria and rates in natural waters ( $3 \mathrm{~d}$ ed.): New York, John Wiley and Sons, Inc., 1022 p.

Stute, Martin, and Schlosser, Peter, 2000, Atmospheric noble gases, in Cook, Peter, and Herezeg, A.L., eds., Environmental tracers in subsurface hydrology: Boston, Kluwer Academic Publishers, p. 349-377.

Taylor, C.B., and Roether, W., 1982, A uniform scale for reporting low-level tritium in water, in methods of low-level counting and spectrometry: Vienna, International Atomic Energy Agency, p. 303-323.

Turekian, K.K., and Wedepohl, K.H., 1961, Distribution of the elements in some major units of the Earth's crust: Geological Society of America Bulletin, v. 72, p. 175-182. 


\title{
Appendix 2. Historical Water-Quality Data, 1987-2000
}

\author{
By Roy A. Schroeder and Gregory Smith
}




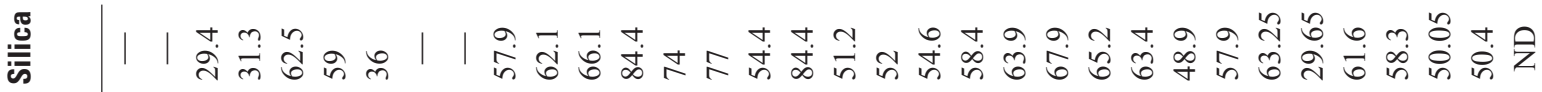

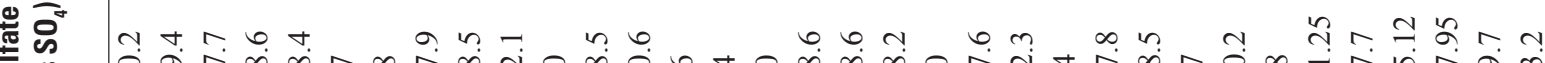

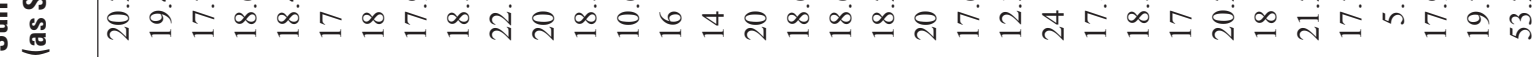
要

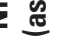

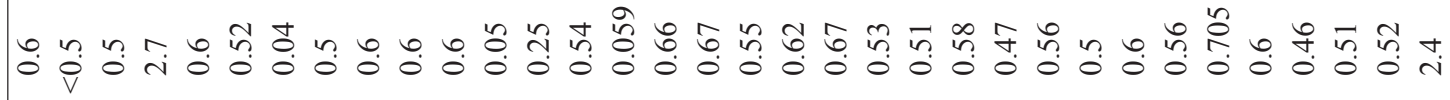

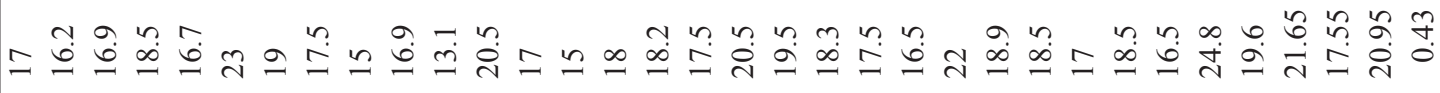

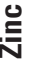

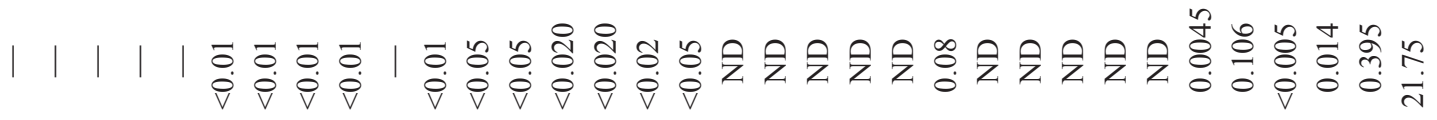

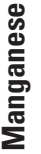

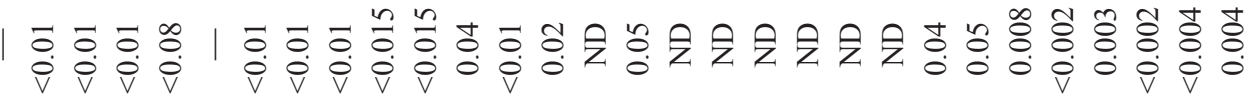

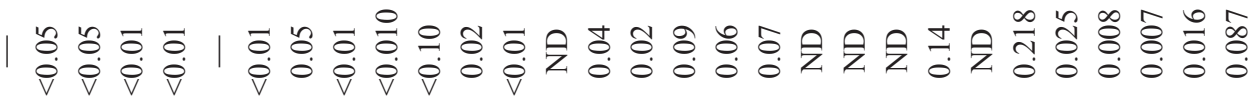

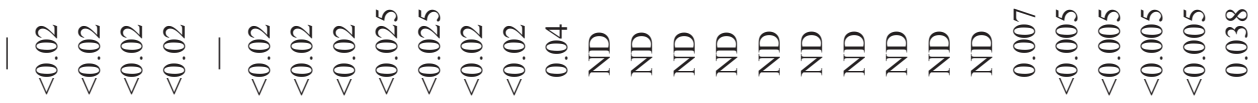
n-

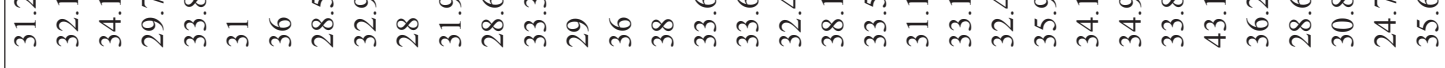

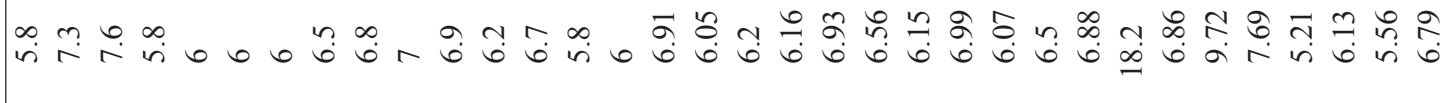

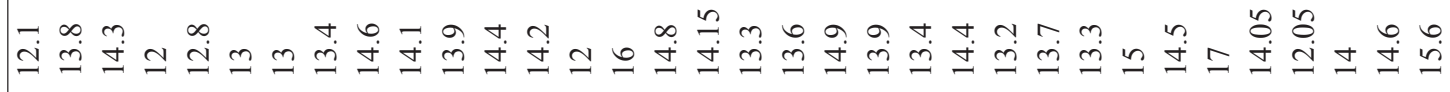

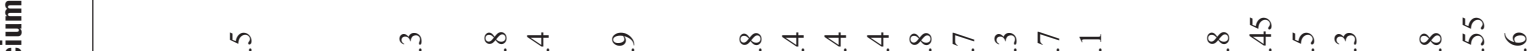
$\frac{0}{0}$

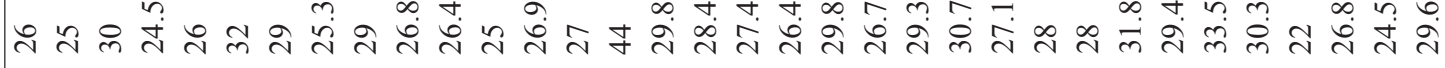

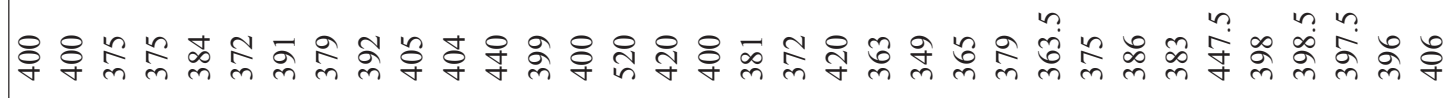
言管

$\infty 600 \overline{0}$

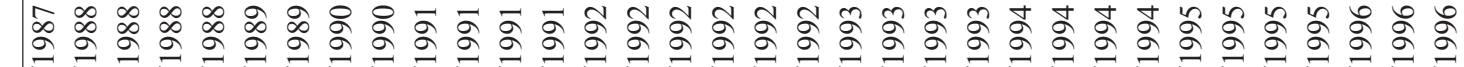
m

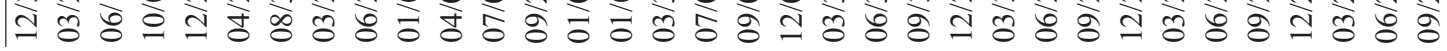




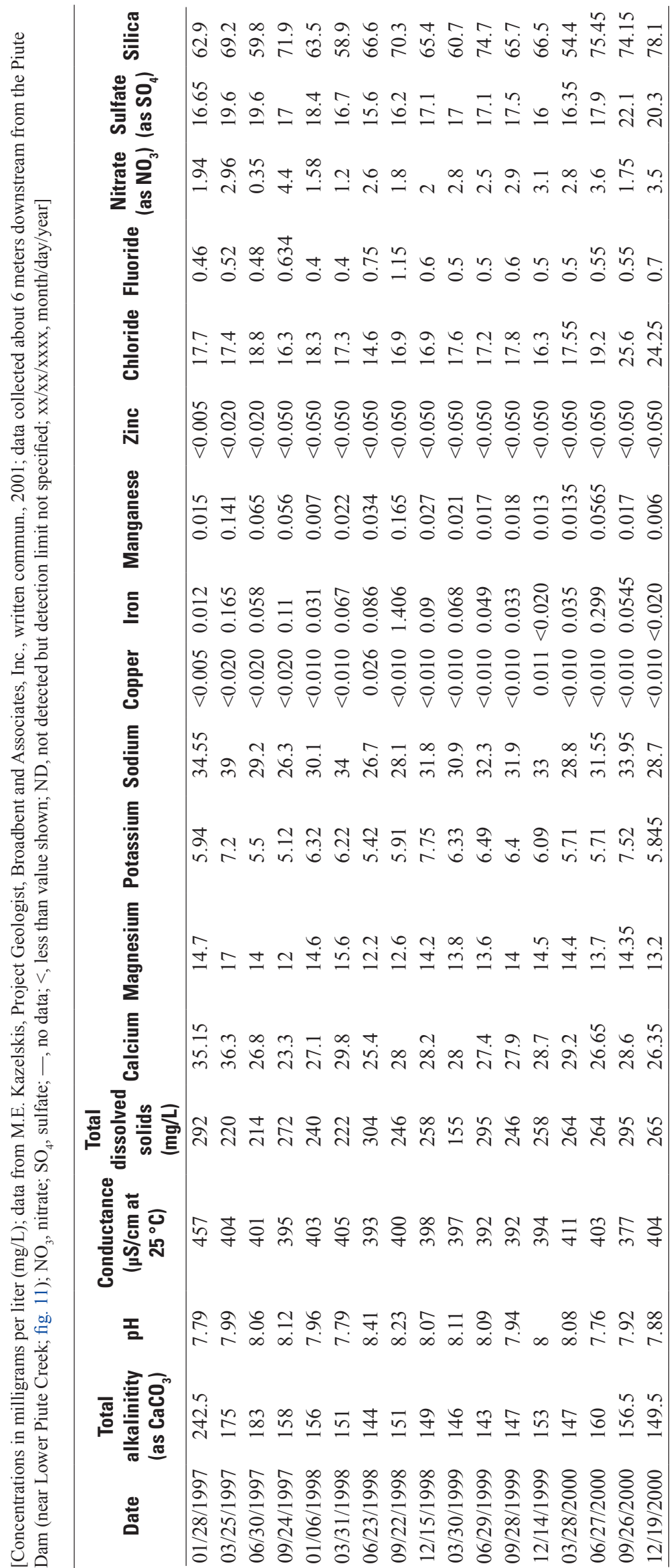


This page intentionally left blank. 


\section{Appendix 3. Location of Biological-Survey Reaches, 2005-06}

By Elizabeth Gallegos 


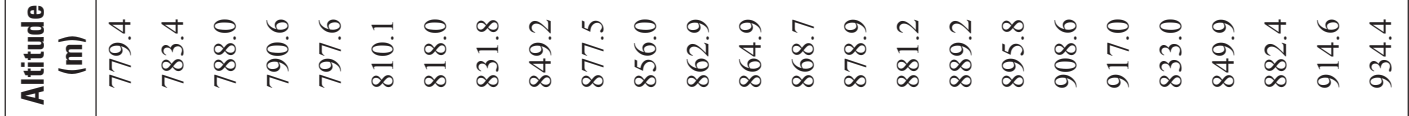

Е

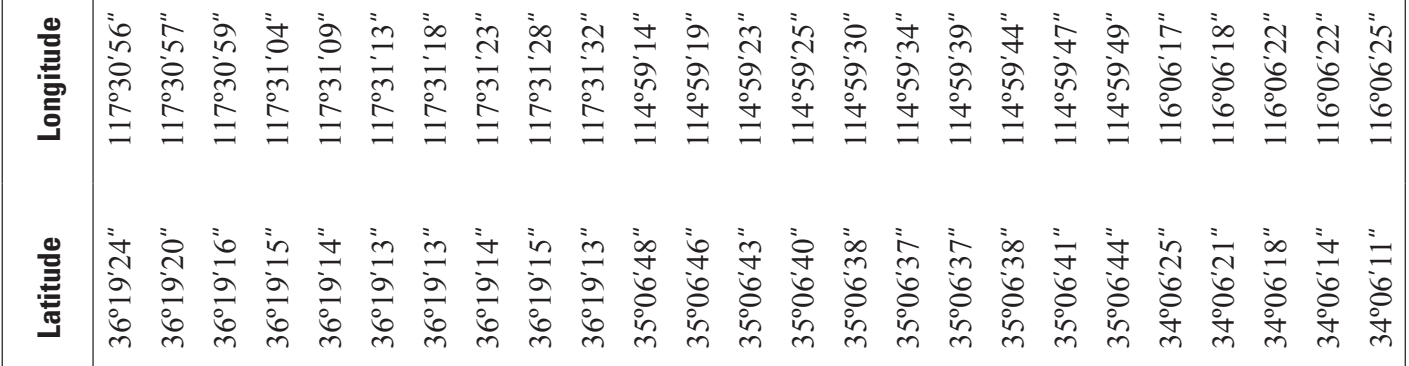

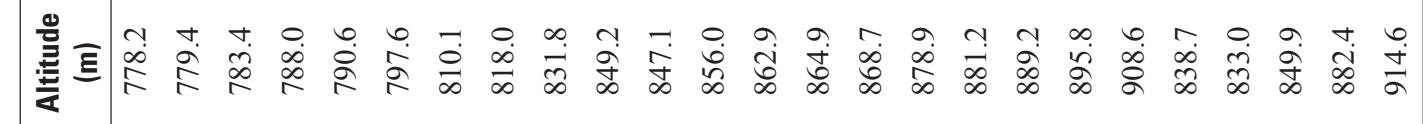

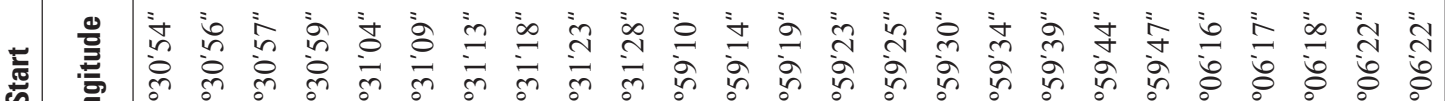

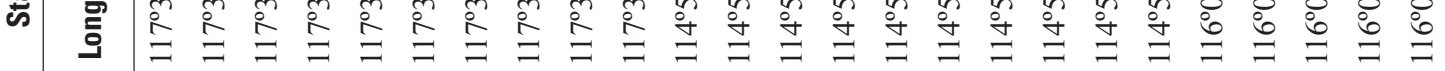

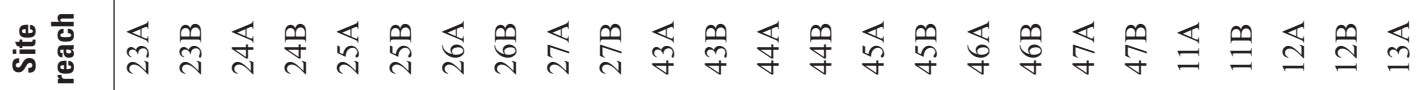

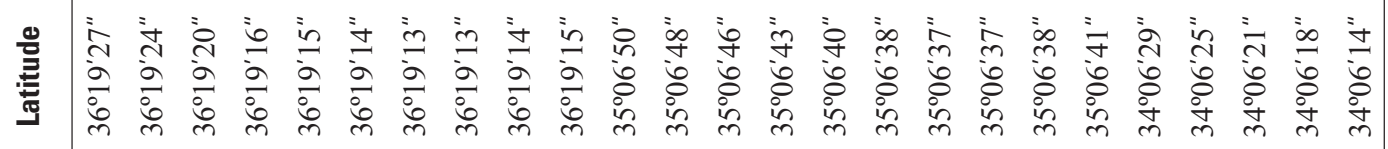




\section{Appendix 4. Location and Capture Information for Western Toads at Darwin Falls, Death Valley National Park, 1997-99}

By Elizabeth Gallegos 
Table 4-1. Location and capture information for western toads at Darwin Falls, Death Valley National Park, 1997-99.

[Data collected by Death Valley National Park personnel; latitude and longitude are presented in degrees, minutes, seconds, referenced to the North American Datum of 1983 (NAD 83); PIT, passive integrated transponder; xx/xx/xxxx, month/day/year]

\begin{tabular}{|c|c|c|c|c|c|c|c|}
\hline PIT tag no. & Capture date & Latitude & Longitude & PIT tag no. & Capture date & Latitude & Longitude \\
\hline 4062591211 & 11/02/1997 & $36^{\circ} 19^{\prime} 35^{\prime \prime}$ & $117^{\circ} 30^{\prime} 51^{\prime \prime}$ & 4062690020 & $03 / 22 / 1998$ & $36^{\circ} 19^{\prime} 27^{\prime \prime}$ & $117^{\circ} 30^{\prime} 55^{\prime \prime}$ \\
\hline 4062722471 & $11 / 02 / 1997$ & $36^{\circ} 19^{\prime} 25^{\prime \prime}$ & $117^{\circ} 30^{\prime} 56^{\prime \prime}$ & 4062724225 & $03 / 22 / 1998$ & $36^{\circ} 19^{\prime} 16^{\prime \prime}$ & $117^{\circ} 30^{\prime} 59^{\prime \prime}$ \\
\hline 4062785566 & $11 / 02 / 1997$ & $36^{\circ} 19^{\prime} 16^{\prime \prime}$ & $117^{\circ} 30^{\prime} 59^{\prime \prime}$ & 4062786335 & 03/22/1998 & $36^{\circ} 19^{\prime} 23^{\prime \prime}$ & $117^{\circ} 30^{\prime} 56^{\prime \prime}$ \\
\hline 1F552E2C32 & $11 / 02 / 1997$ & $36^{\circ} 19^{\prime} 16^{\prime \prime}$ & $117^{\circ} 31^{\prime} 00^{\prime \prime}$ & 4063020301 & 03/22/1998 & $36^{\circ} 19^{\prime} 31^{\prime \prime}$ & $117^{\circ} 30^{\prime} 53^{\prime \prime}$ \\
\hline 40625A7949 & $11 / 02 / 1997$ & $36^{\circ} 19^{\prime} 16^{\prime \prime}$ & $117^{\circ} 30^{\prime} 59^{\prime \prime}$ & 4063021765 & 03/22/1998 & $36^{\circ} 19^{\prime} 35^{\prime \prime}$ & $117^{\circ} 30^{\prime} 51^{\prime \prime}$ \\
\hline 40625D7815 & $11 / 02 / 1997$ & $36^{\circ} 19^{\prime} 16^{\prime \prime}$ & $117^{\circ} 31^{\prime} 04^{\prime \prime}$ & 1F504E6E55 & 03/22/1998 & $36^{\circ} 19^{\prime} 23^{\prime \prime}$ & $117^{\circ} 30^{\prime} 56^{\prime \prime}$ \\
\hline 40625E7E48 & $11 / 02 / 1997$ & $36^{\circ} 19^{\prime} 22^{\prime \prime}$ & $117^{\circ} 30^{\prime} 56^{\prime \prime}$ & $4062550 \mathrm{E} 68$ & 03/22/1998 & $36^{\circ} 19^{\prime} 23^{\prime \prime}$ & $117^{\circ} 30^{\prime} 56^{\prime \prime}$ \\
\hline $406260685 \mathrm{~F}$ & $11 / 02 / 1997$ & $36^{\circ} 19^{\prime} 34^{\prime \prime}$ & $117^{\circ} 30^{\prime} 51^{\prime \prime}$ & $4062563 \mathrm{~F} 45$ & 03/22/1998 & $36^{\circ} 19^{\prime} 20^{\prime \prime}$ & $117^{\circ} 30^{\prime} 56^{\prime \prime}$ \\
\hline $406262041 \mathrm{E}$ & $11 / 02 / 1997$ & $36^{\circ} 19^{\prime} 16^{\prime \prime}$ & $117^{\circ} 31^{\prime} 00^{\prime \prime}$ & 406258516B & $03 / 22 / 1998$ & $36^{\circ} 19^{\prime} 16^{\prime \prime}$ & $117^{\circ} 30^{\prime} 58^{\prime \prime}$ \\
\hline 40626B7B12 & $11 / 02 / 1997$ & $36^{\circ} 19^{\prime} 25^{\prime \prime}$ & $117^{\circ} 30^{\prime} 56^{\prime \prime}$ & $40625 \mathrm{~A} 444 \mathrm{~B}$ & 03/22/1998 & $36^{\circ} 19^{\prime} 16^{\prime \prime}$ & $117^{\circ} 31^{\prime} 04^{\prime \prime}$ \\
\hline 4062720A1A & $11 / 02 / 1997$ & $36^{\circ} 19^{\prime} 16^{\prime \prime}$ & $117^{\circ} 30^{\prime} 59^{\prime \prime}$ & $40625 \mathrm{C} 187 \mathrm{~B}$ & 03/22/1998 & $36^{\circ} 19^{\prime} 31^{\prime \prime}$ & $117^{\circ} 30^{\prime} 53^{\prime \prime}$ \\
\hline 4062784F6A & $11 / 02 / 1997$ & $36^{\circ} 19^{\prime} 24^{\prime \prime}$ & $117^{\circ} 30^{\prime} 56^{\prime \prime}$ & $40625 \mathrm{C} 3 \mathrm{~B} 6 \mathrm{~F}$ & $03 / 22 / 1998$ & $36^{\circ} 19^{\prime} 19^{\prime \prime}$ & $117^{\circ} 30^{\prime} 57^{\prime \prime}$ \\
\hline $406279535 \mathrm{C}$ & $11 / 02 / 1997$ & $36^{\circ} 19^{\prime} 18^{\prime \prime}$ & $117^{\circ} 30^{\prime} 57^{\prime \prime}$ & $40625 \mathrm{D} 0340$ & 03/22/1998 & $36^{\circ} 19^{\prime} 23^{\prime \prime}$ & $117^{\circ} 30^{\prime} 56^{\prime \prime}$ \\
\hline 40627A0C63 & $11 / 02 / 1997$ & $36^{\circ} 19^{\prime} 32^{\prime \prime}$ & $117^{\circ} 30^{\prime} 52^{\prime \prime}$ & 40625D4D51 & 03/22/1998 & $36^{\circ} 19^{\prime} 16^{\prime \prime}$ & $117^{\circ} 31^{\prime} 04^{\prime \prime}$ \\
\hline $40627 \mathrm{C} 3510$ & $11 / 02 / 1997$ & $36^{\circ} 19^{\prime} 25^{\prime \prime}$ & $117^{\circ} 30^{\prime} 56^{\prime \prime}$ & 40625D5A22 & 03/22/1998 & $36^{\circ} 19^{\prime} 28^{\prime \prime}$ & $117^{\circ} 30^{\prime} 55^{\prime \prime}$ \\
\hline 4062730771 & $11 / 08 / 1997$ & $36^{\circ} 19^{\prime} 32^{\prime \prime}$ & $117^{\circ} 30^{\prime} 52^{\prime \prime}$ & $40625 \mathrm{E} 6 \mathrm{C} 02$ & 03/22/1998 & $36^{\circ} 19^{\prime} 17^{\prime \prime}$ & $117^{\circ} 30^{\prime} 58^{\prime \prime}$ \\
\hline 4062544F26 & $11 / 08 / 1997$ & $36^{\circ} 19^{\prime} 16^{\prime \prime}$ & $117^{\circ} 30^{\prime} 59^{\prime \prime}$ & $40625 \mathrm{~F} 104 \mathrm{E}$ & 03/22/1998 & $36^{\circ} 19^{\prime} 21^{\prime \prime}$ & $117^{\circ} 30^{\prime} 56^{\prime \prime}$ \\
\hline 40625E051D & $11 / 08 / 1997$ & $36^{\circ} 19^{\prime} 24^{\prime \prime}$ & $117^{\circ} 30^{\prime} 56^{\prime \prime}$ & 40625F7B65 & 03/22/1998 & $36^{\circ} 19^{\prime} 16^{\prime \prime}$ & $117^{\circ} 31^{\prime} 04^{\prime \prime}$ \\
\hline 40626B4329 & $11 / 08 / 1997$ & $36^{\circ} 19^{\prime} 16^{\prime \prime}$ & $117^{\circ} 31^{\prime} 01^{\prime \prime}$ & 4062604A68 & $03 / 22 / 1998$ & $36^{\circ} 19^{\prime} 23^{\prime \prime}$ & $117^{\circ} 30^{\prime} 56^{\prime \prime}$ \\
\hline $4062701 C 2 D$ & $11 / 08 / 1997$ & $36^{\circ} 19^{\prime} 17^{\prime \prime}$ & $117^{\circ} 30^{\prime} 58^{\prime \prime}$ & $4062610 \mathrm{~F} 3 \mathrm{C}$ & 03/22/1998 & $36^{\circ} 19^{\prime} 16^{\prime \prime}$ & $117^{\circ} 31^{\prime} 04^{\prime \prime}$ \\
\hline 40627A0611 & $11 / 08 / 1997$ & $36^{\circ} 19^{\prime} 16^{\prime \prime}$ & $117^{\circ} 31^{\prime} 00^{\prime \prime}$ & $4062643 \mathrm{C} 4 \mathrm{E}$ & 03/22/1998 & $36^{\circ} 19^{\prime} 16^{\prime \prime}$ & $117^{\circ} 31^{\prime} 04^{\prime \prime}$ \\
\hline 40627B533B & $11 / 08 / 1997$ & $36^{\circ} 19^{\prime} 29^{\prime \prime}$ & $117^{\circ} 30^{\prime} 54^{\prime \prime}$ & $4062697 \mathrm{C} 78$ & $03 / 22 / 1998$ & $36^{\circ} 19^{\prime} 18^{\prime \prime}$ & $117^{\circ} 30^{\prime} 57^{\prime \prime}$ \\
\hline 4062553918 & 03/21/1998 & $36^{\circ} 19^{\prime} 16^{\prime \prime}$ & $117^{\circ} 31^{\prime} 01^{\prime \prime}$ & 40626B1500 & 03/22/1998 & $36^{\circ} 19^{\prime} 16^{\prime \prime}$ & $117^{\circ} 31^{\prime} 04^{\prime \prime}$ \\
\hline 4062722766 & 03/21/1998 & $36^{\circ} 19^{\prime} 16^{\prime \prime}$ & $117^{\circ} 31^{\prime} 01^{\prime \prime}$ & $40626 \mathrm{~B} 4610$ & 03/22/1998 & $36^{\circ} 19^{\prime} 16^{\prime \prime}$ & $117^{\circ} 31^{\prime} 04^{\prime \prime}$ \\
\hline 4063001536 & 03/21/1998 & $36^{\circ} 19^{\prime} 20^{\prime \prime}$ & $117^{\circ} 30^{\prime} 56^{\prime \prime}$ & 40626B4B6F & $03 / 22 / 1998$ & $36^{\circ} 19^{\prime} 31^{\prime \prime}$ & $117^{\circ} 30^{\prime} 53^{\prime \prime}$ \\
\hline $40625 \mathrm{~A} 3930$ & 03/21/1998 & $36^{\circ} 19^{\prime} 32^{\prime \prime}$ & $117^{\circ} 30^{\prime} 52^{\prime \prime}$ & $40626 \mathrm{C} 0 \mathrm{~B} 69$ & $03 / 22 / 1998$ & $36^{\circ} 19^{\prime} 16^{\prime \prime}$ & $117^{\circ} 31^{\prime} 01^{\prime \prime}$ \\
\hline 40625F5952 & 03/21/1998 & $36^{\circ} 19^{\prime} 16^{\prime \prime}$ & $117^{\circ} 30^{\prime} 59^{\prime \prime}$ & 40626D1937 & 03/22/1998 & $36^{\circ} 19^{\prime} 16^{\prime \prime}$ & $117^{\circ} 31^{\prime} 00^{\prime \prime}$ \\
\hline $406262741 \mathrm{~A}$ & 03/21/1998 & $36^{\circ} 19^{\prime} 16^{\prime \prime}$ & $117^{\circ} 31^{\prime} 01^{\prime \prime}$ & $40626 \mathrm{~F} 0 \mathrm{C} 17$ & 03/22/1998 & $36^{\circ} 19^{\prime} 17^{\prime \prime}$ & $117^{\circ} 30^{\prime} 58^{\prime \prime}$ \\
\hline 40626A075E & 03/21/1998 & $36^{\circ} 19^{\prime} 16^{\prime \prime}$ & $117^{\circ} 30^{\prime} 59^{\prime \prime}$ & $40626 \mathrm{~F} 373 \mathrm{~B}$ & $03 / 22 / 1998$ & $36^{\circ} 19^{\prime} 16^{\prime \prime}$ & $117^{\circ} 31^{\prime} 04^{\prime \prime}$ \\
\hline 40626B4C62 & 03/21/1998 & $36^{\circ} 19^{\prime} 16^{\prime \prime}$ & $117^{\circ} 31^{\prime} 00^{\prime \prime}$ & 4062702A7E & 03/22/1998 & $36^{\circ} 19^{\prime} 30^{\prime \prime}$ & $117^{\circ} 30^{\prime} 54^{\prime \prime}$ \\
\hline 40626B7926 & 03/21/1998 & $36^{\circ} 19^{\prime} 25^{\prime \prime}$ & $117^{\circ} 30^{\prime} 56^{\prime \prime}$ & $4062722 \mathrm{C} 37$ & $03 / 22 / 1998$ & $36^{\circ} 19^{\prime} 16^{\prime \prime}$ & $117^{\circ} 31^{\prime} 04^{\prime \prime}$ \\
\hline 406273153B & 03/21/1998 & $36^{\circ} 19^{\prime} 16^{\prime \prime}$ & $117^{\circ} 30^{\prime} 58^{\prime \prime}$ & $406273083 \mathrm{~A}$ & 03/22/1998 & $36^{\circ} 19^{\prime} 16^{\prime \prime}$ & $117^{\circ} 30^{\prime} 59^{\prime \prime}$ \\
\hline 4062737A0A & 03/21/1998 & $36^{\circ} 19^{\prime} 16^{\prime \prime}$ & $117^{\circ} 30^{\prime} 59^{\prime \prime}$ & $4062730 \mathrm{C} 20$ & $03 / 22 / 1998$ & $36^{\circ} 19^{\prime} 16^{\prime \prime}$ & $117^{\circ} 30^{\prime} 59^{\prime \prime}$ \\
\hline $406274053 \mathrm{~A}$ & 03/21/1998 & $36^{\circ} 19^{\prime} 22^{\prime \prime}$ & $117^{\circ} 30^{\prime} 56^{\prime \prime}$ & $4062730 \mathrm{E} 14$ & 03/22/1998 & $36^{\circ} 19^{\prime} 16^{\prime \prime}$ & $117^{\circ} 31^{\prime} 04^{\prime \prime}$ \\
\hline 4062740D7C & 03/21/1998 & $36^{\circ} 19^{\prime} 33^{\prime \prime}$ & $117^{\circ} 30^{\prime} 52^{\prime \prime}$ & 4062761B4B & $03 / 22 / 1998$ & $36^{\circ} 19^{\prime} 16^{\prime \prime}$ & $117^{\circ} 31^{\prime} 04^{\prime \prime}$ \\
\hline $4062765 \mathrm{D} 1 \mathrm{C}$ & 03/21/1998 & $36^{\circ} 19^{\prime} 16^{\prime \prime}$ & $117^{\circ} 31^{\prime} 01^{\prime \prime}$ & $4062773 \mathrm{E} 65$ & 03/22/1998 & $36^{\circ} 19^{\prime} 16^{\prime \prime}$ & $117^{\circ} 31^{\prime} 04^{\prime \prime}$ \\
\hline 40627A6C19 & 03/21/1998 & $36^{\circ} 19^{\prime} 18^{\prime \prime}$ & $117^{\circ} 30^{\prime} 57^{\prime \prime}$ & $406279004 \mathrm{C}$ & 03/22/1998 & $36^{\circ} 19^{\prime} 28^{\prime \prime}$ & $117^{\circ} 30^{\prime} 55^{\prime \prime}$ \\
\hline 406302382D & 03/21/1998 & $36^{\circ} 19^{\prime} 16^{\prime \prime}$ & $117^{\circ} 31^{\prime} 01^{\prime \prime}$ & $406279361 \mathrm{~F}$ & $03 / 22 / 1998$ & $36^{\circ} 19^{\prime} 29^{\prime \prime}$ & $117^{\circ} 30^{\prime} 54^{\prime \prime}$ \\
\hline 4062567077 & 03/22/1998 & $36^{\circ} 19^{\prime} 16^{\prime \prime}$ & $117^{\circ} 30^{\prime} 59^{\prime \prime}$ & 40627A5D47 & 03/22/1998 & $36^{\circ} 19^{\prime} 32^{\prime \prime}$ & $117^{\circ} 30^{\prime} 52^{\prime \prime}$ \\
\hline 4062581508 & 03/22/1998 & $36^{\circ} 19^{\prime} 16^{\prime \prime}$ & $117^{\circ} 31^{\prime} 02^{\prime \prime}$ & $40627 \mathrm{C} 3 \mathrm{~A} 5 \mathrm{~B}$ & $03 / 22 / 1998$ & $36^{\circ} 19^{\prime} 16^{\prime \prime}$ & $117^{\circ} 31^{\prime} 03^{\prime \prime}$ \\
\hline 4062592442 & 03/22/1998 & $36^{\circ} 19^{\prime} 17^{\prime \prime}$ & $117^{\circ} 30^{\prime} 57^{\prime \prime}$ & $40627 \mathrm{C} 410 \mathrm{E}$ & 03/22/1998 & $36^{\circ} 19^{\prime} 16^{\prime \prime}$ & $117^{\circ} 31^{\prime} 04^{\prime \prime}$ \\
\hline 4062643977 & 03/22/1998 & $36^{\circ} 19^{\prime} 17^{\prime \prime}$ & $117^{\circ} 30^{\prime} 57^{\prime \prime}$ & 40627D0806 & 03/22/1998 & $36^{\circ} 19^{\prime} 16^{\prime \prime}$ & $117^{\circ} 30^{\prime} 59^{\prime \prime}$ \\
\hline
\end{tabular}


Table 4-1. Location and capture information for western toads at Darwin Falls, Death Valley National Park, 1997-99._Continued

[Data collected by Death Valley National Park personnel; latitude and longitude are presented in degrees, minutes, seconds, referenced to the North American Datum of 1983 (NAD 83); PIT, passive integrated transponder; xx/xx/xxxx, month/day/year]

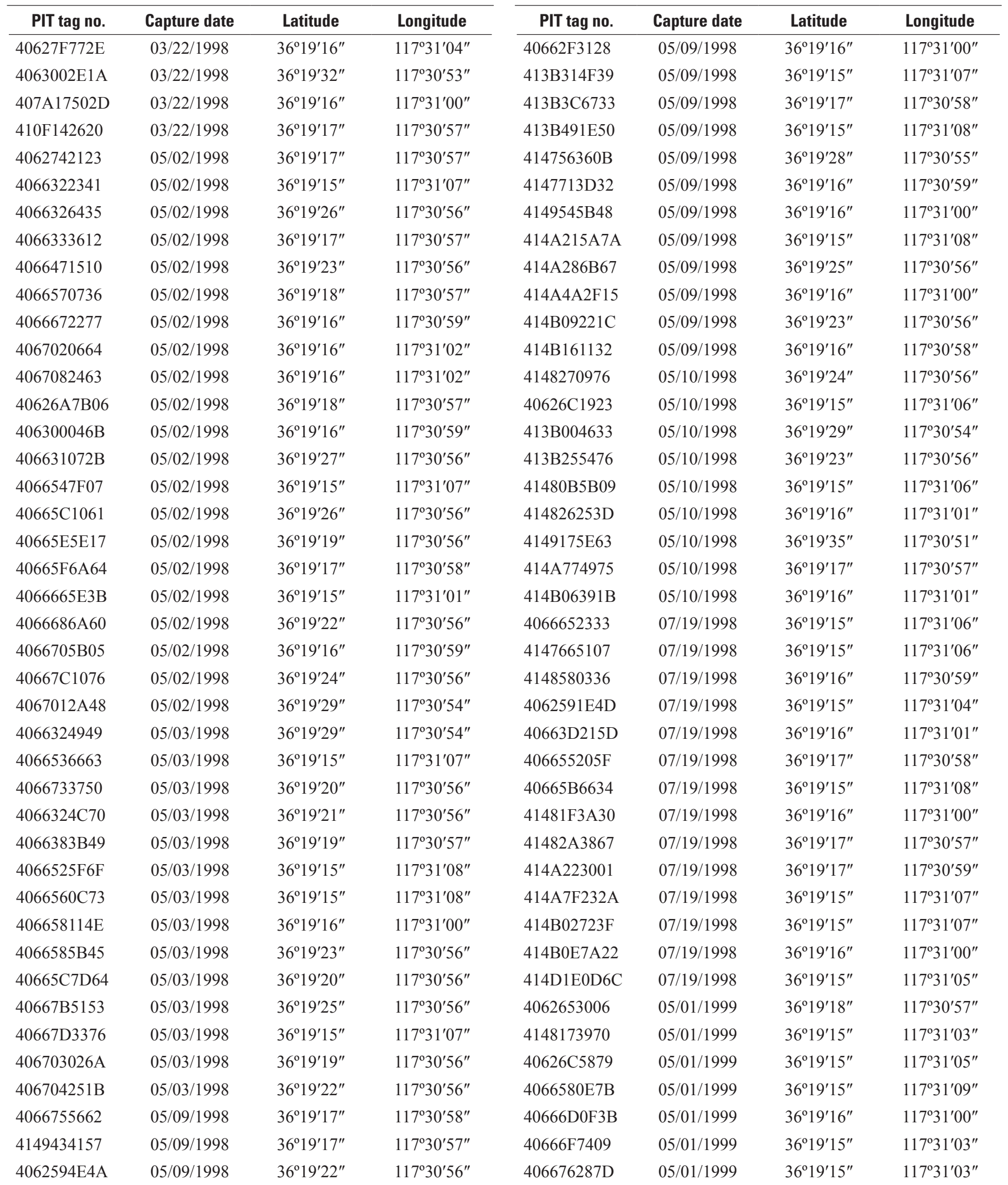


Table 4-1. Location and capture information for western toads at Darwin Falls, Death Valley National Park, 1997-99.-Continued

[Data collected by Death Valley National Park personnel; latitude and longitude are presented in degrees, minutes, seconds, referenced to the North American Datum of 1983 (NAD 83); PIT, passive integrated transponder; xx/xx/xxxx, month/day/year]

\begin{tabular}{|c|c|c|c|c|c|c|c|}
\hline PIT tag no. & Capture date & Latitude & Longitude & PIT tag no. & Capture date & Latitude & Longitude \\
\hline 406703205D & 05/01/1999 & $36^{\circ} 19^{\prime} 16^{\prime \prime}$ & $117^{\circ} 30^{\prime} 59^{\prime \prime}$ & 41485B4431 & $05 / 02 / 1999$ & $36^{\circ} 19^{\prime} 16^{\prime \prime}$ & $117^{\circ} 31^{\prime} 04^{\prime \prime}$ \\
\hline 413B243967 & 05/01/1999 & $36^{\circ} 19^{\prime} 26^{\prime \prime}$ & $117^{\circ} 30^{\prime} 56^{\prime \prime}$ & $4148604 \mathrm{~F} 3 \mathrm{~F}$ & 05/02/1999 & $36^{\circ} 19^{\prime} 26^{\prime \prime}$ & $117^{\circ} 30^{\prime} 56^{\prime \prime}$ \\
\hline 413B2A4737 & 05/01/1999 & $36^{\circ} 19^{\prime} 19^{\prime \prime}$ & $117^{\circ} 30^{\prime} 57^{\prime \prime}$ & 4148664E77 & 05/02/1999 & $36^{\circ} 19^{\prime} 15^{\prime \prime}$ & $117^{\circ} 31^{\prime} 01^{\prime \prime}$ \\
\hline 413В3С6878 & 05/01/1999 & $36^{\circ} 19^{\prime} 20^{\prime \prime}$ & $117^{\circ} 30^{\prime} 56^{\prime \prime}$ & 41492D387C & 05/02/1999 & $36^{\circ} 19^{\prime} 16^{\prime \prime}$ & $117^{\circ} 30^{\prime} 59^{\prime \prime}$ \\
\hline 413B3D1F65 & 05/01/1999 & $36^{\circ} 19^{\prime} 15^{\prime \prime}$ & $117^{\circ} 31^{\prime} 01^{\prime \prime}$ & $41494 C 2943$ & 05/02/1999 & $36^{\circ} 19^{\prime} 19^{\prime \prime}$ & $117^{\circ} 30^{\prime} 57^{\prime \prime}$ \\
\hline 413B4A2036 & 05/01/1999 & $36^{\circ} 19^{\prime} 16^{\prime \prime}$ & $117^{\circ} 31^{\prime} 00^{\prime \prime}$ & $414 \mathrm{~A} 434144$ & 05/02/1999 & $36^{\circ} 19^{\prime} 15^{\prime \prime}$ & $117^{\circ} 31^{\prime} 04^{\prime \prime}$ \\
\hline 41420C3E48 & 05/01/1999 & $36^{\circ} 19^{\prime} 19^{\prime \prime}$ & $117^{\circ} 30^{\prime} 57^{\prime \prime}$ & $414 \mathrm{~A} 570 \mathrm{C} 22$ & 05/02/1999 & $36^{\circ} 19^{\prime} 17^{\prime \prime}$ & $117^{\circ} 30^{\prime} 57^{\prime \prime}$ \\
\hline 41436F503B & 05/01/1999 & $36^{\circ} 19^{\prime} 19^{\prime \prime}$ & $117^{\circ} 30^{\prime} 57^{\prime \prime}$ & 414B062234 & 05/02/1999 & $36^{\circ} 19^{\prime} 20^{\prime \prime}$ & $117^{\circ} 30^{\prime} 56^{\prime \prime}$ \\
\hline $414800091 \mathrm{E}$ & 05/01/1999 & $36^{\circ} 19^{\prime} 16^{\prime \prime}$ & $117^{\circ} 31^{\prime} 04^{\prime \prime}$ & 411D057945 & 05/08/1999 & $36^{\circ} 19^{\prime} 15^{\prime \prime}$ & $117^{\circ} 31^{\prime} 05^{\prime \prime}$ \\
\hline 41483E0D43 & 05/01/1999 & $36^{\circ} 19^{\prime} 15^{\prime \prime}$ & $117^{\circ} 31^{\prime} 03^{\prime \prime}$ & 411D0B1371 & 05/08/1999 & $36^{\circ} 19^{\prime} 19^{\prime \prime}$ & $117^{\circ} 30^{\prime} 57^{\prime \prime}$ \\
\hline 41484E393E & 05/01/1999 & $36^{\circ} 19^{\prime} 16^{\prime \prime}$ & $117^{\circ} 31^{\prime} 04^{\prime \prime}$ & 411D0B701C & 05/08/1999 & $36^{\circ} 19^{\prime} 16^{\prime \prime}$ & $117^{\circ} 30^{\prime} 59^{\prime \prime}$ \\
\hline 414928593D & 05/01/1999 & $36^{\circ} 19^{\prime} 16^{\prime \prime}$ & $117^{\circ} 31^{\prime} 04^{\prime \prime}$ & 411D0C0902 & 05/08/1999 & $36^{\circ} 19^{\prime} 16^{\prime \prime}$ & $117^{\circ} 30^{\prime} 59^{\prime \prime}$ \\
\hline 414A3F6211 & 05/01/1999 & $36^{\circ} 19^{\prime} 15^{\prime \prime}$ & $117^{\circ} 31^{\prime} 01^{\prime \prime}$ & 411D136059 & 05/08/1999 & $36^{\circ} 19^{\prime} 19^{\prime \prime}$ & $117^{\circ} 30^{\prime} 56^{\prime \prime}$ \\
\hline 414A624822 & 05/01/1999 & $36^{\circ} 19^{\prime} 16^{\prime \prime}$ & $117^{\circ} 30^{\prime} 59^{\prime \prime}$ & 411D163F0D & 05/08/1999 & $36^{\circ} 19^{\prime} 15^{\prime \prime}$ & $117^{\circ} 31^{\prime} 05^{\prime \prime}$ \\
\hline 414A631D08 & 05/01/1999 & $36^{\circ} 19^{\prime} 16^{\prime \prime}$ & $117^{\circ} 31^{\prime} 04^{\prime \prime}$ & 411D195F5F & 05/08/1999 & $36^{\circ} 19^{\prime} 19^{\prime \prime}$ & $117^{\circ} 30^{\prime} 57^{\prime \prime}$ \\
\hline 414A633832 & 05/01/1999 & $36^{\circ} 19^{\prime} 25^{\prime \prime}$ & $117^{\circ} 30^{\prime} 56^{\prime \prime}$ & 411D197A65 & 05/08/1999 & $36^{\circ} 19^{\prime} 17^{\prime \prime}$ & $117^{\circ} 30^{\prime} 57^{\prime \prime}$ \\
\hline 414B180F18 & 05/01/1999 & $36^{\circ} 19^{\prime} 18^{\prime \prime}$ & $117^{\circ} 30^{\prime} 57^{\prime \prime}$ & 411D271604 & 05/08/1999 & $36^{\circ} 19^{\prime} 15^{\prime \prime}$ & $117^{\circ} 31^{\prime} 07^{\prime \prime}$ \\
\hline 4066500167 & 05/02/1999 & $36^{\circ} 19^{\prime} 17^{\prime \prime}$ & $117^{\circ} 30^{\prime} 57^{\prime \prime}$ & $411 \mathrm{D} 2 \mathrm{C} 1848$ & 05/08/1999 & $36^{\circ} 19^{\prime} 20^{\prime \prime}$ & $117^{\circ} 30^{\prime} 57^{\prime \prime}$ \\
\hline 4066785003 & 05/02/1999 & $36^{\circ} 19^{\prime} 16^{\prime \prime}$ & $117^{\circ} 30^{\prime} 59^{\prime \prime}$ & $411 \mathrm{D} 2 \mathrm{C} 3 \mathrm{~B} 5 \mathrm{C}$ & 05/08/1999 & $36^{\circ} 19^{\prime} 17^{\prime \prime}$ & $117^{\circ} 30^{\prime} 57^{\prime \prime}$ \\
\hline 4148014222 & 05/02/1999 & $36^{\circ} 19^{\prime} 15^{\prime \prime}$ & $117^{\circ} 31^{\prime} 06^{\prime \prime}$ & 411D2E614E & 05/08/1999 & $36^{\circ} 19^{\prime} 17^{\prime \prime}$ & $117^{\circ} 30^{\prime} 58^{\prime \prime}$ \\
\hline 4148687567 & 05/02/1999 & $36^{\circ} 19^{\prime} 17^{\prime \prime}$ & $117^{\circ} 30^{\prime} 57^{\prime \prime}$ & 411D301039 & 05/08/1999 & $36^{\circ} 19^{\prime} 15^{\prime \prime}$ & $117^{\circ} 31^{\prime} 06^{\prime \prime}$ \\
\hline 4149176658 & 05/02/1999 & $36^{\circ} 19^{\prime} 15^{\prime \prime}$ & $117^{\circ} 31^{\prime} 05^{\prime \prime}$ & 411D311C71 & 05/08/1999 & $36^{\circ} 19^{\prime} 19^{\prime \prime}$ & $117^{\circ} 30^{\prime} 56^{\prime \prime}$ \\
\hline 413B05441F & 05/02/1999 & $36^{\circ} 19^{\prime} 18^{\prime \prime}$ & $117^{\circ} 30^{\prime} 56^{\prime \prime}$ & 411B697212 & 05/09/1999 & $36^{\circ} 19^{\prime} 16^{\prime \prime}$ & $117^{\circ} 31^{\prime} 01^{\prime \prime}$ \\
\hline 413B17323E & 05/02/1999 & $36^{\circ} 19^{\prime} 15^{\prime \prime}$ & $117^{\circ} 31^{\prime} 07^{\prime \prime}$ & 411D19752E & 05/09/1999 & $36^{\circ} 19^{\prime} 15^{\prime \prime}$ & $117^{\circ} 31^{\prime} 05^{\prime \prime}$ \\
\hline 413B1D0273 & 05/02/1999 & $36^{\circ} 19^{\prime} 17^{\prime \prime}$ & $117^{\circ} 30^{\prime} 58^{\prime \prime}$ & 411D1D0631 & 05/09/1999 & $36^{\circ} 19^{\prime} 23^{\prime \prime}$ & $117^{\circ} 30^{\prime} 56^{\prime \prime}$ \\
\hline 413B547904 & 05/02/1999 & $36^{\circ} 19^{\prime} 15^{\prime \prime}$ & $117^{\circ} 31^{\prime} 04^{\prime \prime}$ & 411D303737 & 05/09/1999 & $36^{\circ} 19^{\prime} 15^{\prime \prime}$ & $117^{\circ} 31^{\prime} 03^{\prime \prime}$ \\
\hline 413B555E1E & 05/02/1999 & $36^{\circ} 19^{\prime} 16^{\prime \prime}$ & $117^{\circ} 30^{\prime} 59^{\prime \prime}$ & 411D355676 & 05/09/1999 & $36^{\circ} 19^{\prime} 15^{\prime \prime}$ & $117^{\circ} 31^{\prime} 06^{\prime \prime}$ \\
\hline 41477B1A0C & 05/02/1999 & $36^{\circ} 19^{\prime} 22^{\prime \prime}$ & $117^{\circ} 30^{\prime} 56^{\prime \prime}$ & $411 \mathrm{D} 244670$ & 07/28/1999 & $36^{\circ} 19^{\prime} 16^{\prime \prime}$ & $117^{\circ} 30^{\prime} 59^{\prime \prime}$ \\
\hline 41477D6132 & 05/02/1999 & $36^{\circ} 19^{\prime} 15^{\prime \prime}$ & $117^{\circ} 31^{\prime} 05^{\prime \prime}$ & 414952431B & 07/28/1999 & $36^{\circ} 19^{\prime} 17^{\prime \prime}$ & $117^{\circ} 30^{\prime} 57^{\prime \prime}$ \\
\hline 41481B2E58 & 05/02/1999 & $36^{\circ} 19^{\prime} 15^{\prime \prime}$ & $117^{\circ} 31^{\prime} 01^{\prime \prime}$ & 4063001536 & 07/31/1999 & $36^{\circ} 19^{\prime} 17^{\prime \prime}$ & $117^{\circ} 30^{\prime} 58^{\prime \prime}$ \\
\hline
\end{tabular}




\section{Appendix 5. Location and Capture Information for Western Toads at Darwin Falls, Death Valley National Park, 2005}

By Elizabeth Gallegos 
Table 5-1. Location and capture information for western toads at Darwin Falls, Death Valley National Park, 2005.

[Data collected by U.S. Geological Survey personnel; latitude and longitude are presented in degrees, minutes, seconds, referenced to the North American Datum of 1983 (NAD 83); PIT, passive integrated transponder; xx/xx/xxxx, month/day/year]

\begin{tabular}{|c|c|c|c|c|c|c|c|c|c|}
\hline $\begin{array}{c}\text { PIT } \\
\operatorname{tag} \text { no. }\end{array}$ & $\begin{array}{c}\text { Capture } \\
\text { date }\end{array}$ & Latitude & Longitude & Sex & $\begin{array}{c}\text { PIT } \\
\text { tag no. }\end{array}$ & $\begin{array}{c}\text { Capture } \\
\text { date }\end{array}$ & Latitude & Longitude & Sex \\
\hline 055066054 & $05 / 11 / 2005$ & $36^{\circ} 19^{\prime} 27^{\prime \prime}$ & $117^{\circ} 30^{\prime} 55^{\prime \prime}$ & male & 062625614 & $06 / 08 / 2005$ & $36^{\circ} 19^{\prime} 19^{\prime \prime}$ & $117^{\circ} 30^{\prime} 57^{\prime \prime}$ & male \\
\hline 054886072 & $05 / 11 / 2005$ & $36^{\circ} 19^{\prime} 15^{\prime \prime}$ & $117^{\circ} 31^{\prime} 27^{\prime \prime}$ & male & 062618819 & $06 / 08 / 2005$ & $36^{\circ} 19^{\prime} 18^{\prime \prime}$ & $117^{\circ} 30^{\prime} 56^{\prime \prime}$ & male \\
\hline 054116281 & $05 / 11 / 2005$ & $36^{\circ} 19^{\prime} 15^{\prime \prime}$ & $117^{\circ} 31^{\prime} 26^{\prime \prime}$ & male & 062607772 & 06/08/2005 & $36^{\circ} 19^{\prime} 18^{\prime \prime}$ & $117^{\circ} 30^{\prime} 57^{\prime \prime}$ & male \\
\hline 053861300 & $05 / 11 / 2005$ & $36^{\circ} 19^{\prime} 15^{\prime \prime}$ & $117^{\circ} 31^{\prime} 26^{\prime \prime}$ & female & 062623279 & 06/08/2005 & $36^{\circ} 19^{\prime} 18^{\prime \prime}$ & $117^{\circ} 30^{\prime} 57^{\prime \prime}$ & male \\
\hline 055294024 & $05 / 11 / 2005$ & $36^{\circ} 19^{\prime} 15^{\prime \prime}$ & $117^{\circ} 31^{\prime} 26^{\prime \prime}$ & male & 062621382 & 06/08/2005 & $36^{\circ} 19^{\prime} 18^{\prime \prime}$ & $117^{\circ} 30^{\prime} 57^{\prime \prime}$ & male \\
\hline 054302859 & $05 / 11 / 2005$ & $36^{\circ} 19^{\prime} 16^{\prime \prime}$ & $117^{\circ} 31^{\prime} 23^{\prime \prime}$ & male & 062626336 & 06/08/2005 & $36^{\circ} 19^{\prime} 18^{\prime \prime}$ & $117^{\circ} 30^{\prime} 56^{\prime \prime}$ & female \\
\hline 054022339 & $05 / 11 / 2005$ & $36^{\circ} 19^{\prime} 14^{\prime \prime}$ & $117^{\circ} 31^{\prime} 23^{\prime \prime}$ & male & 062624124 & $06 / 08 / 2005$ & $36^{\circ} 19^{\prime} 18^{\prime \prime}$ & $117^{\circ} 30^{\prime} 57^{\prime \prime}$ & female \\
\hline 054884313 & $05 / 11 / 2005$ & $36^{\circ} 19^{\prime} 14^{\prime \prime}$ & $117^{\circ} 31^{\prime} 23^{\prime \prime}$ & male & 062627333 & $06 / 08 / 2005$ & $36^{\circ} 19^{\prime} 17^{\prime \prime}$ & $117^{\circ} 30^{\prime} 57^{\prime \prime}$ & male \\
\hline 054314531 & $05 / 11 / 2005$ & $36^{\circ} 19^{\prime} 15^{\prime \prime}$ & $117^{\circ} 31^{\prime} 23^{\prime \prime}$ & male & 062619830 & $06 / 08 / 2005$ & $36^{\circ} 19^{\prime} 17^{\prime \prime}$ & $117^{\circ} 30^{\prime} 57^{\prime \prime}$ & male \\
\hline 053883811 & $05 / 11 / 2005$ & $36^{\circ} 19^{\prime} 14^{\prime \prime}$ & $117^{\circ} 31^{\prime} 22^{\prime \prime}$ & female & 062623805 & $06 / 08 / 2005$ & $36^{\circ} 19^{\prime} 17^{\prime \prime}$ & $117^{\circ} 30^{\prime} 57^{\prime \prime}$ & male \\
\hline 054379632 & $05 / 11 / 2005$ & $36^{\circ} 19^{\prime} 14^{\prime \prime}$ & $117^{\circ} 31^{\prime} 22^{\prime \prime}$ & female & 062618842 & $06 / 08 / 2005$ & $36^{\circ} 19^{\prime} 17^{\prime \prime}$ & $117^{\circ} 30^{\prime} 57^{\prime \prime}$ & male \\
\hline 053808267 & $05 / 11 / 2005$ & $36^{\circ} 19^{\prime} 15^{\prime \prime}$ & $117^{\circ} 31^{\prime} 22^{\prime \prime}$ & male & 062619298 & $06 / 08 / 2005$ & $36^{\circ} 19^{\prime} 17^{\prime \prime}$ & $117^{\circ} 30^{\prime} 58^{\prime \prime}$ & male \\
\hline 054588007 & $05 / 11 / 2005$ & $36^{\circ} 19^{\prime} 15^{\prime \prime}$ & $117^{\circ} 31^{\prime} 22^{\prime \prime}$ & male & 062623849 & $06 / 08 / 2005$ & $36^{\circ} 19^{\prime} 16^{\prime \prime}$ & $117^{\circ} 31^{\prime} 01^{\prime \prime}$ & male \\
\hline 054056082 & $05 / 11 / 2005$ & $36^{\circ} 19^{\prime} 15^{\prime \prime}$ & $117^{\circ} 31^{\prime} 22^{\prime \prime}$ & male & 062627323 & $06 / 08 / 2005$ & $36^{\circ} 19^{\prime} 16^{\prime \prime}$ & $117^{\circ} 31^{\prime} 00^{\prime \prime}$ & male \\
\hline 054121832 & $05 / 11 / 2005$ & $36^{\circ} 19^{\prime} 14^{\prime \prime}$ & $117^{\circ} 31^{\prime} 22^{\prime \prime}$ & male & 062605604 & 06/08/2005 & $36^{\circ} 19^{\prime} 16^{\prime \prime}$ & $117^{\circ} 31^{\prime} 00^{\prime \prime}$ & male \\
\hline 055052880 & $05 / 11 / 2005$ & $36^{\circ} 19^{\prime} 15^{\prime \prime}$ & $117^{\circ} 31^{\prime} 22^{\prime \prime}$ & male & 062606257 & $06 / 09 / 2005$ & $36^{\circ} 19^{\prime} 15^{\prime \prime}$ & $117^{\circ} 31^{\prime} 01^{\prime \prime}$ & male \\
\hline 055271776 & $05 / 11 / 2005$ & $36^{\circ} 19^{\prime} 14^{\prime \prime}$ & $117^{\circ} 31^{\prime} 22^{\prime \prime}$ & not checked & 062628792 & $06 / 09 / 2005$ & $36^{\circ} 19^{\prime} 15^{\prime \prime}$ & $117^{\circ} 31^{\prime} 05^{\prime \prime}$ & male \\
\hline 055258871 & $05 / 11 / 2005$ & $36^{\circ} 19^{\prime} 15^{\prime \prime}$ & $117^{\circ} 31^{\prime} 22^{\prime \prime}$ & male & 062605300 & 06/09/2005 & $36^{\circ} 19^{\prime} 15^{\prime \prime}$ & $117^{\circ} 31^{\prime} 05^{\prime \prime}$ & male \\
\hline 054011602 & $05 / 11 / 2005$ & $36^{\circ} 19^{\prime} 14^{\prime \prime}$ & $117^{\circ} 31^{\prime} 22^{\prime \prime}$ & male & 062622567 & 06/09/2005 & $36^{\circ} 19^{\prime} 15^{\prime \prime}$ & $117^{\circ} 31^{\prime} 04^{\prime \prime}$ & male \\
\hline 054323810 & $05 / 11 / 2005$ & $36^{\circ} 19^{\prime} 14^{\prime \prime}$ & $117^{\circ} 31^{\prime} 22^{\prime \prime}$ & male & 062619796 & 06/09/2005 & $36^{\circ} 19^{\prime} 15^{\prime \prime}$ & $117^{\circ} 31^{\prime} 05^{\prime \prime}$ & male \\
\hline 055062597 & $05 / 11 / 2005$ & $36^{\circ} 19^{\prime} 14^{\prime \prime}$ & $117^{\circ} 31^{\prime} 22^{\prime \prime}$ & male & 062622834 & $07 / 07 / 2005$ & $36^{\circ} 19^{\prime} 15^{\prime \prime}$ & $117^{\circ} 31^{\prime} 24^{\prime \prime}$ & male \\
\hline 054029258 & $05 / 11 / 2005$ & $36^{\circ} 19^{\prime} 15^{\prime \prime}$ & $117^{\circ} 31^{\prime} 22^{\prime \prime}$ & male & 062583542 & $07 / 07 / 2005$ & $36^{\circ} 19^{\prime} 15^{\prime \prime}$ & $117^{\circ} 31^{\prime} 24^{\prime \prime}$ & male \\
\hline 053879838 & $05 / 11 / 2005$ & $36^{\circ} 19^{\prime} 15^{\prime \prime}$ & $117^{\circ} 31^{\prime} 22^{\prime \prime}$ & male & 062604573 & $07 / 07 / 2005$ & $36^{\circ} 19^{\prime} 15^{\prime \prime}$ & $117^{\circ} 31^{\prime} 24^{\prime \prime}$ & male \\
\hline 055065860 & $05 / 11 / 2005$ & $36^{\circ} 19^{\prime} 14^{\prime \prime}$ & $117^{\circ} 31^{\prime} 22^{\prime \prime}$ & male & 107630572 & $07 / 07 / 2005$ & $36^{\circ} 19^{\prime} 14^{\prime \prime}$ & $117^{\circ} 31^{\prime} 24^{\prime \prime}$ & male \\
\hline 053860800 & $05 / 11 / 2005$ & $36^{\circ} 19^{\prime} 15^{\prime \prime}$ & $117^{\circ} 31^{\prime} 22^{\prime \prime}$ & male & 107622342 & $07 / 07 / 2005$ & $36^{\circ} 19^{\prime} 14^{\prime \prime}$ & $117^{\circ} 31^{\prime} 24^{\prime \prime}$ & male \\
\hline 053869314 & $06 / 08 / 2005$ & $36^{\circ} 19^{\prime} 26^{\prime \prime}$ & $117^{\circ} 30^{\prime} 56^{\prime \prime}$ & male & 107627515 & $07 / 07 / 2005$ & $36^{\circ} 19^{\prime} 15^{\prime \prime}$ & $117^{\circ} 31^{\prime} 22^{\prime \prime}$ & male \\
\hline 062618782 & $06 / 08 / 2005$ & $36^{\circ} 19^{\prime} 25^{\prime \prime}$ & $117^{\circ} 30^{\prime} 56^{\prime \prime}$ & female & 107627369 & $07 / 07 / 2005$ & $36^{\circ} 19^{\prime} 15^{\prime \prime}$ & $117^{\circ} 31^{\prime} 22^{\prime \prime}$ & male \\
\hline 054571637 & $06 / 08 / 2005$ & $36^{\circ} 19^{\prime} 26^{\prime \prime}$ & $117^{\circ}$ & male & 107780015 & $07 / 07 /$ & $36^{\circ}$ & $117^{\circ} 31^{\prime} 22^{\prime \prime}$ & male \\
\hline 062623830 & $06 / 08 / 2005$ & $36^{\circ} 19^{\prime} 26^{\prime \prime}$ & $117^{\circ} 30^{\prime} 56^{\prime \prime}$ & female & 107610012 & $07 / 07 / 2005$ & $36^{\circ} 19^{\prime} 14^{\prime \prime}$ & $117^{\circ} 31^{\prime} 22^{\prime \prime}$ & male \\
\hline 062623835 & $06 / 08 / 2005$ & $36^{\circ} 19^{\prime} 24^{\prime \prime}$ & $117^{\circ} 30^{\prime} 56^{\prime \prime}$ & female & 107617347 & $07 / 07 / 2005$ & $36^{\circ} 19^{\prime} 14^{\prime \prime}$ & $117^{\circ} 31^{\prime} 22^{\prime \prime}$ & male \\
\hline 062606576 & $06 / 08 / 2005$ & $36^{\circ} 19^{\prime} 24^{\prime \prime}$ & $117^{\circ} 30^{\prime} 56^{\prime \prime}$ & female & 107626290 & $07 / 07 / 2005$ & $36^{\circ} 19^{\prime} 15^{\prime \prime}$ & $117^{\circ} 31^{\prime} 01^{\prime \prime}$ & male \\
\hline 062619278 & $06 / 08 / 2005$ & $36^{\circ} 19^{\prime} 23^{\prime \prime}$ & $117^{\circ} 30^{\prime} 57^{\prime \prime}$ & female & 107638605 & $07 / 07 / 2005$ & $36^{\circ} 19^{\prime} 16^{\prime \prime}$ & $117^{\circ} 31^{\prime} 00^{\prime \prime}$ & male \\
\hline 062626124 & $06 / 08 / 2005$ & $36^{\circ} 19^{\prime} 22^{\prime \prime}$ & $117^{\circ} 30^{\prime} 56^{\prime \prime}$ & female & 107628380 & $07 / 07 / 2005$ & $36^{\circ} 19^{\prime} 15^{\prime \prime}$ & $117^{\circ} 31^{\prime} 00^{\prime \prime}$ & male \\
\hline 062615029 & $06 / 08 / 2005$ & $36^{\circ} 19^{\prime} 22^{\prime \prime}$ & $117^{\circ} 30^{\prime} 57^{\prime \prime}$ & male & 107634099 & $07 / 07 / 2005$ & $36^{\circ} 19^{\prime} 15^{\prime \prime}$ & $117^{\circ} 31^{\prime} 00^{\prime \prime}$ & male \\
\hline 062612849 & $06 / 08 / 2005$ & $36^{\circ} 19^{\prime} 20^{\prime \prime}$ & $117^{\circ} 30^{\prime} 56^{\prime \prime}$ & male & 107608624 & $07 / 08 / 2005$ & $36^{\circ} 19^{\prime} 15^{\prime \prime}$ & $117^{\circ} 31^{\prime} 00^{\prime \prime}$ & male \\
\hline 062604284 & $06 / 08 / 2005$ & $36^{\circ} 19^{\prime} 21^{\prime \prime}$ & $117^{\circ} 30^{\prime} 56^{\prime \prime}$ & male & 107614544 & $07 / 08 / 2005$ & $36^{\circ} 19^{\prime} 16^{\prime \prime}$ & $117^{\circ} 31^{\prime} 00^{\prime \prime}$ & male \\
\hline 062617534 & $06 / 08 / 2005$ & $36^{\circ} 19^{\prime} 21^{\prime \prime}$ & $117^{\circ} 30^{\prime} 56^{\prime \prime}$ & male & 107636123 & $07 / 08 / 2005$ & $36^{\circ} 19^{\prime} 16^{\prime \prime}$ & $117^{\circ} 31^{\prime} 01^{\prime \prime}$ & male \\
\hline 062623809 & $06 / 08 / 2005$ & $36^{\circ} 19^{\prime} 21^{\prime \prime}$ & $117^{\circ} 30^{\prime} 56^{\prime \prime}$ & male & 107613105 & $07 / 08 / 2005$ & $36^{\circ} 19^{\prime} 16^{\prime \prime}$ & $117^{\circ} 30^{\prime} 59^{\prime \prime}$ & male \\
\hline 062612535 & $06 / 08 / 2005$ & $36^{\circ} 19^{\prime} 22^{\prime \prime}$ & $117^{\circ} 30^{\prime} 56^{\prime \prime}$ & female & 107602591 & $07 / 08 / 2005$ & $36^{\circ} 19^{\prime} 17^{\prime \prime}$ & $117^{\circ} 30^{\prime} 57^{\prime \prime}$ & male \\
\hline 062610373 & $06 / 08 / 2005$ & $36^{\circ} 19^{\prime} 22^{\prime \prime}$ & $117^{\circ} 30^{\prime} 56^{\prime \prime}$ & female & 107617121 & $07 / 08 / 2005$ & $36^{\circ} 19^{\prime} 17^{\prime \prime}$ & $117^{\circ} 30^{\prime} 57^{\prime \prime}$ & male \\
\hline 062611117 & $06 / 08 / 2005$ & $36^{\circ} 19^{\prime} 21^{\prime \prime}$ & $117^{\circ} 30^{\prime} 56^{\prime \prime}$ & female & 107625275 & $07 / 08 / 2005$ & $36^{\circ} 19^{\prime} 18^{\prime \prime}$ & $117^{\circ} 30^{\prime} 57^{\prime \prime}$ & male \\
\hline 054570269 & $06 / 08 / 2005$ & $36^{\circ} 19^{\prime} 21^{\prime \prime}$ & $117^{\circ} 30^{\prime} 56^{\prime \prime}$ & male & 107594588 & $07 / 08 / 2005$ & $36^{\circ} 19^{\prime} 19^{\prime \prime}$ & $117^{\circ} 30^{\prime} 56^{\prime \prime}$ & male \\
\hline 062620311 & $06 / 08 / 2005$ & $36^{\circ} 19^{\prime} 20^{\prime \prime}$ & $117^{\circ} 30^{\prime} 56^{\prime \prime}$ & male & 107637087 & $07 / 08 / 2005$ & $36^{\circ} 19^{\prime} 19^{\prime \prime}$ & $117^{\circ} 30^{\prime} 57^{\prime \prime}$ & male \\
\hline 062626044 & 06/08/2005 & $36^{\circ} 19^{\prime} 20^{\prime \prime}$ & $117^{\circ} 30^{\prime} 57^{\prime \prime}$ & male & 107623577 & $07 / 08 / 2005$ & $36^{\circ} 19^{\prime} 19^{\prime \prime}$ & $117^{\circ} 30^{\prime} 56^{\prime \prime}$ & female \\
\hline 062603612 & $06 / 08 / 2005$ & $36^{\circ} 19^{\prime} 20^{\prime \prime}$ & $117^{\circ} 30^{\prime} 57^{\prime \prime}$ & male & 107617599 & $07 / 08 / 2005$ & $36^{\circ} 19^{\prime} 19^{\prime \prime}$ & $117^{\circ} 30^{\prime} 56^{\prime \prime}$ & female \\
\hline 062605041 & $06 / 08 / 2005$ & $36^{\circ} 19^{\prime} 21^{\prime \prime}$ & $117^{\circ} 30^{\prime} 55^{\prime \prime}$ & male & 107627365 & $07 / 08 / 2005$ & $36^{\circ} 19^{\prime} 21^{\prime \prime}$ & $117^{\circ} 30^{\prime} 56^{\prime \prime}$ & female \\
\hline 062605564 & $06 / 08 / 2005$ & $36^{\circ} 19^{\prime} 18^{\prime \prime}$ & $117^{\circ} 30^{\prime} 57^{\prime \prime}$ & female & 107620851 & $07 / 08 / 2005$ & $36^{\circ} 19^{\prime} 21^{\prime \prime}$ & $117^{\circ} 30^{\prime} 56^{\prime \prime}$ & male \\
\hline 054620632 & $06 / 08 / 2005$ & $36^{\circ} 19^{\prime} 19^{\prime \prime}$ & $117^{\circ} 30^{\prime} 57^{\prime \prime}$ & male & 107625605 & $07 / 08 / 2005$ & $36^{\circ} 19^{\prime} 21^{\prime \prime}$ & $117^{\circ} 30^{\prime} 56^{\prime \prime}$ & female \\
\hline
\end{tabular}

062613625

$06 / 08 / 200536^{\circ} 19^{\prime} 19^{\prime \prime}$

$117^{\circ} 30^{\prime} 57^{\prime \prime}$ not checked 
Prepared by the Sacramento Publishing Service Center.

For more information concerning this report, contact:

Director

U.S. Geological Survey

California Water Science Center

6000 J Street, Placer Hall

Sacramento, CA 95819

dc_ca@usgs.gov

or visit our Web site at:

http://ca.water.usgs.gov 


\section{$\frac{\mathbb{2}}{\mathrm{C}}$}

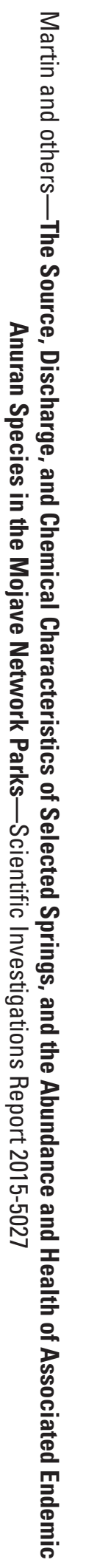

ISSN 2328-031X (online)

http://dx.doi.org/10.3133/SIR20155027 